\title{
WestVirginiaUniversity
}

THE RESEARCH REPOSITORY @ WVU

Graduate Theses, Dissertations, and Problem Reports

2000

\section{Mechanical property characterization of recycled thermoplastics}

Johnny Edward Bargo

West Virginia University

Follow this and additional works at: https://researchrepository.wvu.edu/etd

\section{Recommended Citation}

Bargo, Johnny Edward, "Mechanical property characterization of recycled thermoplastics" (2000). Graduate Theses, Dissertations, and Problem Reports. 998.

https://researchrepository.wvu.edu/etd/998

This Thesis is protected by copyright and/or related rights. It has been brought to you by the The Research Repository @ WVU with permission from the rights-holder(s). You are free to use this Thesis in any way that is permitted by the copyright and related rights legislation that applies to your use. For other uses you must obtain permission from the rights-holder(s) directly, unless additional rights are indicated by a Creative Commons license in the record and/ or on the work itself. This Thesis has been accepted for inclusion in WVU Graduate Theses, Dissertations, and Problem Reports collection by an authorized administrator of The Research Repository @ WVU. For more information, please contact researchrepository@mail.wvu.edu. 


\title{
MECHANICAL PROPERTY CHARACTERIZATION OF RECYCLED THERMOPLASTICS
}

\author{
Johnny E. Bargo \\ Thesis Submitted to the \\ College of Engineering and Mineral Resources \\ at West Virginia University \\ in partial fulfillment of the requirements \\ for the degree of
}

Master of Science

In

Civil Engineering

Dr. Hota Gangarao, Ph.D., Chair

Dr. Rakesh Gupta, Ph.D.

Dr. P.V. Vijay, Ph.D.

Department of Civil and Environmental Engineering

Morgantown, West Virginia

2000

Keywords: Recycled Polymers, ABS, PC, Tension, Compression, Bending, Hardness, Impact, Creep 


\section{ABSTRACT \\ Mechanical Property Characterization of Recycled Thermoplastics}

Johnny E. Bargo

Reuse of engineering thermoplastics retrieved from discarded computers, monitors and printers called as electronic shredder residue is described in the following thesis. Virgin, blend of virgin and recycled, and 100\% recycled polymers such as acrylonitrile butadiene styrene (ABS) and polycarbonate (PC) are characterized for mechanical properties as part of this research. This research consists of characterization of mechanical properties such as tension, bending, compression, impact, hardness, and creep of ABS and PC plastics.

Long-term mechanical property retention and environmental durability are very important for infrastructure and automotive applications. The resins alone do not have the strength or stiffness to meet the requirements of certain automobile or construction applications. Hence, to obtain improved mechanical properties, the polymers in this research are characterized by adding fibers during the manufacturing process.

It was found that the recycled $\mathrm{ABS}$ and PC polymers retain at least $85 \%$ and in some cases over $90 \%$ of the tension, bending, and compression strength and stiffness properties compared to virgin polymers. Based on test results it is concluded that recycled polymers have significant potential for high-volume infrastructure and automotive applications because of a high percent of mechanical property retention under long-term loading conditions. 
This Thesis is dedicated to

My Wife, Heather, and My Parents 


\section{ACKNOWLEDGEMENTS}

I am grateful to my advisor, Dr. Hota GangaRao, for his help and guidance in the preparation of this thesis. He kept me motivated and enabled me to keep focused through the difficult times. I would also like to thank Dr. P.V. Vijay for all his valuable suggestions during this thesis, for without him, it would have been much more difficult to successfully complete this work.

Thanks to Mr. Dana Humberson and Mr. Paul Frum for their guidance in using the laboratory facilities.

A special thanks goes to my parents, Jim and Edith, for their encouragement and love throughout my life. A special thanks also goes to my wife, Heather, for her patience, love, and motivation throughout the course of this work. Without my family, none of this would have been possible.

I would like to acknowledge the Department of Civil and Environmental Engineering, the Constructed Facilities Center, and also the Teledyne Brown Engineering and U.S. DOE/FETC for funding this work and offering me this research assistantship. Thanks to Dr. Carl Irvine of NRCCE, West Virginia University, Dr. Darren Arola of MBA Polymers, Dr. Kwan Hongladarom of GE Plastics, Mr. Bob Schweizer of Owens Corning Company, Mr. Bill Ferrell of PPG, and Mr. Jim Bargo of Reliable Tool Rental for their support during different phases of this research.

Finally, I wish to express my sincere and heartfelt thanks to Bryan King whose friendship was invaluable during the long and difficult process of completing this thesis. 


\section{TABLE OF CONTENTS}

$\begin{array}{lr}\text { ABSTRACT } & \text { ii } \\ \text { ACKNOWLEDGEMENTS } & \text { iv } \\ \text { TABLE OF CONTENTS } & \mathrm{v} \\ \text { LIST OF TABLES } & \text { xi } \\ \text { LIST OF FIGURES } & \text { xiv }\end{array}$

CHAPTER 1 1

INTRODUCTION

$1.1 \quad$ General Remarks 1

$\begin{array}{lll}1.2 & \text { Objectives } & 2\end{array}$

$\begin{array}{lll}1.3 & \text { Scope } & 3\end{array}$

CHAPTER $2+5$

LITERATURE REVIEW

2.1 Introduction 5

$\begin{array}{lll}2.2 & \text { Recycling Issues } & 6\end{array}$

2.2.1 Collection 6

$\begin{array}{lll}2.2 .2 \text { Separation } & 6\end{array}$

$\begin{array}{lll}\text { 2.2.3 Manufacturing } & 9\end{array}$

$\begin{array}{lll}2.2 .4 & \text { Consumption } & 9\end{array}$

2.3 Previous Research with Recycled Plastics 10 
$\begin{array}{lr}\text { CHAPTER } 3 & 14\end{array}$

MATERIALS, MANUFACTURING AND TEST PROCEDURE 14

$\begin{array}{lll}3.1 & \text { Introduction } & 14\end{array}$

$\begin{array}{lll}3.2 & \text { Materials } & 15\end{array}$

$\begin{array}{lll}\text { 3.2.1 Virgin Polymers } & 15\end{array}$

$\begin{array}{ll}\text { 3.2.2 Recycled Polymers } & 16\end{array}$

$\begin{array}{lll}\text { 3.2.3 Glass Fibers } & 16\end{array}$

$\begin{array}{lll}3.3 & \text { Manufacturing } & 17\end{array}$

$\begin{array}{lll}\text { 3.3.1 Injection Molding Process } & 17\end{array}$

$\begin{array}{lll}3.4 & \text { Testing } & 19\end{array}$

$\begin{array}{lll}3.4 .1 & \text { Tension Test } & 19\end{array}$

3.4.1.1 Test Specimen $\quad 19$

$\begin{array}{ll}\text { 3.4.1.2 Specimen Preparation } & 20\end{array}$

3.4.1.3 Test Set-up and Procedure $\quad 20$

$\begin{array}{lll}3.4 .2 & \text { Bending Test } & 22\end{array}$

$\begin{array}{ll}\text { 3.4.2.1 Test Specimen } & 22\end{array}$

3.4.2.2 Specimen Preparation 22

3.4.2.3 Test Set-Up and Procedure 22

$\begin{array}{lll}\text { 3.4.3 Compression Test } & 24\end{array}$

$\begin{array}{ll}\text { 3.4.3.1 Test Specimen } & 24\end{array}$

3.4.3.2 Specimen Preparation 24 
3.4.3.3 Test Set-Up and Procedure

3.4.4 Impact Test

3.4.4.1 Test Specimen

3.4.4.2 Specimen Preparation

3.4.4.3 Test Set-Up and Procedure

27

3.4.5 Creep Test

28

3.4.5.1 Test Specimen 28

3.4.5.2 Specimen Preparation 28

3.4.5.3 Test Set-Up and Procedure 29

3.4.6 Hardness Test 30

3.4.6.1 Test Specimen 30

3.4.6.2 Specimen Preparation 30

3.4.6.3 Test Set-Up and Procedure 30

CHAPTER 4

TEST RESULTS, ANALYSIS, AND DISCUSSIONS

$\begin{array}{lll}4.1 & \text { Introduction } & 31\end{array}$

$\begin{array}{lll}4.2 & \text { Tension Test } & 31\end{array}$

4.2.1 Results of Tension Test on ABS 31

4.2.2 Analysis and Discussion of Tension Test Results on ABS 34

4.2.3 Results of Tension Tests on PC 35

4.2.4 Analysis and Discussion of Tension Test Results on PC 39

$\begin{array}{lll}4.3 & \text { Bending Test } & 40\end{array}$ 
4.3.1 Results of Bending Tests on ABS 40

4.3.2 Analysis and Discussion of Bending Test Results on ABS 43

4.3.3 Results of Bending Tests on PC 44

4.3.4 Analysis and Discussion of Bending Test Results on PC 47

$\begin{array}{lll}4.4 & \text { Compression Test } & 48\end{array}$

4.4.1 Results of Compression Tests on ABS 48

4.4.2 Analysis and Discussion of Compression Test Results on ABS 51

4.4.3 Results of Compression Tests on PC 53

4.4.4 Analysis and Discussion of Compression Test Results on PC 57

$\begin{array}{lll}4.5 & \text { Impact Test } & 58\end{array}$

4.5.1 Results, Analysis, and Discussion of Impact Tests on ABS 58

4.5.2 Results, Analysis, and Discussion of Impact Tests on PC 60

$\begin{array}{lll}\text { 4.6 Hardness Test } & 63\end{array}$

4.6.1 Results, Analysis, and Discussion of Hardness Tests on ABS 63

4.6.2 Results, Analysis, and Discussion of Hardness Tests on PC 66

$\begin{array}{lll}4.7 & \text { Creep Test } & 69\end{array}$

4.7.1 Results, Analysis, and Discussion of Creep Tests on ABS 69

4.7.2 Results, Analysis, and Discussion of Creep Tests on PC 73

$\begin{array}{ll}\text { CHAPTER } 5 & 78\end{array}$

ANALYTICAL COMPARISONS AND EVALUATIONS 78

5.1 Theoretical Analysis and Comparisons of Tension Test Results 78

5.2 Theoretical Equations used in Bending Test Results 81

5.3 Theoretical Analysis of Compression Testing 83 
5.4 Theoretical Analysis of Impact and Hardness Testing 83

$\begin{array}{lll}5.5 & \text { Conclusions } & 84\end{array}$

$\begin{array}{lr}\text { CHAPTER } 6 & 85\end{array}$

SUMMARY, CONCLUSIONS AND RECOMMENDATIONS 85

$\begin{array}{llr}6.1 & \text { Introduction } & 85\end{array}$

$\begin{array}{llr}6.2 & \text { Summary } & 85\end{array}$

6.2.1 Summary of Tension Test Results $\quad 85$

6.2.2 Summary of Bending Test Results $\quad 88$

6.2.3 Summary of Compression Test Results $\quad 90$

6.2.4 Summary of Impact Test Results 92

6.2.5 Summary of Hardness Test Results 94

6.2.6 Summary of Creep Test Results 96

$\begin{array}{lll}6.3 & \text { Conclusions } & 98\end{array}$

$\begin{array}{lll}6.4 & \text { Recommendations } & 102\end{array}$

$\begin{array}{ll}\text { REFERENCES } & 104\end{array}$

APPENDIX A

$\begin{array}{ll}\text { TENSION TEST RESULTS } & 106\end{array}$

APPENDIX B

$\begin{array}{lr}\text { BENDING TEST RESULTS } & 110\end{array}$ 
APPENDIX C

COMPRESSION TEST RESULTS

114

APPENDIX D

IMPACT TEST RESULTS

118

APPENDIX E

HARDNESS TEST RESULTS

122

APPENDIX F

CREEP TEST RESULTS

127 


\section{LIST OF TABLES}

Table 1.1 Samples Tested, Resin Type, and Type of Fibers 4

Table 3.1 Description of Different Types of ABS Specimens 18

Table 3.2 Description of Different Types of PC Specimens 18

Table 3.3 ASTM Coupon Dimension and Test Procedure Specification 19

Table 3.4 Dimensions of Injected Molded Tensile Test Specimen 20

Table 3.5 Dimensions of Impact Test Specimen 27

Table 4.1 Tension Test Results on ABS 32

Table 4.2 Analysis and Comparison of Tension Test Results on ABS

(\% Increase/Decrease) 34

Table 4.3 Tension Test Results on PC 36

Table 4.4 Analysis and Comparison of Tension Test Results on PC

(\% Increase/Decrease) $\quad 39$

Table 4.5 Results of Bending Tests on ABS 41

Table 4.6 Analysis and Comparison of Bending Test Results on ABS

(\% Increase/Decrease)

Table 4.7 Results of Bending Tests on PC

Table 4.8 Analysis and Comparison of Bending Test Results on PC

(\% Increase/Decrease)

Table 4.9 Results of Compression Tests on ABS 49

Table 4.10 Analysis and Comparison of Compression Test Results on ABS

(\% Increase/Decrease) 
Table 4.11 Results of Compression Tests on PC

Table 4.12 Analysis and Comparison of Compression Test Results on PC

(\% Increase/Decrease)

Table 4.13 Results of Impact Tests on ABS

Table 4.14 Analysis and Comparison of Impact Test Results on ABS

(\% Increase/Decrease)

Table 4.15 Results of Impact Tests on PC

Table 4.16 Analysis and Comparison of Impact Test Results on PC

(\% Increase/Decrease)

Table 4.17 Results of Hardness Tests on ABS

Table 4.18 Analysis and Comparison of Hardness Test Results on ABS

(\% Increase/Decrease)

65

Table 4.19 Results of Hardness Tests on PC

66

Table 4.20 Analysis and Comparison of Hardness Test Results on PC

(\% Increase/Decrease)

68

Table 4.21 Creep Data of 145 Days for ABS Specimens with $\approx 50 \%$

Sustained Loading

Table 4.22 Creep Data of 130 Days for ABS Specimens with $\approx 20 \%$

Sustained Loading

Table 4.23 Creep Data of 16 Days for PC Specimens with $\approx 50 \%$

Sustained Loading

Table 4.24 Creep Data of 16 Days for PC Specimens with $\approx 20 \%$

Sustained Loading 
Table 5.1 Determination of Random Modulus, $E_{\text {random }}$

Table 5.2 Analysis and Comparison of $\mathrm{E}_{\text {random }}$ for Theoretical versus

Experimental Results (\% Increase/Decrease) 


\section{LIST OF FIGURES}

Figure 3.1 Tension Specimen Dimensions (Type I,II,III, \& V) 20

$\begin{array}{lll}\text { Figure } 3.2 & \text { Test Set-Up for Tension Test } & 21\end{array}$

$\begin{array}{lll}\text { Figure } 3.3 & \text { Test Set-Up for Extensometer } & 21\end{array}$

$\begin{array}{lll}\text { Figure 3.4 Bending Test of ABS Specimen } & 23\end{array}$

Figure 3.5 Close-up of Bending Test 24

Figure 3.6 Test Set-Up for Compression Test 25

Figure 3.7 Compression Specimen Orientation 26

$\begin{array}{lll}\text { Figure } 3.8 & \text { Impact Test Specimen } & 26\end{array}$

Figure 3.9 BLI Series Impact Testing Machine 27

Figure 3.10 Creep Specimen with Drilled Holes 28

Figure 3.11 Creep Specimen Set-Up Procedure 29

Figure 3.12 Test Set-Up for Creep Test 29

Figure 3.13 Test Set-Up for Hardness Test 30

Figure 4.1 Comparison of Maximum Tensile Stresses in ABS

(12\% Fiber Volume Fraction) $\quad 32$

Figure 4.2 Comparison of Maximum Tensile Stiffness in ABS

(12\% Fiber Volume Fraction)

Figure 4.3 Typical Stress-Strain Curve for Virgin ABS without Fibers

in Tension 33

Figure 4.4 Typical Stress-Strain Curve for Virgin ABS with 12\% Fiber Volume Fraction in Tension 
Figure 4.5 Comparison of Maximum Tensile Stresses in PC

(12\% Fiber Volume Fraction)

Figure 4.6 Comparison of Maximum Tensile Stiffness in PC

(12\% Fiber Volume Fraction)

Figure 4.7 Typical Stress-Strain Curve for Virgin PC without Fibers

in Tension

Figure 4.8 Typical Stress-Strain Curve for Virgin PC with 12\% Fiber

Volume Fraction in Tension

Figure 4.9 Comparison of Maximum Bending Stresses in ABS

(12\% Fiber Volume Fraction)

Figure 4.10 Comparison of Maximum Bending Stiffness in ABS

(12\% Fiber Volume Fraction)

Figure 4.11 Load-Deflection in Bending for ABS Polymer Blend

Specimen without Fibers

Figure 4.12 Load-Deflection in Bending for ABS Polymer Blend

Specimen with 12\% Fiber Volume Fraction

Figure 4.13 Comparison of Maximum Bending Stresses in PC

(12\% Fiber Volume Fraction)

Figure 4.14 Comparison of Maximum Bending Stiffness in PC

(12\% Fiber Volume Fraction)

Figure 4.15 Load-Deflection in Bending for PC Polymer Blend

Specimen without Fibers

46 
Figure 4.16 Load-Deflection in Bending for PC Polymer Blend

Specimen with $12 \%$ Fiber Volume Fraction

Figure 4.17 Comparison of Maximum Compressive Stresses in ABS (12\% Fiber Volume Fraction)

Figure 4.18 Comparison of Maximum Compressive Stiffness in ABS (12\% Fiber Volume Fraction)

Figure 4.19 Stress versus Change-in-Height for 100\% Recycled ABS

Specimen without Fibers in Compression

Figure 4.20 Stress versus Change-in-Height for 100\% Recycled ABS

Specimen with $12 \%$ Fiber Volume Fraction in Compression

Figure 4.21 Deflection gage Set-Up

Figure 4.22 Comparison of Maximum Compressive Stresses in PC (12\% Fiber Volume Fraction)

Figure 4.23 Comparison of Maximum Compressive Stiffness in PC (12\% Fiber Volume Fraction)

Figure 4.24 Stress versus Change-in-Height for 100\% Recycled PC Specimen without Fibers in Compression

Figure 4.25 Stress versus Change-in-Height for 100\% Recycled PC Specimen with 12\% Fiber Volume Fraction in Compression

Figure 4.26 Comparison of Impact Strength in ABS (12\% Fiber Volume Fraction)

Figure 4.27 Comparison of Impact Strength in PC (12\% Fiber Volume Fraction) 
Figure 4.28 Comparison of Hardness Values of ABS w/o Weight

(12\% Fiber Volume Fraction)

Figure 4.29 Comparison of Hardness Values of ABS with 626g Weight

(12\% Fiber Volume Fraction)

Figure 4.30 Comparison of Hardness Values of PC w/o Weight

(12\% Fiber Volume Fraction)

Figure 4.31 Comparison of Hardness Values of PC with 626g Weight

(12\% Fiber Volume Fraction)

Figure 4.32 Creep Curves for ABS with 12\% Fiber Volume Fraction $(\approx 50 \%$ Ultimate Load $)$

Figure 4.33 Creep Curves for ABS without fibers ( $\approx 50 \%$ Ultimate Load)

Figure 4.34 Creep Curves for ABS with 12\% Fiber Volume Fraction $(\approx 20 \%$ Ultimate Load $)$

Figure 4.35 Creep Curves for ABS without fibers ( $\approx 20 \%$ Ultimate Load)

72

Figure 4.36 Creep Curves for PC with 12\% Fiber Volume Fraction $(\approx 50 \%$ Ultimate Load $)$

Figure 4.37 Creep Curves for PC without fibers ( $\approx 50 \%$ Ultimate Load)

Figure 4.38 Creep Curves for PC with 12\% Fiber Volume Fraction ( $\approx 20 \%$ Ultimate Load $)$

Figure 4.39 Creep Curves for PC without fibers ( $\approx 20 \%$ Ultimate Load)

Figure 5.1 Typical P- $\delta$ Plot with Linear Regression 


\section{CHAPTER 1}

\section{INTRODUCTION}

\subsection{General Remarks}

Developing high-volume applications of engineering thermoplastics (acrylonitrile-butadiene styrene, polycarbonate, and others) retrieved from discarded computers, monitors and printers is a major challenge. These thermoplastics may be blended with virgin plastics and elastomers and further reinforced with glass strands or glass fabrics or even glass rods to obtain economical products for high-volume usage.

For example, such fiber-reinforced composites (FRC) may be well suited for highway guardrail posts and guardrails because FRC can be designed for high impact strength because of their good damping properties. Other potential high-volume applications for recycled glass fiber reinforced thermoplastics are pallets and nonstructural window and doorframes. These products can be easily assembled with mechanical and/or adhesive bonding. Similarly, ABS and PC are extensively used for automobile applications such as bumpers, fenders, longitudinal rails, transverse rails, cross members, suspension system components and others made with glass fiber/fabric reinforced thermoplastic composites.

This research consists of characterization of mechanical properties of ABS and PC plastics obtained from computer and monitor housings in three forms, i.e., virgin, blend of virgin and recycled, and 100\% recycled polymers. Long-term mechanical property retention and durability are very important for infrastructure and automotive applications. The resins alone do not have the strength or stiffness to meet the 
requirements of certain automobile or construction applications. Hence, to obtain improved mechanical properties, the polymers in this research are studied by adding fibers during the manufacturing process.

The most common type of fiber used in thermoplastic resin is glass. Glass fibers are available in many different forms such as mats, woven fabrics, rovings, chopped strands, etc. The mechanical and thermal properties of a composite depend on the fiber orientation, quantity, and fiber arrangement. A good understanding of processing composites with glass is essential so that an acceptable product can be obtained. For instance, selecting the correct melt temperature of the resin is a critical step in injection molding process for good finish. In addition, the type of resin and glass fibers must be compatible. Glass fibers need to have appropriate sizing to ensure proper adhesion of glass fibers to the resin. Many other factors such as screw speed, cycle time, injection pressure and drying parameters influence the outcome of a product. All these parameters have to be considered in order to manufacture products with consistent mechanical and structural properties. Hence, industrial quality manufacturing of test samples with and without glass fibers was carried out by CFC-WVU in collaboration with Owens Corning Company and PPG Industries.

\subsection{Objectives}

The main objectives of the research on both virgin and recycled polymers are the following:

- Characterize the strength and stiffness of recycled polymers obtained from electronic shredder residue (ESR) under tension, compression, bending, impact, hardness, and creep. 
- Characterize virgin polymers, which are identical to the ESR polymers, and compare the strength and stiffness of recycled polymers and their blends with virgin polymers under tension, compression, bending, impact, hardness, and creep.

- Establish the impact properties and creep behavior of recycled and virgin polymers and their blends.

\section{$1.3 \quad$ Scope}

There are two main types of polymers, i.e. thermoplastics and thermosets. Thermosets such as polyurethane, polyester, and polyvinyl acetate are usually more brittle than thermoplastics and will not be dealt with in this research. Among the different types of thermoplastics, this research will be limited to polycarbonate (PC) and acrylonitrile-butadiene styrene (ABS).

Recycled ABS and PC were considered for evaluation purposes based on their availability, suitability for mass production and cost. Over 180 ABS samples manufactured by Owens Corning and over 180 PC specimens manufactured by PPG Industries were tested. Table 1.1 shows the type of test conducted and the number of samples tested for each along with the types of resins and fibers used in each sample. Additional information about the specimens, resins and fibers used in the testing is discussed in chapter 3. This report focuses on the results of both the ABS and PC specimens. Material selection, results of different tests and conclusions are provided in chapters 3,4 , and 6 . 


\begin{tabular}{|c|c|c|c|c|c|c|c|c|c|c|}
\hline \multirow{3}{*}{ Test } & \multicolumn{4}{|c|}{ Number of Test Samples } & \multicolumn{4}{|c|}{ Type of Resin } & \multirow{2}{*}{\multicolumn{2}{|c|}{$\begin{array}{c}\text { Type of Chopped } \\
\text { Fibers }\end{array}$}} \\
\hline & \multicolumn{2}{|c|}{ With Fibers } & \multicolumn{2}{|c|}{$\begin{array}{l}\text { Without } \\
\text { Fibers }\end{array}$} & \multicolumn{2}{|c|}{ With Fibers } & \multicolumn{2}{|c|}{$\begin{array}{l}\text { Without } \\
\text { Fibers }\end{array}$} & & \\
\hline & ABS & $\mathrm{PC}$ & ABS & $\mathrm{PC}$ & ABS & $\mathrm{PC}$ & $\mathrm{ABS}$ & $\mathrm{PC}$ & ABS & $\mathrm{PC}$ \\
\hline Tension & 16 & 16 & 15 & 15 & \multirow{6}{*}{\multicolumn{4}{|c|}{$\begin{array}{l}100 \% \text { Virgin } \\
100 \% \text { Recycled } \\
6 \text { Virgin } 20 \% \text { Recycled }\end{array}$}} & \multirow{6}{*}{$\begin{array}{c}4 \mathrm{~mm} \\
14 \mu\end{array}$} & \multirow{6}{*}{$\begin{array}{c}3.18 \mathrm{~mm} \\
13 \mu\end{array}$} \\
\hline Bending & 16 & 15 & 17 & 15 & & & & & & \\
\hline Compression & 20 & 19 & 15 & 16 & & & & & & \\
\hline Impact & 15 & 15 & 15 & 18 & & & & & & \\
\hline Hardness & 48 & 48 & 48 & 48 & & & & & & \\
\hline Creep & 7 & 6 & 8 & 6 & & & & & & \\
\hline
\end{tabular}

Table 1.1 Samples Tested, Resin Type, and Type of Fibers 


\section{CHAPTER 2}

\section{LITERATURE REVIEW}

\subsection{Introduction}

The need for developing suitable methods to recycle and reuse plastic products that are to compete economically with those of virgin polymers is becoming more and more evident. In 1990, an estimated $0.8 \%$ of the nearly 31 million tons of plastics consumed in the United States were recycled, leaving approximately 30.7 million tons finding their way into landfills (Powelson et al., 1992). It is also known that plastics are non-biodegradable (will not decompose naturally when in contact with soil, water and light over a period of time) and will remain in a landfill. The benefits of recycling plastic are:

- the reduction in landfill space requirements

- reduce air pollution from incineration emissions

- reduction in the amount of non-renewable resources needed to manufacture virgin materials (Tall et al., 1998).

On the other hand, there are several trends that are discouraging the mechanical recycling of plastics. The cost of virgin plastics is currently low, and lesser amounts of raw materials are needed for manufacturing due to the sophistication of newer machinery. This in turn promotes the use of mass produced virgin plastics and makes it more difficult for recycled material to compete economically with the virgin plastics (Tall et al. 1998). However, due to growing environmental concerns by both the public and the 
government, research is being carried out to develop various recycled plastics that would closely match the mechanical and thermal properties of virgin plastics.

\subsection{Recycling issues}

In order to establish an acceptable way to recycle materials four main areas must be explored. They are:

- collection

- separation

- manufacturing

- consumption

These areas are briefly described in the following sections, 2.2.1 through 2.2.4.

\subsubsection{Collection}

The collection process is the most important step in recycling, without proper collection of post-consumer waste the recycling process would be much more difficult. In 1990, over 3,000 curbside recycling programs existed in communities across the United States (Powelson et al., 1992). By 1998 the number of community recycling programs, including collection, had risen sharply. In addition to community recycling programs, many businesses have adopted recycling programs to be used by their

employees. Additional means of collecting recyclable products can be found in schools, parks, and government agencies.

\subsubsection{Separation}

Once the collection process is completed, the various materials must now be separated. There are several methods in which this process is completed, often times 
incorporating several separation techniques. It must be pointed out that none of the following techniques is $100 \%$ effective.

In Europe and other developed countries, nearly $75 \%$ of a vehicle's total weight is recycled through a well-established dismantling operation. After the vehicle has been dismantled, $8 \%$ of the post-use plastics waste is currently being recycled with the Association of Plastics Manufacturers in Europe (APME) estimating that the number could rise to as much as 10\% (Modern Plastics, Jan. 2000).

\section{Separation techniques}

1. Magnetic separator - Magnetic separation is a technique where the ferrous material is recovered from the waste stream using three configurations. These are as follows:

- the drum

- the magnetic belt

- the magnetic head pulley.

Feeding the waste stream, by means of a non-metallic conveyor system, near the magnets completes the process. The magnets will then lift the ferrous materials from the waste bed thus allowing the remaining nonferrous materials to pass. The effectiveness of the entire process depends upon bed depth and magnet strength (Swartzbaugh et al. 1993).

2. Eddy current device - This separation technique is designed specifically for aluminum materials. The process works by creating a magnetic field that ejects aluminum products (usually cans) from the waste stream into a collection container. 
3. Disc screen - a disc screen is composed of parallel multiple shafts with discs mounted onto these shafts and spaced in such a manner that the discs on one shaft are midway between the discs on another shaft. This configuration allows smaller material (e.g., broken glass) to fall between the openings of the two shafts and lager material to continue through the separation process (Swartzbaugh et al. 1993).

4. Trommel screen - A Trommel screen is a large cylindrical perforated screen usually with a downward inclination. The waste stream is brought into the trommel by means of a conveyor belt. Once inside, the Trommel screen rotates, thus causing smaller particles to fall through the perforated openings in the screen and out of the waste stream (Swartzbaugh et al. 1993). A more effective configuration is to have two or more trommel screens in-line each with increasingly lager perforations. This would allow for faster separation of materials.

5. Vibrating screen - This technique incorporates a wire mesh or perforated plate screen that is vibrated in order to separate certain size materials from the waste stream.

6. Oscillating screen - The oscillating screen is much like the vibrating screen except that the screens motion is orbital rather than vibrating in plane.

7. Traveling chain curtain - A traveling chain curtain consists of a curtain made from common chain that is suspended from a revolving conveyor. The curtain provides a barrier that allows more dense material to pass while preventing less dense material (e.g., plastic and paper) from continuing through the waste stream. The less dense material is then collected from the curtain as it is directed to the side.

8. Air classifier - The air classifier uses an air stream that is directed upwards through a shaft. The waste stream is brought into the shaft by means of a conveyor and 
then falls through the air stream. The lighter material (e.g., paper and plastic) is blown up through the shaft into a collection container while the heavier material (e.g., metals and glass) falls onto a conveyor at the bottom of the shaft for further separation (Swartzbaugh et al. 1993).

\subsubsection{Manufacturing}

In order to make recycling effective, manufactures must be willing to use comparable recycled materials over virgin materials. Throughout the 1990's, manufactures have become more aware of the increasing need to recycle and their role in the recycling industry. Companies such as Great White (laser printer and copier paper) and Procter \& Gamble (plastic containers) are now using recycled materials over virgin materials in many of their products. As stated earlier, European automobile manufactures are currently recycling nearly $75 \%$ of a vehicles total weight of which $8 \%$ is post-use plastics, which enables product manufactures to have the recycled material needed in order to produce post consumer products like bottles and serving trays. Studies are being conducted by companies such as General Motors that will provide manufactures with the needed mechanical information about recycled products that will allow them to expand their production into the automotive and infrastructure industries.

\subsubsection{Consumption}

To achieve all the benefits that recycling has to offer, consumers must be willing to buy a product that has been manufactured from recycled materials. To stimulate consumption of recycled products, many government agencies and businesses give preference to recycled materials when making purchasing decisions (Powelson et al., 1992). Laws requiring the purchase of recycled materials are also on the rise. 
Connecticut was one of the first states to enact a law targeted at the newspaper industry that required a specific percentage of their annual purchases to be recycled products (Powelson et al., 1992). The manufacturing industry is also assisting consumers in purchasing recycled products by placing symbols on their products to help identify them.

\subsection{Previous research with recycled polymers}

Liang (1999) conducted a literature search on the Recycling of Polymers and evaluated many different types of plastic waste and the recycling methods used in the recovery of the recycled resins.

High-density polyethylene (HDPE) was recycled from milk bottles and tested as a possible food packaging material. Untreated caustic-washed and caustic-washed/stemstripped/air-dried recycled bottles were used in the tests. The untreated caustic-washed recycled material was found to be unsuitable as food packaging due to the high migration rate of some compounds. The steam-stripped recycled material was found to perform identical to the virgin material and could not be distinguished from such. Additional tests concluded that the mechanical properties of the recycled material remained unchanged during the recycling process (Liang, 1999).

Bottles made of polyvinyl chloride (PVC) and supermarket tray material made of pulverized PVC were recycled. Both the recycled materials were combined and coextruded to produce cladding for the building industry. From experiments, it was found that the impact properties of the recycled plastic blend were actually superior to the virgin material due to the presence of high levels of an impact modifier in the original tray formations. Furthermore, using up to $100 \%$ recycled PVC bottles did not affect the impact properties of the extruded product (Liang, 1999). 
It is often difficult to recycle a material that will exhibit the purity of that of a virgin material. Tall et al. (1998), in the article entitled "Improvements in the Properties of Mechanically Recycled Thermoplastics", described the mechanical properties of some thermoplastics, i.e. HDPE, ABS, and ABS/PC blends, when contamination occurred during the recycling process (Tall et al., 1998).

During the recycling process, nearly all polymer mixtures will form separate phases. By forming these separate phases, a blend will usually become more brittle than that of a single-phase material. Tall et al. (1999) studied the effects on impact resistance of a mixture of ABS (acrylonitrile-butadiene styrene) and PC (polycarbonate). Because $\mathrm{ABS}$ and $\mathrm{PC}$ are such common engineering materials, it was probable that these two thermoplastics could be recycled as one blend. However, when recycled together, ABS and PC form separate phases and therefore the blend ratio must be controlled. In order to avoid the minimum impact resistance, it was concluded that a blend ratio of around $30 \%$ PC was to be avoided (Tall et al, 1999).

The effects on the mechanical properties and processing temperatures of various blends of high-density polyethylene (HDPE) with other thermoplastics were also discussed in the article by Tall et al. (1999). A general purpose extrusion grade (melt flow rate $=3.2 \mathrm{dg} / \mathrm{min} @ 230^{\circ} \mathrm{C} / 2.16 \mathrm{~kg}$ ) polypropylene (PP) was blended with HDPE in order to test the effects on both the tensile strength and the tear propagation resistance of the blended material. It was concluded that the tensile strength of the material increased while the tear propagation resistance decreased with increased PP content. Additional tests were conducted with an injection-molding grade (melt flow rate $=18 \mathrm{dg} / \mathrm{min}$ @ $230^{\circ} \mathrm{C} / 2.16 \mathrm{~kg}$ ) polypropylene (PP) blended with HDPE. The conclusions were that 
both the tensile strength and the tear propagation resistance decreased with an increase in PP content and that the blend became very brittle when $30 \%$ PP-content was achieved.

Tall et al. (1999) also discussed how tensile properties were effected for blends of ABS (Ronfalin SRA36) with polypropylene (ME 210 U) and ABS with high-impact polystyrene (Polystyrene 552). The article found that ABS would shift from a ductile mode of failure to a brittle mode of failure at a contamination level of $6 \%$ polypropylene. For the ABS/HIPS blends, it was concluded that at a $4 \%$ HIPS-content, there were significant increases in elongation at break. However, at increasing HIPS-content, the amount of elongation would begin to decrease. For each of the tests, the tensile properties for $100 \%$ ABS was used as a standard.

The effects on the mechanical properties of continuous recycling thermoplastics is of great concern. Eriksson et al. (1997) discusses the effects on the tensile properties of continuous recycling $30 \mathrm{wt} \%$ glass-fiber reinforced polyamide 66 . The study shows that with increasing molding operations, up to four to five, the specimens showed a faster deterioration rate in elongation at break. Furthermore, the onset of embrittlement and a decrease in tensile elongation at break became more evident with increasing molding operations.

In 1996, Norm Kakarala became the team leader of a group faced with the challenge of developing the first $100 \%$ recycled instrument panel for the 2000 Pontiac Boneville. The team was successful and in 1999 the program received the "Recycler of the Year" award from the Society of Plastics Engineers. The process uses $60 \%$ vacuum forming scrap for the interior layer, while the top layer is a virgin plastic so that color consistency and texture can be achieved. One of the most important aspects of the 
application is that it eliminates solvent emissions by using water-borne coatings. The method also ensures grain retention, soft touch and deep draw (Modern Plastics, Jan. 2000).

\subsection{Conclusions}

From the above research work on virgin and recycled polymers, we can conclude that recycled polymers can be used for many applications with little or no effect on the mechanical properties necessary to achieve an acceptable product. In order to achieve the mechanical properties needed for a particular product, the way that recycled plastics are separated and processed is essential. Once recycled polymers have been processed they can then be used with virgin polymers in order to achieve color and texture consistency. 


\section{CHAPTER 3}

\section{MATERIALS, MANUFACTURING AND TEST PROCEDURE}

\subsection{Introduction}

The mechanical properties (i.e. stiffness, strength, etc.) of thermoplastics are not of great concern when used in such products as computer housings or food service trays. However, in order to be a competitive value-added product in the construction or automotive industry, accurate and consistent evaluation of mechanical properties becomes much more relevant. The resins alone often times do not have the strength or stiffness needed for certain automobile or construction applications. Therefore, to gain higher mechanical properties, the resins are combined with fibers during the manufacturing process.

The most common type of fiber used in thermoplastic resin is based on glass. Glass fibers can be purchased in many different forms such as mats, woven or stitched fabrics, rovings, chopped strands, etc. The mechanical and thermal properties of a composite depend on the fiber orientation, quantity (i.e. volume percent in a composite), and fiber arrangement.

During the manufacturing of a composite, a good understanding of processing composites with glass is essential so that an acceptable product can be obtained. For instance, for the injection molding process, selecting the correct melt temperature of the resin is a critical step in producing a good final product. Also, the type of resin used must be compatible with the fibers. Therefore, selecting an appropriate sizing that will ensure proper adhesion of glass fibers to the resin is essential. Many other factors influence the 
outcome of a product such as screw speed, cycle time, injection pressure and drying parameters, all of which are to be understood properly to manufacture high quality products with consistent mechanical and structural properties.

\subsection{Materials}

\subsubsection{Virgin Polymers}

Two types of thermoplastic resins were evaluated in this research: Lexan-101 polycarbonate (PC) and Cycolac-GPM5500 acrylonitrile-butadiene-styrene (ABS) manufactured by GE Plastics Company. Selection of these resins was based on availability of these materials as electronic shredder residue and their commercial viability for infrastructure and automobile applications.

Lexan-101 polycarbonate resins have good electrical, optical, thermal, and mechanical properties including durability. The combination of these physical properties makes it one of the toughest, most versatile of all engineering thermoplastics (GE Plastics, 1999). Lexan-101 resins are widely used in packaging, electronics, appliance and the automotive industries. Lexan-101 resins are available in different commercial grades to suit a wide range of requirements and applications such as flame resistance, wear resistance, and health care use.

Cycolac-GPM5500 ABS resins have excellent impact strength, hardness, rigidity, and toughness properties. The resin grades of Cycolac ABS consist of elastomeric blends of polybutadiene or a butadiene copolymer and an amorphous thermoplastic component of styrene and acrylonitrile (SAN) and are easy to process (GE Plastics 1999). Various other grades of ABS-Cycolac resins are commercially used to meet specific end-product requirements. 


\subsubsection{Recycled Polymers}

Recycled polymers were received from sources such as computer, monitor and printer housings. These were made available to the CFC-WVU research team by the MBA polymers. The recycled polymers were granulated with a size of about 0.25 " or less. Purity of these recycled polymers was well above $90 \%$.

\subsubsection{Glass Fibers}

The chopped glass fibers available from Owens Corning were chosen in this research with suitable sizings compatible with ABS. The 408A-14C CRATEC chopped strands with a length of $4 \mathrm{~mm}$ and diameter of $14 \mu$ used in this study are general-purpose glass fiber reinforcement and have proven compatibility with many thermoplastic resins including ABS. The 408A CRATEC strands are produced at ISO 9002 registered glass fiber facilities. The chopped strands are manufactured from continuous glass filaments that have been gathered into a single bundle. The fiber bundles are then chopped into specific lengths, dried, screened, trace metals removed, and supplied for use. The characteristics of the 408A CRATEC strands include optimized strand integrity, good glass dispersion, excellent mechanical properties, and excellent coupling with polymer systems.

The chopped glass fibers available from PPG were chosen in this research with suitable sizing compatible with PC. The $37623 \mathrm{~mm}$ MaxiChop ${ }^{\circledR}$ chopped strands are general-purpose glass reinforcement and have been proven compatible with both thermoplastic and thermoset resin including PC. The 3762 MaxiChop ${ }^{\circledR}$ E-glass fibers are chopped strands from $3 \mathrm{~mm}(1 / 8$ in) to $13 \mathrm{~mm}$ (1/2 in) in length and $13 \mu$ in diameter. 
The fibers are produced by collimating the continuous fibers into strands and either chopping directly under the bushing, or winding the strands into an intermediate package for subsequent chopping in a separate operation. Proprietary silane-based finishes are applied to the surface of each fiber in order to enable processing and handling and maximize the glass-to-resin bond in the molded part.

\subsection{Manufacturing}

The choice of manufacturing process depends mainly on the type of fibers and resin, temperature required to form the part and cure the resin, and the cost effectiveness of the process involved. The injection molding process was used in the production of test specimens. A brief description of the different types of moldings carried out and the injection molding process is given below.

\subsubsection{Injection Molding Process}

Injection molding of the ABS samples was performed by Owens Corning. Six types of specimens, as described in Table 3.1, were manufactured by Owens Corning. Proper drying of the pellets was necessary before the molding process begins. Standard drying specifications for general-purpose GPM5500 ABS resin is 2-4 hours drying time at a temperature of $180-200^{\circ} \mathrm{F}$. Resins in the form of pellets are uniformly blended by means of a screw extruder. Screws with L/D ratios of 24:1 were used (with a compression ratio of 3.75:1) because shorter screws can sacrifice melt homogeneity and lead to material degradation and discoloration at transition sections (GE Plastics 1999). The melt temperature used for both the extrusion process and the injection molding was $530^{\circ}$ to $535^{\circ} \mathrm{F}$. Molding was performed on a Cincinnati Milacron injection-molding machine with a 200 -ton press. 
Injection molding of the PC samples was performed by PPG. Six types of specimens, as shown in Table 3.2, were manufactured by PPG. Drying time of the Lexan 101 resin was 5 hours at $200^{\circ} \mathrm{F}$. A melt temperature of $300^{\circ}$ to $313^{\circ} \mathrm{F}$ was used for the extrusion process and a melt temperature of $595^{\circ} \mathrm{F}$ during the molding process. The injection screw speed was set at $3.65 \mathrm{H} / \mathrm{sec}$. with a back pressure of $100 \mathrm{psi}$.

Table 3.1 Description of Different Types of ABS Specimens

\begin{tabular}{|c|l|}
\hline Specimens & \multicolumn{1}{|c|}{ Description of Different Specimens } \\
\hline A1 & Virgin ABS polymer without fibers \\
\hline A2 & Virgin ABS polymer with 25\% (wt. \%) chopped fibers \\
\hline A3 & $100 \%$ recycled ABS polymer without fibers \\
\hline A4 & $100 \%$ recycled ABS polymer with 25\% (wt. \%) chopped fibers \\
\hline A5 & Recycled ABS/virgin ABS (20\%/80\%) blend without fibers \\
\hline A6 & Recycled ABS/virgin ABS (20\%/80\%) blend with 25\% (wt. \%) fibers \\
\hline
\end{tabular}

Table 3.2 Description of Different Types of PC Specimens

\begin{tabular}{|c|l|}
\hline Specimens & \multicolumn{1}{|c|}{ Description of Different Specimens } \\
\hline P1 & Virgin PC polymer without fibers \\
\hline P2 & Virgin PC polymer with 25\% (wt. \%) chopped fibers \\
\hline P3 & $100 \%$ recycled PC polymer without fibers \\
\hline P4 & $100 \%$ recycled PC polymer with 25\% (wt. \%) chopped fibers \\
\hline P5 & Recycled PC/virgin PC (20\%/80\%) blend without fibers \\
\hline P6 & Recycled PC/virgin PC (20\%/80\%) blend with 25\% (wt. \%) fibers \\
\hline
\end{tabular}

Coupon specimens manufactured through injection molding allowed the researchers to conduct six types of tests, i.e., tension, compression, bending, impact, hardness and creep. All ABS and PC specimens with fibers contained a fiber volume fraction of $12 \%$. Dimensions of the coupon specimens and test procedures according to ASTM standards are listed in Table 3.3. 
Table 3.3 ASTM Coupon Dimension and Test Procedure Specification

\begin{tabular}{|c|c|}
\hline Specimens & Description of Different Specimens \\
\hline Tension & ASTM D638-94b \\
\hline Bending & ASTM D790-92 \\
\hline Compression & ASTM D695-91 \\
\hline Impact & ASTM D256-93a \\
\hline Durometer Hardness & ASTM D2240-91 \\
\hline Creep & $\begin{array}{c}\text { Sustained load application on modified } \\
\text { tension coupons }\end{array}$ \\
\hline
\end{tabular}

\subsection{Testing}

Details of the test specimen, specimen preparation, test set-up, test procedure, test results and discussions for each type of test are provided in the following sections.

\subsubsection{Tension Test}

\subsubsection{Test Specimen}

The tension test specimens were manufactured to the dimensions as per ASTM D638-94b for a Type I specimen. Figure 3.1 and Table 3.4 show the typical design parameters of a Type I, II, III, \& V tension specimen. Type I and II specimens have a thickness less than 0.28" and fall within the guidelines set by the ASTM standard. For a Type III specimen, the thickness must be between 0.28 " to 0.55 " along with other guidelines set by ASTM. Types IV and V specimens are special cases. A Type IV specimen must have a thickness of 0.16 " or less and a narrow section (W) width of 0.25". Type V specimens must have a thickness of 0.16 " or less and be machined or die cut according to the dimensions set by the ASTM standard. Each specimen was labeled according to the type of test conducted and the test number. For example, a specimen 
designated as TA1-2 represents, tension test $(\mathrm{T})$, sample group (A1 - 100\% virgin sample without fibers), and the test number 2 .

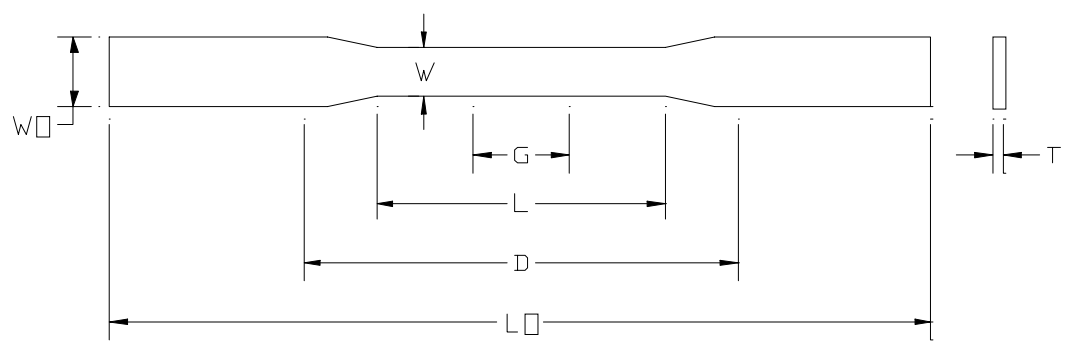

Fig. 3.1 Tension Specimen Dimensions (Types I, II, III, \& V)

Table 3.4 Dimensions of Injection Molded Tensile Test Specimens

\begin{tabular}{|c|c|c|}
\hline Dimensions (see Fig. 3.1) & ABS Specimens & PC Specimens \\
\hline W-Width of narrow section & $0.5^{\prime \prime}$ & $0.5^{\prime \prime}$ \\
\hline L-Length of narrow section & $3.0^{\prime \prime}$ & $3.0^{\prime \prime}$ \\
\hline WO-Width over-all & $0.75^{\prime \prime}$ & $0.75^{\prime \prime}$ \\
\hline LO-Length over-all & $8.5^{\prime \prime}$ & $8.5^{\prime \prime}$ \\
\hline G-Gage length & $1.0^{\prime \prime}$ & $1.0^{\prime \prime}$ \\
\hline D-Distance between grips & $4.5^{\prime \prime}$ & $4.5^{\prime \prime}$ \\
\hline T-Thickness & $0.125^{\prime \prime}$ & $0.125^{\prime \prime}$ \\
\hline
\end{tabular}

\subsubsection{Specimen Preparation}

A series 2620 dynamic strain gage extensometer was used at the midsection as shown in Fig. 3.3 to measure tensile strains. Each of the samples was marked with a permanent marker so that the correct grip location and extensometer position could be easily obtained.

\subsubsection{Test Set-up and Procedure}

Each of the tension specimens was tested using an Instron Series 8500 TwoColumn Load Frame as per ASTM D638-94b as shown in Figure 3.2. The strains were 
automatically recorded using 'wavemaker' software and with the use of extensometer having a gage length of one inch. The extensometer was attached to the tensile specimen by means of rubber bands supplied by the manufacture as shown in Figure 3.3. The tests were computer controlled using the same 'wavemaker' software and loaded to failure at a rate of $300 \mathrm{lbs} . / \mathrm{min}$. Other parameters recorded by the computer were time and displacement.

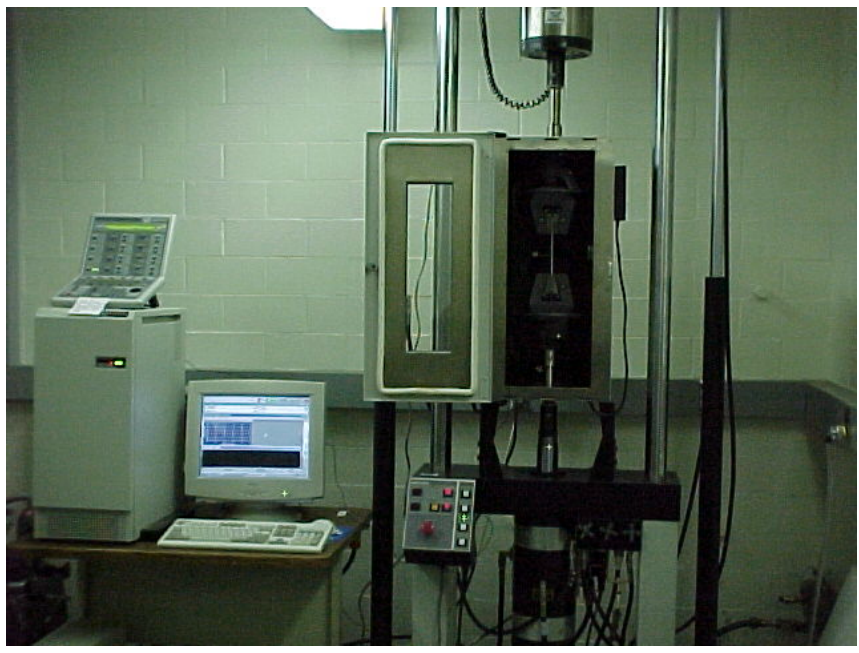

Figure 3.2 Test Set-Up for Tension Test

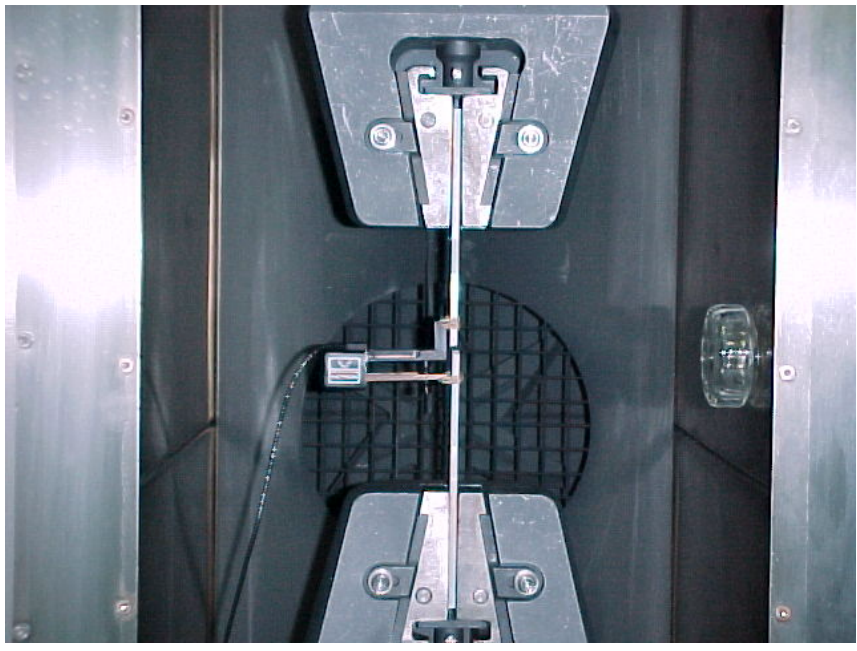

Figure 3.3 Test Set-Up for Extensometer 


\subsubsection{Bending Test}

\subsubsection{Test Specimen}

Bending specimens were manufactured with the dimensions conforming to ASTM D790-92 for a three point bending test. The ABS and PC samples were rectangular in cross section with a length of 5", width of $0.5 "$, and a thickness of $0.125 "$. Each specimen was labeled according to the type of test conducted and the test number. For example, a specimen designated as BA1-14 represents, bending test (B), sample group (A1 - 100\% virgin sample without fibers), and the test number 14. Test span of 3.75" was used for the bending tests.

\subsubsection{Specimen Preparation}

Each of the bending samples was marked with a permanent marker to locate the correct support points. The specimen surface at mid-length was prepared for strain gage application using a 320 grit sandpaper. A degreaser, an acidic surface cleaner followed by a water-based alkaline cleaner was used to remove any oil residues and to aid in the adhesion of the strain gage. Strain gages were then applied using M-Bond 200 adhesive, clamped, and allowed to cure overnight in order to achieve proper bond between the gage and the specimen surface. Gages were bonded at the center on both sides of the specimen to facilitate comparison of stiffnesses in bending or compression as well as tension faces.

\subsubsection{Test Set-up and Procedure}

Each of the bending specimens was tested using an Instron Series 8500 TwoColumn Load Frame or the Instron Model 4411 as per ASTM D790-92. The rate of cross-head motion was set at 0.25 in./min. in accordance with the ASTM standard. ASTM Test Method I, threepoint bending, was performed on each specimen shown in 
Figs. 3.4 and 3.5. The strain gage on the compression side of the test specimen was protected by placing a rubber cushion, with an indentation to match the gage size, on top of the strain gage during loading. Tensile and compressive strains were recorded, using a strain indicator, at predetermined intervals during the test. The specimens were loaded to failure or until significant deflections in excess of $1 / 3$ of the span were observed. Maximum load, displacement and strain values were recorded.

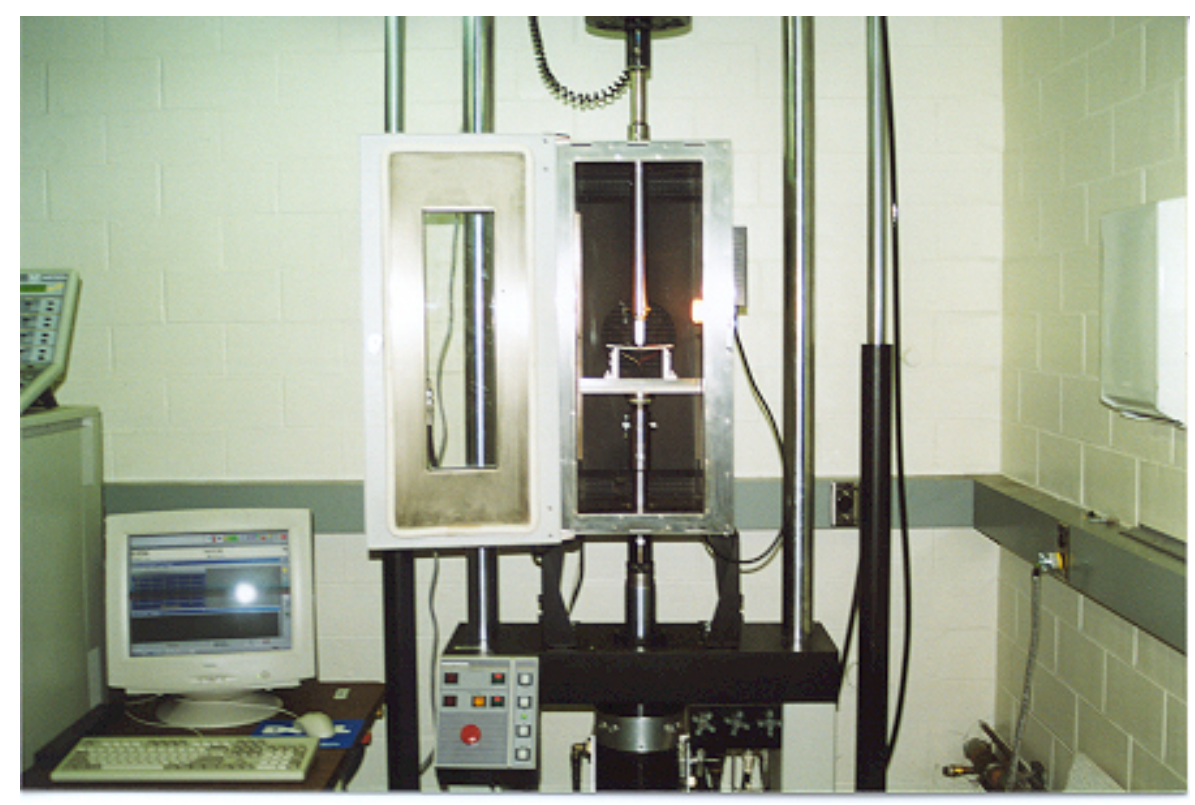

Fig. 3.4 Bending Test of ABS Specimens 


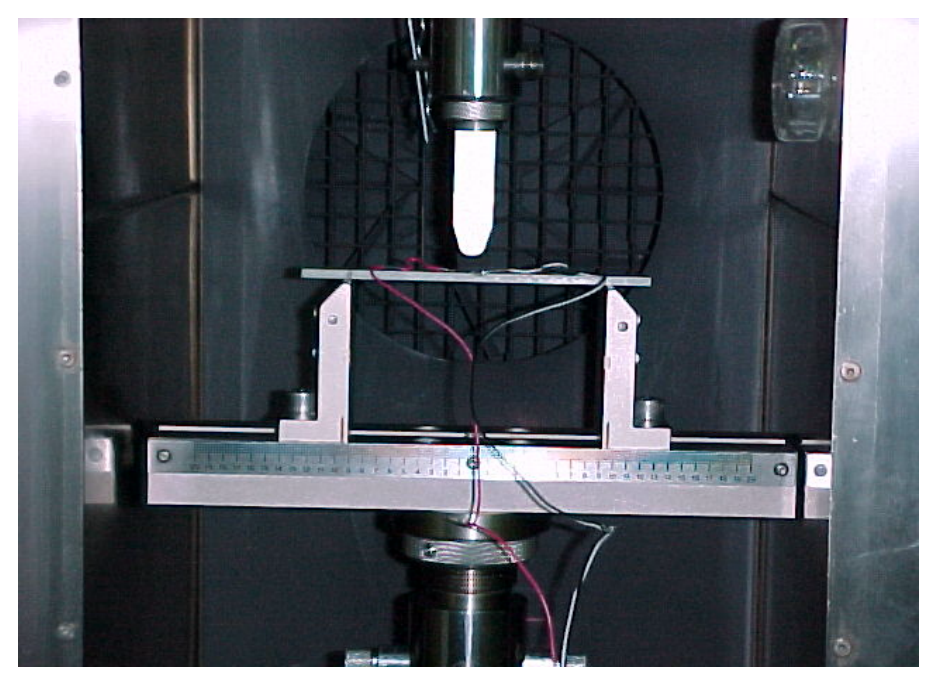

Figure 3.5 Close-up of Bending Test

\subsubsection{Compression Test}

\subsubsection{Test Specimen}

The compression specimens were manufactured to the dimensions as per ASTM standards D695-91. The ABS and PC samples were rectangular with a cross-section of $0.5 " x 0.25 "$. Height of the specimens was $0.5 "$. Additional samples with height $1 "$ and 1.5" were also tested to establish the optimum height for minimizing and eliminating bending effects. Based on pilot testing, height of 0.5 " was chosen, which provides an aspect ratio of 2. Each specimen was labeled according to the type of test conducted and the test number. For example, a specimen designated as CA1-2 represents, compression test (C), sample group (A1 - 100\% virgin sample without fibers), and the test number 2 .

\subsubsection{Specimen Preparation}

Surface of the specimens was prepared for strain gage bonding. The surface preparation and strain gage application were same as described under bending test. 


\subsubsection{Test Set-up and Procedure}

Compression testing was performed using an Instron 8500 Two-Column Load Frame as per ASTM D695-91. Rate of cross-head motion was computer controlled using the Wavemaker software provided by Instron and set at $0.05 \mathrm{in} . / \mathrm{min}$. in accordance with the ASTM standard. The strain was recorded at predetermined intervals during the test using a strain indicator. Each specimen was loaded to maximum load and through the yield zone. Maximum load, strain and reduction in length were recorded. The test set-up and specimen orientation are shown in Figs. 3.6 and 3.7.

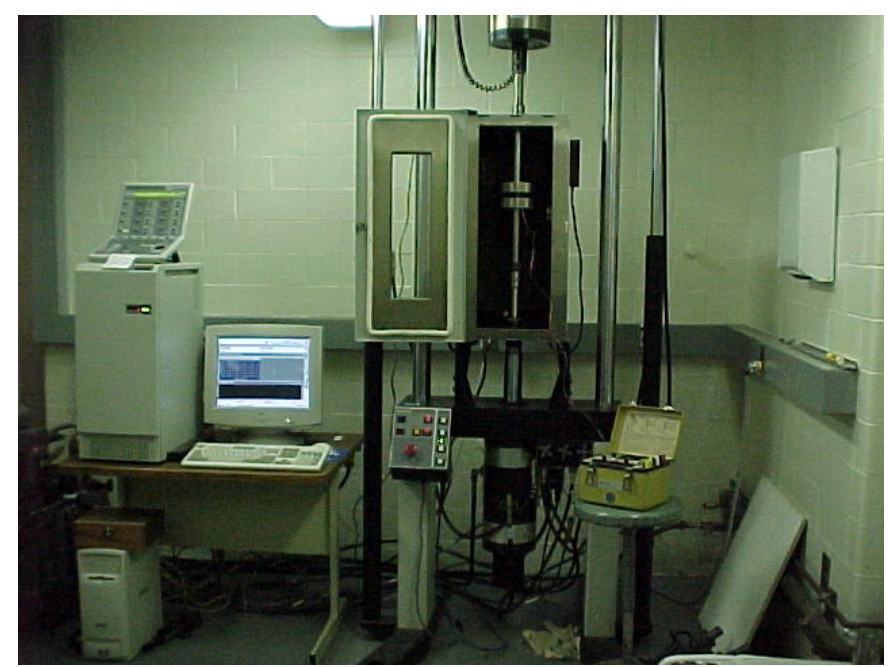

Figure 3.6 Test Set-Up for Compression Test 


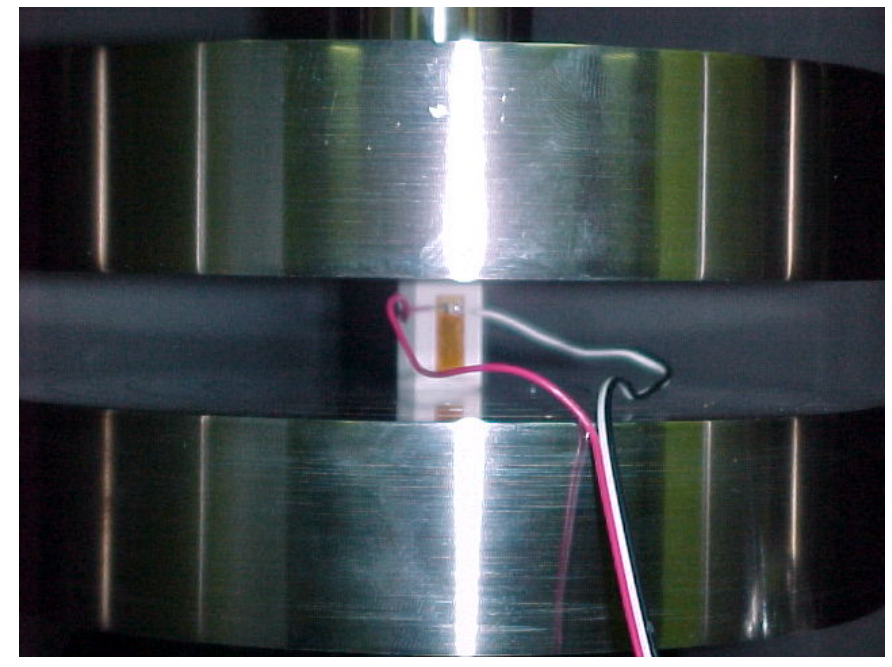

Figure 3.7 Compression Specimen Orientation

\subsubsection{Impact Test}

\subsubsection{Test Specimen}

The impact test specimens are in accordance with the standards set by ASTM D25-93a for an Izod type test. Figure 3.8 shows typical design parameters for an Izod impact test specimen. The actual dimensions of the specimen used in the impact testing are shown in Table 3.5.

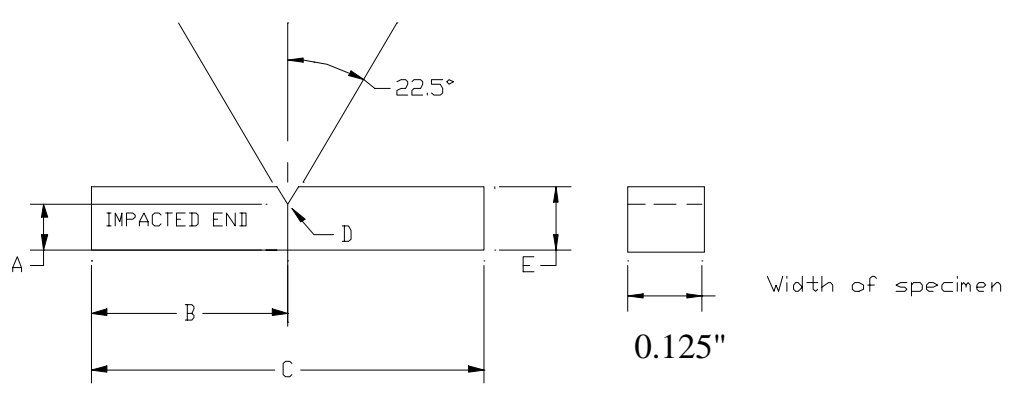

Fig. 3.8 Impact Test Specimen 
Table 3.5 Dimensions of Impact Test Specimen

\begin{tabular}{|c|c|c|}
\hline Dimension (Fig. 3.8) & ABS Specimens & PC Specimens \\
\hline A & $0.4085^{\prime \prime}$ & $0.4085^{\prime \prime}$ \\
\hline B & $1.25^{\prime \prime}$ & $1.25^{\prime \prime}$ \\
\hline C & $2.5^{\prime \prime}$ & $2.5^{\prime \prime}$ \\
\hline D & $0.25 \mathrm{R}$ & $0.25 \mathrm{R}$ \\
\hline E & $0.5^{\prime \prime}$ & $0.5^{\prime \prime}$ \\
\hline
\end{tabular}

\subsubsection{Specimen Preparation}

No specimen preparation was performed on the Izod impact specimens. Owens Corning carried out notching on the specimen as per ASTM specifications.

\subsubsection{Test Set-up and Procedure}

The impact testing was conducted as per ASTM D256-93a method A using a BLI Series Impact Testing Machine shown in Fig. 3.9. The test was conducted without any weight addition to the Izod pendulum. The final impact energy was obtained from the pointer reading and the type of break (i.e. H-hinge, C-complete, or P-Partial) was recorded. The results were calibrated using a standard correction chart supplied by Instron to account for pendulum friction and windage (BLI Series Manual, 1999).

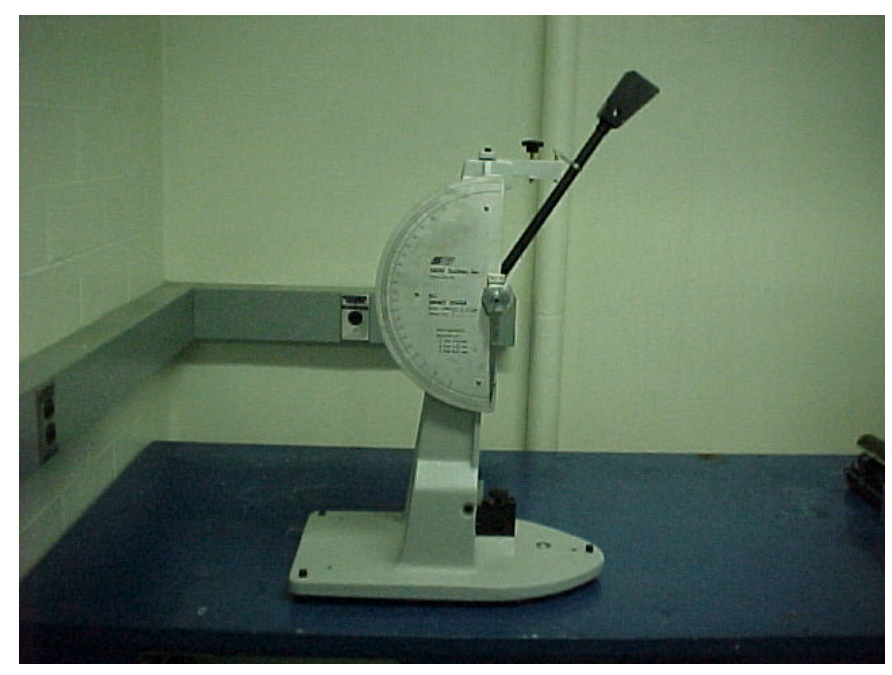

Figure 3.9 BLI Series Impact Testing Machine 


\subsubsection{Creep Test}

\subsubsection{Test Specimen}

The test specimens chosen for use in the creep test have the same dimensions as in tension. Additional modifications as explained under specimen preparation were carried out.

\subsubsection{Specimen Preparation}

Two 3/8" diameter holes were drilled at both ends with their centers at a distance of $1.125 "$ from the end and $0.375 "$ from the sides as shown in Fig. 3.10. On one end of the specimen, two $2.25 " \mathrm{x} 1$ "x $0.125 "$ aluminum tabs with a $0.375 "$ diameter hole in the center of the tabs were attached on each side. Surface preparation and strain gage application were similar as explained in bending tests. A threaded bolt measuring $0.375 "$ in diameter and 1.5" in length was passed through the aluminum tabs and holes and tightened on to the flange of a steel beam with threaded holes as shown in Fig. 3.11. Thus, the specimen was suspended from the beam. Free end of the specimen was attached with $5 " x 1 " x 0.125 "$ steel plates with a $0.375 "$ diameter hole for suspending a known dead weight. To further ensure that no slippage occurred between the specimen and the tabs, two C-clamps were applied at each end of the specimen, one on each side of the bolt, as shown in Fig. 3.11.

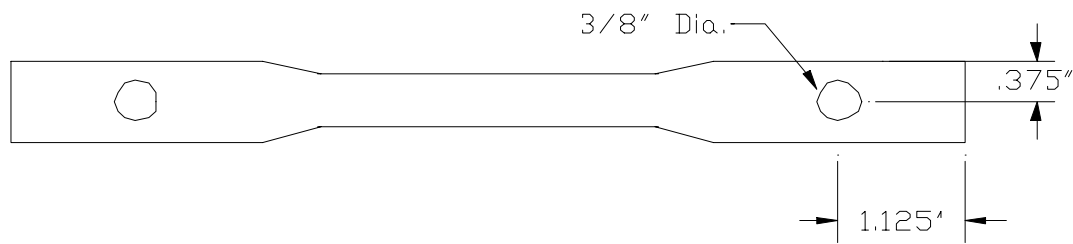

Fig. 3.10 Creep Specimen with Drilled Holes 


\subsubsection{Test Set-up and Procedure}

The load was applied by suspending large steel plates with known weights from the specimen by means of a $1 / 8$ " cables. In some cases, the same sustained load was used to simultaneously apply the sustained load on two different specimens connected in series. In Fig. 3.12, specimens at both ends of the steel beams are suspended in series.

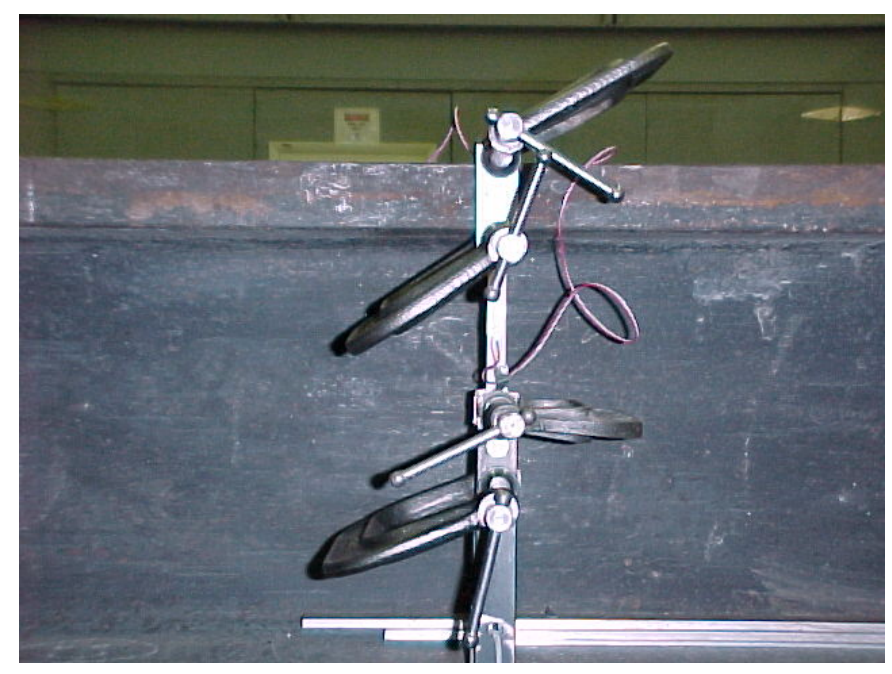

Figure 3.11 Creep Specimen Set-Up Procedure

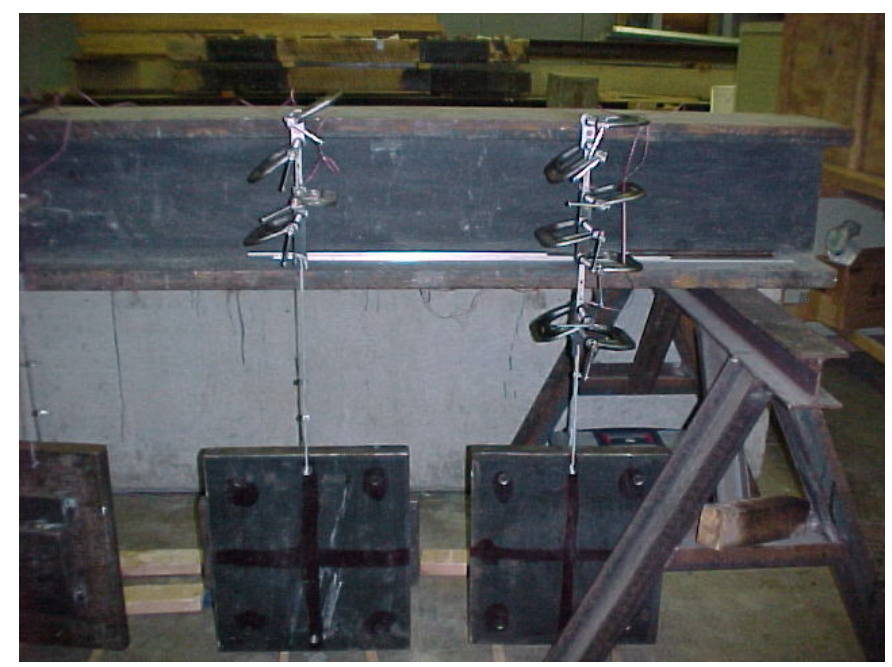

Figure 3.12 Test Set-Up for Creep Test 


\subsubsection{Hardness Test}

\subsubsection{Test Specimen}

The hardness specimens are in accordance with the standards set by ASTM D2240-91. The ABS samples are of 2" diameter with a thickness of 0.125". The PC samples are of 3" diameter with a thickness of 0.125". Each specimen was labeled according to the type of test conducted and the test number. For example, a specimen designated as HP1-2 represents, hardness test $(\mathrm{H})$, sample group (P1 - 100\% PC virgin sample without fibers), and the test number 2 .

\subsubsection{Specimen Preparation}

No specimen preparation was performed on the hardness test specimens.

\subsubsection{Test Set-up and Procedure}

The hardness testing was performed using a Duotronic Model 2000 hardness testing machine per ASTM D2240-91. Two tests were conducted on each specimen, one using a $626 \mathrm{~g}$ weight and the other with no weight. The hardness number was recorded from the Doutronic's visual display for each test. The test set-up and specimen orientation can be seen on Figure 3.13.

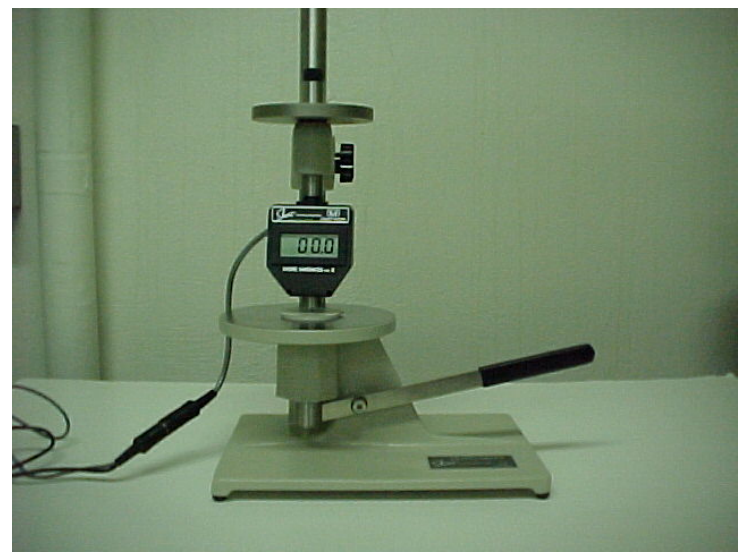

Figure 3.13 Test Set-Up for Hardness Test 


\section{CHAPTER 4}

\section{TEST RESULTS, ANALYSIS, AND DISCUSSIONS}

\subsection{Introduction}

Experimental evaluations of the strength and stiffness properties of PC and ABS plastics are very important for developing good design approaches for infrastructure and automotive applications. These resins alone often do not have the strength or stiffness to meet the requirements of certain automobile or construction applications. Hence, to obtain improved mechanical properties, the polymers are evaluated by adding fibers during the manufacturing process.

Experimental results and the analysis and discussion of those results based on coupon level testing are presented in this chapter. The stiffness values for ABS and PC is obtained from tension, compression, and bending tests from specimens with and without fibers. Other values presented in this chapter include maximum stress, impact strength, hardness values, and creep coefficients.

\subsection{Tension Test}

\subsubsection{Results of Tension Tests on ABS}

Strength and stiffness results from the tension tests are summarized in Table 4.1. Each result is an average of at least 5 specimens. Results for individual tests are shown in Appendix-A, including statistical analysis of the data. Virgin polymers and recycled polymers without fibers showed elongation in excess of $10 \%$. Extensometer used in this study had a limit of $10 \%$ on strain measurements and hence the strain readings were discontinued at about $8 \%$ strain. Comparison of tensile stress and stiffness is shown in 
Figs. 4.1 and 4.2. Typical stress-strain curves are shown in Figs. 4.3 and 4.4 for virgin ABS without and with fibers.

\section{Table 4.1 Tension Test Results on ABS}

\begin{tabular}{|c|c|c|c|c|}
\hline Specimen & Maximum Load & $\begin{array}{c}\text { Maximum } \\
\text { Stress }\end{array}$ & $\begin{array}{c}\text { Strain @ Max. } \\
\text { Load }\end{array}$ & $\begin{array}{c}\text { Tensile Stiffness } \\
\text { (E) }\end{array}$ \\
\hline & lbs. & psi & $\%$ & psi \\
\hline TA1 & 385.88 & 6174.14 & 2.87 & $0.321 \mathrm{E}+06$ \\
\hline TA2 & 643.71 & 10299.42 & 1.35 & $0.976 \mathrm{E}+06$ \\
\hline TA3 & 348.68 & 5578.85 & 2.85 & $0.333 \mathrm{E}+06$ \\
\hline TA4 & 550.03 & 8800.54 & 1.12 & $0.964 \mathrm{E}+06$ \\
\hline TA5 & 369.75 & 5915.94 & 2.76 & $0.359 \mathrm{E}+06$ \\
\hline TA6 & 556.96 & 8911.39 & 1.18 & $0.941 \mathrm{E}+06$ \\
\hline
\end{tabular}

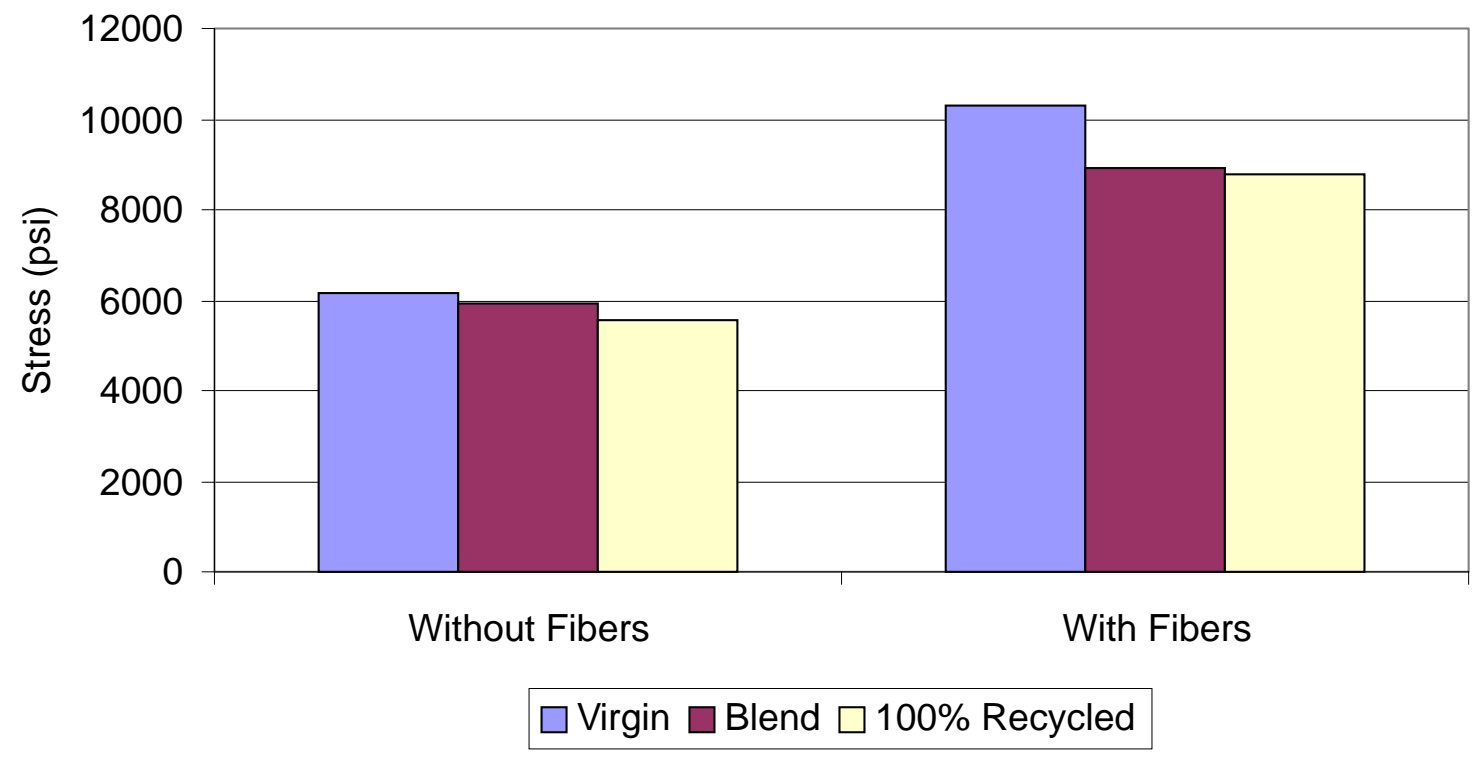

Fig. 4.1 Comparison of Maximum Tensile Stresses in ABS (12\% Fiber Volume Fraction) 


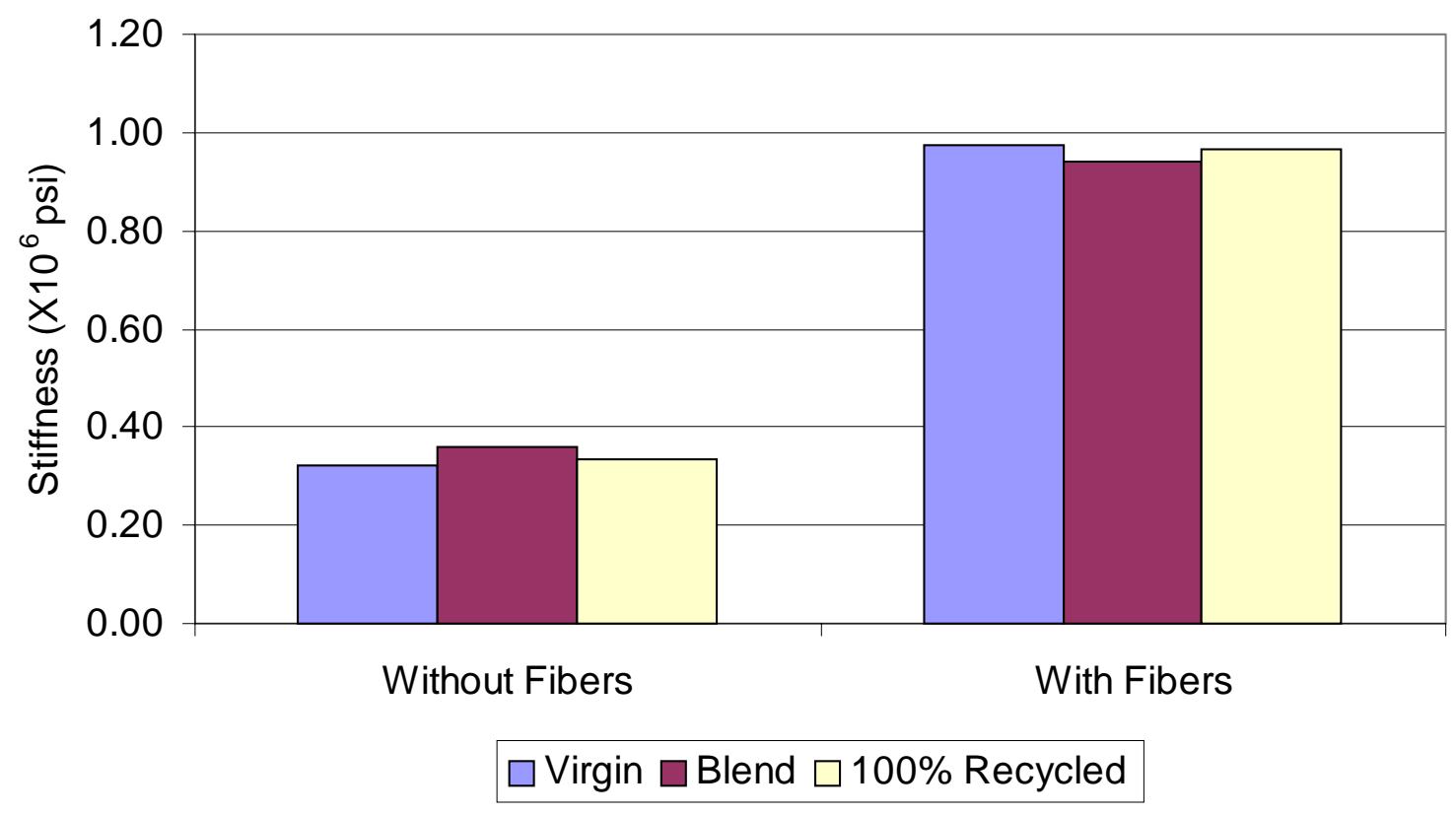

Fig. 4.2 Comparison of Maximum Tensile Stiffness in ABS (12\% Fiber Volume Fraction)

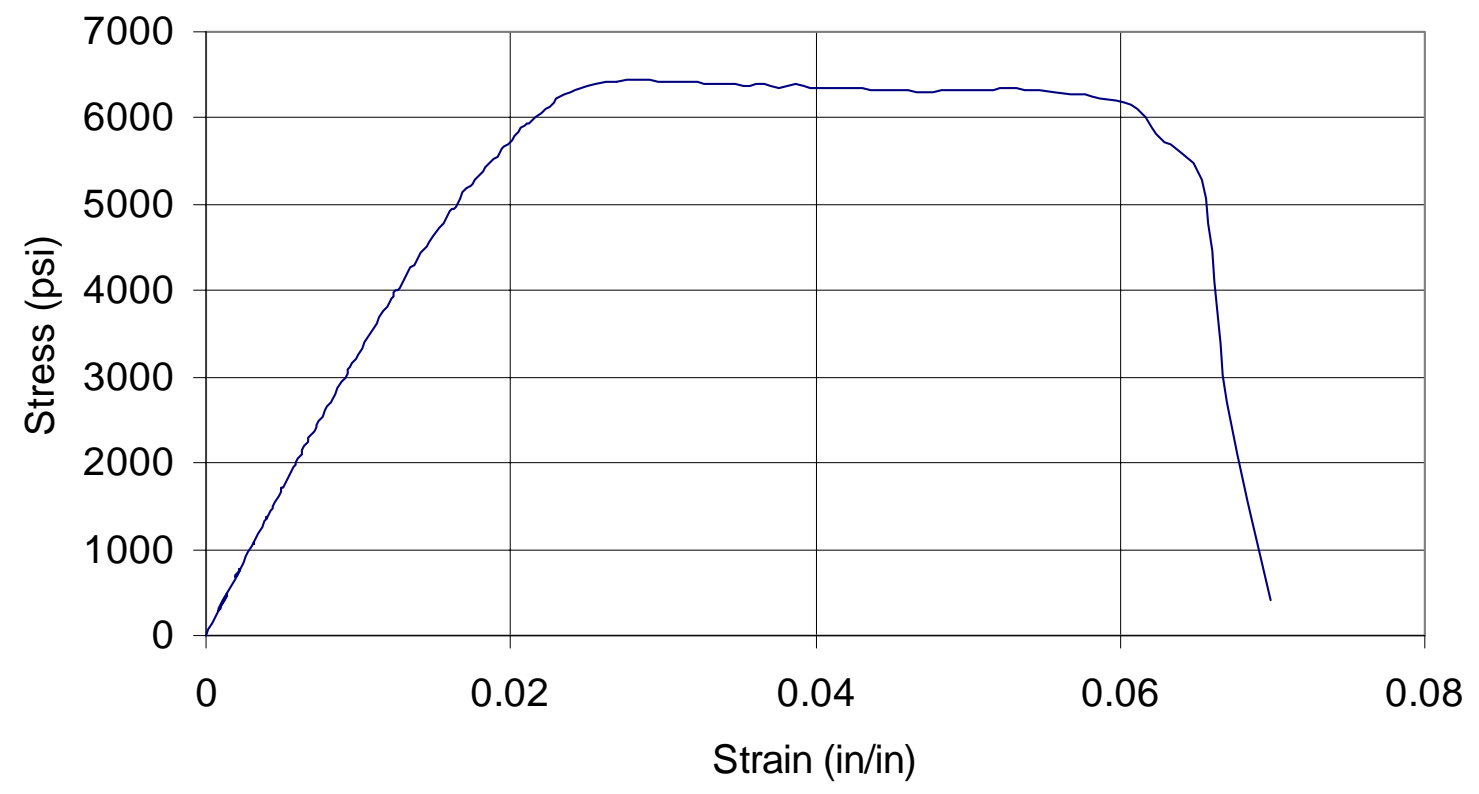

Fig. 4.3 Typical Stress-Strain Curve for Virgin ABS without Fibers in Tension 


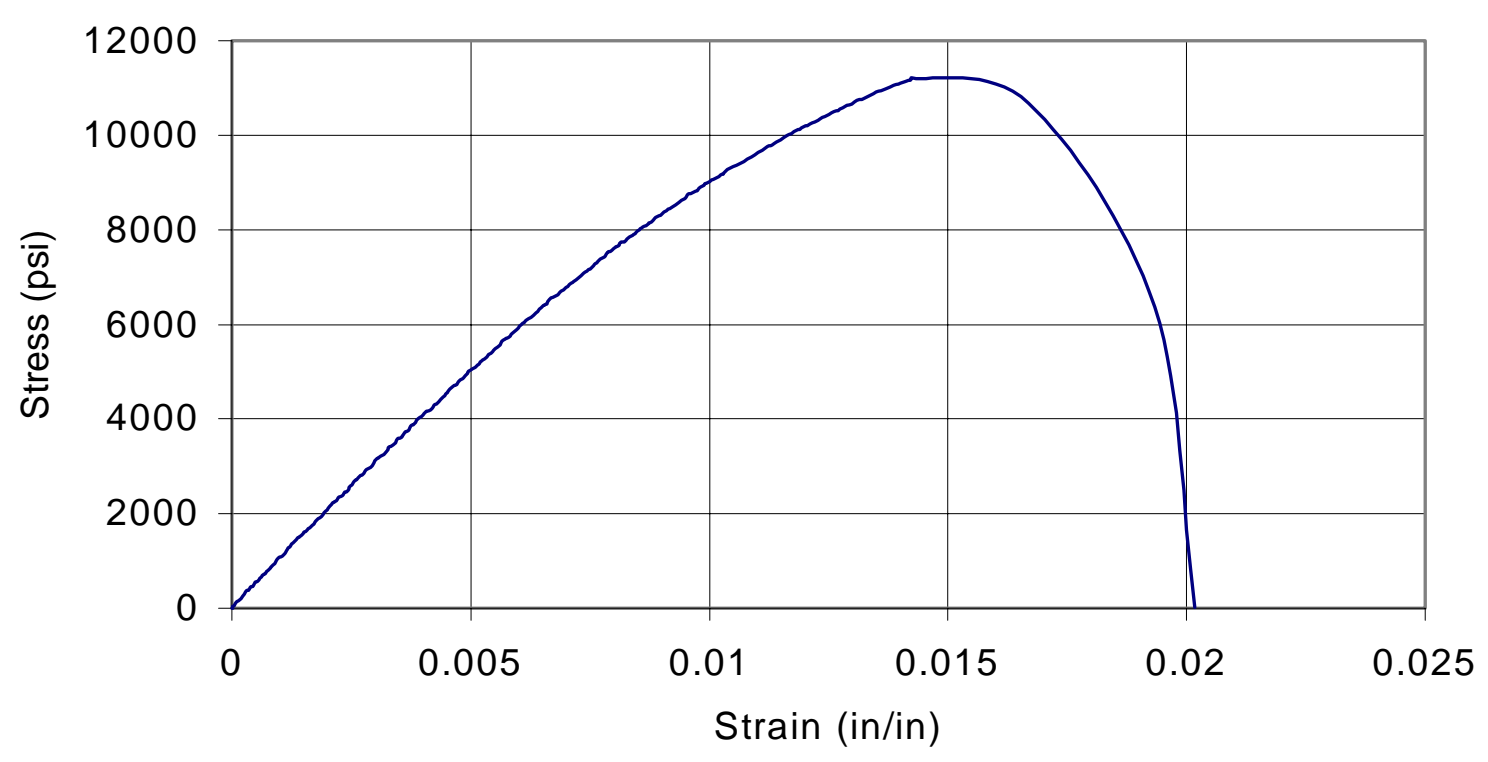

Fig. 4.4 Typical Stress-Strain Curve for Virgin ABS with 12\% Fiber Volume Fraction in Tension

\subsubsection{Analysis and Discussion of Tension Test Results on ABS}

Stiffness of the specimens was evaluated through regression analysis by providing best-fit curve to the linear portion of the stress-strain curve. Analysis of test results is shown in Table 4.2.

Table 4.2 Analysis and Comparison of Tension Test Results on ABS (\% Increase/Decrease)

\begin{tabular}{|c|l|l|r|r|r|}
\hline Effect of & \multicolumn{1}{|c|}{$\begin{array}{c}\text { Specimen } \\
\text { Type }\end{array}$} & $\begin{array}{c}\text { Compared } \\
\text { With }\end{array}$ & $\begin{array}{c}\text { Max. Tensile } \\
\text { Stress }\end{array}$ & $\begin{array}{c}\text { Tensile } \\
\text { Stiffness }\end{array}$ & $\begin{array}{c}\text { Strain @ } \\
\text { Max. Stress }\end{array}$ \\
\hline & & & $\mathbf{\%}$ & $\mathbf{\%}$ & $\mathbf{\%}$ \\
\hline \multirow{2}{*}{$\begin{array}{c}\text { Recycling } \\
\text { (Without Fibers) }\end{array}$} & TA3 (R) & \multirow{2}{*}{ TA1 (V) } & -9.6 & +3.7 & -0.7 \\
\cline { 2 - 4 } & TA5 (B) & & -4.2 & +11.8 & -3.8 \\
\hline \multirow{2}{*}{$\begin{array}{c}\text { Recycling } \\
\text { (With Fibers) }\end{array}$} & TA4 (R-F) & \multirow{2}{*}{ TA2 (V-F) } & -14.6 & -1.2 & -17.0 \\
\cline { 2 - 6 } & TA6 (B-F) & & -13.5 & -3.6 & -12.6 \\
\hline \multirow{2}{*}{ Fiber Addition } & TA2 (V-F) & TA1 (V) & +66.8 & +204.0 & -53.0 \\
\cline { 2 - 6 } & TA4 (R-F) & TA3 (R) & +57.5 & +189.5 & -60.7 \\
\cline { 2 - 6 } & TA6 (B-F) & TA5 (B) & +50.6 & +162.1 & -57.2 \\
\hline
\end{tabular}

Note: T-Tension; A-ABS; V-Virgin; R-100\% Recycled; B-Blend (80\% virgin and 20\% Recycled); F-Fiber; +ve sign-Increase; -ve sign- Reduction. Refer to Table 4.1 for absolute values. 
- Compared to virgin polymers, maximum tensile stress in the blend and $100 \%$ recycled polymers reduced by $4.2 \%$ and $9.6 \%$ respectively. However, blend and recycled polymer stiffness increased by 11.8 and 3.7\%, respectively.

- Compared to virgin polymers with fibers, maximum tensile stress reductions in the blend and $100 \%$ recycled polymers with fibers were found to be between 13.5 and $14.6 \%$, respectively. Similarly, blend and $100 \%$ recycled polymer stiffness reductions were found to be 1.2 and $3.6 \%$, respectively.

- Addition of $12 \%$ fiber volume fraction of randomly oriented and chopped glass fibers to virgin, blend and $100 \%$ recycled polymers resulted in a tensile stress increase of $66.8,50.6$, and $57.7 \%$ respectively. Similarly, stiffness increase was found to be 204.0, 162.1 and $189.5 \%$ respectively for the virgin, blend and $100 \%$ recycled polymers.

- Virgin polymers without fibers showed elongation in excess of $10 \%$. Extensometer available with the Instron machine had a maximum capacity of $10 \%$. Hence the, strain measurements were discontinued. Strain values of recycled and blend specimens were less than the strains of virgin polymers. Addition of fibers reduced the failure strain values in virgin, blend and $100 \%$ recycled polymers to $1.35,1.18$ and $1.12 \%$, respectively.

\subsubsection{Results of Tension Tests on PC}

Strength and stiffness results of tension tests are summarized in Table 4.3. Each result is an average of at least 5 specimens. Results for individual tests are shown in Appendix-A, including statistical analysis of the data. Virgin polymers and recycled 
polymers without fibers showed elongation in excess of $10 \%$. Extensometer used in this study had a limit of $10 \%$ on strain measurements; hence the strain readings were discontinued at about 9\% strain. Typical stress-strain curves are shown in Figs. 4.7 and 4.8 for virgin PC without and with fibers. It is noted that the PC polymer exhibits two stiffness values, E1 and E2, during testing. For the virgin, 100\% recycled, and blend PC polymer with fibers, the second stiffness value, E2, is $41-47 \%$ of E1 and begins at approximately $72-78 \%$ of the maximum stress $(\approx 12000$ psi $)$. For the virgin, $100 \%$ recycled, and blend $\mathrm{PC}$ polymer without fibers, the second stiffness value, E2, is $47-52 \%$ of E1 and begins at approximately $57 \%$ of the maximum stress ( $\approx 5000 \mathrm{psi})$. Comparison of tensile stress and stiffness is shown in Figs. 4.5 and 4.6.

Table 4.3 Tension Test Results on PC

\begin{tabular}{|c|c|c|c|c|c|c|c|}
\hline Specimen & $\begin{array}{c}\text { Maximum } \\
\text { Load }\end{array}$ & $\begin{array}{c}\text { Maximum } \\
\text { Stress }\end{array}$ & $\begin{array}{c}\text { Strain @ } \\
\text { Max. Load }\end{array}$ & $\begin{array}{c}\text { Tensile } \\
\text { Stiffness } \\
\text { (E1) }\end{array}$ & $\begin{array}{c}\text { Tensile } \\
\text { Stiffness } \\
\text { (E2) }\end{array}$ & E2/E1 & E1/є2 \\
\hline & lbs. & psi & $\%$ & psi & psi & $\%$ & $\%$ \\
\hline TP1 & 556.21 & 8664.76 & 7.27 & $0.300 \mathrm{E}+06$ & $0.147 \mathrm{E}+06$ & 49.0 & 61.5 \\
\hline TP2 & 1057.82 & 16479.06 & 3.14 & $1.029 \mathrm{E}+06$ & $0.431 \mathrm{E}+06$ & 41.8 & 51.5 \\
\hline TP3 & 549.87 & 8566.05 & 7.33 & $0.293 \mathrm{E}+06$ & $0.139 \mathrm{E}+06$ & 47.4 & 66.7 \\
\hline TP4 & 976.58 & 15213.48 & 2.68 & $0.993 \mathrm{E}+06$ & $0.417 \mathrm{E}+06$ & 41.9 & 48.7 \\
\hline TP5 & 573.01 & 8926.44 & 7.03 & $0.329 \mathrm{E}+06$ & $0.169 \mathrm{E}+06$ & 51.3 & 58.8 \\
\hline TP6 & 1062.74 & 16555.71 & 2.95 & $1.046 \mathrm{E}+06$ & $0.490 \mathrm{E}+06$ & 46.8 & 48.9 \\
\hline
\end{tabular}




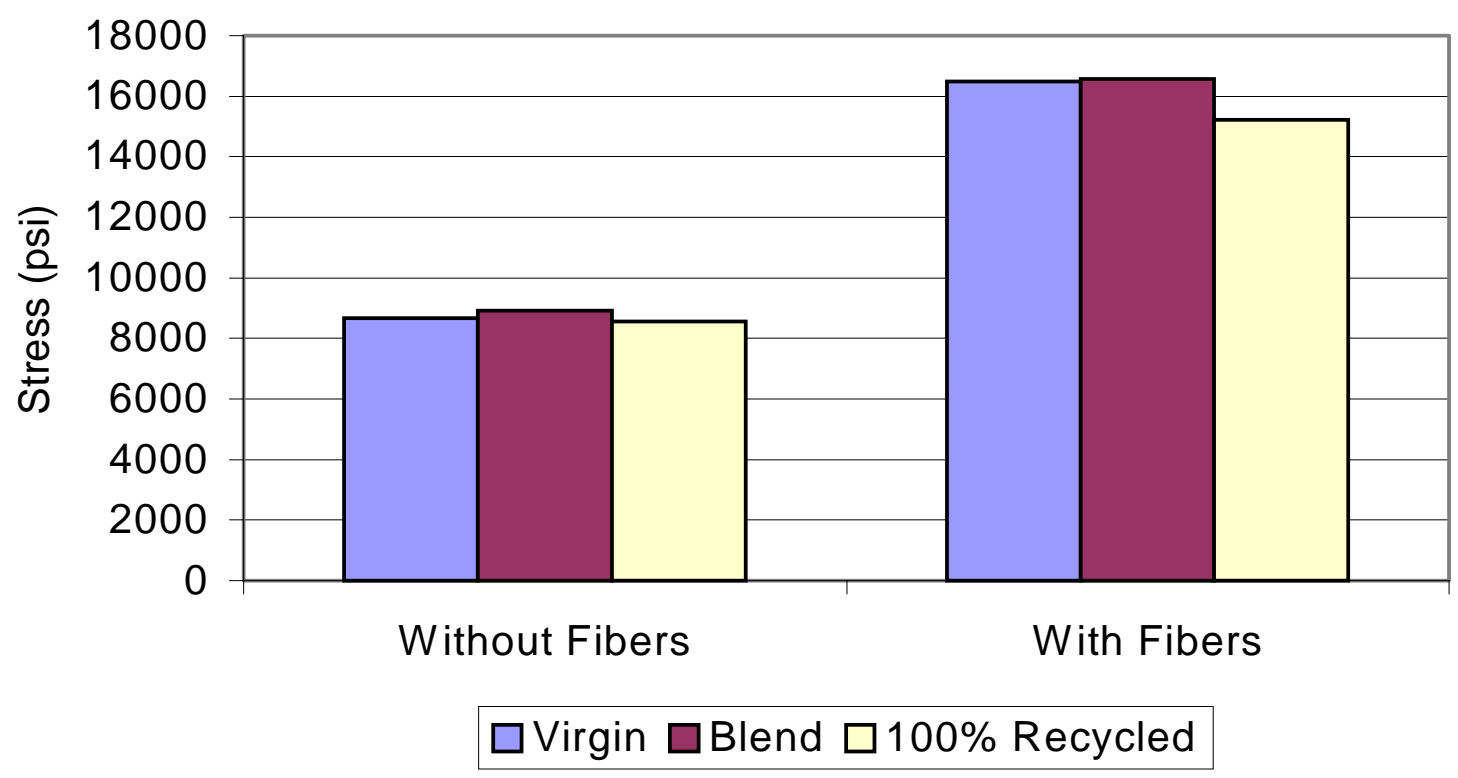

Fig. 4.5 Comparison of Maximum Tensile Stresses in PC (12\% Fiber Volume Fraction)

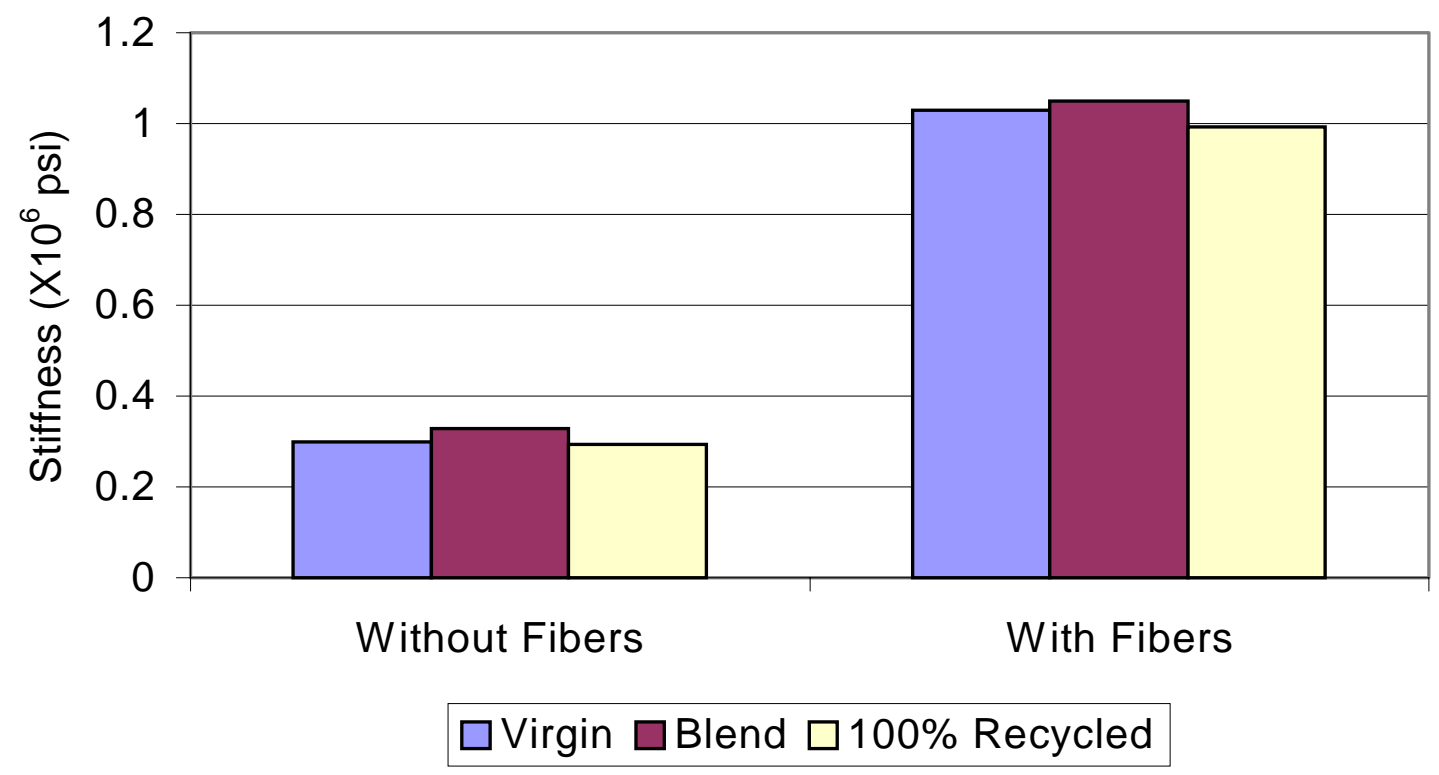

Fig. 4.6 Comparison of Maximum Tensile Stiffness in PC (12\% Fiber Volume Fraction) 


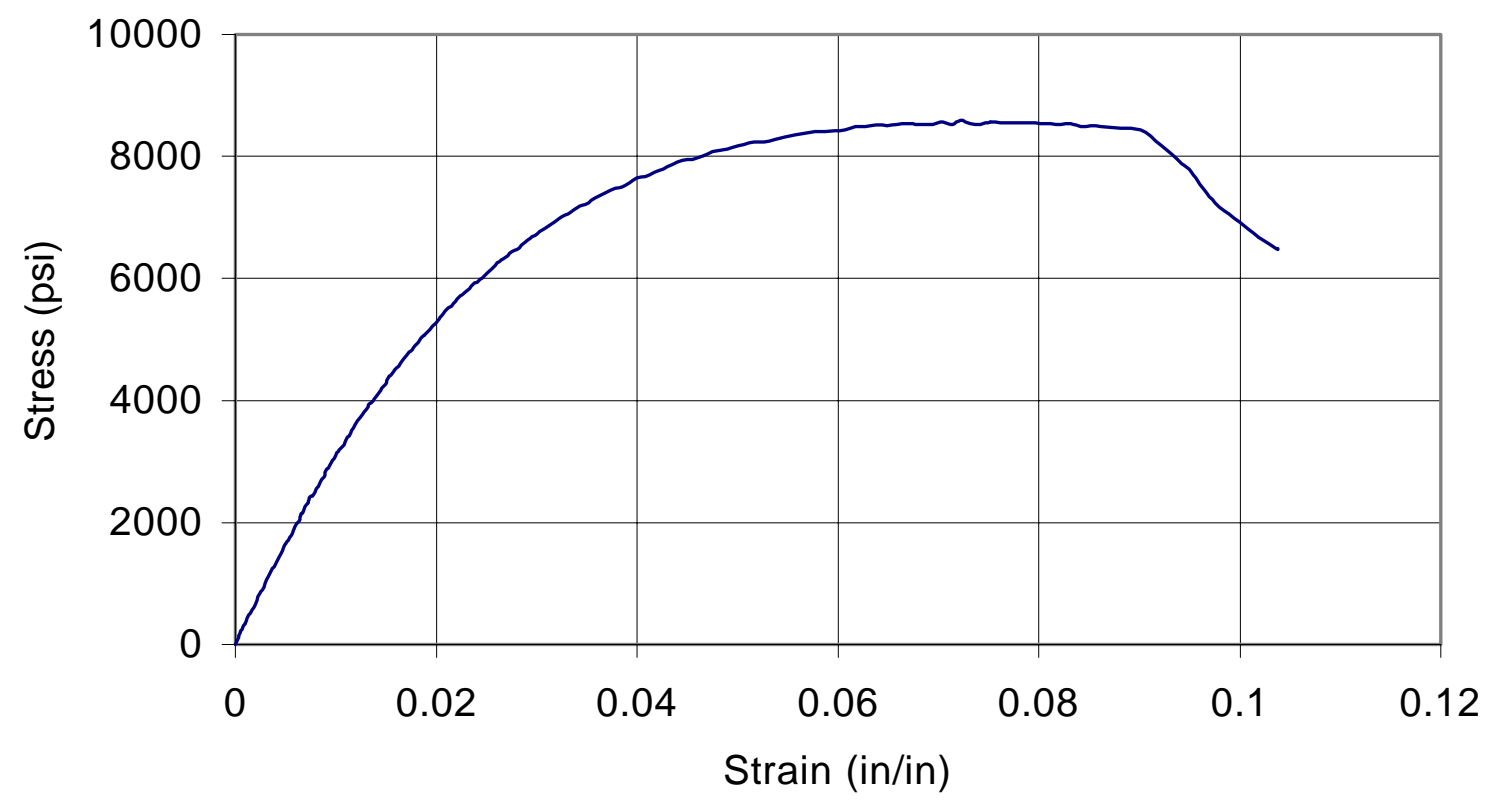

Fig. 4.7 Typical Stress-Strain Curve for Virgin PC without Fibers in Tension

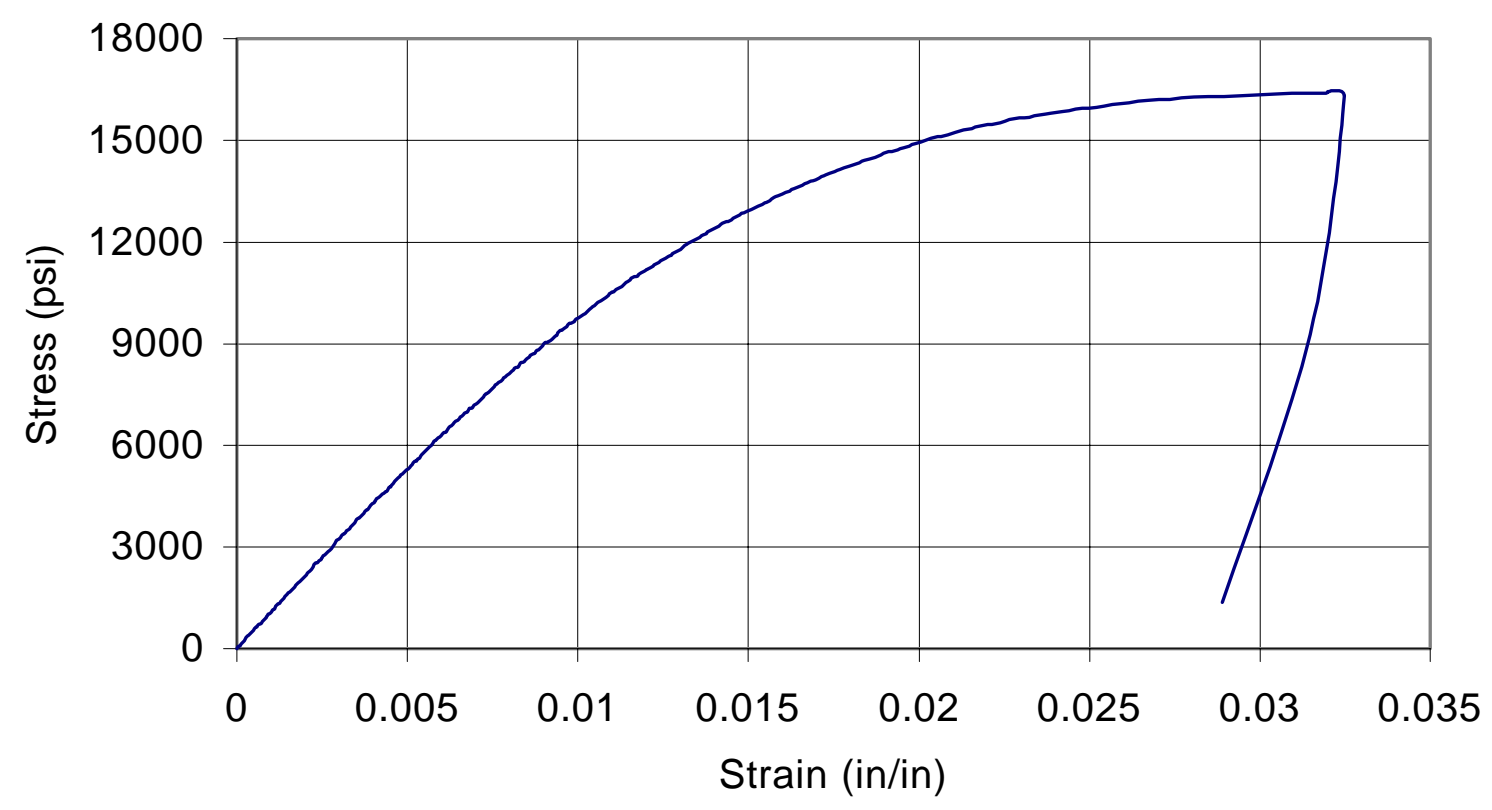

Fig. 4.8 Typical Stress-Strain Curve for Virgin PC with 12\% Fiber Volume Fraction in Tension 


\subsubsection{Analysis and Discussion of Tension Test Results on PC}

Stiffness of the specimens was evaluated through regression analysis by providing best-fit curve to the linear portion of the stress-strain curve. Analysis of the test results is shown in Table 4.4.

Table 4.4 Analysis and Comparison of Tension Test Results on PC (\% Increase/Decrease)

\begin{tabular}{|c|l|l|c|c|c|c|}
\hline Effect of & $\begin{array}{c}\text { Specimen } \\
\text { Type }\end{array}$ & $\begin{array}{c}\text { Compared } \\
\text { With }\end{array}$ & $\begin{array}{c}\text { Max. Ten. } \\
\text { Stress }\end{array}$ & \multicolumn{2}{|c|}{$\begin{array}{c}\text { Tensile Stiffness } \\
\text { \% }\end{array}$} & $\begin{array}{c}\text { Strain @ } \\
\text { Max. Stress }\end{array}$ \\
\hline & & & $\mathbf{\%}$ & $\mathbf{E 1}$ & $\mathbf{E 2}$ & \% \\
\hline \multirow{2}{*}{$\begin{array}{c}\text { Recycling } \\
\text { (Without Fibers) }\end{array}$} & TP3 (R) & \multirow{2}{*}{ TP1 (V) } & -1.1 & -2.3 & -5.4 & +0.8 \\
\cline { 2 - 7 } & TP5 (B) & & +3.0 & +9.7 & +15.0 & -3.3 \\
\hline $\begin{array}{c}\text { Recycling } \\
\text { (With Fibers) }\end{array}$ & TP4 (R-F) & \multirow{2}{*}{ TP2 (V-F) } & -7.7 & -3.4 & -3.2 & -14.6 \\
\cline { 4 - 7 } & TP6 (B-F) & & +0.5 & +1.7 & +13.7 & -6.1 \\
\hline \multirow{3}{*}{ Fiber Addition } & TP2 (V-F) & TP1 (V) & +90.2 & +243.0 & +193.0 & -56.8 \\
\cline { 2 - 7 } & TP4 (R-F) & TP3 (R) & +77.6 & +238.7 & +200.0 & -63.4 \\
\cline { 2 - 7 } & TP6 (B-F) & TP5 (B) & +85.5 & +217.9 & +189.9 & -58.0 \\
\hline
\end{tabular}

Note: T-Tension; P-PC; V-Virgin; R-100\% Recycled; B-Blend (80\% virgin and 20\% Recycled); F-Fiber; E1-First Stiffness; E2-Second Stiffness; +ve sign -Increase; -ve signReduction. Refer to Table 4.3 for absolute values.

- Compared to virgin polymers, maximum tensile stress in the blend increased by $3.0 \%$ whereas the $100 \%$ recycled polymers was nearly equal. Similarly, blend and $100 \%$ recycled polymer stiffness increased and decreased by 9.7 and $2.3 \%$, respectively.

- Compared to virgin polymers with fibers, maximum tensile stress reductions in the $100 \%$ recycled polymers with fibers were found to be $7.7 \%$ and increased by $0.5 \%$ in the blend. Similarly, blend and 100\% recycled polymer increased and decreased by 1.7 and $3.4 \%$, respectively. 
- Addition of $12 \%$ fiber volume fraction of randomly oriented and chopped glass fibers to virgin, blend and 100\% recycled polymers resulted in a tensile stress increase of 90.2, 85.5, and 77.6\% respectively. Similarly, stiffness increase for E1 was found to be $243.0,217.9$ and $238.7 \%$ respectively for the virgin, blend and $100 \%$ recycled polymers and 193.0, 189.9, and 200.0\% for E2.

- Virgin polymers without fibers showed elongation in excess of $10 \%$. Extensometer available with the Instron machine had a maximum capacity of $10 \%$ and hence the readings were discontinued. Strain values of recycled and blend specimens were less than the virgin polymers. It is noted that the PC polymer with fibers exhibited higher ductility than the ABS polymer with fibers. Addition of fibers in the PC polymer yielded maximum strain at failure values in virgin, blend and 100\% recycled polymers of $3.23,3.26$ and $2.96 \%$, respectively. For the ABS polymer with fibers, the maximum strain values at failure in virgin, blend and $100 \%$ recycled polymers was $1.51,1.18$ and $1.12 \%$, respectively.

\subsection{Bending Test}

\subsubsection{Results of Bending Tests on ABS}

Strength and stiffness results of the bending tests are summarized in Table 4.5. Each result is an average of at least 5 specimens. Results for individual tests are shown in Appendix-B, including statistical analysis of the data. Virgin polymers and recycled

polymers without fibers showed higher deflections in excess of $1 / 3^{\text {rd }}$ the test span of 3.75". Comparison of bending stress and stiffness is shown in Figs. 4.9 and 4.10. Typical load-deflection diagrams of polymer blend specimens without and with fibers are shown in Figs. 4.11 and 4.12. 
Table 4.5 Results of Bending Tests on ABS

\begin{tabular}{|c|c|c|c|c|}
\hline Specimen & $\begin{array}{c}\text { Maximum } \\
\text { Load }\end{array}$ & $\begin{array}{c}\text { Maximum } \\
\text { Stress }\end{array}$ & $\begin{array}{c}\text { Deflection @ } \\
\text { Max. Stress }\end{array}$ & $\begin{array}{c}\text { Bending Stiffness } \\
\text { (E) }\end{array}$ \\
\hline & lbs. & psi & in. & psi \\
\hline BA1 & 12.61 & 9080.23 & 0.67 & $0.40 \mathrm{E}+06$ \\
\hline BA2 & 24.68 & 17771.04 & 0.50 & $1.02 \mathrm{E}+06$ \\
\hline BA3 & 12.76 & 9187.20 & 0.69 & $0.40 \mathrm{E}+06$ \\
\hline BA4 & 23.25 & 16740.00 & 0.48 & $1.08 \mathrm{E}+06$ \\
\hline BA5 & 13.28 & 9558.72 & 0.70 & $0.40 \mathrm{E}+06$ \\
\hline BA6 & 22.93 & 16509.60 & 0.47 & $1.11 \mathrm{E}+06$ \\
\hline
\end{tabular}

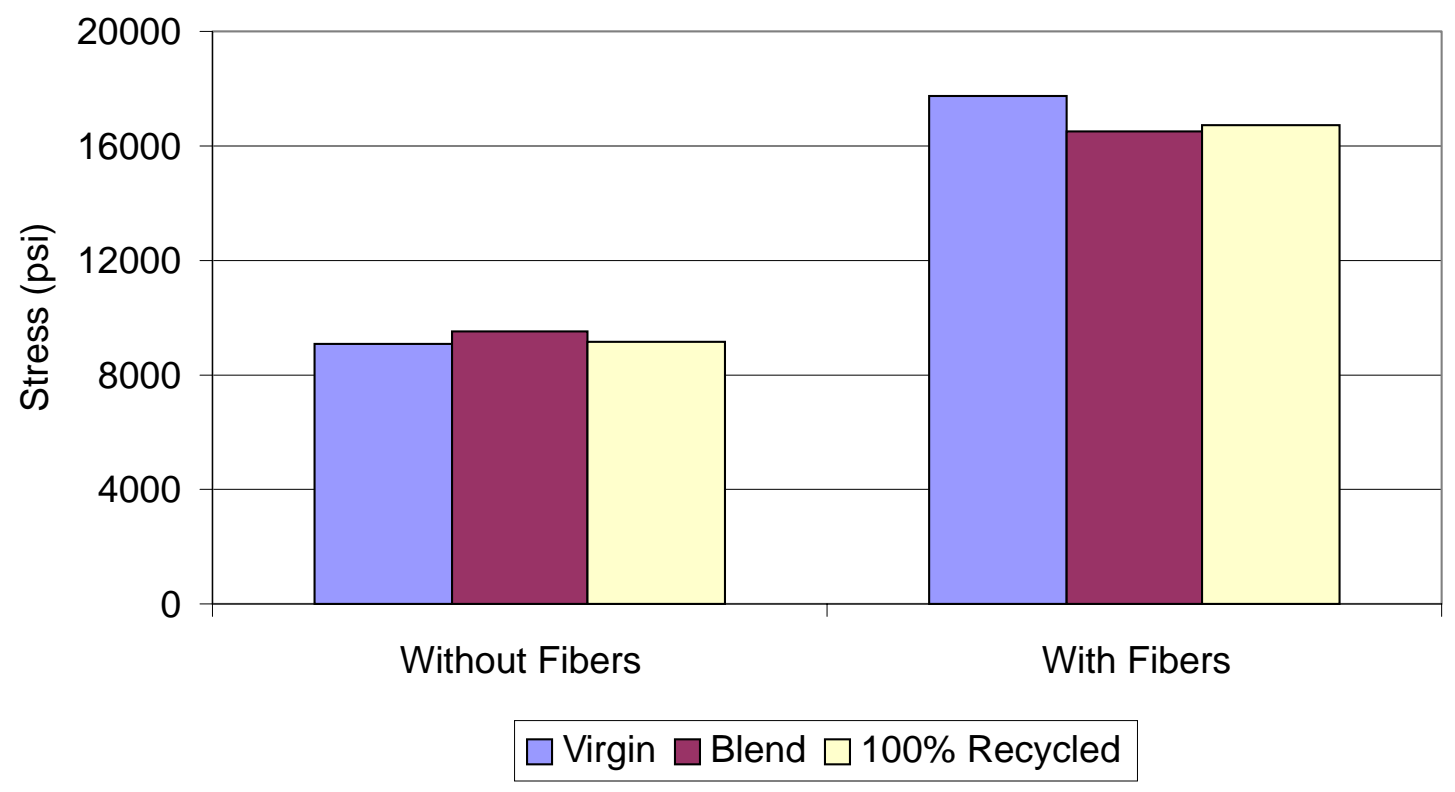

Fig. 4.9 Comparison of Maximum Bending Stresses in ABS (12\% Fiber Volume Fraction) 


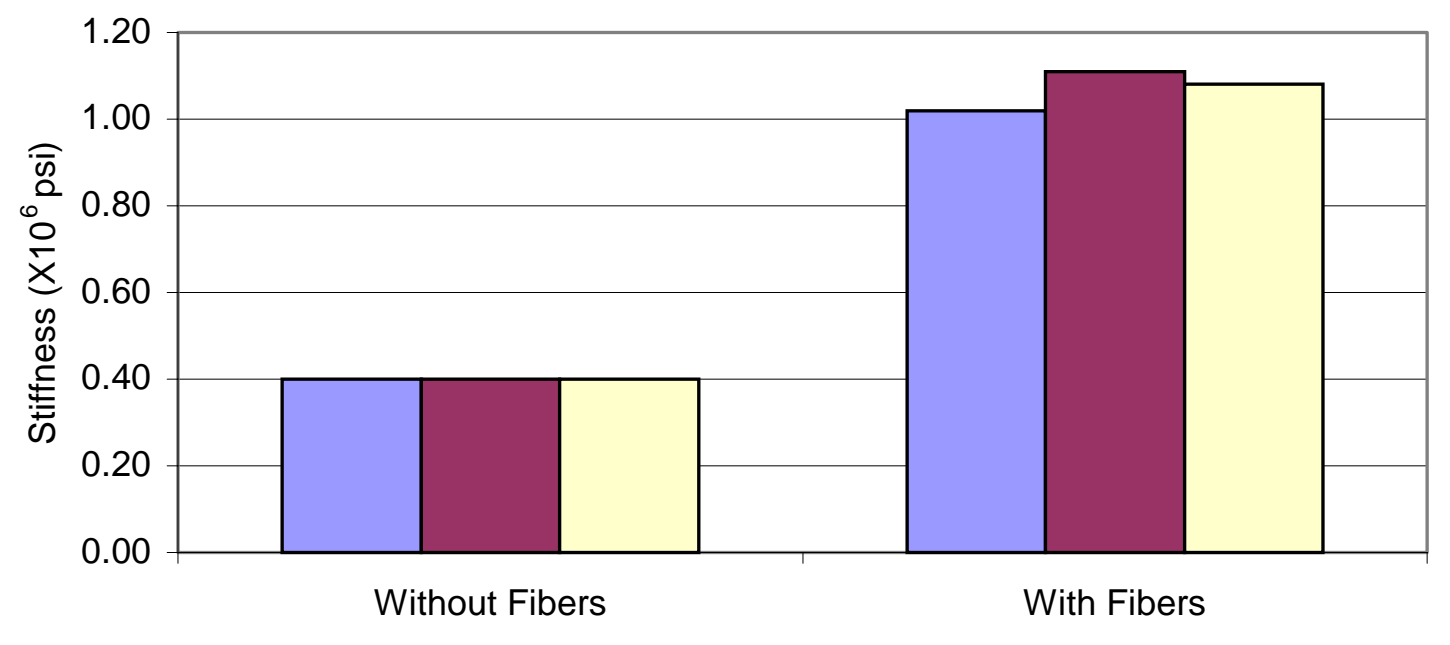

$\square$ Virgin $\square$ Blend $\square 100 \%$ Recycled

Fig. 4.10 Comparison of Maximum Bending Stiffness in ABS (12\% Fiber Volume Fraction)

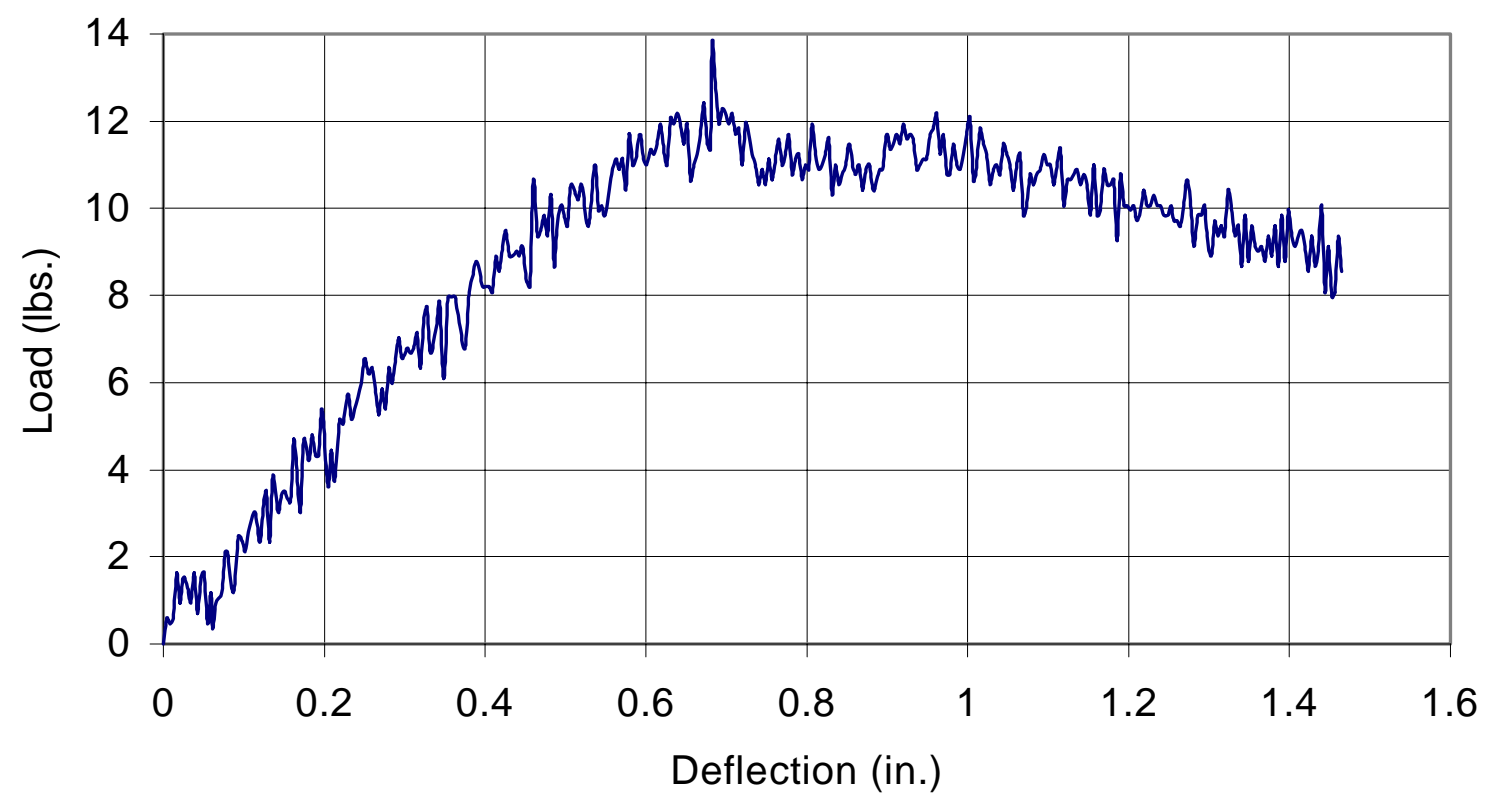

Fig. 4.11 Load-Deflection in Bending for ABS Polymer Blend Specimen without Fibers 


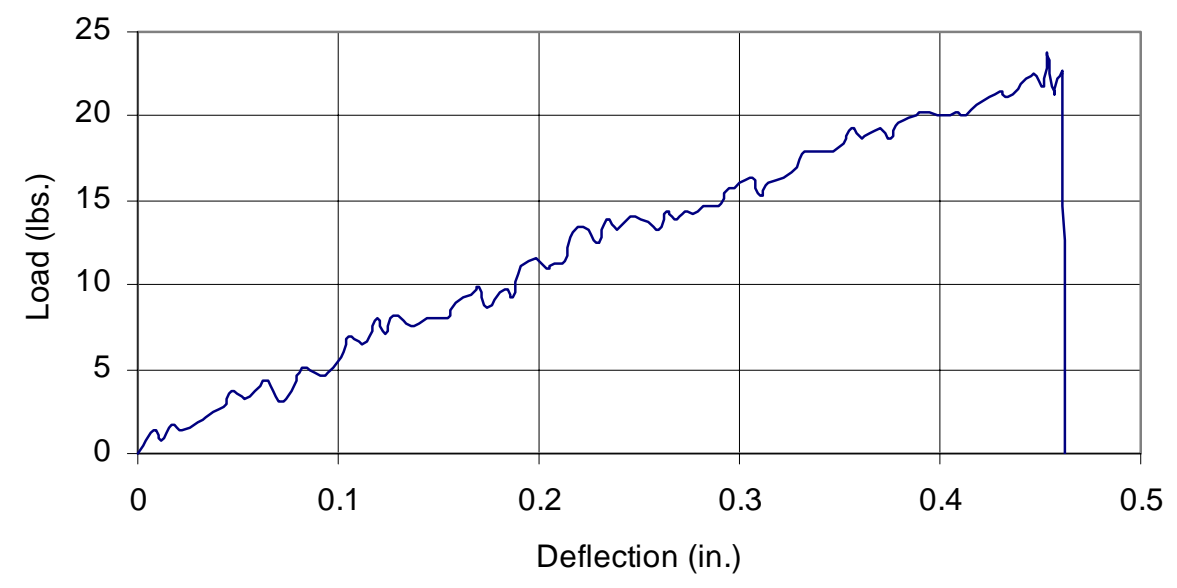

Fig. 4.12 Load-Deflection in Bending for ABS Polymer Blend Specimen with $12 \%$ Fiber Volume Fraction

\subsubsection{Analysis and Discussion of Bending Test Results on ABS}

Evaluation of stiffness was carried out using the slope of the load-deflection diagram in Euler's bending equation and the stiffness values were found to be lower than those recorded by strain gages. In this report bending stiffness values obtained through strain-gages are reported. Analysis of the test results is shown in Table 4.6.

Table 4.6 Analysis and Comparison of Bending Test Results on ABS

(\% Increase/Decrease)

\begin{tabular}{|c|l|l|r|r|r|}
\hline Effect of & \multicolumn{1}{|c|}{$\begin{array}{c}\text { Specimen } \\
\text { Type }\end{array}$} & $\begin{array}{c}\text { Compared } \\
\text { With }\end{array}$ & $\begin{array}{c}\text { Max. Tensile } \\
\text { Stress }\end{array}$ & $\begin{array}{c}\text { Tensile } \\
\text { Stiffness }\end{array}$ & $\begin{array}{c}\text { Strain @ } \\
\text { Max. Stress }\end{array}$ \\
\hline & & & $\mathbf{\%}$ & $\mathbf{\%}$ & \% \\
\hline \multirow{2}{*}{$\begin{array}{c}\text { Recycling } \\
\text { (Without Fibers) }\end{array}$} & BA3 (R) & \multirow{2}{*}{ BA1 (V) } & +1.2 & 0.0 & +3.0 \\
\cline { 2 - 4 } & BA5 (B) & & +5.3 & 0.0 & +4.5 \\
\hline $\begin{array}{c}\text { Recycling } \\
\text { (With Fibers) }\end{array}$ & BA4 (R-F) & \multirow{2}{*}{ BA2 (V-F) } & -5.8 & +5.9 & -4.0 \\
\cline { 2 - 5 } & BA6 (B-F) & & -7.1 & +8.8 & -6.0 \\
\hline \multirow{2}{*}{ Fiber Addition } & BA2 (V-F) & BA1 (V) & +95.7 & +155.0 & -25.4 \\
\cline { 2 - 6 } & BA4 (R-F) & BA3 (R) & +75.1 & +170.0 & -31.4 \\
\cline { 2 - 6 } & BA6 (B-F) & BA5 (B) & +72.7 & +177.5 & -32.9 \\
\hline
\end{tabular}

Note: B-Bending; A-ABS; V-Virgin; R-100\% Recycled; B (within brackets)-Blend (80\% virgin and 20\% Recycled); F-Fiber; +ve sign -Increase; -ve sign- Reduction. Refer to Table 4.5 for absolute values. 
- Compared to virgin polymers, maximum bending stress in the blend and $100 \%$ recycled polymers increased by $5.3 \%$ and $1.2 \%$ respectively. However, blend and $100 \%$ recycled polymer stiffnesses were identical to the virgin polymer.

- Compared to virgin polymers with fibers, maximum bending stress reductions in the blend and $100 \%$ recycled polymers with fibers were found to be 7.1 and $5.8 \%$, respectively. However, blend and $100 \%$ recycled polymer stiffness increases were found to be 8.8 and $5.9 \%$, respectively.

- Addition of $12 \%$ fiber volume fraction of randomly oriented and chopped glass fibers to virgin, blend and $100 \%$ recycled polymers resulted in a bending stress increase of 95.7, 72.7, and $75.1 \%$ respectively. Similarly, stiffness increase was found to be 155.0, 177.5 and $170.0 \%$ respectively for the virgin, blend and $100 \%$ recycled polymers.

\subsubsection{Results of Bending Tests on PC}

Strength and stiffness results of the bending tests are summarized in Table 4.7. Each result is an average of at least 5 specimens. Results for individual tests are shown in Appendix-B, including statistical analysis of the data. Virgin polymers and recycled

polymers without fibers showed higher deflections in excess of $1 / 3^{\text {rd }}$ the test span of 3.75". Comparison of bending stress and stiffness is shown in Figs. 4.13 and 4.14. Typical load-deflection diagrams of polymer blend specimens without and with fibers are shown in Figs. 4.15 and 4.16. 
Table 4.7 Results of Bending Tests on PC

\begin{tabular}{|c|c|c|c|c|}
\hline Specimen & $\begin{array}{c}\text { Maximum } \\
\text { Load }\end{array}$ & $\begin{array}{c}\text { Maximum } \\
\text { Stress }\end{array}$ & $\begin{array}{c}\text { Deflection @ } \\
\text { Max. Stress }\end{array}$ & $\begin{array}{c}\text { Bending Stiffness } \\
\text { (E) }\end{array}$ \\
\hline & lbs. & psi & in. & psi \\
\hline BP1 & 14.23 & 10242.72 & 0.87 & $0.332 \mathrm{E}+06$ \\
\hline BP2 & 34.12 & 24566.40 & 0.78 & $0.967 \mathrm{E}+06$ \\
\hline BP3 & 14.39 & 10363.68 & 0.81 & $0.291 \mathrm{E}+06$ \\
\hline BP4 & 32.22 & 23198.40 & 0.66 & $0.916 \mathrm{E}+06$ \\
\hline BP5 & 15.51 & 11168.64 & 0.90 & $0.327 \mathrm{E}+06$ \\
\hline BP6 & 34.56 & 24886.08 & 0.69 & $0.993 \mathrm{E}+06$ \\
\hline
\end{tabular}

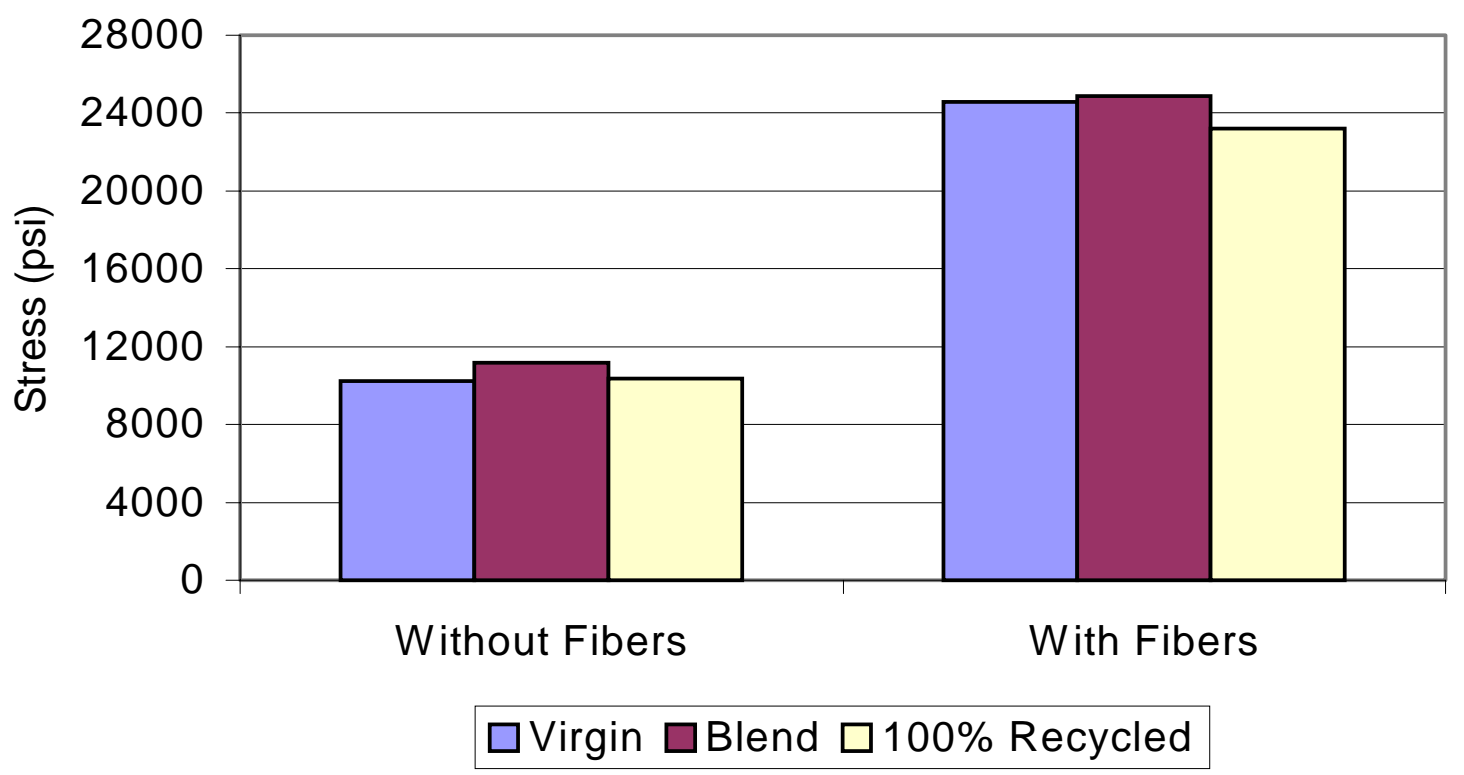

Fig. 4.13 Comparison of Maximum Bending Stresses in PC (12\% Fiber Volume Fraction) 


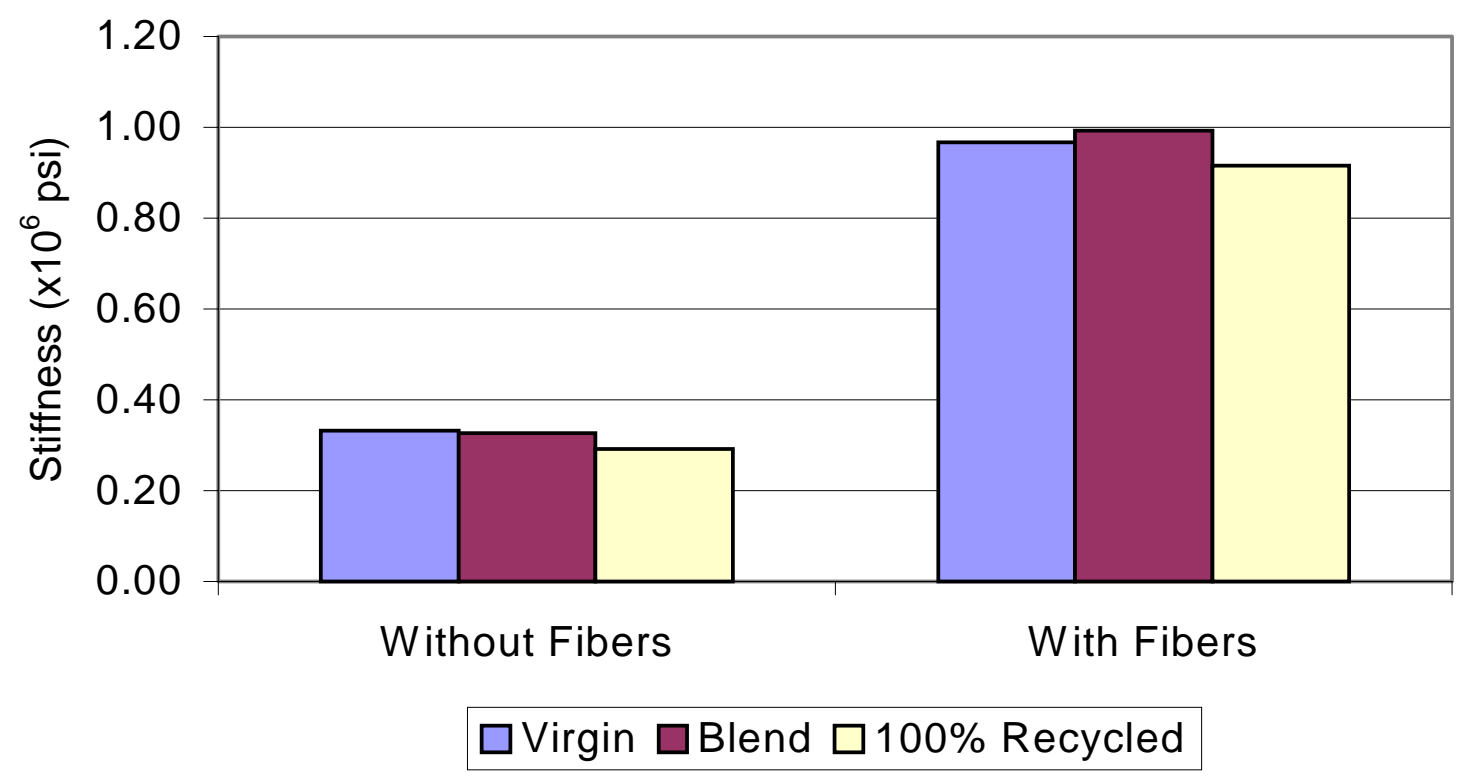

Fig. 4.14 Comparison of Maximum Bending Stiffness in PC (12\% Fiber Volume Fraction)

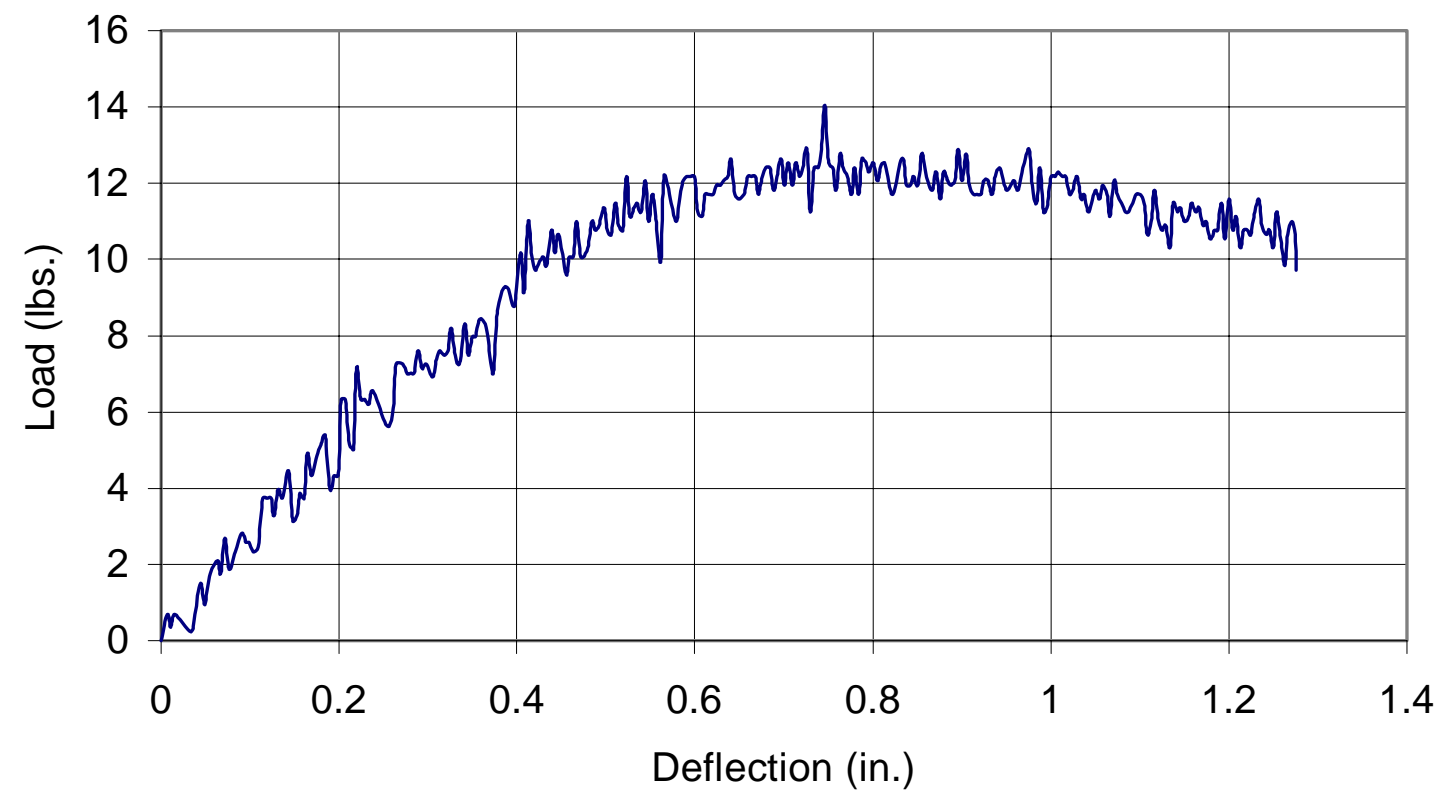

Fig. 4.15 Load-Deflection in Bending for PC Polymer Blend Specimen without Fibers 


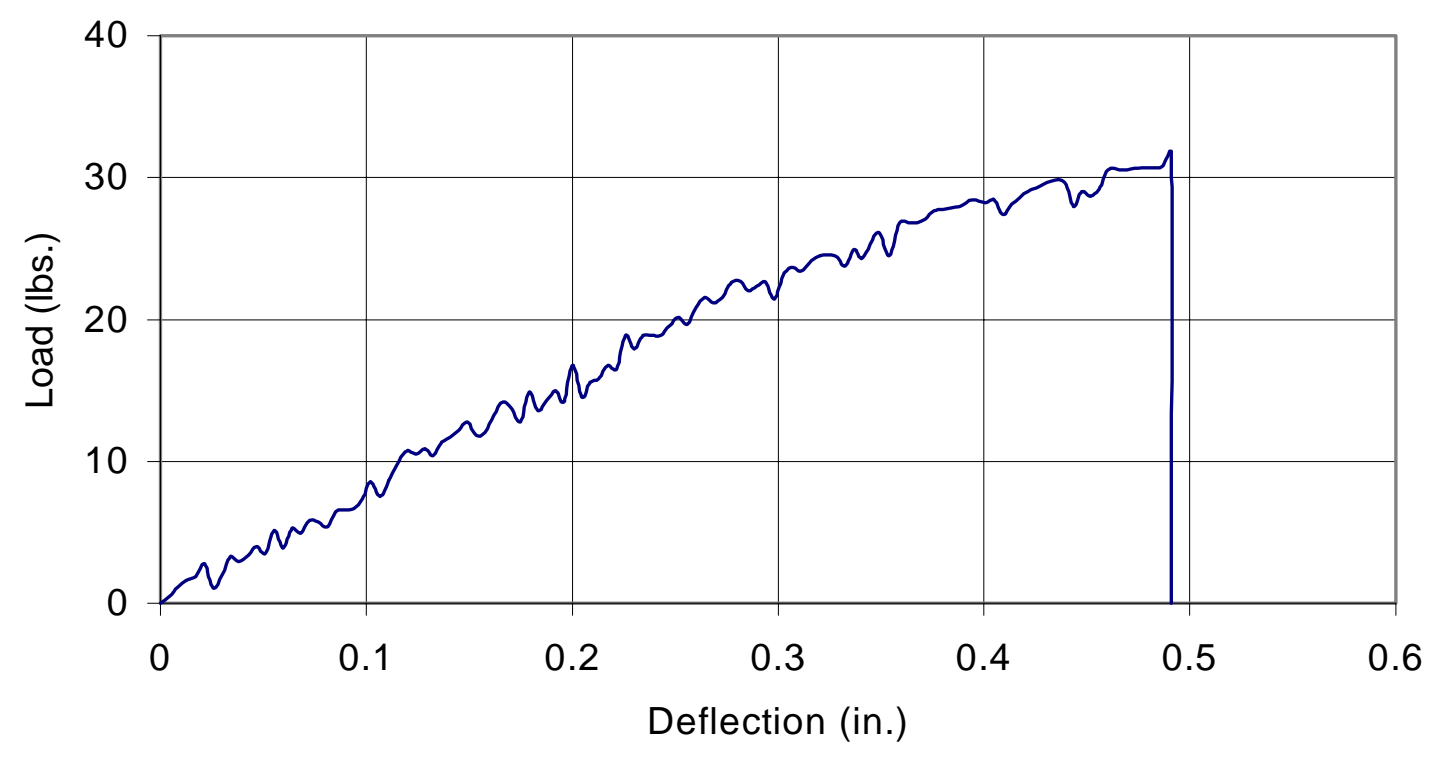

Fig. 4.16 Load-Deflection in Bending for PC Polymer Blend Specimen with $12 \%$ Fiber Volume Fraction

\subsubsection{Analysis and Discussion of Bending Test Results on PC}

Evaluation of stiffness was carried out using the slope of the load-deflection diagram in Euler's bending equation. Analysis of the test results is shown in Table 4.8.

Table 4.8 Analysis and Comparison of Bending Test Results on PC (\% Increase/Decrease)

\begin{tabular}{|c|c|c|c|c|c|}
\hline Effect of & $\begin{array}{c}\text { Specimen } \\
\text { Type }\end{array}$ & $\begin{array}{c}\text { Compared } \\
\text { With }\end{array}$ & $\begin{array}{l}\text { Max. Tensile } \\
\text { Stress }\end{array}$ & $\begin{array}{c}\text { Tensile } \\
\text { Stiffness }\end{array}$ & $\begin{array}{c}\text { Strain @ } \\
\text { Max. Stress }\end{array}$ \\
\hline & & & $\%$ & $\%$ & $\%$ \\
\hline \multirow{2}{*}{$\begin{array}{c}\text { Recycling } \\
\text { (Without Fibers) }\end{array}$} & BP3 (R) & \multirow{2}{*}{ BP1 (V) } & +1.1 & -12.3 & -6.9 \\
\hline & BP5 (B) & & +9.0 & -1.5 & +3.4 \\
\hline \multirow{2}{*}{$\begin{array}{c}\text { Recycling } \\
\text { (With Fibers) }\end{array}$} & BP4 (R-F) & \multirow{2}{*}{ BP2 (V-F) } & -5.8 & -5.3 & -15.4 \\
\hline & BP6 (B-F) & & +1.3 & +2.7 & -11.5 \\
\hline \multirow{3}{*}{ Fiber Addition } & BP2 (V-F) & $\mathrm{BP} 1(\mathrm{~V})$ & +139.8 & +191.3 & -10.3 \\
\hline & BP4 (R-F) & BP3 (R) & +123.9 & +214.8 & -18.5 \\
\hline & BP6 (B-F) & BP5 (B) & +122.8 & +203.7 & -23.3 \\
\hline
\end{tabular}

Note: B-Bending; P-PC; V-Virgin; R-100\% Recycled; B (within brackets)-Blend (80\% virgin and 20\% Recycled); F-Fiber; +ve sign -Increase; -ve sign- Reduction. Refer to Table 4.7 for absolute values. 
- Compared to virgin polymers, maximum bending stress in the blend and $100 \%$ recycled polymers increased by $9.0 \%$ and $1.1 \%$ respectively. However, blend and $100 \%$ recycled polymer stiffness decreased by 1.5 and $12.3 \%$ respectively.

- Compared to virgin polymers with fibers, maximum bending stress reduction in the $100 \%$ recycled polymers with fibers was found to be $5.8 \%$, whereas the blend bending stress increased by $1.3 \%$. Similarly, blend and $100 \%$ recycled polymer increased and decreased by 2.7 and 5.3\%, respectively.

- Addition of $12 \%$ fiber volume fraction of randomly oriented and chopped glass fibers to virgin, blend and $100 \%$ recycled polymers resulted in a bending stress increase of $139.8,122.8$, and $123.9 \%$ respectively. Similarly, stiffness increase was found to be 191.3, 203.7 and $214.8 \%$ respectively for the virgin, blend and $100 \%$ recycled polymers.

- Compared to the ABS polymer without fibers, the virgin, blend and $100 \%$ recycled PC polymer without fibers exhibited 11.3, 14.4, and 11.4\% higher maximum stress readings with $23.0,14.8$, and $22.2 \%$ more deflection at maximum stress, respectively.

- Compared to the ABS polymer with fibers, the virgin, blend and $100 \%$ recycled PC polymer with fibers exhibited $27.7,33.7$, and $27.8 \%$ higher maximum stress readings with $44.4,31.9$, and $27.3 \%$ more deflection at maximum stress, respectively.

\subsection{Compression Test}

\subsubsection{Results of Compression Tests on ABS}

Strength and stiffness results of the compression tests are summarized in Table 4.9. Each result is an average of at least 5 specimens with a height of 0.5 " and a cross- 
section of 0.5 " 0.25 ". Each result is an average of at least 5 specimens. Results for individual tests are shown in Appendix-C, including statistical analysis of the data. Virgin polymers and recycled polymers without fibers showed significant deformations after the maximum load. Similar behavior was observed in specimens with chopped fibers. Comparison of compression stress and stiffness is shown in Figs. 4.17 and 4.18. Typical stress vs. change-in-height diagrams of $100 \%$ recycled polymer specimens without and with fibers are shown in Figs. 4.19 and 4.20.

Table 4.9 Results of Compression Tests on ABS

\begin{tabular}{|c|c|c|c|c|}
\hline Specimen & $\begin{array}{c}\text { Maximum } \\
\text { Load }\end{array}$ & $\begin{array}{c}\text { Maximum } \\
\text { Stress }\end{array}$ & $\begin{array}{c}\text { Reduction in Length } \\
\text { @ Max. Stress }\end{array}$ & $\begin{array}{c}\text { Compression Stiffness } \\
\text { (E) }\end{array}$ \\
\hline & lbs. & psi & in. & psi \\
\hline CA1 & 1120.75 & 8966.02 & 0.042 & $0.34 \mathrm{E}+06$ \\
\hline CA2 & 1641.90 & 13135.22 & 0.034 & $0.91 \mathrm{E}+06$ \\
\hline CA3 & 1099.03 & 8792.27 & 0.039 & $0.42 \mathrm{E}+06$ \\
\hline CA4 & 1861.38 & 14891.01 & 0.034 & $0.92 \mathrm{E}+06$ \\
\hline CA5 & 1121.55 & 8972.42 & 0.040 & $0.41 \mathrm{E}+06$ \\
\hline CA6 & 1740.07 & 13920.55 & 0.033 & $1.02 \mathrm{E}+06$ \\
\hline
\end{tabular}

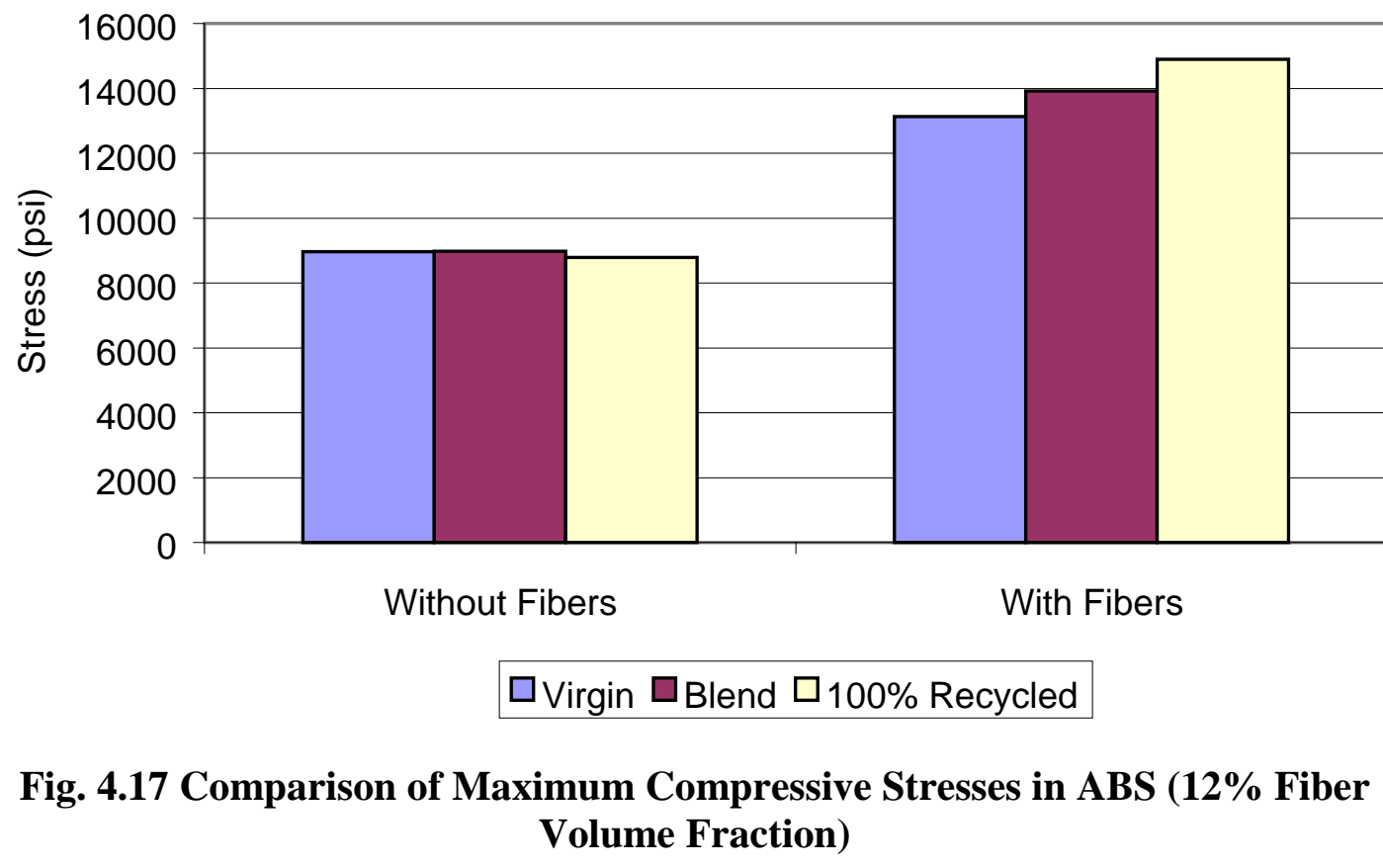




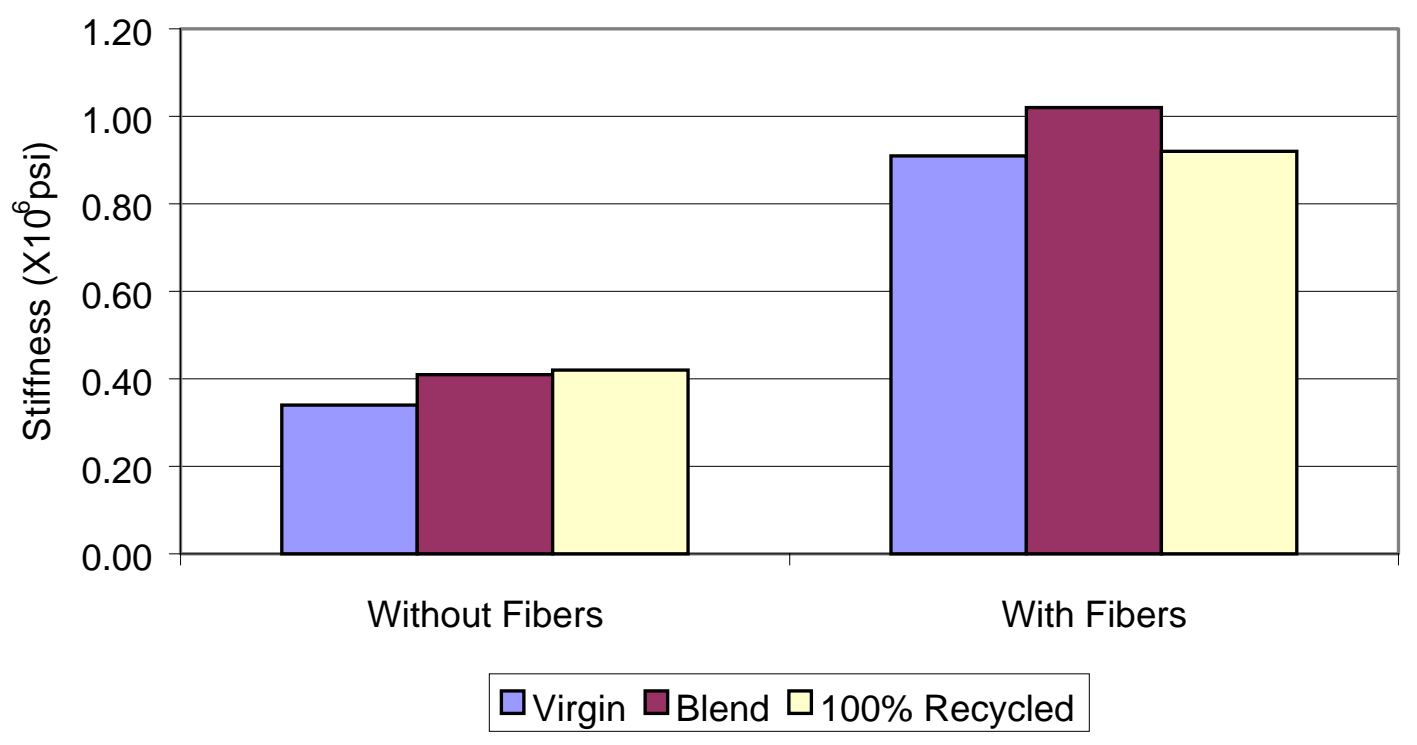

Fig. 4.18 Comparison of Maximum Compressive Stiffness in ABS (12\% Fiber Volume Fraction)

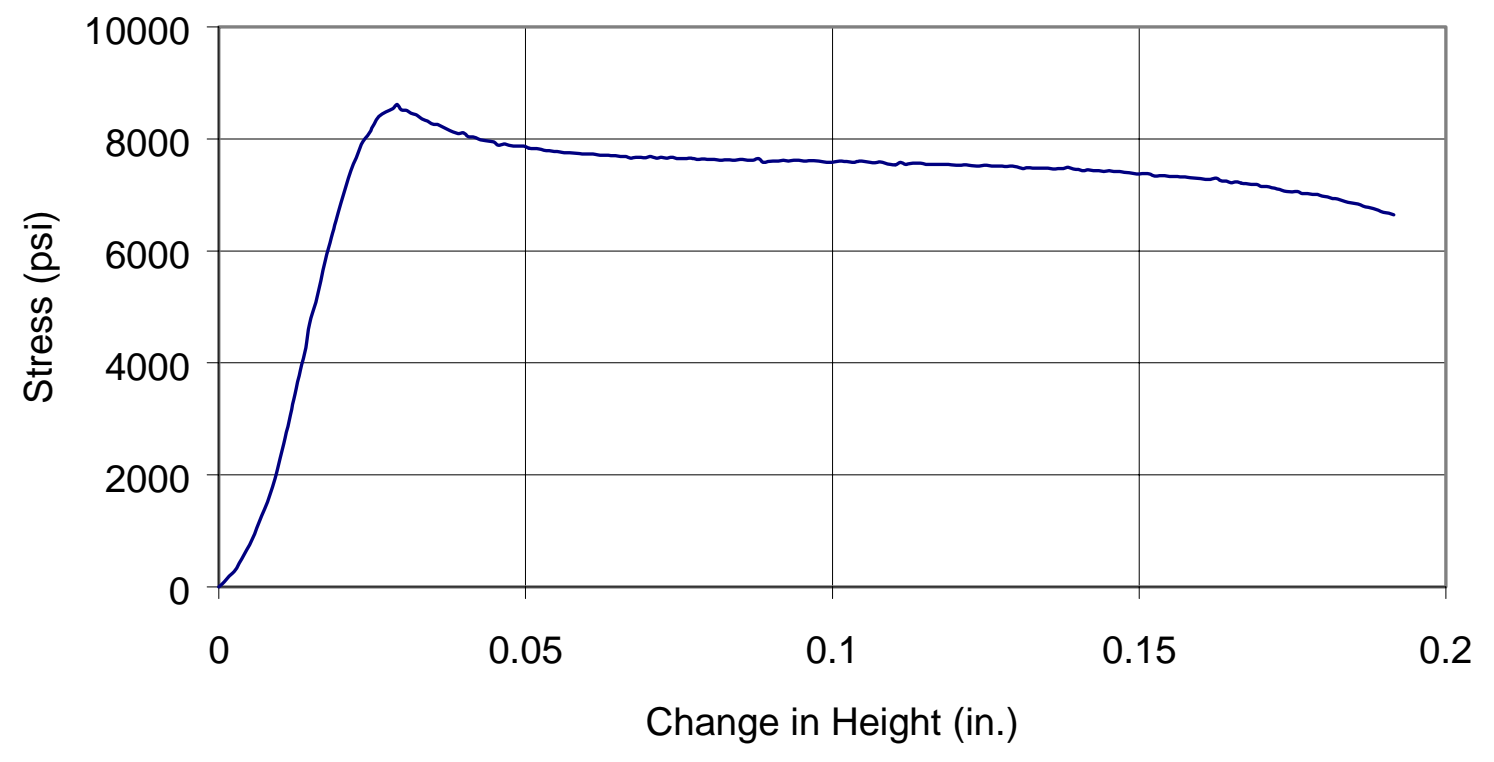

Fig. 4.19 Stress versus Change-in-Height for 100\% Recycled ABS specimen without Fibers in Compression 


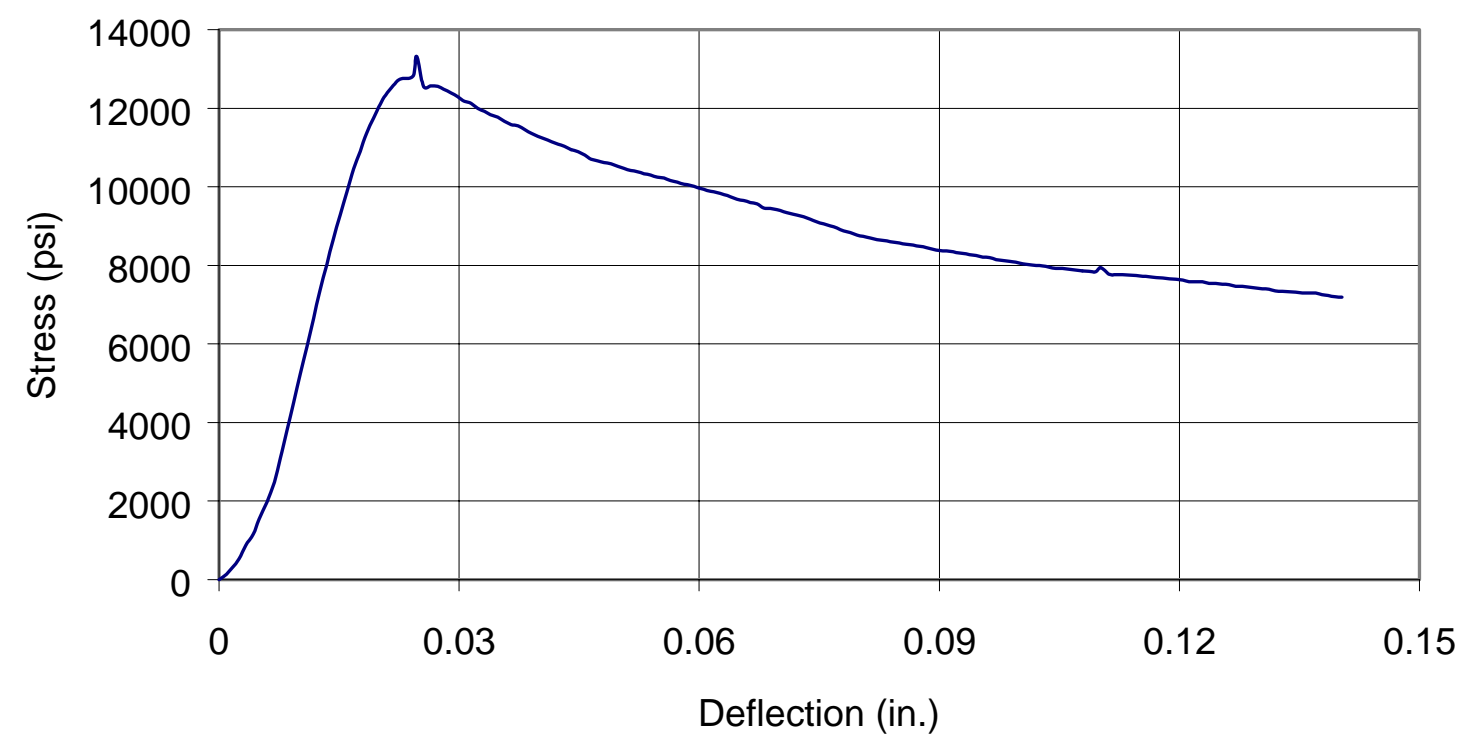

Fig. 4.20 Stress vs. Change-in-Height for 100\% Recycled ABS specimen with $12 \%$ Fiber Volume Fraction in Compression

\subsubsection{Analysis and Discussion of Compression Test Results on ABS}

Evaluation of stiffness was carried out using the slope of the stress versus changein-height diagrams in simple stress equation, and the stiffness values were found to be lower than those recorded by strain gages. In this report, stiffness values under compressive loads obtained through strain-gages are reported. Analysis of test results is shown in Table 4.10. 
Table 4.10 Analysis and Comparison of Compression Test Results on ABS (\% Increase/Decrease)

\begin{tabular}{|c|l|l|r|r|r|}
\hline Effect of & \multicolumn{1}{|c|}{$\begin{array}{c}\text { Specimen } \\
\text { Type }\end{array}$} & $\begin{array}{c}\text { Compared } \\
\text { With }\end{array}$ & $\begin{array}{c}\text { Max. Tensile } \\
\text { Stress }\end{array}$ & $\begin{array}{c}\text { Tensile } \\
\text { Stiffness }\end{array}$ & $\begin{array}{c}\text { Strain @ } \\
\text { Max. Stress }\end{array}$ \\
\hline & & & $\mathbf{\%}$ & $\mathbf{\%}$ & \% \\
\hline \multirow{2}{*}{$\begin{array}{c}\text { Recycling } \\
\text { (Without Fibers) }\end{array}$} & CA3 (R) & \multirow{2}{*}{ CA1 (V) } & -1.9 & +23.5 & -7.1 \\
\cline { 2 - 4 } & CA5 (B) & & +0.1 & +20.6 & -4.8 \\
\hline $\begin{array}{c}\text { Recycling } \\
\text { (With Fibers) }\end{array}$ & CA4 (R-F) & \multirow{2}{*}{ CA2 (V-F) } & +13.4 & +1.1 & 0.0 \\
\cline { 2 - 5 } & CA6 (B-F) & & +6.0 & +12.1 & -2.9 \\
\hline \multirow{3}{*}{ Fiber Addition } & CA2 (V-F) & CA1 (V) & +46.5 & +167.6 & -19.0 \\
\cline { 2 - 6 } & CA4 (R-F) & CA3 (R) & +66.0 & +300.0 & -15.0 \\
\cline { 2 - 6 } & CA6 (B-F) & CA5 (B) & +55.1 & +343.5 & -17.5 \\
\hline
\end{tabular}

Note: C-Compression; A-ABS; V-Virgin; R-100\% Recycled; B-Blend (80\% virgin and $20 \%$ Recycled); F-Fiber; +ve sign -Increase; -ve sign- Reduction. Refer to Table 4.9 for absolute values.

- Compared to virgin polymers, maximum compressive stress variations in the blend and $100 \%$ recycled polymers were found to be less than $2 \%$. However, blend and $100 \%$ recycled polymer stiffnesses increased by 20.6 and $23.5 \%$, respectively.

- Compared to virgin polymers with fibers, maximum compressive stress increases in the blend and 100\% recycled polymers with fibers were found to be between 6 and $13.4 \%$, respectively. Similarly, blend and $100 \%$ recycled polymer stiffness increase was found to be 12.1 and $1.1 \%$, respectively.

- Addition of $12 \%$ fiber volume fraction of randomly oriented and chopped glass fibers to virgin, blend and $100 \%$ recycled polymers resulted in compressive stress increases of $46.5,55.1$, and $66.0 \%$ respectively. Similarly, stiffness increase was found to be $167.6,343.5$ and $300.0 \%$ respectively for the virgin, blend and $100 \%$ recycled polymers. 


\subsubsection{Results of Compression Tests on PC}

Strength and stiffness results of the compression tests are summarized in Table 4.11. Each result is an average of at least 5 specimens with a height of 0.5 " and a crosssection of 0.5 "x 0.25 ". Results for individual tests are shown in Appendix-C, including statistical analysis of the data. Virgin polymers and recycled polymers without fibers showed significant deformations after the maximum load. Similar behavior was observed in specimens with chopped fibers. Readings recorded by the Instron machine were found to be $95 \%$ higher than actual readings, as verified through a set of deflection gages having a least count of $0.0001 "$ shown in Fig 4.21. It was noted that small deflections (of the order of $10^{-4}$ inches) of the stationary cross-head had a major contribution towards such discrepancy. The corrected stiffness readings were found to match with strain gage reading for $\mathrm{ABS}$, therefore it was decided to use strain gage readings for the stiffness evaluation of ABS. The stiffness values for $\mathrm{PC}$ are based on the corrected machine readings as shown in Table 4.11. Comparisons of compression stress and stiffness with and without fibers are shown in Figs. 4.22 and 4.23. Typical stress vs. change-in-height diagrams of $100 \%$ recycled polymer specimens without and with fibers is shown in Figs. 4.24 and 4.25 . The compression test was stopped between 0.03 to 0.04 inches deflection due to the specimen becoming compressed to a point that the original cross-section begins to change. 


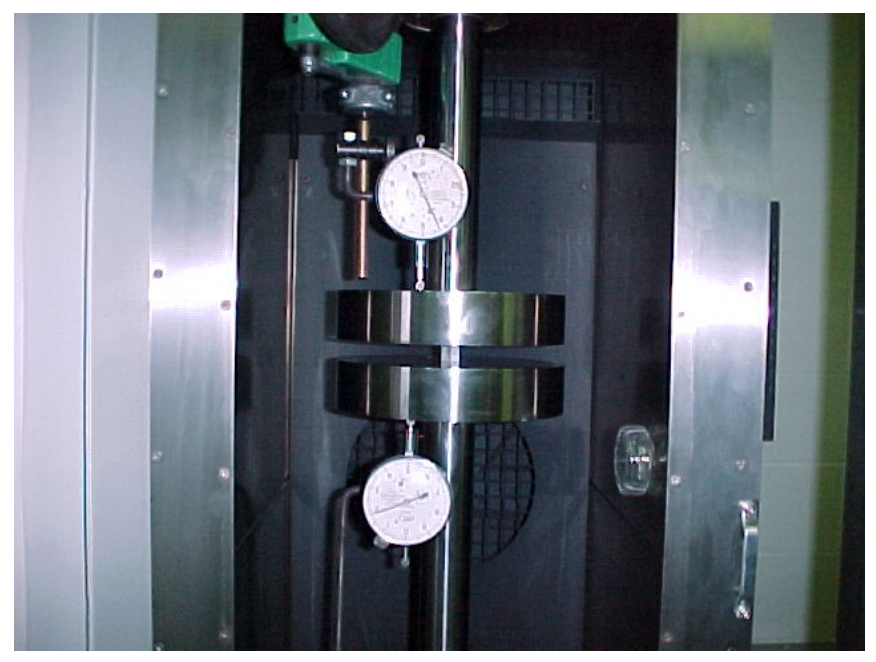

Fig. 4.21 Deflection gage set-up

Table 4.11 Results of Compression Tests on PC

\begin{tabular}{|c|c|c|c|c|}
\hline Specimen & $\begin{array}{c}\text { Maximum } \\
\text { Load }\end{array}$ & $\begin{array}{c}\text { Maximum } \\
\text { Stress }\end{array}$ & $\begin{array}{c}\text { Reduction in Length } \\
\text { @ Max. Stress }\end{array}$ & $\begin{array}{c}\text { Compression Stiffness } \\
\text { (E) }\end{array}$ \\
\hline & lbs. & psi & in. & psi \\
\hline CP1 & 1302.96 & 10423.66 & 0.043 & $0.41 \mathrm{E}+06$ \\
\hline CP2 & 2541.60 & 20332.83 & 0.040 & $0.80 \mathrm{E}+06$ \\
\hline CP3 & 1288.91 & 10311.28 & 0.044 & $0.39 \mathrm{E}+06$ \\
\hline CP4 & 2593.40 & 20747.23 & 0.037 & $0.84 \mathrm{E}+06$ \\
\hline CP5 & 1315.49 & 10523.94 & 0.044 & $0.41 \mathrm{E}+06$ \\
\hline CP6 & 2640.52 & 21124.14 & 0.038 & $0.83 \mathrm{E}+06$ \\
\hline
\end{tabular}




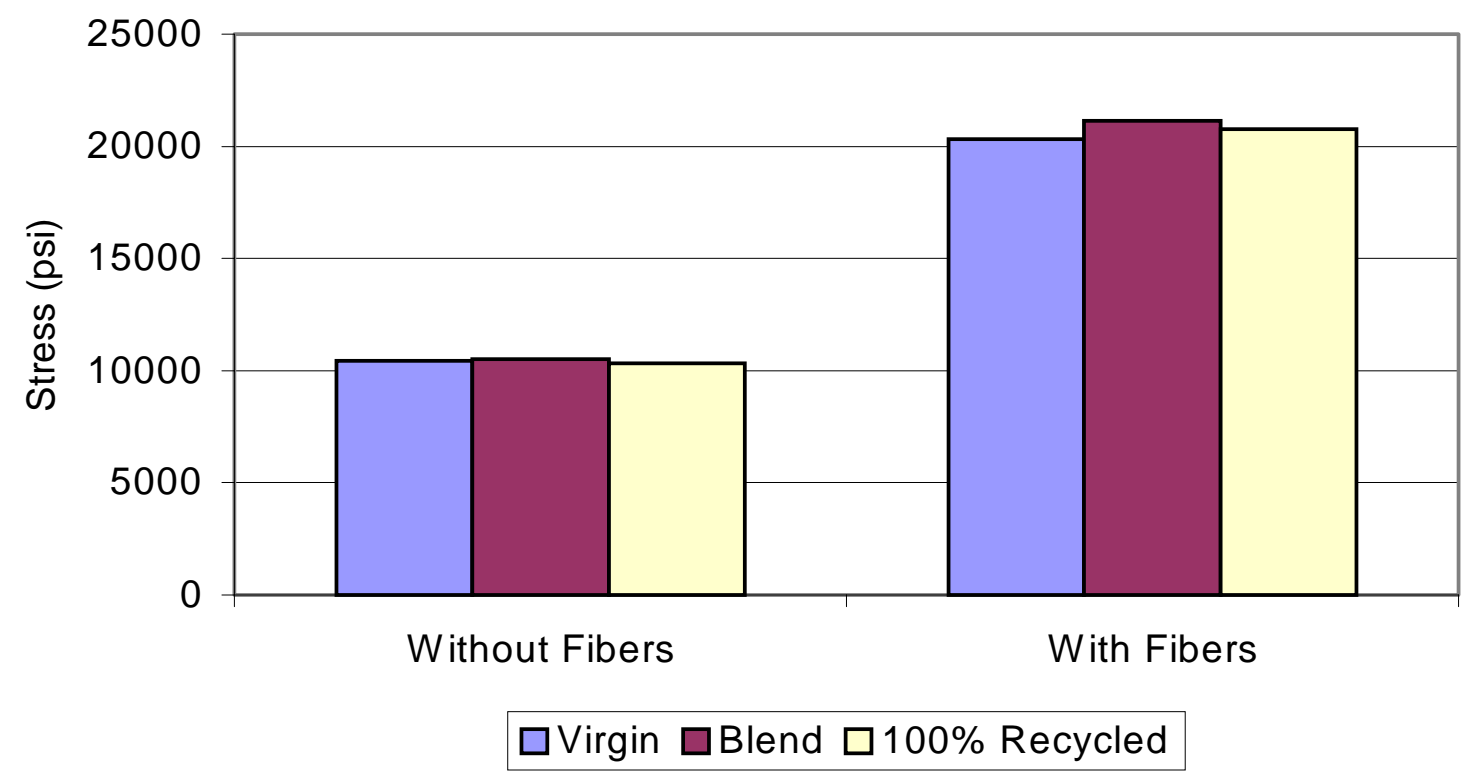

Fig. 4.22 Comparison of Maximum Compressive Stresses in PC (12\% Fiber Volume Fraction)

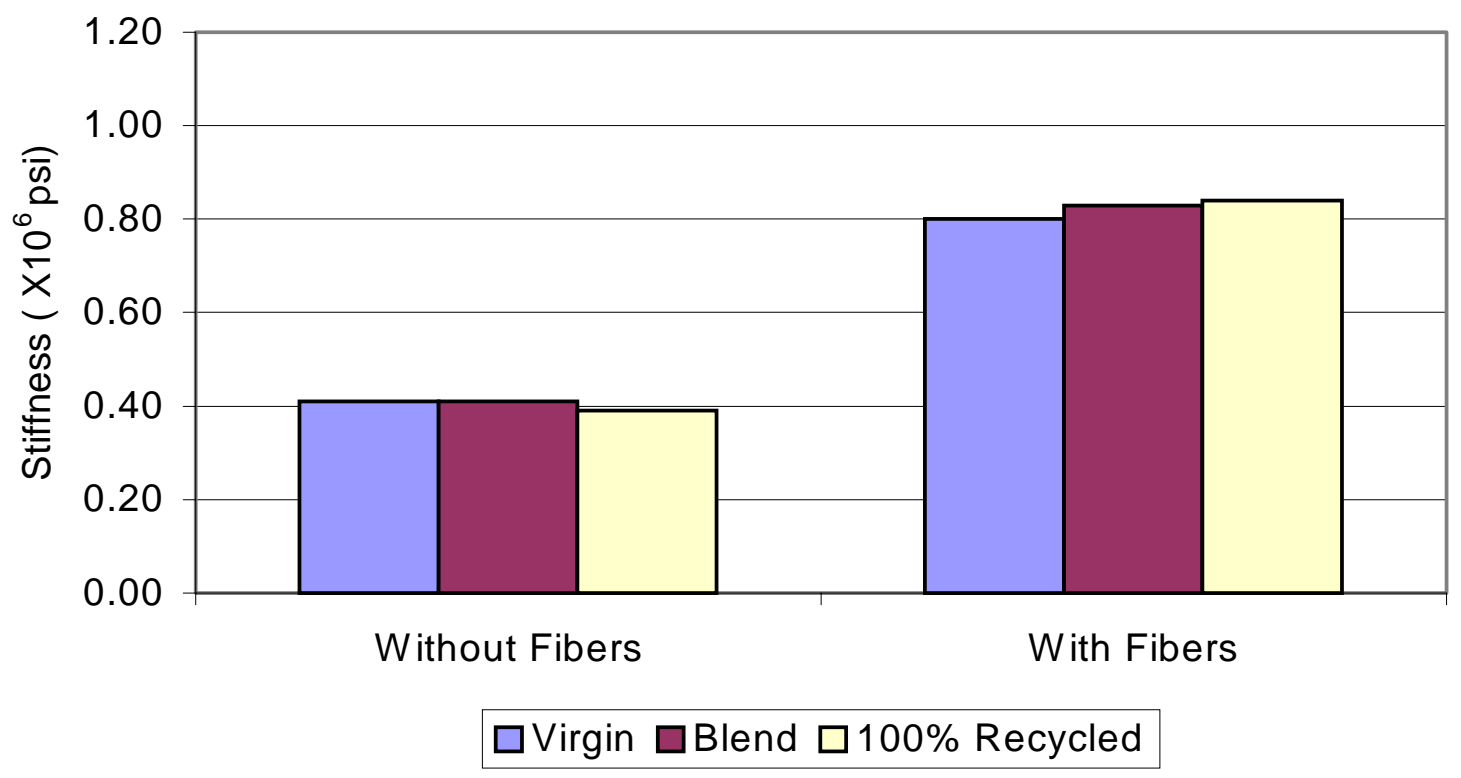

Fig. 4.23 Comparison of Maximum Compressive Stiffness in PC (12\% Fiber Volume Fraction) 


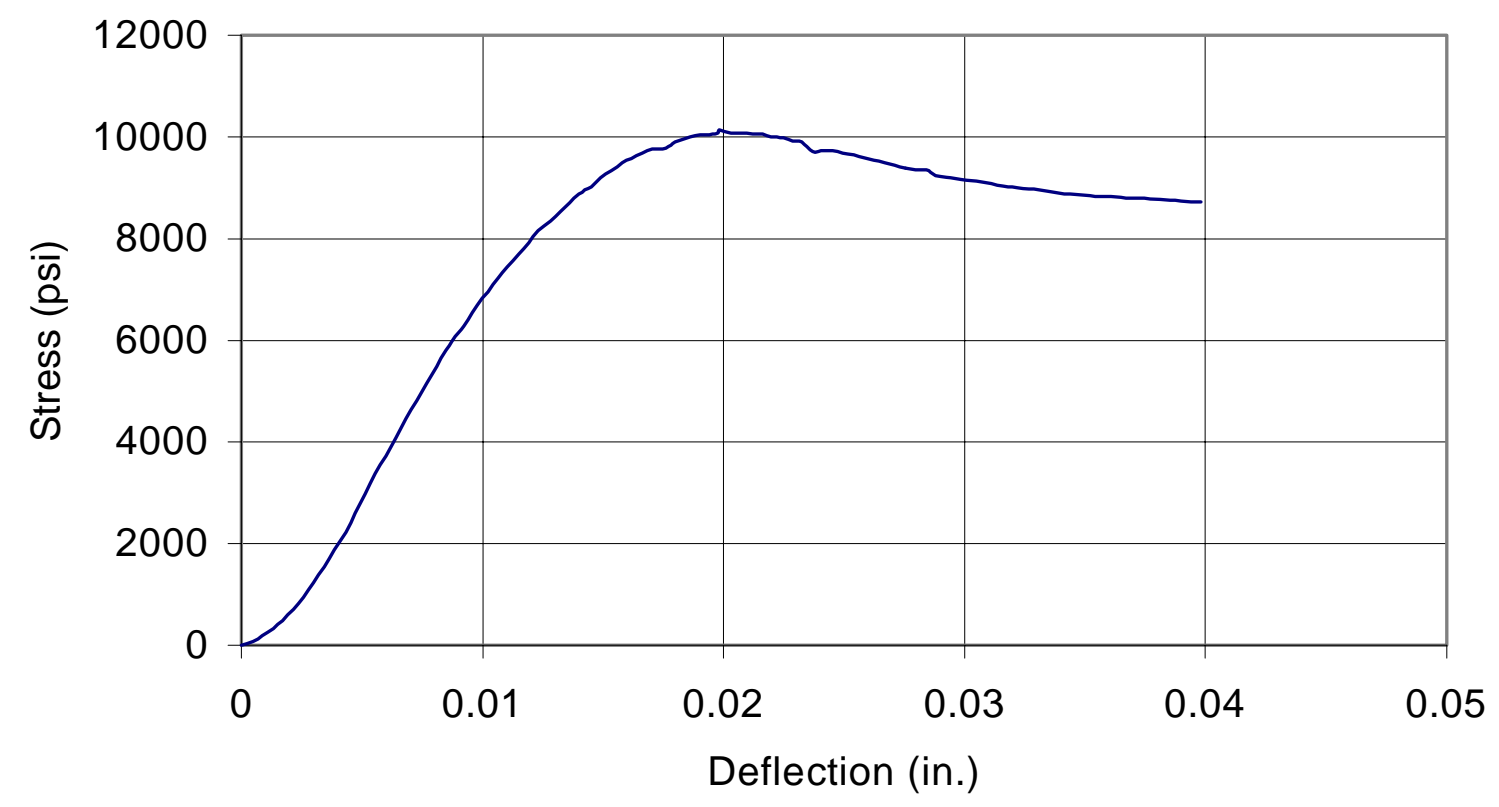

Fig. 4.24 Stress versus Change-in-Height for $100 \%$ Recycled PC specimen without Fibers in Compression

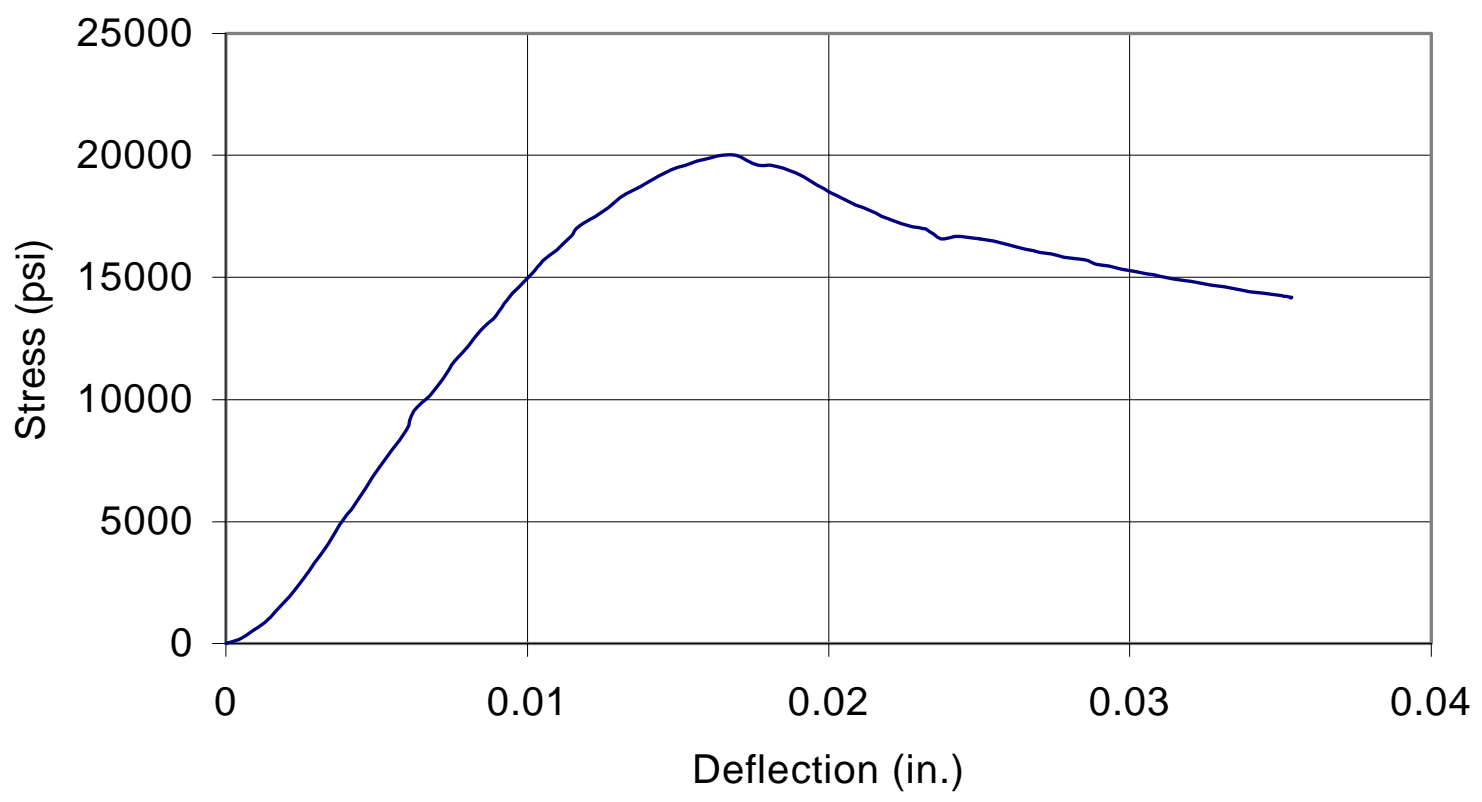

Fig. 4.25 Stress versus Change-in-Height for $100 \%$ Recycled PC specimen with $12 \%$ Fiber Volume Fraction in Compression 


\subsubsection{Analysis and Discussion of Compression Test Results on PC}

Evaluation of stiffness was carried out using the slope of the stress versus corrected change-in-height diagrams. Analysis of test results is shown in Table 4.12.

Table 4.12 Analysis and Comparison of Compression Test Results on PC (\% Increase/Decrease)

\begin{tabular}{|c|c|c|c|c|c|}
\hline Effect of & $\begin{array}{c}\text { Specimen } \\
\text { Type } \\
\end{array}$ & $\begin{array}{c}\text { Compared } \\
\text { With }\end{array}$ & $\begin{array}{c}\text { Max. Tensile } \\
\text { Stress } \\
\end{array}$ & $\begin{array}{c}\text { Tensile } \\
\text { Stiffness }\end{array}$ & $\begin{array}{c}\text { Strain@ } \\
\text { Max.Stress }\end{array}$ \\
\hline & & & $\%$ & $\%$ & $\%$ \\
\hline \multirow{2}{*}{$\begin{array}{c}\text { Recycling } \\
\text { (Without Fibers) }\end{array}$} & CP3 (R) & \multirow{2}{*}{ CP1 (V) } & -1.1 & -4.8 & +2.3 \\
\hline & CP5 (B) & & +1.0 & 0.0 & +2.3 \\
\hline \multirow{2}{*}{$\begin{array}{c}\text { Recycling } \\
\text { (With Fibers) }\end{array}$} & CP4 (R-F) & \multirow{2}{*}{ CP2 (V-F) } & +2.0 & +5.0 & -7.5 \\
\hline & CP6 (B-F) & & +3.9 & +3.8 & -5.0 \\
\hline \multirow{3}{*}{ Fiber Addition } & CP2 (V-F) & CP1 (V) & +95.1 & +95.1 & -7.0 \\
\hline & CP4 (R-F) & CP3 (R) & +101.2 & +115.4 & -15.9 \\
\hline & CP6 (B-F) & CP5 (B) & +100.7 & +102.4 & -13.6 \\
\hline
\end{tabular}

Note: C-Compression; P-PC; V-Virgin; R-100\% Recycled; B-Blend (80\% virgin and $20 \%$ Recycled); F-Fiber; +ve sign -Increase; -ve sign- Reduction. Refer to Table 4.11 for absolute values.

- Compared to virgin polymers, maximum compressive stress variations in the blend and $100 \%$ recycled polymers were found to be less than $1.5 \%$. However, $100 \%$ recycled polymer stiffnesses decreased by $4.8 \%$ whereas the blend was unchanged.

- Compared to virgin polymers with fibers, maximum compressive stress increases in the blend and 100\% recycled polymers with fibers were found to be between 3.9 and $2.0 \%$, respectively. Similarly, blend and $100 \%$ recycled polymer specimen stiffness increases were found to be 3.8 and $5.0 \%$, respectively. 
- Addition of $12 \%$ fiber volume fraction of randomly oriented and chopped glass fibers to virgin, blend and $100 \%$ recycled polymers resulted in compressive stress increases of $95.1,100.7$, and $101.2 \%$ respectively. Similarly, stiffness increase was found to be 95.1, 102.4 and $115.4 \%$ respectively for the virgin, blend and $100 \%$ recycled polymers.

- Compared to the ABS polymer without fibers, the virgin, blend and $100 \%$ recycled PC polymer without fibers exhibited 14.0, 14.7, and 14.7\% higher maximum stress readings with similar deflections at maximum stress, respectively.

- Compared to the ABS polymer with fibers, the virgin, blend and $100 \%$ recycled PC polymer with fibers exhibited $35.4,34.1$, and $28.2 \%$ higher maximum stress readings with similar deflections at maximum stress, respectively.

\subsection{Impact Test}

\subsubsection{Results, Analysis, and Discussion of Impact Tests on ABS}

Impact strength results are summarized in Table 4.13 after averaging data of at least 5 specimens tested at a laboratory temperature of $72^{\circ} \mathrm{F}$. Results for individual tests are shown in Appendix-D, including statistical analysis of the data. Virgin polymers and recycled polymers without fibers showed higher impact strength than those with fibers. Comparison of impact strength is shown in Fig. 4.26. Analysis of the test results is shown in Table 4.14. 
Table 4.13 Results of Impact Tests on ABS

\begin{tabular}{|c|c|c|c|c|}
\hline Specimen & $\begin{array}{c}\text { Indicated } \\
\text { Impact Strength }\end{array}$ & $\begin{array}{c}\text { Corrected } \\
\text { Impact Strength }\end{array}$ & $\begin{array}{c}\text { Corrected } \\
\text { Impact Strength }\end{array}$ & $\begin{array}{c}\text { Observed } \\
\text { Failure Types }\end{array}$ \\
\hline & $\mathrm{ft}-l \mathrm{bs}_{\mathrm{f}}$ & $\mathrm{ft}-l \mathrm{bs}_{\mathrm{f}}$ & $\mathrm{ft}_{\mathrm{f}} \mathrm{lbs}_{\mathrm{f}} / \mathrm{in}$ & \\
\hline $\mathrm{IA} 1$ & 0.48 & 0.44 & 3.49 & $\mathrm{H}$ \\
\hline IA2 & 0.25 & 0.20 & 1.58 & $\mathrm{C}$ \\
\hline IA3 & 0.31 & 0.27 & 2.17 & $\mathrm{H}$ \\
\hline IA4 & 0.17 & 0.12 & 0.96 & $\mathrm{C}$ \\
\hline IA5 & 0.34 & 0.30 & 2.38 & $\mathrm{H}(3), \mathrm{C}(2)$ \\
\hline IA6 & 0.20 & 0.15 & 1.20 & $\mathrm{C}$ \\
\hline
\end{tabular}

Note: H-Hinge Break; C-Complete Break; corrections applied as per the chart supplied by the manufacturer for the impact testing machine to account for friction and windage.

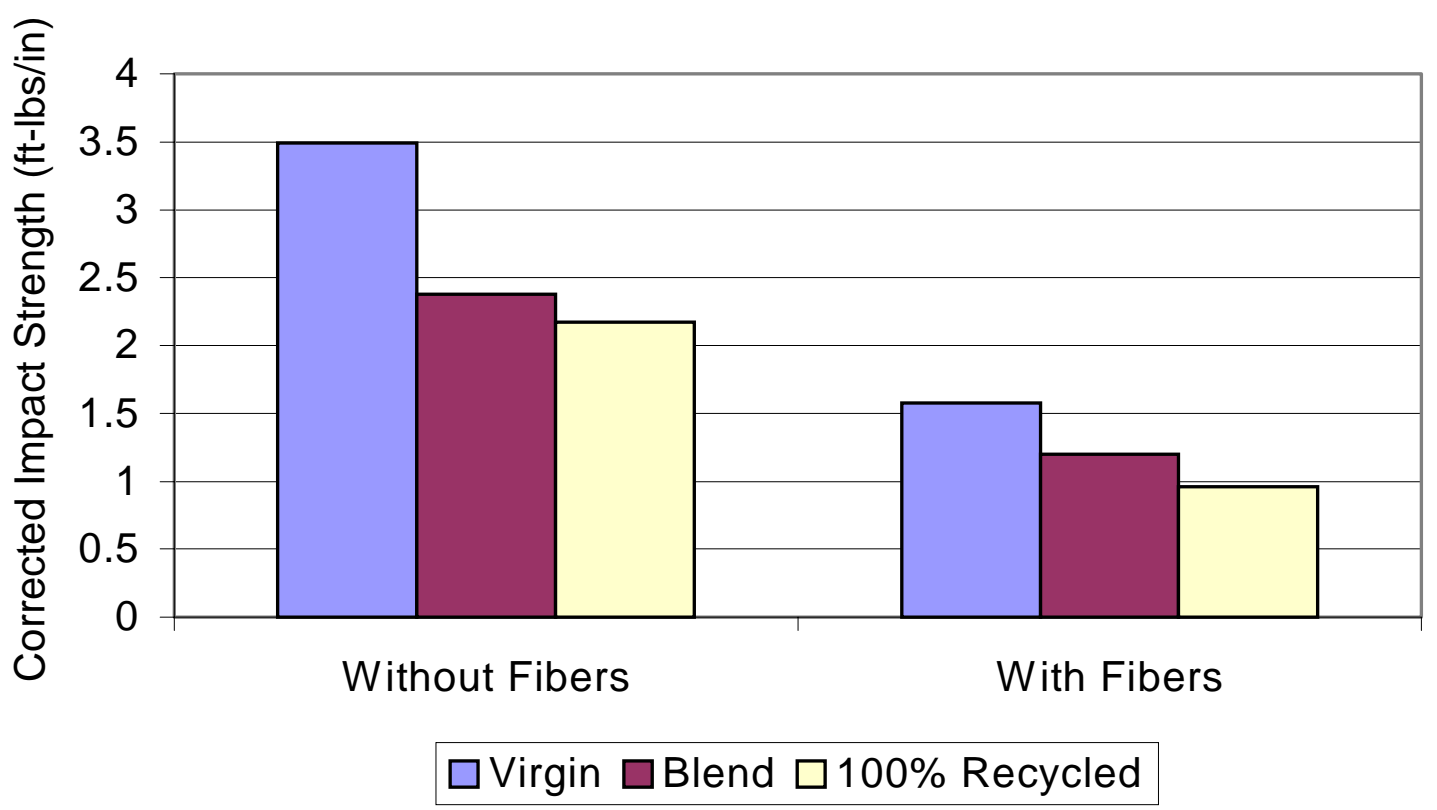

Fig. 4.26 Comparison of Impact Strength in ABS (12\% Fiber Volume Fraction) 
Table 4.14 Analysis and Comparison of Impact Test Results on ABS (\% Increase/Decrease)

\begin{tabular}{|c|l|l|c|}
\hline Effect of & Specimen Type & $\begin{array}{c}\text { Compared } \\
\text { with }\end{array}$ & Impact Strength \\
\hline & & & \% \\
\hline \multirow{2}{*}{$\begin{array}{c}\text { Recycling } \\
\text { (Without Fibers) }\end{array}$} & IA3 (R) & \multirow{2}{*}{ IA1 (V) } & -37.8 \\
\hline & IA5 (B) & & -31.8 \\
\hline $\begin{array}{c}\text { Recycling } \\
\text { (With Fibers) }\end{array}$ & IA4 (R-F) & \multirow{2}{*}{ IA2 (V-F) } & -39.2 \\
\cline { 2 - 4 } & IA6 (B-F) & & -24.1 \\
\hline \multirow{2}{*}{ Fiber Addition } & IA2 (V-F) & IA1 (V) & -54.7 \\
\cline { 2 - 4 } & IA4 (R-F) & IA3 (R) & -59.7 \\
\cline { 2 - 4 } & IA6 (B-F) & IA5 (B) & -49.6 \\
\hline
\end{tabular}

Note: I-Impact; A-ABS; V-Virgin; R-100\% Recycled; B-Blend (80\% virgin and 20\% Recycled); F-Fiber; +ve sign -Increase; -ve sign- Reduction. For absolute values refer to Table 4.13.

- Compared to virgin polymers, impact strength of the blend and $100 \%$ recycled polymers decreased by $31.8 \%$ and $37.8 \%$ respectively.

- Compared to virgin polymers with fibers, maximum impact strength reductions in the blend and $100 \%$ recycled polymers with fibers were found to be 24.1 and $39.2 \%$, respectively.

- Addition of $25 \%$ by weight of randomly oriented and chopped glass fibers to virgin, blend and $100 \%$ recycled polymers resulted in impact strength reduction of 54.7 , 49.6, and $59.7 \%$.

\subsubsection{Results, Analysis, and Discussion of Impact Tests on PC}

Impact strength results are summarized in Table 4.15 after averaging data of at least 5 specimens tested at a laboratory temperature of $72^{0} \mathrm{~F}$. Results for individual tests are shown in Appendix-D, including statistical analysis of the data. Virgin polymers and 
recycled polymers without fibers showed higher impact strength than those with fibers. Comparison of impact strength is shown in Fig. 4.27. Analysis of the test results is shown in Table 4.16.

Table 4.15 Results of Impact Tests on PC

\begin{tabular}{|c|c|c|c|c|}
\hline Specimen & $\begin{array}{c}\text { Indicated } \\
\text { Impact Strength }\end{array}$ & $\begin{array}{c}\text { Corrected } \\
\text { Impact Strength }\end{array}$ & $\begin{array}{c}\text { Corrected } \\
\text { Impact Strength }\end{array}$ & $\begin{array}{c}\text { Observed } \\
\text { Failure Types }\end{array}$ \\
\hline & $\mathrm{ft}-l \mathrm{bs}_{\mathrm{f}}$ & $\mathrm{ft}^{-l \mathrm{bs}} \mathrm{f}_{\mathrm{f}}$ & $\mathrm{ft}-\mathrm{lbs} / \mathrm{in}$ & \\
\hline $\mathrm{IP} 1$ & 1.79 & 1.77 & 14.40 & $\mathrm{P}$ \\
\hline $\mathrm{IP} 2$ & 0.42 & 0.38 & 3.01 & $\mathrm{C}(4), \mathrm{H}(1)$ \\
\hline $\mathrm{IP} 3$ & 1.71 & 1.69 & 13.53 & $\mathrm{P}$ \\
\hline IP4 & 0.27 & 0.23 & 1.81 & $\mathrm{C}$ \\
\hline IP5 & 1.87 & 1.85 & 14.80 & $\mathrm{P}$ \\
\hline IP6 & 0.37 & 0.33 & 2.67 & $\mathrm{C}$ \\
\hline
\end{tabular}

Note: H-Hinge Break; C-Complete Break; P-Partial Break corrections applied as per the chart supplied by the manufacturer for the impact testing machine to account for friction and windage.

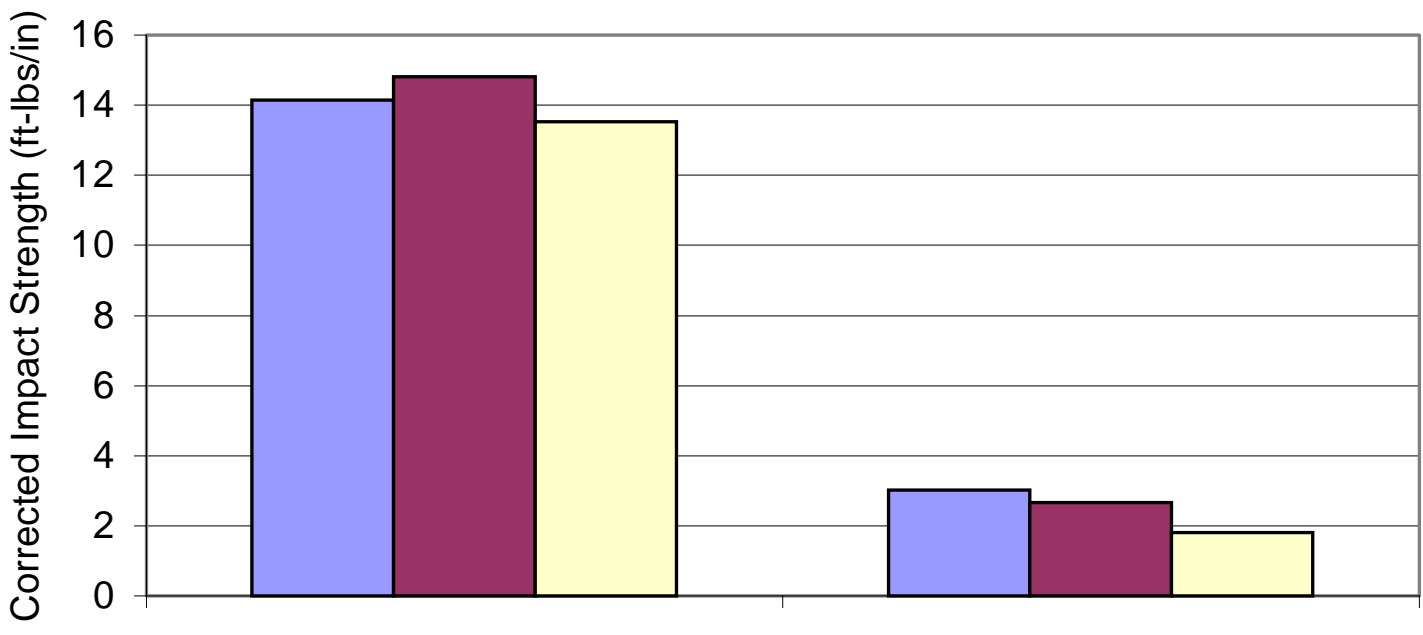

Without Fibers

With Fibers

$\square$ Virgin $\square$ Blend $\square 100 \%$ Recycled

Fig. 4.27 Comparison of Impact Strength in PC (12\% Fiber Volume Fraction) 
Table 4.16 Analysis and Comparison of Impact Test Results on PC (\% Increase/Decrease)

\begin{tabular}{|c|l|l|c|}
\hline Effect of & Specimen Type & $\begin{array}{c}\text { Compared } \\
\text { with }\end{array}$ & Impact Strength \\
\hline & & & $\%$ \\
\hline \multirow{2}{*}{$\begin{array}{c}\text { Recycling } \\
\text { (Without Fibers) }\end{array}$} & IP3 (R) & \multirow{2}{*}{ IP1 (V) } & -4.4 \\
\hline \multirow{2}{*}{$\begin{array}{l}\text { Recycling } \\
\text { (With Fibers) }\end{array}$} & IP4 (B-F) & \multirow{2}{*}{ IP2 (V-F) } & +4.5 \\
\cline { 2 - 4 } & IP6 (B-F) & & -39.9 \\
\hline \multirow{3}{*}{ Fiber Addition } & IP2 (V-F) & IP1 (V) & -11.3 \\
\cline { 2 - 4 } & IP4 (R-F) & IP3 (R) & -78.7 \\
\cline { 2 - 4 } & IP6 (B-F) & IP5 (B) & -86.6 \\
\hline
\end{tabular}

Note: I-Impact; P-PC; V-Virgin; R-100\% Recycled; B-Blend (80\% virgin and 20\% Recycled); F-Fiber; +ve sign -Increase; -ve sign- Reduction. For absolute values refer to Table 4.15.

- Compared to virgin polymers, impact strengths of the $100 \%$ recycled polymers and the blend were nearly the same, varying by as little as $4.5 \%$.

- Compared to virgin polymers with fibers, maximum impact strength reductions in the blend and $100 \%$ recycled polymers with fibers were found to be 11.3 and $39.9 \%$, respectively.

- Addition of $12 \%$ fiber volume fraction of randomly oriented and chopped glass fibers to virgin, blend and $100 \%$ recycled polymers resulted in impact strength reduction of 78.7, 82.0, and 86.6\%.

- Compared to the ABS polymer without fibers, the virgin, blend and $100 \%$ recycled PC polymer without fibers exhibited 75.3, 84.0, and 83.9\% higher impact readings, respectively. 
- Compared to the ABS polymer with fibers, the virgin, blend and $100 \%$ recycled PC polymer with fibers exhibited 47.5, 55.1, and 47.0\% higher impact readings, respectively.

\subsection{Hardness Test}

\subsubsection{Results, Analysis, and Discussion of Hardness Tests on ABS}

Hardness test results are summarized in Table 4.17. Each result is an average of 8 specimens carried out at a laboratory temperature of $72^{\circ} \mathrm{F}$. Results for individual tests are shown in Appendix-E, including statistical analysis of the data. Comparison of the hardness values using no weight and using a $626 \mathrm{~g}$ weight is shown if Figs. 4.28 and 4.29, respectively. All results are within $1.2 \%$ using a $626 \mathrm{~g}$ weight, and $4 \%$ without the weight. Analysis of test results is shown in Table 4.18.

Table 4.17 Results of Hardness Tests on ABS

\begin{tabular}{|c|c|c|}
\hline Specimen & Without Weight & With 626g Weight \\
\hline & & \\
\hline HA1 & 10.9 & 25.7 \\
\hline HA2 & 11.3 & 25.8 \\
\hline HA3 & 11.1 & 25.6 \\
\hline HA4 & 11.2 & 25.7 \\
\hline HA5 & 11.2 & 25.9 \\
\hline HA6 & 11.2 & 25.8 \\
\hline
\end{tabular}




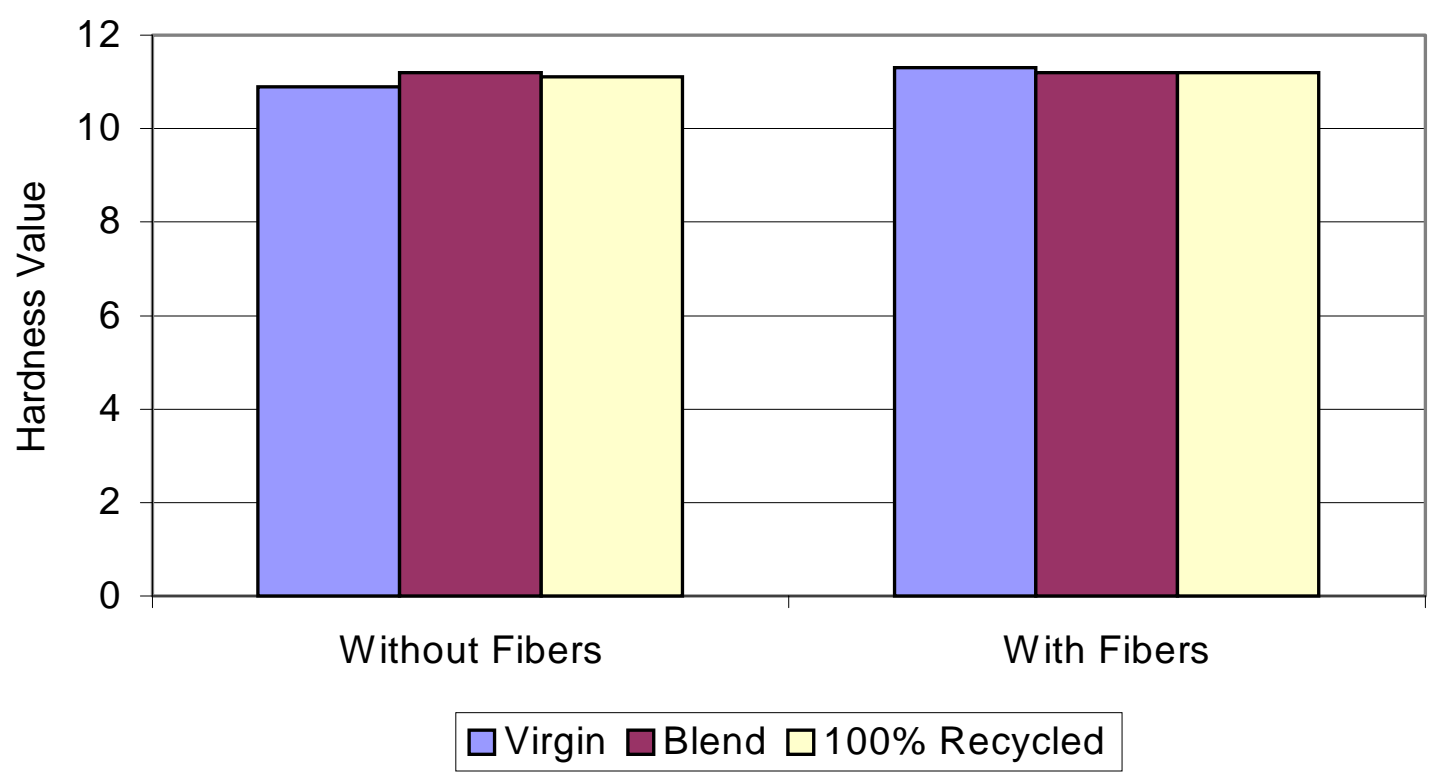

Fig. 4.28 Comparison of Hardness Values of ABS w/o Weight (12\% Fiber Volume Fraction)

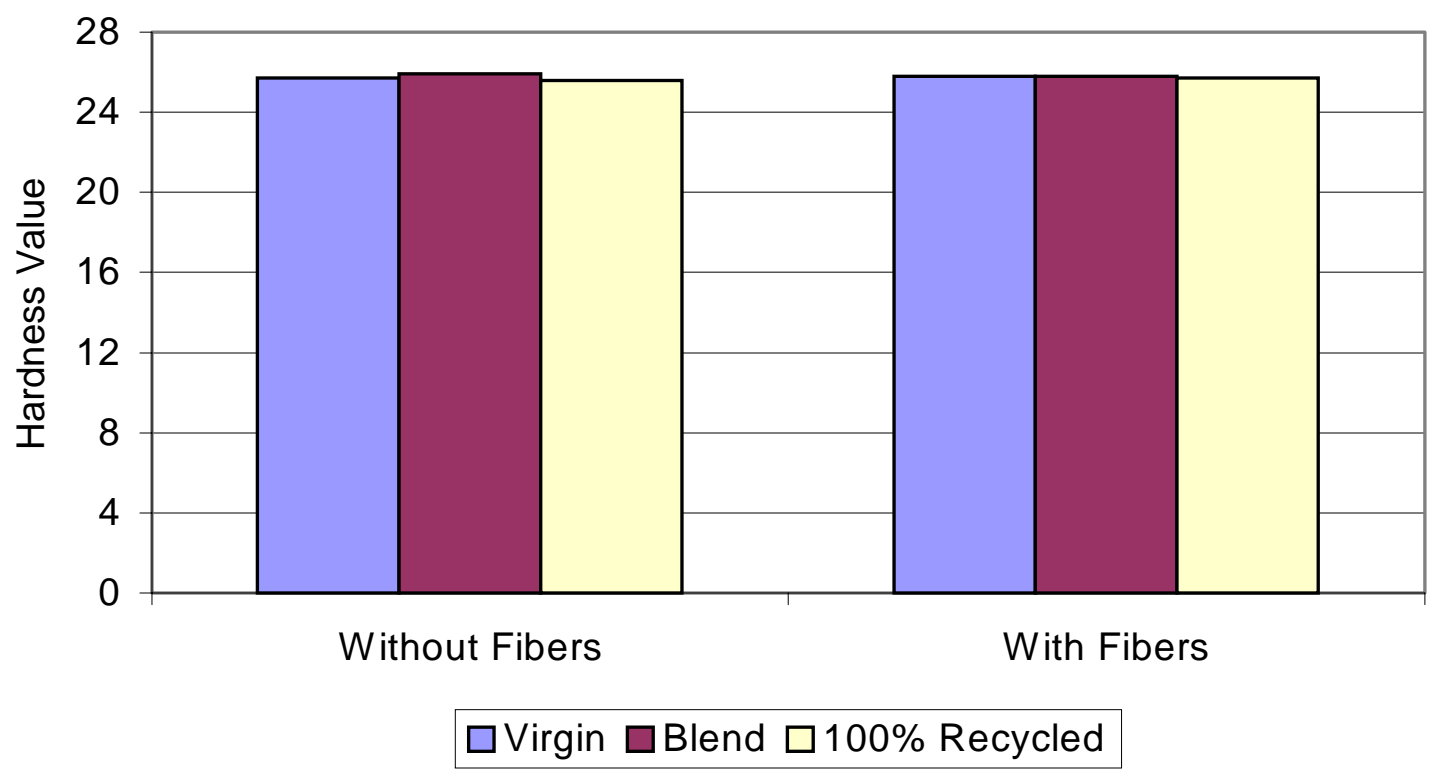

Fig. 4.29 Comparison of Hardness Values of ABS with 626g Weight (12\% Fiber Volume Fraction) 
Table 4.18 Analysis and Comparison of Hardness Test Results on ABS

(\% Increase/Decrease)

\begin{tabular}{|c|l|l|c|c|}
\hline Effect of & \multicolumn{1}{|c|}{$\begin{array}{c}\text { Specimen } \\
\text { Type }\end{array}$} & $\begin{array}{c}\text { Compared } \\
\text { with }\end{array}$ & $\begin{array}{c}\text { Without } \\
\text { Weight }\end{array}$ & $\begin{array}{c}\text { With 626g } \\
\text { Weight }\end{array}$ \\
\hline & & & \% & \% \\
\hline \multirow{2}{*}{$\begin{array}{c}\text { Recycling } \\
\text { (Without Fibers) }\end{array}$} & HA3 (R) & \multirow{2}{*}{ HA1 (V) } & +1.8 & -0.4 \\
\cline { 2 - 3 } & HA5 (B) & & +2.8 & +0.8 \\
\hline $\begin{array}{c}\text { Recycling } \\
\text { (With Fibers) }\end{array}$ & HA4 (R-F) & \multirow{2}{*}{ HA2 (V-F) } & -0.9 & -0.4 \\
\cline { 2 - 4 } & HA6 (B-F) & & -0.9 & 0.0 \\
\hline \multirow{2}{*}{ Fiber Addition } & HA2 (V-F) & HA1 (V) & +3.7 & +0.4 \\
\cline { 2 - 5 } & HA4 (R-F) & HA3 (R) & +0.9 & +0.4 \\
\cline { 2 - 5 } & HA6 (B-F) & HA5 (B) & 0.0 & -0.4 \\
\hline
\end{tabular}

Note: H-Hardness; A-ABS; V-Virgin; R-100\% Recycled; B-Blend (80\% virgin and $20 \%$ Recycled); F-Fiber; +ve sign -Increase; -ve sign- Reduction. For absolute values refer to Table 4.17 .

- Compared to virgin polymers, hardness values of the blend and $100 \%$ recycled polymers increased by 2.8 and $1.8 \%$ respectively, using no weight. The hardness value of the $100 \%$ recycled polymer decreased by $0.4 \%$ whereas the blend increased by $0.8 \%$ using the $626 \mathrm{~g}$ weight.

- Compared to virgin polymers with fibers, hardness values of the blend and $100 \%$ recycled polymers decreased by $0.9 \%$ using no weight, whereas the $100 \%$ recycled decreased by $0.4 \%$ and the blend remained unchanged using the $626 \mathrm{~g}$ weight.

- Addition $12 \%$ fiber volume fraction of randomly oriented and chopped glass fibers to virgin, blend and $100 \%$ recycled polymers resulted in hardness values increasing $3.7 \%, 0.9 \%$ and remaining unchanged respectively, using no weight. Using the $626 \mathrm{~g}$ weight, the virgin and $100 \%$ recycled increased $0.4 \%$, and the blend decreased $0.4 \%$. 


\subsubsection{Results, Analysis, and Discussion of Hardness Tests on PC}

Hardness test results are summarized in Table 4.19. Each result is an average of 8 specimens carried out at a laboratory temperature of $72^{\circ} \mathrm{F}$. Results for individual tests are shown in Appendix-E, including statistical analysis of the data. Comparison of the hardness values using no weight and using a $626 \mathrm{~g}$ weight is shown if Figs. 4.30 and 4.31, respectively. All results are within $1.0 \%$ with and without using a $626 \mathrm{~g}$ weight. Analysis of test results is shown in Table 4.20.

Table 4.19 Results of Hardness Test on PC

\begin{tabular}{|c|c|c|}
\hline Specimen & Without Weight & With 626g Weight \\
\hline & & \\
\hline HP1 & 10.6 & 25.3 \\
\hline HP2 & 10.7 & 25.3 \\
\hline HP3 & 10.6 & 25.4 \\
\hline HP4 & 10.7 & 25.3 \\
\hline HP5 & 10.7 & 25.5 \\
\hline HP6 & 10.7 & 25.5 \\
\hline
\end{tabular}




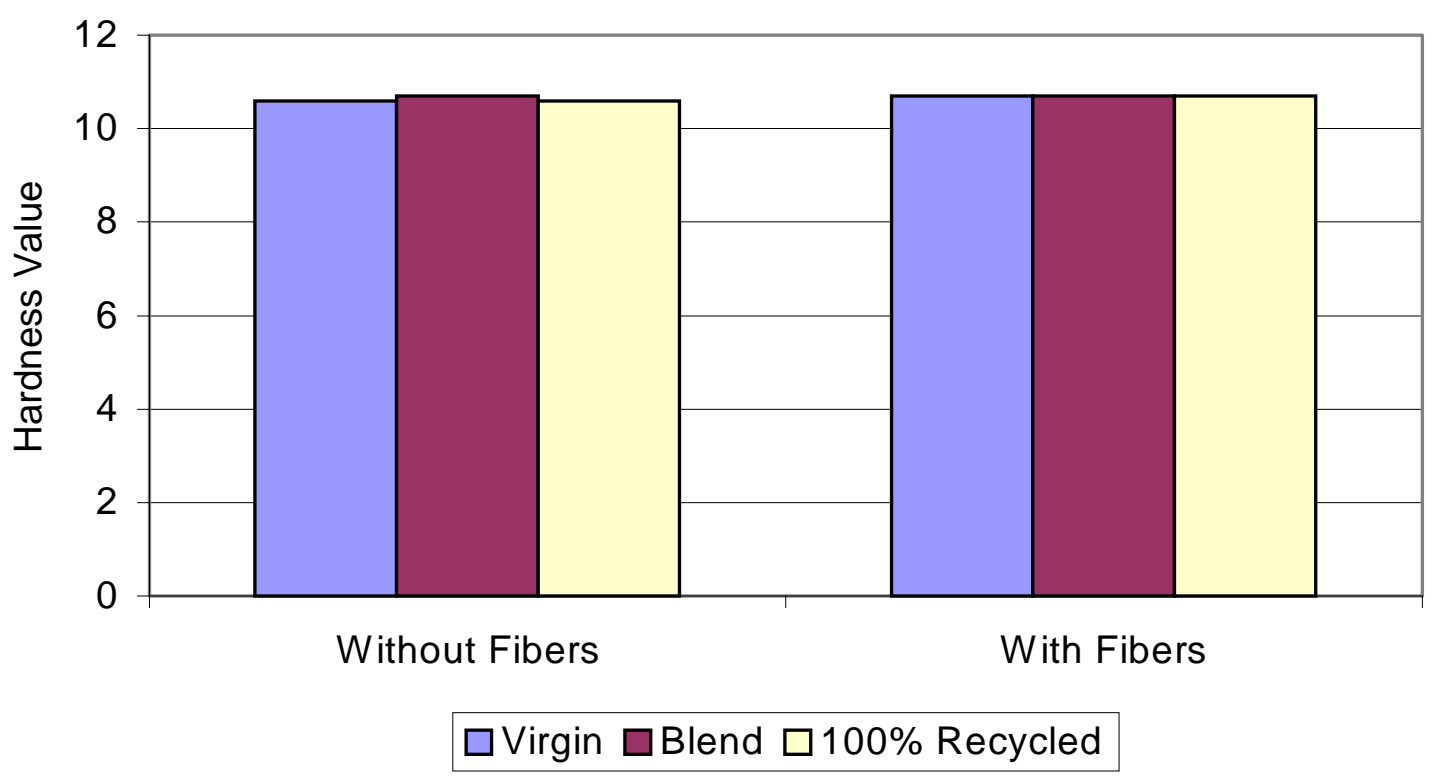

Fig. 4.30 Comparison of Hardness Values of PC w/o Weight (12\% Fiber Volume Fraction)

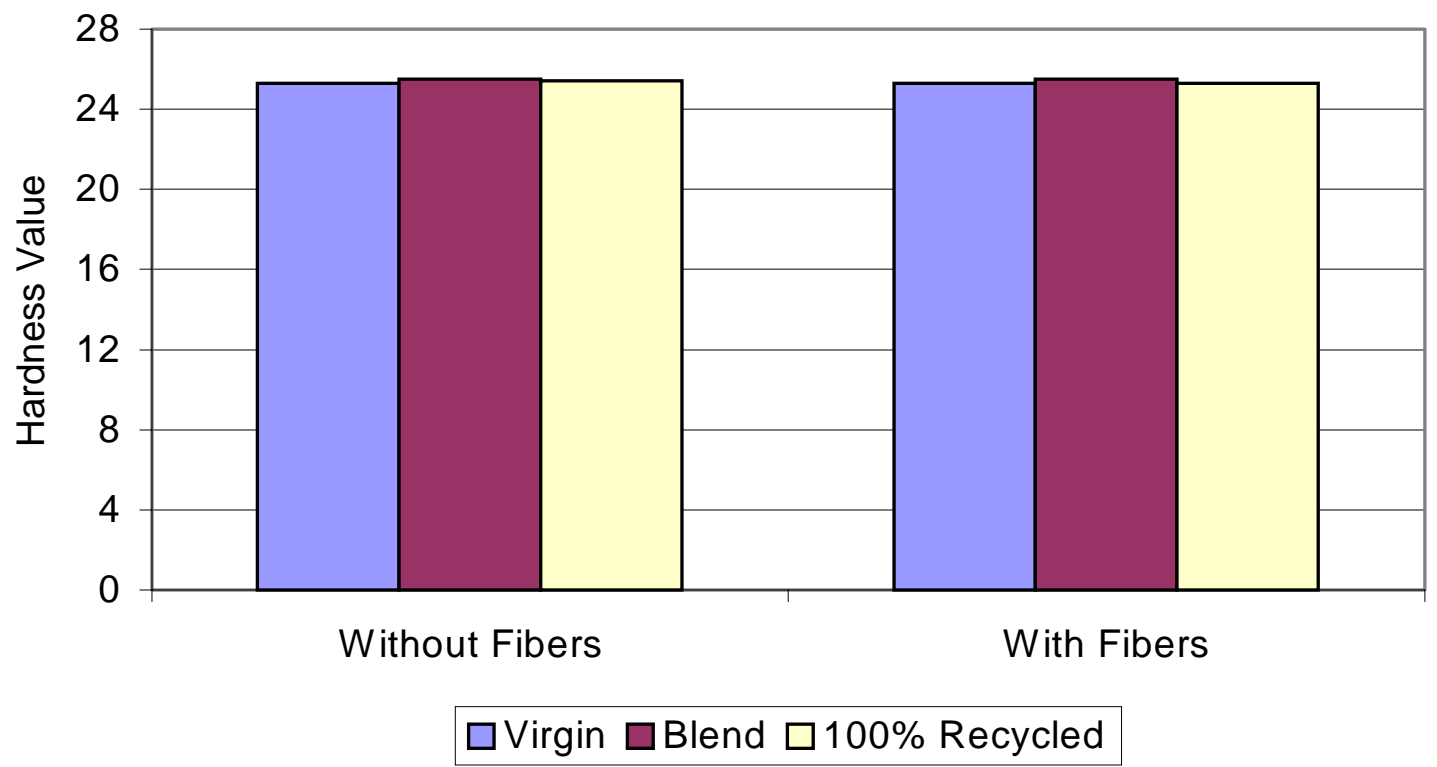

Fig. 4.31 Comparison of Hardness Values of PC with 626g Weight (12\% Fiber Volume Fraction) 
Table 4.20 Analysis and Comparison of Hardness Test Results on PC (\% Increase/Decrease)

\begin{tabular}{|c|l|l|c|c|}
\hline Effect of & \multicolumn{1}{|c|}{$\begin{array}{c}\text { Specimen } \\
\text { Type }\end{array}$} & $\begin{array}{c}\text { Compared } \\
\text { with }\end{array}$ & $\begin{array}{c}\text { Without } \\
\text { Weight }\end{array}$ & $\begin{array}{c}\text { With 626g } \\
\text { Weight }\end{array}$ \\
\hline & & & \% & \% \\
\hline \multirow{2}{*}{$\begin{array}{c}\text { Recycling } \\
\text { (Without Fibers) }\end{array}$} & HP3 (R) & \multirow{2}{*}{ HP1 (V) } & 0.0 & +0.4 \\
\cline { 2 - 3 } & HP5 (B) & & +0.9 & +0.8 \\
\hline $\begin{array}{c}\text { Recycling } \\
\text { (With Fibers) }\end{array}$ & HP4 (R-F) & \multirow{2}{*}{ HP2 (V-F) } & 0.0 & 0.0 \\
\cline { 2 - 5 } & HP6 (B-F) & & 0.0 & +0.8 \\
\hline \multirow{2}{*}{ Fiber Addition } & HP2 (V-F) & HP1 (V) & +0.9 & 0.0 \\
\cline { 2 - 5 } & HP4 (R-F) & HP3 (R) & +0.9 & +0.4 \\
\cline { 2 - 5 } & HP6 (B-F) & HP5 (B) & 0.0 & 0.0 \\
\hline
\end{tabular}

Note: H-Hardness; P-PC; V-Virgin; R-100\% Recycled; B-Blend (80\% virgin and 20\% Recycled); F-Fiber; +ve sign -Increase; -ve sign- Reduction. For absolute values refer to Table 4.19.

- Compared to virgin polymers, hardness values of the $100 \%$ recycled polymers were unchanged whereas the blend increased by $0.9 \%$ using no weight, and increased by 0.8 and $0.4 \%$ respectively, using the $626 \mathrm{~g}$ weight.

- Compared to virgin polymers with fibers, hardness values of the blend and $100 \%$ recycled polymers with fibers were unchanged using no weight, and increased by 0.8 and remained unchanged respectively, using the $626 \mathrm{~g}$ weight.

- Addition of $12 \%$ fiber volume fraction of randomly oriented and chopped glass fibers to virgin, blend and $100 \%$ recycled polymers resulted in hardness values increasing $0.9 \%, 0.9 \%$ and remaining unchanged respectively, using no weight and remained unchanged, increased $0.4 \%$, and remained unchanged using the $626 \mathrm{~g}$ weight.

- Compared to the ABS polymer, the hardness values for the PC polymer with and without fibers was nearly identical. 


\subsection{Creep Test}

\subsubsection{Results, Analysis, and Discussion of Creep Tests on ABS}

Results of the creep study are briefly summarized in the following section. Creep coefficients in Table 4.21 and 4.22 refer to the ratio of creep strain to initial strain at the instant of load application with $50 \%$ and $20 \%$ sustained loading, respectively. The designations in the following tables and charts of A1, A3, and A5 refer to the virgin, $100 \%$ recycled, and blend ABS polymers without fibers respectively, whereas A2, A4, and A6 refer to the virgin, $100 \%$ recycled, and blend ABS polymers with fibers. At $50 \%$ of ultimate loading, ABS specimens with recycled polymer blend and $100 \%$ recycled polymer without fibers failed at 38 days. Both of these specimens were connected in series. At $20 \%$ of ultimate loading, the blend and $100 \%$ recycled polymer without fibers are at 0.860 and 1.179 , respectively at 130 days. The virgin polymer specimen without fibers at a stress level of $50 \%$, failed at 45 days. At $20 \%$ of loading, the virgin polymer specimen without fibers is 0.812 at 90 days. Creep testing on the specimens with fibers is currently being conducted at both $50 \%$ and $20 \%$ of the loading. It is to be noted that these specimens are performing well under these sustained loads. In practice, sustained stress on the fiber-reinforced polymers is limited to less than 20\%. In Figs 4.32 to 4.35 , the primary and secondary creep is clearly visible. Furthermore, if the specimens are tested at a greater duration, the tertiary creep should become recognizable. During the creep testing, it was concluded that the variation in temperature, sometimes as much as $10-15^{\circ} \mathrm{F}$, was responsible for the excessive rise and fall of the creep values at various times throughout the test. Further testing is necessary to determine the degree to which 
the creep values are effected by this temperature variation. Complete creep data is shown in Appendix-F.

Table 4.21 Creep Data of 145 Days for ABS Specimens with $\approx 50 \%$ Sustained Loading

\begin{tabular}{|c|c|c|c|c|c|c|}
\hline Specimen & \multicolumn{7}{|c|}{ Duration } \\
\hline & 3 Days & 7 Days & 16 Days & 45 Days & 90 Days & 145 Days \\
\hline A1 & 0.322 & 0.428 & 0.609 & 0.996 & - & - \\
\hline A2 & 0.083 & 0.116 & 0.152 & 0.259 & 0.335 & 0.472 \\
\hline A3 & 0.371 & 0.483 & 0.681 & - & - & - \\
\hline A4 & 0.161 & 0.201 & 0.269 & 0.436 & 0.595 & 0.861 \\
\hline A5 & 0.215 & 0.284 & 0.405 & - & - & - \\
\hline A6 & 0.140 & 0.173 & 0.230 & 0.365 & 0.497 & 0.710 \\
\hline
\end{tabular}

Table 4.22 Creep Data of 130 Days for ABS Specimens with $\approx 20 \%$ Sustained Loading

\begin{tabular}{|c|c|c|c|c|c|c|}
\hline Specimen & \multicolumn{7}{|c|}{ Duration } \\
\hline & 3 Days & 7 Days & 16 Days & 45 Days & 90 Days & 130 Days \\
\hline A1 & 0.096 & 0.126 & 0.214 & 0.381 & 0.812 & - \\
\hline A2 & 0.049 & 0.062 & 0.088 & 0.118 & 0.221 & - \\
\hline A3 & 0.043 & 0.083 & 0.160 & 0.350 & 0.541 & 0.860 \\
\hline A4 & 0.030 & 0.045 & 0.069 & 0.108 & 0.222 & - \\
\hline A5 & 0.100 & 0.152 & 0.260 & 0.512 & 0.762 & 1.179 \\
\hline A6 & 0.049 & 0.058 & 0.089 & 0.181 & 0.291 & - \\
\hline
\end{tabular}




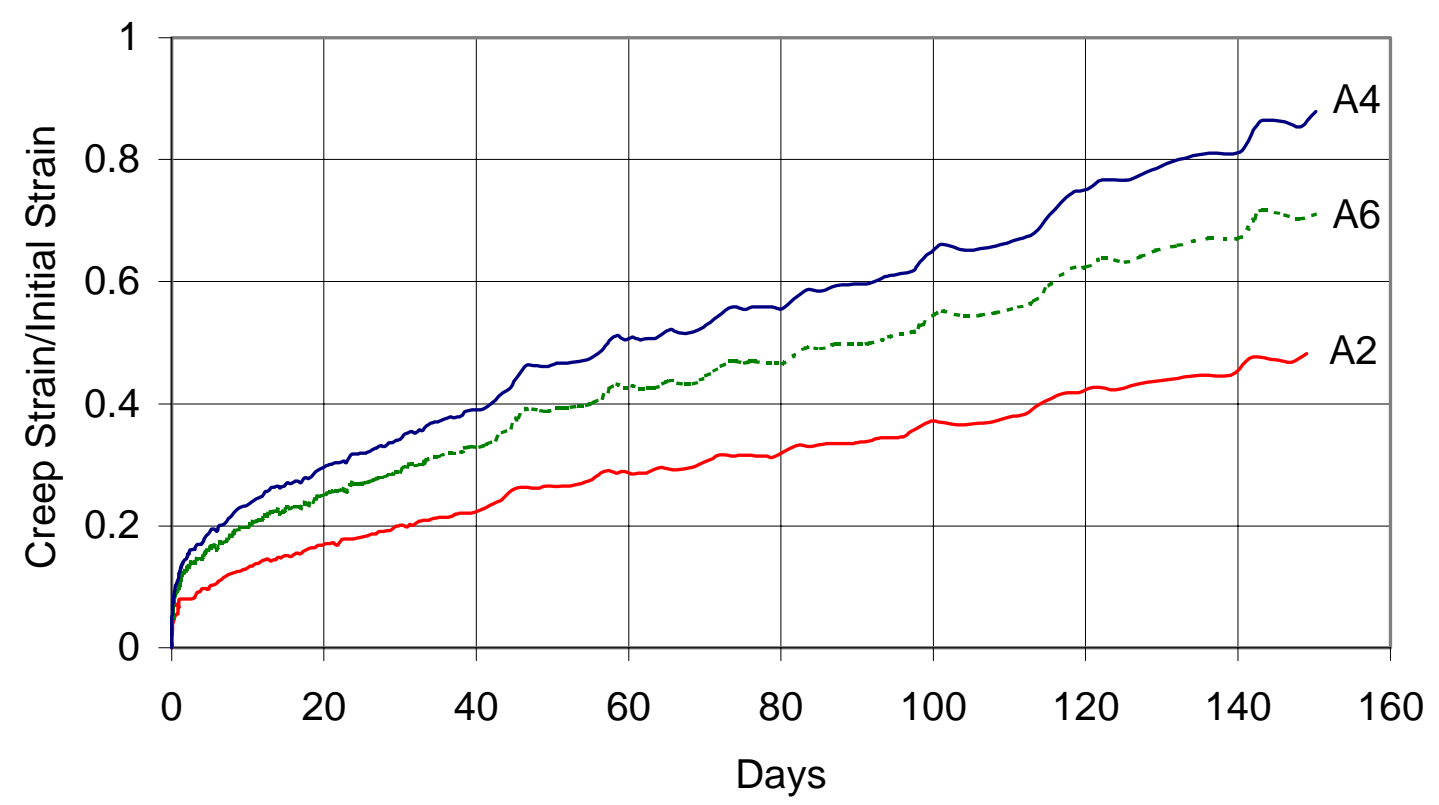

Fig. 4.32 Creep Curves for ABS with 12\% Fiber Volume Fraction ( $\approx 50 \%$ Ultimate Load)

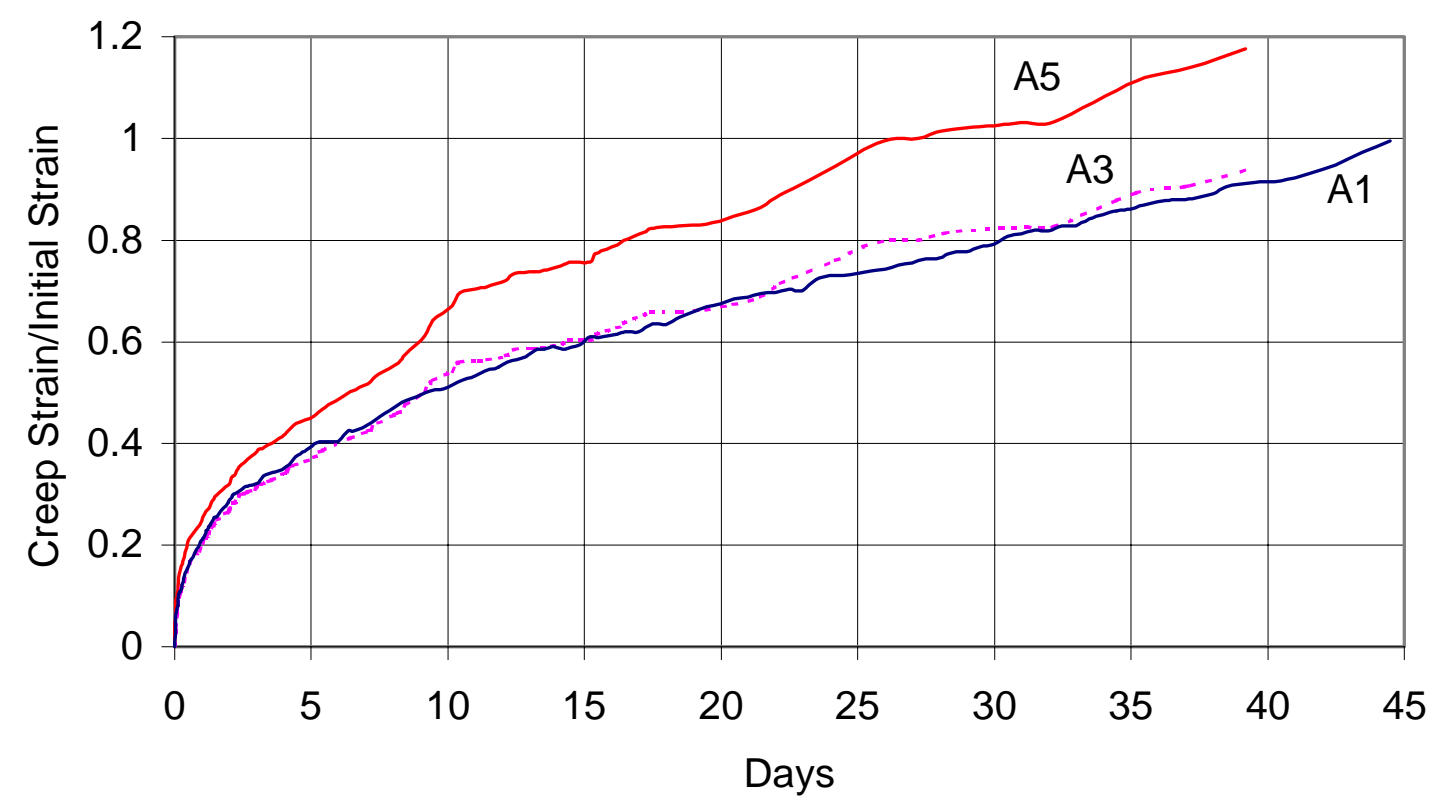

Fig. 4.33 Creep Curves for ABS without Fibers ( $\approx 50 \%$ Ultimate Load) 


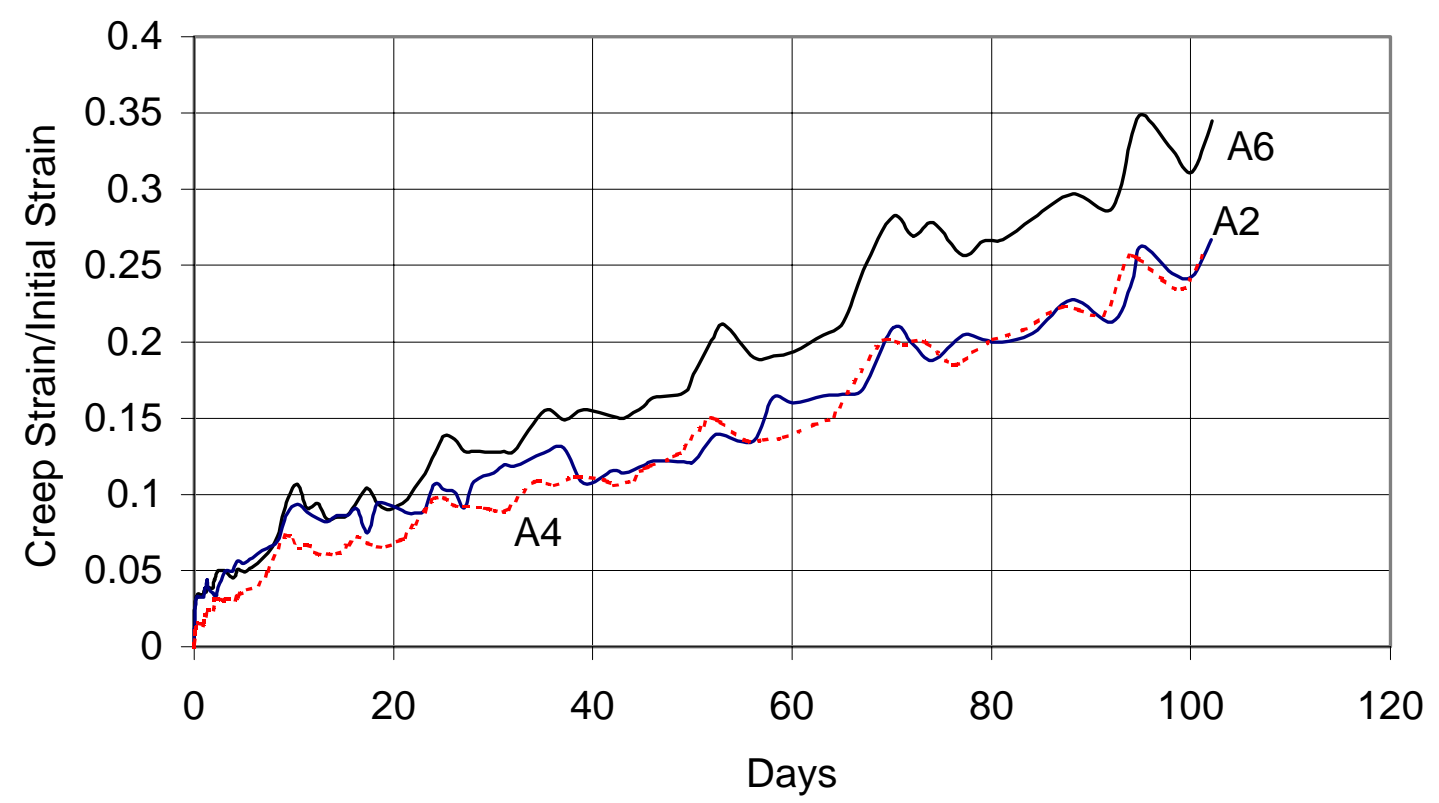

Fig. 4.34 Creep Curves for ABS with 12\% Fiber Volume Fraction ( $220 \%$ Ultimate Load)

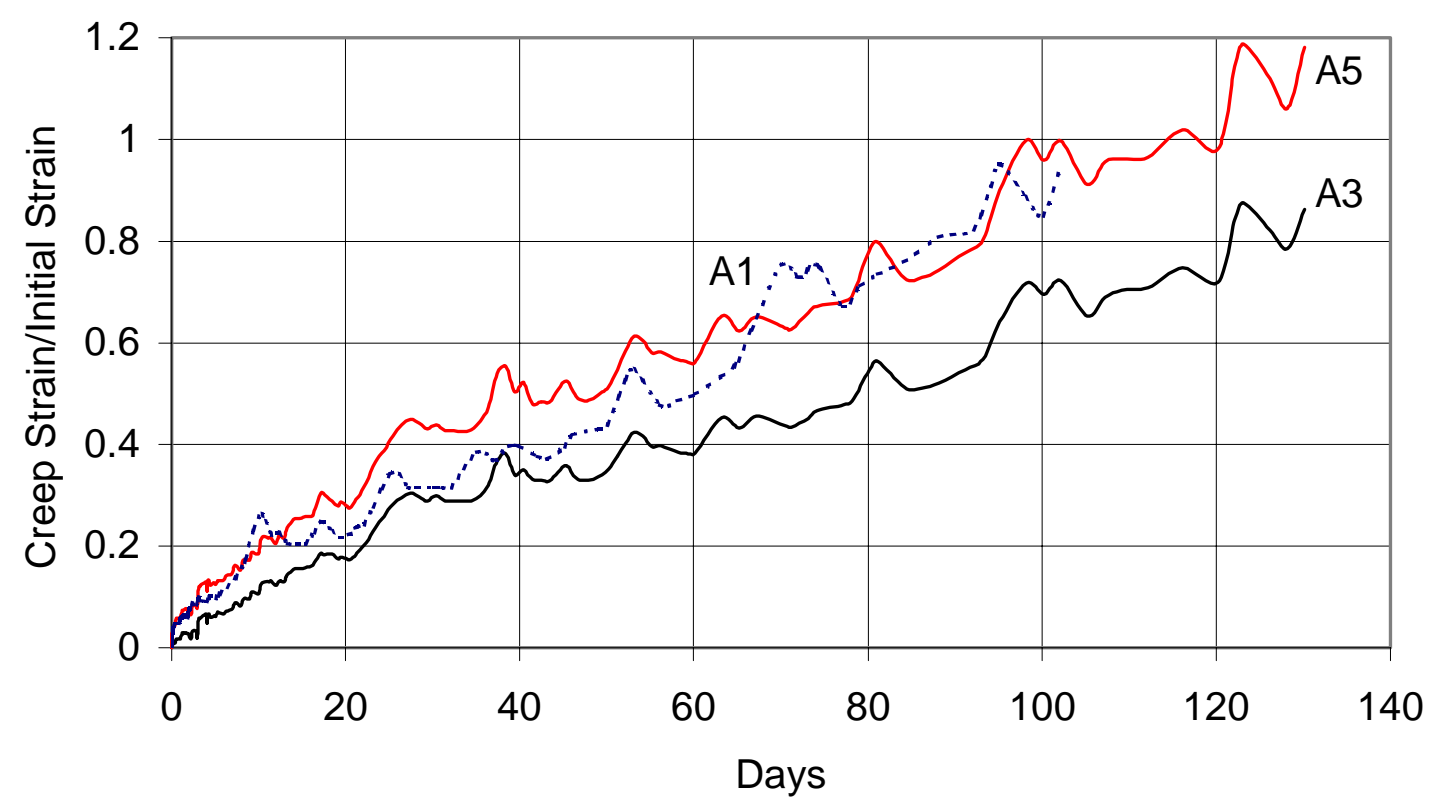

Fig. 4.35 Creep Curves for ABS without Fibers ( $\approx 20 \%$ Ultimate Load) 
- For ABS specimens without fibers at 16 days duration and $\approx 50 \%$ sustained load, the creep values are $0.609,0.681$, and 0.405 for the virgin, $100 \%$ recycled, and blend respectively. For 90 days duration and $\approx 20 \%$ sustained load, the creep values are $0.812,0.541$, and 0.762 for the virgin, $100 \%$ recycled, and blend respectively.

- For $\mathrm{ABS}$ specimens with fibers at 145 days duration and $\approx 50 \%$ sustained load, the creep values are $0.472,0.861$, and 0.710 for the virgin, $100 \%$ recycled, and blend respectively. For 90 days duration and $\approx 20 \%$ sustained load, the creep values are $0.221,0.222$, and 0.291 for the virgin, $100 \%$ recycled, and blend respectively.

- Polymers alone, i.e., without glass fibers, are not suitable for high-sustained load applications. Creep of polymers is limited by the use of fibers.

- Recycled polymers and their blends showed creep-life of about $40 \%$ of those of virgin polymers without fibers at a high-sustained load of $50 \%$. These results are based on single specimen tests and further tests need to be carried out with additional samples.

\subsubsection{Results, Analysis, and Discussion of Creep Tests on PC}

Results of the creep study are briefly summarized in the following section. Creep coefficients in Table 4.23 and 4.24 refer to the ratio of creep strain to initial strain at the instant of load application with $50 \%$ and $20 \%$ sustained loading, respectively. The designations in the following tables and charts of P1, P3, and P5 refer to the virgin, 100\% recycled, and blend PC polymers without fibers respectively, whereas P2, P4, and P6 refer to the virgin, $100 \%$ recycled, and blend PC polymers with fibers. Due to time constraints, the PC creep test was conducted for a period of 16 days. In Figs. 4.36 to 
4.39, the primary and secondary creep is clearly visible. Furthermore, if the specimens are tested at a greater duration, the tertiary creep should become recognizable. During the creep testing, it was concluded that the variation in temperature, sometimes as much as $10-15^{\circ} \mathrm{F}$, was responsible for the excessive rise and fall of the creep values at various times throughout the test. Further testing is necessary to determine the degree to which the creep values are effected by this temperature variation. Complete creep data is shown in Appendix-F.

Table 4.23 Creep Data of 16 Days for PC Specimens with $\approx 50 \%$ Sustained Loading

\begin{tabular}{|c|c|c|c|}
\hline Specimen & \multicolumn{3}{|c|}{ Duration } \\
\hline & 3 Days & 7 Days & 16 Days \\
\hline P1 & 0.429 & 0.499 & 0.612 \\
\hline P2 & 0.170 & 0.207 & 0.253 \\
\hline P3 & 0.396 & 0.455 & 0.539 \\
\hline P4 & 0.211 & 0.263 & 0.333 \\
\hline P5 & 0.390 & 0.469 & 0.610 \\
\hline P6 & 0.183 & 0.225 & 0.290 \\
\hline
\end{tabular}

Table 4.24 Creep Data of 16 Days for PC Specimens with $\approx 20 \%$ Sustained Loading

\begin{tabular}{|c|c|c|c|}
\hline Specimen & \multicolumn{3}{|c|}{ Duration } \\
\hline & 3 Days & 7 Days & 16 Days \\
\hline P1 & 0.291 & 0.386 & 0.471 \\
\hline P2 & 0.077 & 0.109 & 0.139 \\
\hline P3 & 0.308 & 0.426 & 0.537 \\
\hline P4 & 0.114 & 0.151 & 0.185 \\
\hline P5 & 0.191 & 0.263 & 0.329 \\
\hline P6 & 0.081 & 0.115 & 0.148 \\
\hline
\end{tabular}




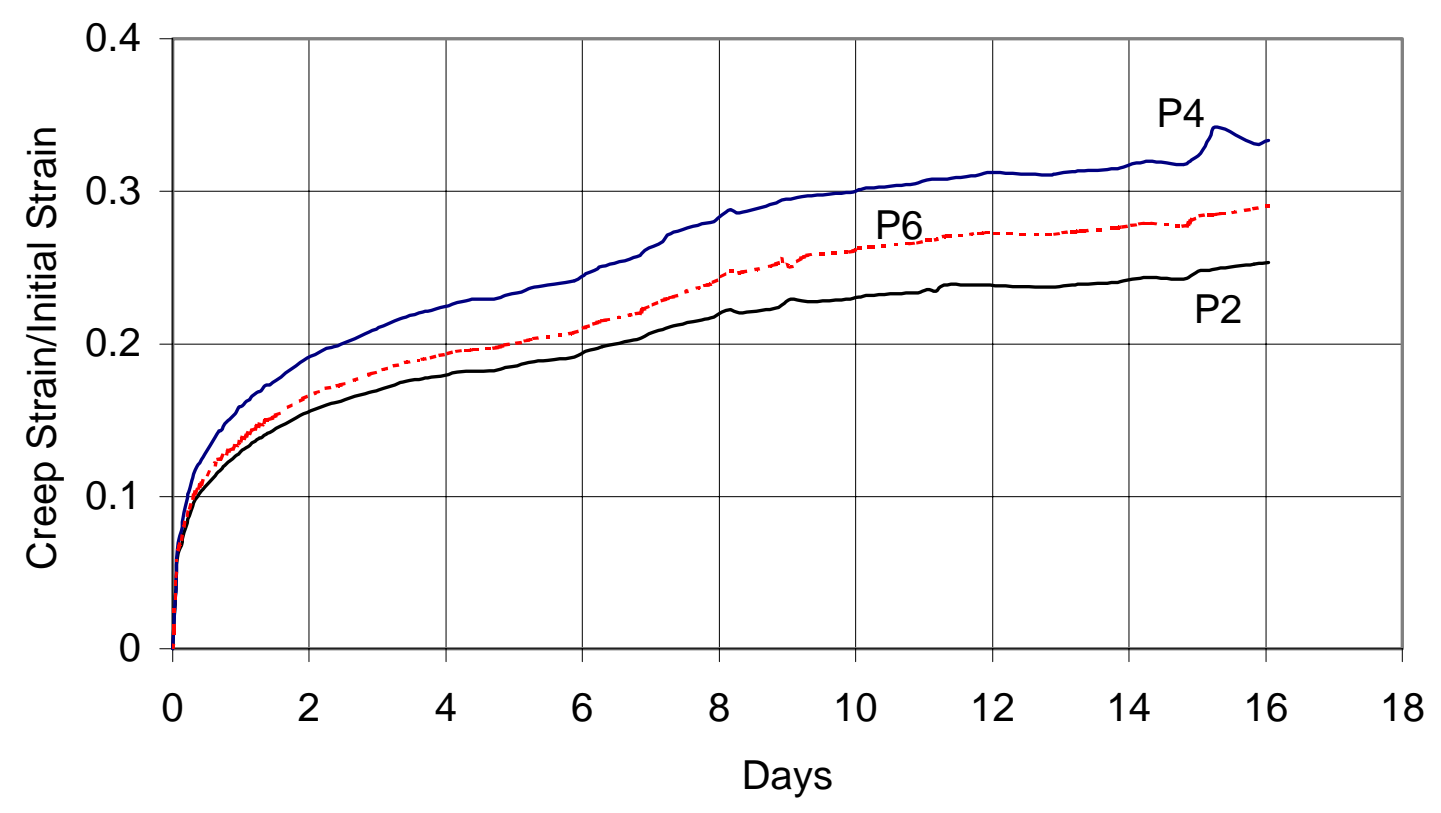

Fig. 4.36 Creep Curves for PC with 12\% Fiber Volume Fraction ( $\approx 50 \%$ Ultimate Load)

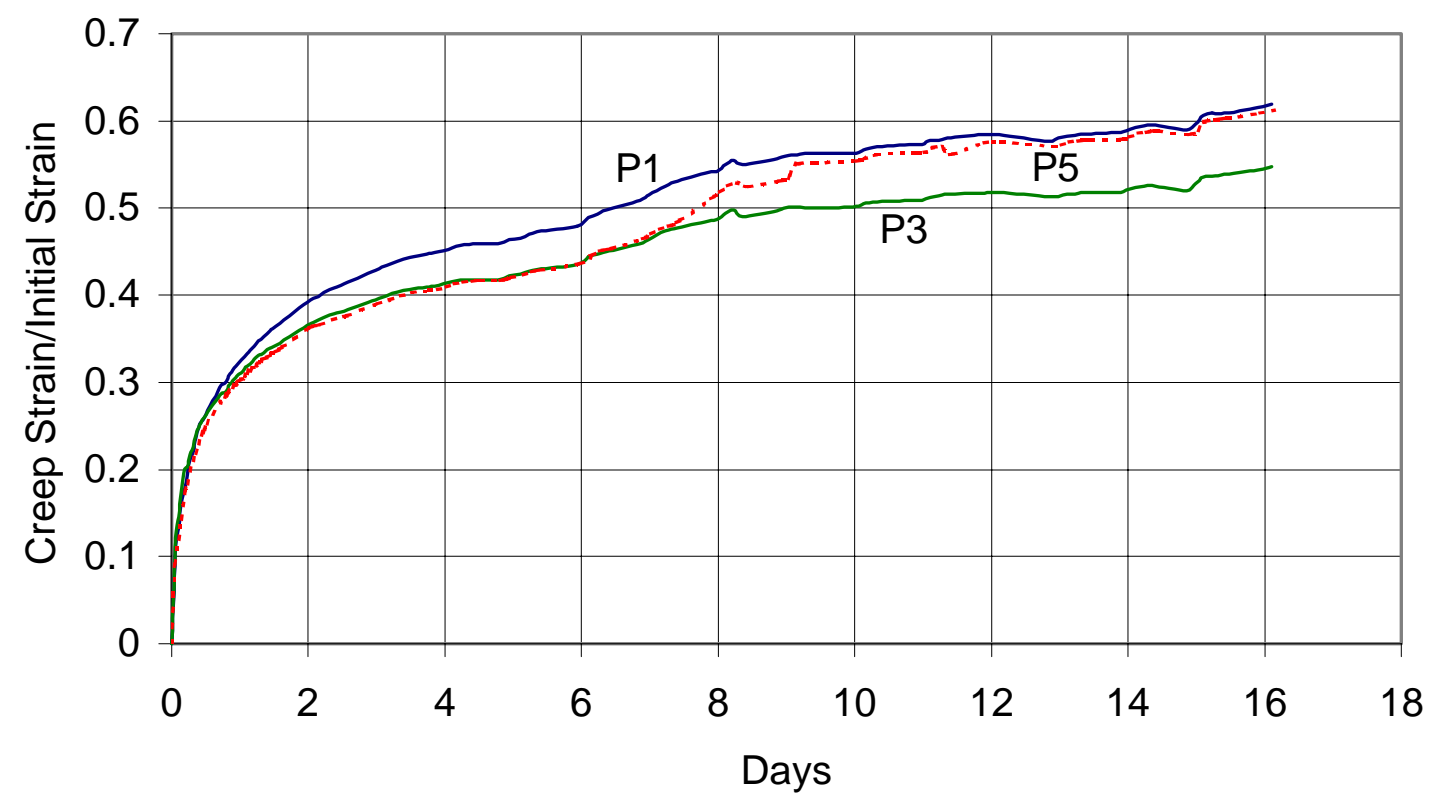

Fig. 4.37 Creep Curves for PC without Fibers ( $\approx 50 \%$ Ultimate Load) 


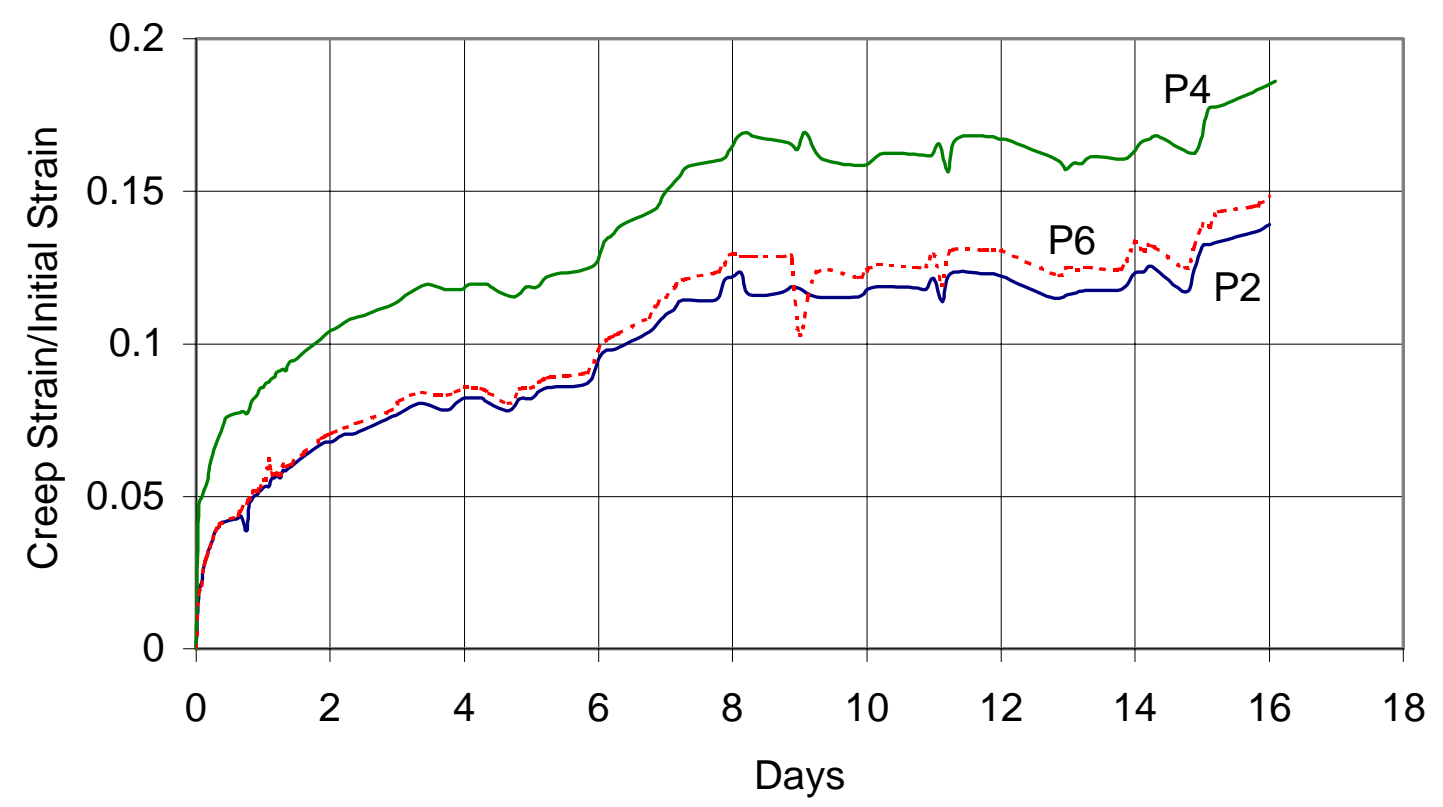

Fig. 4.38 Creep Curves for PC with 12\% Fiber Volume Fraction ( 20\% Ultimate Load)

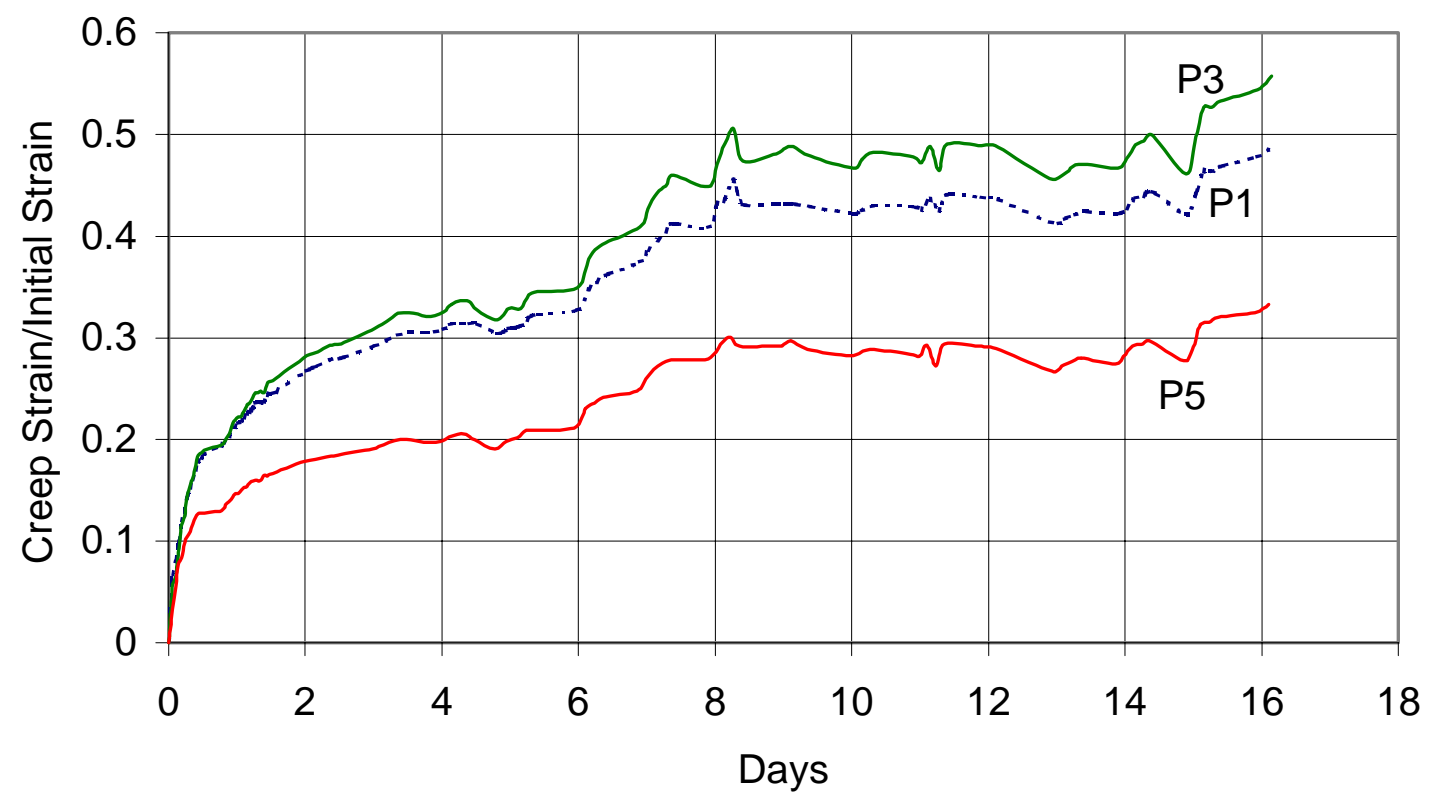

Fig. 4.39 Creep Curves for PC without Fibers ( $\approx 20 \%$ Ultimate Load) 
- For PC specimens without fibers at 16 days duration and $\approx 50 \%$ sustained load, the creep values are $0.612,0.539$, and 0.610 for the virgin, $100 \%$ recycled, and blend respectively. For 16 days duration and $\approx 20 \%$ sustained load, the creep values are $0.471,0.537$, and 0.329 for the virgin, $100 \%$ recycled, and blend respectively.

- For PC specimens with fibers at 16 days duration and $\approx 50 \%$ sustained load, the creep values are $0.253,0.333$, and 0.290 for the virgin, $100 \%$ recycled, and blend respectively. For 16 days duration and $\approx 20 \%$ sustained load, the creep values are $0.139,0.185$, and 0.148 for the virgin, $100 \%$ recycled, and blend respectively.

- Polymers alone, i.e., without glass fibers, are not suitable for high sustained load applications. Creep of polymers is limited by the use of fibers.

- For both $50 \%$ and $20 \%$ sustained loading, the ABS specimens exhibited lower creep values than those of the $\mathrm{PC}$ at a 16-day duration in all cases except for the P3 specimen at $50 \%$ ultimate loading. In this case the creep value of the ABS was 0.681 at 16 days whereas the PC was 0.539 .

- Further testing is necessary in order to determine if the PC specimens will continue to exhibit higher creep values than the ABS specimens for extended duration's. 


\section{CHAPTER 5}

\section{ANALYTICAL COMPARISONS AND EVALUATIONS}

\subsection{Theoretical Analysis and Comparisons of Tension Test Results}

The following is a comparison of the theoretical equation used in obtaining the tension moduli for both the ABS and PC specimens with fibers to that of experimentally obtained data. Determination of the random modulus of these specimens is shown in Table 5.1. Table 5.2 is a comparison of experimental data of glass fiber reinforced ABS and PC specimens, with those computed from theoretical analysis. The tensile stiffness model for short-fiber randomly oriented composites is used for theoretical predictions (Agarwal and Broutman, 1980). Randomly oriented short-fiber composites are essentially isotropic in a plane and are produced by injection or compression molding. Analysis of unidirectional fiber composites requires knowledge of the elastic properties of the isotropic layers within the unidirectional composite. Predicting the tensile properties of randomly oriented short-fiber composites is much more complex. The following empirical formula is used to predict the tension modulus of such a composite (Agarwal and Broutman, 1980):

$$
\mathrm{E}_{\text {random }}=(3 / 8) \mathrm{E}_{\mathrm{L}}+(5 / 8) \mathrm{E}_{\mathrm{T}}
$$

where $\mathrm{E}_{\mathrm{L}}$ is the longitudinal moduli and $\mathrm{E}_{\mathrm{T}}$ is the transverse moduli of a short-fiber composite and can be determined experimentally or calculated using the Halpin-Tsai equations. The following is an explanation along with sample calculations to find tension stiffness using equation 5.1. Calculate the tension modulus, $\mathrm{E}_{\mathrm{L}}$ using the following Halpin-Tsai equation for longitudinal moduli (Agarwal and Broutman, 1980): 


$$
E_{L}=E_{m}\left[\left(1+(2 L / d) \eta_{L} V_{f}\right) /\left(1-\eta_{L} V_{f}\right)\right]
$$

Where, $\mathrm{V}_{\mathrm{f}}$ is the fiber volume fraction, which is about $12 \%$ in our case

$$
\begin{aligned}
& 1=\text { fiber length, } 4 \mathrm{~mm} \text { for the ABS composite } \\
& d=\text { fiber diameter, } 0.014 m m \text { for the ABS composite } \\
& \eta_{L}=\left[\left(E_{f} / E_{m}\right)-1\right] /\left[\left(E_{f} / E_{m}\right)+(21 / d)\right] \quad \text { (Agarwal and Broutman, 1980) }
\end{aligned}
$$

Where, $E_{\mathrm{f}}$ is the fiber modulus and $\mathrm{E}_{\mathrm{m}}$ is the matrix modulus, which is $72.4 \mathrm{Gpa}$ $\left(10.5 \times 10^{6} \mathrm{psi}\right)$ and $2.21 \mathrm{Gpa}\left(0.321 \times 10^{6} \mathrm{psi}\right)$, respectively.

Thus,

$$
\eta_{L}=[(72.4 / 2.21)-1] /[(72.4 / 2.21)+(2 * 4 / 0.014)]=0.053
$$

and

$$
\mathrm{E}_{\mathrm{L}}=2.21[(1+(2 * 4 / 0.014) 0.053 * 0.12) /(1-0.053 * 0.12)]=9.80 \mathrm{Gpa}\left(1.42 \times 10^{6} \mathrm{psi}\right)
$$

Calculate the transverse modulus, $\mathrm{E}_{\mathrm{T}}$ using the following Halpin-Tsai equation for transverse moduli (Agarwal and Broutman, 1980):

$$
\mathrm{E}_{\mathrm{T}}=\mathrm{E}_{\mathrm{m}}\left[\left(1+2 \eta_{\mathrm{T}} \mathrm{V}_{\mathrm{f}}\right) /\left(1-\eta_{\mathrm{T}} \mathrm{V}_{\mathrm{f}}\right)\right]
$$

where

$$
\eta_{\mathrm{T}}=\left[\left(\mathrm{E}_{\mathrm{f}} / \mathrm{E}_{\mathrm{m}}\right)-1\right] /\left[\left(\mathrm{E}_{\mathrm{f}} / \mathrm{E}_{\mathrm{m}}\right)+2\right] \quad \text { (Agarwal and Broutman, 1980) }
$$

Therefore,

$$
\eta_{\mathrm{T}}=[(72.4 / 2.21)-1] /[(72.4 / 2.21)+2]=0.914
$$

and

$$
\mathrm{E}_{\mathrm{T}}=2.21[(1+2 * 0.914 * 0.12) /(1-0.914 * 0.12)]=2.98 \mathrm{Gpa}\left(0.43 \times 10^{6} \mathrm{psi}\right)
$$

Now the random modulus is calculated from equation 5.1 as follows,

$$
\mathrm{E}_{\text {random }}=(3 / 8) * 9.80+(5 / 8) * 2.98=5.53 \mathrm{Gpa}\left(0.802 \times 10^{6} \mathrm{psi}\right)
$$


Computation of the random modulus using properties of each type of resin and fibers is shown in Table 5.1. A value of $E_{f}$ is constant throughout the ABS and PC polymers and is $72.4 \mathrm{Gpa}$. Values for $\mathrm{E}_{\mathrm{m}}$ can be found in Appendix A for both ABS and $\mathrm{PC}$ resins. Values of $\mathrm{V}_{\mathrm{f}}$ are listed in Table 5.1. For the ABS polymers, glass fibers having a fiber length of $4.0 \mathrm{~mm}$ diameter of $14 \mu$ were used, whereas for the PC polymers, glass fibers having a length of $3.18 \mathrm{~mm}$ and diameter of $13 \mu$ were used. Comparisons of $E_{\text {random }}$ using the theoretical equation versus experimental results are shown in Table 5.2.

Table 5.1 Determination of Random Modulus, $\mathbf{E}_{\text {random }}$

\begin{tabular}{|c|c|c|c|c|c|}
\hline \multicolumn{2}{|c|}{ Specimen } & $\mathrm{V}_{\mathrm{f}}$ & $\mathrm{E}_{\mathrm{L}}$ & $\mathrm{E}_{\mathrm{T}}$ & $\mathrm{E}_{\mathrm{random}}$ \\
\cline { 3 - 6 } & $\%$ & $\mathrm{GPa}\left(\mathrm{x} 10^{6} \mathrm{psi}\right)$ & $\mathrm{GPa}\left(\mathrm{x} 10^{6} \mathrm{psi}\right)$ & $\mathrm{GPa}\left(\mathrm{x} 10^{6} \mathrm{psi}\right)$ \\
\hline \multirow{2}{*}{$\begin{array}{c}\text { ABS with } \\
\text { Fibers }\end{array}$} & Virgin & 11.3 & $9.80(0.142)$ & $2.98(0.043)$ & $5.53(0.802)$ \\
\cline { 2 - 6 } & Blend & 12.3 & $10.76(0.156)$ & $3.41(0.049)$ & $6.19(0.898)$ \\
\cline { 2 - 6 } & $100 \%$ Rec. & 12.5 & $10.65(0.154)$ & $3.18(0.046)$ & $5.98(0.867)$ \\
\hline \multirow{2}{*}{$\begin{array}{c}\text { PC with } \\
\text { Fibers }\end{array}$} & Virgin & 12.1 & $10.10(0.146)$ & $2.88(0.042)$ & $5.59(0.811)$ \\
\cline { 2 - 6 } & Blend & 12.4 & $10.54(0.153)$ & $3.18(0.046)$ & $5.94(0.862)$ \\
\cline { 2 - 6 } & $100 \%$ Rec. & 11.4 & $9.60(0.139)$ & $2.73(0.040)$ & $5.31(0.770)$ \\
\hline
\end{tabular}

Table 5.2 Analysis and Comparison of $\mathbf{E}_{\text {random }}$ for Theoretical versus Experimental Results (\% Increase/Decrease)

\begin{tabular}{|c|c|c|c|c|}
\hline \multicolumn{2}{|c|}{ Specimen } & $\mathrm{E}_{\text {random }}($ Theoretical $)$ & $\mathrm{E}_{\text {random }}$ (Experimental) & Difference \\
\cline { 3 - 5 } & GPa $\left(\times 10^{6} \mathrm{psi}\right)$ & $\mathrm{GPa}\left(\mathrm{x} 10^{6} \mathrm{psi}\right)$ & $\%$ \\
\hline \multirow{2}{*}{$\begin{array}{c}\text { ABS with } \\
\text { Fibers }\end{array}$} & Virgin & $5.53(0.802)$ & $6.73(0.976)$ & 17.8 \\
\cline { 2 - 5 } & Blend & $6.19(0.898)$ & $6.49(0.941)$ & 4.6 \\
\cline { 2 - 5 } & $100 \%$ Rec. & $5.98(0.867)$ & $6.65(0.964)$ & 10.1 \\
\hline \multirow{2}{*}{$\begin{array}{c}\text { PC with } \\
\text { Fibers }\end{array}$} & Virgin & $5.59(0.811)$ & $7.09(1.029)$ & 21.1 \\
\cline { 2 - 5 } & Blend & $5.94(0.862)$ & $7.21(1.046)$ & 17.6 \\
\cline { 2 - 5 } & $100 \%$ Rec. & $5.31(0.770)$ & $6.85(0.993)$ & 22.5 \\
\hline
\end{tabular}

Experimental values of the tensile moduli in ABS and PC were found to be higher than theoretical values by as much as $22.5 \%$ as shown in Table 5.2. This difference is 
attributed to randomness of the fiber orientation that could have resulted in better fiber alignment in some specimens in comparison to other specimens or the presence of a more accurate equation than equation 5.1. This observation is based on the fact that variations in some specimens are as low as $4.6 \%$ and in others as high as $22.5 \%$. Though manufacturing methods and sizing were not the primary focus of this research, it appears that higher experimental values in PC specimens with fibers may be due to better processing, curing, and fiber compatibility (Table 5.2). Fiber content of the specimens shown in Table 5.1 were based on actual verification through Loss On Ignition (LOI) test, independently conducted with the help of Owens Corning Science and Technology Division (Schweizer, 2000).

\subsection{Theoretical Equations used in Bending Test Results}

The following are sample calculations for obtaining bending stress and stiffness values of $\mathrm{ABS}$ and $\mathrm{PC}$ specimens described in chapter 4 (Tables 4.5 and 4.7). The equation used to obtain the stiffness value is based on the deflection equation for threepoint bending. In order to calculate stress, the Euler bending equation was used. The sample calculation is shown for a virgin PC sample, BP1-8 (Appendix B7), without fibers. Equation 5.6 was used to determine the maximum bending stress,

$$
\sigma=\mathrm{Mc} / \mathrm{I}
$$

Where, $\mathrm{M}=$ the applied moment, PL/4 in our case

$\mathrm{c}=$ the perpendicular distance from the neutral axis to a point farthest away from the neutral axis, where $\sigma_{\max }$ acts.

$\mathrm{I}=$ the moment of inertia of the cross sectional area, $\mathrm{bh}^{3} / 12$ in our case

Therefore, 


$$
\sigma=((\mathrm{PL} / 4) * \mathrm{c}) /\left(\mathrm{bh}^{3} / 12\right)
$$

Where, $\mathrm{P}=$ maximum load taken by the specimen, $13.98 \mathrm{lbs}$ for our case

$$
\begin{aligned}
& \mathrm{L}=\text { span length, } 3.75^{\prime \prime} \\
& \mathrm{b}=\text { specimen base dimension, } 0.5^{\prime \prime} \\
& \mathrm{h}=\text { specimen height }, 0.125^{\prime \prime}
\end{aligned}
$$

Hence,

$$
\sigma=((13.98 * 3.75 / 4) *(.125 / 2)) /\left(\left(.5^{*} .125^{3}\right) / 12\right)=10065.60 \mathrm{psi}
$$

Equation 5.8 was rearranged, shown in equation 5.9, to determine the stiffness value,

$$
\delta=\mathrm{PL}^{3} / 48 \mathrm{EI}
$$

Where, $\delta=$ deflection at maximum load

$$
\begin{aligned}
& \mathrm{P}=\text { maximum load } \\
& \mathrm{L}=\text { span length } \\
& \mathrm{E}=\text { stiffness value } \\
& \mathrm{I}=\text { moment of inertia of the cross sectional area, } \mathrm{bh}^{3} / 12 \text { in our case }
\end{aligned}
$$

Rearranging equation 5.8 to solve for the stiffness value,

$$
\mathrm{E}=(\mathrm{P} / \delta) *\left(\mathrm{~L}^{3} / 48 \mathrm{I}\right)
$$

the quantity $(\mathrm{P} / \delta)$ is obtained from the slope of the linear regression line on the $\mathrm{P}-\delta$ curve as shown in Figure 5.1. Therefore,

$$
\mathrm{E}=(22.336) *\left(3.75^{3} / 48 *\left(.5^{*} .125^{3} / 12\right)\right)=0.302 \times 10^{6} \mathrm{psi}
$$




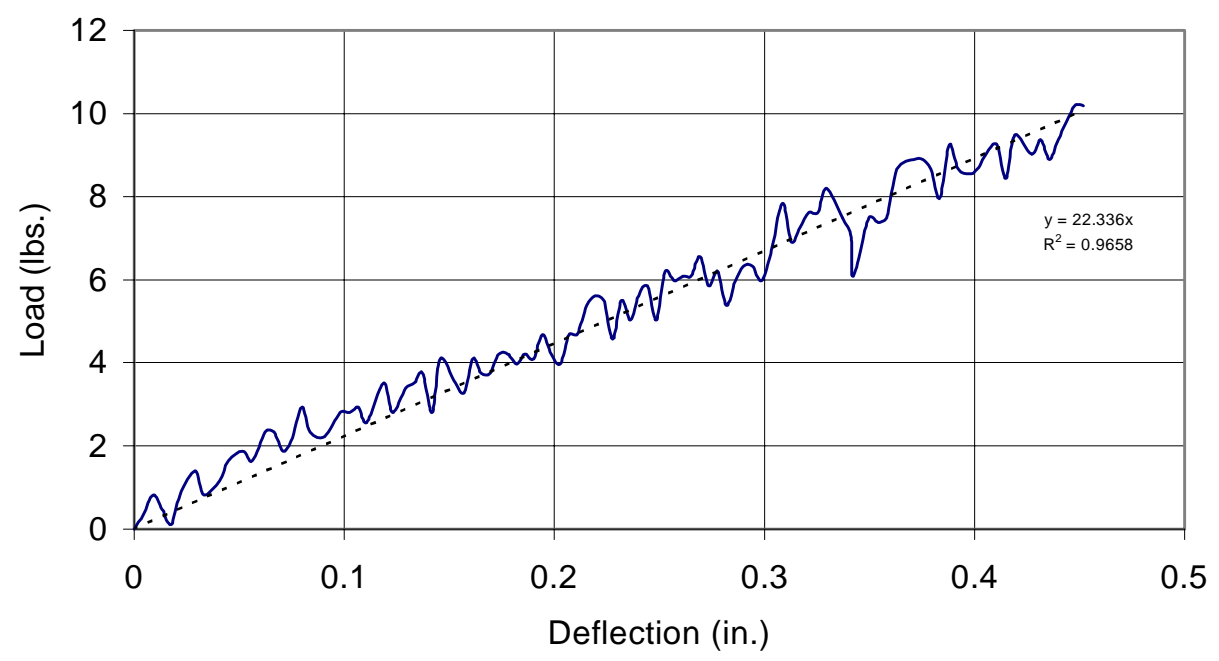

Fig. 5.1 Typical P- $\delta$ Plot with Linear Regression

\subsection{Theoretical Analysis of Compression Testing}

It is stated that no formulas are available for predicting compressive, inplane shear, and interlaminar shear strengths of random composites (Barbero, 1999). Several of the available models on aligned short-fiber composites were used for predicting the moduli of random short-fiber composites. The result of these attempts was as much as $50 \%$ different than the experimental values and will not be reported in this paper. Hence, further study is necessary for establishing a theoretical equation for the compressive modulus of random short-fiber composites.

\subsection{Theoretical Analysis of Impact and Hardness Testing}

No theoretical analysis was performed on the impact or hardness test specimens. The Izod impact test was conducted on a machine that had previously been calibrated to the specific height and kinetic energy required for this type of specimen. The values were obtained directly from the machines dial gage reading and then corrected using a 
chart provided by Instron for that particular machine (Fig 3.9). The hardness values were also obtained directly from the hardness-testing machine through a digital display located on the machine (Fig 3.13). With both the impact and hardness test, the readings have previously been calibrated through the manufacturer and are assumed correct.

\subsection{Conclusions}

- Experimental tensile moduli of PC and ABS specimens with fibers were as much as $22.5 \%$ greater than those obtained using theoretical equations.

- The bending moduli of both the ABS and PC specimens were found to be slightly higher than the tensile modulus.

- Currently no theoretical equation is available for the prediction of compressive modulus of random short-fiber composites (Barbero, 1999). 


\section{CHAPTER 6}

\section{SUMMARY, CONCLUSIONS AND RECOMMENDATIONS}

\subsection{Introduction}

Summary of tension, bending, compression, impact, hardness, and creep test results of virgin, blend, and $100 \%$ recycled $\mathrm{ABS}$ and $\mathrm{PC}$ specimens are provided in section 6.2 of this chapter. Conclusions and recommendations based on theoretical and experimental data are also included in section 6.3 and 6.4, respectively.

\subsection{Summary}

\subsubsection{Summary of Tension Test Results}

The following is a summary of typical values obtained through experimental tension tests for ABS specimens with and without fibers. Further explanation of these results can be found in section 4.2.1. Table 4.2 shows an analysis and comparison between the various specimens and the percent difference of each. A complete listing of each specimen's maximum load, maximum stress, and stiffness values is given in appendix A.

\section{ABS:}

- Typical maximum stress values for ABS specimens without fibers are on the order of 5500 to $6200 \mathrm{psi}$ with stiffness values ranging from $0.321 \times 10^{6}$ to $0.359 \times 10^{6}$ psi. For ABS specimens with fibers, typical maximum stress values vary between 8800 to 10300 psi with stiffness values ranging from $0.941 \times 10^{6}$ to $0.976 \times 10^{6} \mathrm{psi}$ 
- Compared to virgin polymers without fibers and with fibers, maximum stress reductions were under $15 \%$ for the blend and $100 \%$ recycled polymers. Similarly, stiffness variations were found to be within $12 \%$.

- Addition of $12 \%$ fiber volume fraction of chopped fibers to virgin, blend and $100 \%$ recycled polymers resulted in a tensile stress increase ranging between 50.6 and $68.8 \%$. Similarly, stiffness increase ranging between 162.1 to $204 \%$ was observed.

- Recycled polymers and blends were found to have slightly lower elongation than virgin polymers. However, both the materials showed elongations in excess of $8 \%$. Addition of fibers reduced the maximum strain values at failure to under $1.35 \%$

- Addition of unidirectional and continuous fibers is expected to provide higher strength and stiffness increase.

The following is a summary of typical values obtained through experimental tension tests for PC specimens with and without fibers. Further explanation of these results can be found in section 4.2.3. Table 4.4 shows an analysis and comparison between the various specimens and the percent difference of each. A complete listing of each specimen's maximum load, maximum stress, and stiffness values is given in appendix A.

\section{PC:}

- Typical maximum stress values for PC specimens without fibers are on the order of 8500 to 9000 psi with stiffness values ranging from $0.293 \times 10^{6}$ to $0.329 \times 10^{6}$ 
psi. For ABS specimens with fibers, typical maximum stress values vary between 15200 to $16600 \mathrm{psi}$ with stiffness values ranging from $0.993 \times 10^{6}$ to $1.046 \times 10^{6} \mathrm{psi}$.

- Compared to virgin polymers without fibers and with fibers, maximum stress reductions were under $8 \%$ for the blend and $100 \%$ recycled polymers. Similarly, stiffness variations were found to be within $10 \%$ for the first stiffness, E1, and within $15 \%$ for the second stiffness value, E2.

- Addition of $12 \%$ fiber volume fraction of chopped fibers to virgin, blend and $100 \%$ recycled polymers resulted in a tensile stress increase ranging between 77.6 and $90.2 \%$. Similarly, with the addition of $12 \%$ fiber volume fraction, stiffness increase ranging between 217.9 to $243 \%$ was observed for the first stiffness value, E1, and between 189.9 and $200 \%$ for the second stiffness value, E2.

- Recycled polymers and blends were found to have slightly lower elongation than virgin polymers due to impurities in the material. However, both the materials showed elongations in excess of $8 \%$. Addition of fibers reduced the maximum strain values at failure to under $3.14 \%$.

- Virgin polymers without fibers showed elongation in excess of $10 \%$. Extensometer available with the Instron machine had a maximum capacity of $10 \%$ and hence the readings were discontinued. Strain values of recycled and blend specimens were less than the virgin polymers. It is noted that the PC polymer with fibers exhibited higher ductility than the ABS polymer with fibers. Addition of fibers in the PC polymer yielded maximum strain at failure values in virgin, blend and $100 \%$ recycled polymers of $3.23,3.26$ and $2.96 \%$, respectively. 
For the ABS polymer with fibers, the maximum strain values at failure in virgin, blend and $100 \%$ recycled polymers was $1.51,1.18$ and $1.12 \%$, respectively.

- As with ABS, addition of unidirectional and continuous fibers is expected to provide higher strength and stiffness increase for PC.

\subsubsection{Summary of Bending Test Results}

The following is a summary of typical values obtained through experimental bending tests for ABS specimens with and without fibers. Further explanation of these results can be found in section 4.3.1. Table 4.6 shows an analysis and comparison between the various specimens and the percent difference of each. A complete listing of each specimen's maximum load, maximum stress, and stiffness values is given in appendix B.

\section{ABS:}

- Typical maximum stress values for ABS specimens without fibers vary between 9000 to 9600 psi with stiffness values of $0.40 \times 10^{6}$ psi. For ABS specimens with fibers, typical maximum stress values are on the order of 16500 to 17800 psi with stiffness values ranging from $1.02 \times 10^{6}$ to $1.11 \times 10^{6}$ psi.

- Compared to virgin polymers without fibers and with fibers maximum bending stress reductions or increases were within $7.1 \%$ for the blends and $100 \%$ recycled polymers. Stiffness increase in the blend and $100 \%$ recycled polymer were found to be within $8.8 \%$.

- Addition of $12 \%$ fiber volume fraction of chopped fibers to virgin, blend and $100 \%$ recycled polymers resulted in a bending stress increase ranging between 
72.7 and $95.7 \%$. Similarly, stiffness increase ranging between 155.0 to $177.5 \%$ was observed with the addition of $12 \%$ fiber volume fraction.

- Bending strength and stiffness values were found to be higher than the corresponding tensile values for all three types of polymers considered in this study.

The following is a summary of typical values obtained through experimental bending tests for PC specimens with and without fibers. Further explanation of these results can be found in section 4.3.3. Table 4.8 shows an analysis and comparison between the various specimens and the percent difference of each. A complete listing of each specimen's maximum load, maximum stress, and stiffness values is given in appendix B.

PC:

- Typical maximum stress values for PC specimens without fibers vary between 10200 to 11200 psi with stiffness values ranging from $0.291 \times 10^{6}$ to $0.332 \times 10^{6} \mathrm{psi}$. For ABS specimens with fibers, typical maximum stress values are on the order of 23200 to 24900 psi with stiffness values ranging from $0.916 \times 10^{6}$ to $0.993 \times 10^{6}$ psi.

- Compared to virgin polymers without fibers and with fibers maximum bending stress reductions or increases were within $9 \%$ for the blends and $100 \%$ recycled polymers. Stiffness increase in the blend and $100 \%$ recycled polymer were found to be within $12.3 \%$.

- Addition of $12 \%$ fiber volume fraction of chopped fibers to virgin, blend and $100 \%$ recycled polymers resulted in a bending stress increase ranging between 
122.8 and $139.8 \%$. Similarly, stiffness increase ranging between 191.3 to $214.8 \%$ was observed with the addition of $12 \%$ fiber volume fraction.

- Compared to the ABS polymer without fibers, the virgin, blend and $100 \%$ recycled PC polymer without fibers exhibited 11.3, 14.4, and 11.4\% higher maximum stress readings with $23.0,14.8$, and $22.2 \%$ more deflection at maximum stress, respectively.

- Compared to the ABS polymer with fibers, the virgin, blend and $100 \%$ recycled PC polymer with fibers exhibited 27.7, 33.7, and 27.8\% higher maximum stress readings with $44.4,31.9$, and $27.3 \%$ more deflection at maximum stress, respectively.

- Similar to ABS, PC bending strength and stiffness values were found to be higher than the corresponding tensile values for all three types of polymers considered in this study.

\subsubsection{Summary of Compression Test Results}

The following is a summary of typical values obtained through experimental compression tests for ABS specimens with and without fibers. Further explanation of these results can be found in section 4.4.1. Table 4.10 shows an analysis and comparison between the various specimens and the percent difference of each. A complete listing of each specimen's maximum load, maximum stress, and stiffness values is given in appendix C.

ABS:

- Typical maximum stress values for ABS specimens without vary between 8800 to 9000 psi with stiffness values ranging from $0.34 \times 10^{6}$ to $0.41 \times 10^{6} \mathrm{psi}$. For ABS 
specimens with fibers, typical maximum stress values are on the order of 13100 to 14900 psi with stiffness values ranging from $0.91 \times 10^{6}$ to $1.02 \times 10^{6} \mathrm{psi}$.

- Compared to virgin polymers without fibers and with fibers, maximum compressive stress increase up to $13.4 \%$ was observed for the blend and $100 \%$ recycled polymers. Stiffness increase up to $23.5 \%$ was also observed.

- Addition of $12 \%$ fiber volume fraction of chopped fibers to virgin, blend and $100 \%$ recycled polymers resulted in a compressive stress increase ranging between 46.5 and $66 \%$. Similarly, stiffness increase ranging between 167.6 to $343.5 \%$ was observed with the addition of $12 \%$ fiber volume fraction.

- Virgin polymers without fibers showed significant compressive strains in excess of $10 \%$. Strain values of recycled and blend specimens were less than the virgin polymers.

The following is a summary of typical values obtained through experimental compression tests for PC specimens with and without fibers. Further explanation of these results can be found in section 4.4.3. Table 4.12 shows an analysis and comparison between the various specimens and the percent difference of each. A complete listing of each specimen's maximum load, maximum stress, and stiffness values is given in appendix $\mathrm{C}$.

PC:

- Typical maximum stress values for ABS specimens without fibers vary between 10300 to 10550 psi with stiffness values ranging from $0.39 \times 10^{6}$ to $0.41 \times 10^{6}$ psi. For ABS specimens with fibers, typical maximum stress values are on the order of 20300 to 21200 psi with stiffness values ranging from $0.80 \times 10^{6}$ to $0.84 \times 10^{6}$ psi. 
- Compared to virgin polymers without fibers and with fibers, maximum compressive stress increase up to $3.9 \%$ was observed for the blend and $100 \%$ recycled polymers. Stiffness increase up to $5.0 \%$ was also observed.

- Addition of $12 \%$ fiber volume fraction of chopped fibers to virgin, blend and $100 \%$ recycled polymers resulted in a compressive stress increase ranging between 95.1 and $101.2 \%$. Similarly, stiffness increase ranging between 95.1 to $115.4 \%$ was observed with the addition of $12 \%$ fiber volume fraction.

- Compared to the ABS polymer without fibers, the virgin, blend and $100 \%$ recycled PC polymer without fibers exhibited 14.0, 14.7, and 14.7\% higher maximum stress readings with similar deflections at maximum stress, respectively.

- Compared to the ABS polymer with fibers, the virgin, blend and $100 \%$ recycled PC polymer with fibers exhibited $35.4,34.1$, and $28.2 \%$ higher maximum stress readings with similar deflections at maximum stress, respectively.

- As with ABS, virgin PC polymers without fibers showed significant compressive strains in excess of $10 \%$. Strain values of recycled and blend specimens were less than the virgin polymers.

\subsubsection{Summary of Impact Test Results}

The following is a summary of typical values obtained through experimental impact tests for ABS specimens with and without fibers. Further explanation of these results can be found in section 4.5.1. Table 4.14 shows an analysis and comparison between the various specimens and the percent difference of each. A complete listing of each specimen's impact strength and failure type is given in appendix D. 


\begin{abstract}
ABS:
- Typical impact strength values for ABS specimens without vary between 0.96 to 1.58. For ABS specimens with fibers, typical impact strength values are on the order of 2.17 to 3.50 .
\end{abstract}

- Compared to virgin polymers with or without fibers, impact strength of the blend and $100 \%$ recycled polymers decreased by a maximum of $39.2 \%$.

- Addition of $12 \%$ fiber volume fraction of randomly oriented and chopped glass fibers to virgin, blend and $100 \%$ recycled polymers resulted in maximum impact strength reduction of $59.7 \%$.

The following is a summary of typical values obtained through experimental impact tests for PC specimens with and without fibers. Further explanation of these results can be found in section 4.5.2. Table 4.16 shows an analysis and comparison between the various specimens and the percent difference of each. A complete listing of each specimen's impact strength and failure type is given in appendix D.

\title{
PC:
}

- Typical impact strength values for PC specimens without vary between 1.81 to 3.01. For ABS specimens with fibers, typical impact strength values are on the order of 13.53 to 14.80 .

- Compared to virgin polymers with or without fibers, impact strength of the blend and $100 \%$ recycled polymers decreased by a maximum of $39.9 \%$. 
- Addition of $12 \%$ fiber volume fraction of randomly oriented and chopped glass fibers to virgin, blend and $100 \%$ recycled polymers resulted in maximum impact strength reduction of $86.6 \%$.

- Compared to the ABS polymer without fibers, the virgin, blend and $100 \%$ recycled PC polymer without fibers exhibited 75.3, 84.0, and 83.9\% higher impact readings, respectively.

- Compared to the ABS polymer with fibers, the virgin, blend and $100 \%$ recycled PC polymer with fibers exhibited $47.5,55.1$, and $47.0 \%$ higher impact readings, respectively.

\subsubsection{Summary of Hardness Test Results}

The following is a summary of typical values obtained through experimental hardness tests for ABS specimens with and without fibers. Further explanation of these results can be found in section 4.6.1. Table 4.18 shows an analysis and comparison between the various specimens and the percent difference of each. A complete listing of each specimen's hardness values, with and without the $626 \mathrm{~g}$ weight, is given in appendix E.
ABS:
- Typical hardness values for ABS specimens without fibers vary between 10.9 to 11.2 without weight and 25.6 to 25.9 with $626 \mathrm{~g}$ weight. For ABS specimens with fibers, typical hardness values are on the order of 11.2 to 11.3 without weight and 25.7 to 25.8 with $626 \mathrm{~g}$ weight. 
- Compared to virgin polymers with or without fibers, hardness values of the blend and $100 \%$ recycled polymers were within $2.8 \%$ using no weight, and within $0.8 \%$ using a $626 \mathrm{~g}$ weight.

- Addition of $12 \%$ fiber volume fraction of randomly oriented and chopped glass fibers to virgin, blend and $100 \%$ recycled polymers resulted in maximum hardness value increase of $3.7 \%$ using no weight, and $0.4 \%$ using a $626 \mathrm{~g}$ weight.

The following is a summary of typical values obtained through experimental hardness tests for PC specimens with and without fibers. Further explanation of these results can be found in section 4.6.2. Table 4.20 shows an analysis and comparison between the various specimens and the percent difference of each. A complete listing of each specimen's hardness values, with and without the $626 \mathrm{~g}$ weight, is given in appendix E.

\section{PC:}

- Typical hardness values for PC specimens without fibers vary between 10.6 to 10.7 without weight and 25.3 to 25.5 with $626 \mathrm{~g}$ weight. For ABS specimens with fibers, typical hardness values are on the order of 10.7 without weight and 25.3 to 25.5 with $626 \mathrm{~g}$ weight.

- Compared to virgin polymers with or without fibers, hardness values of the blend and $100 \%$ recycled polymers were within $0.9 \%$ using no weight, and within $0.8 \%$ using a $626 \mathrm{~g}$ weight.

- Addition of $12 \%$ fiber volume fraction of randomly oriented and chopped glass fibers to virgin, blend and $100 \%$ recycled polymers resulted in maximum hardness value increase of $0.9 \%$ using no weight, and $0.4 \%$ using a $626 \mathrm{~g}$ weight. 
- Compared to the ABS polymer, the hardness values for the PC polymer with and without fibers was nearly identical.

\subsubsection{Summary of Creep Test Results}

The following is a summary of the creep test data of ABS specimens under sustained loads of $50 \%$ and $20 \%$ of the maximum. Tables 4.21 and 4.22 show creep coefficients for various intervals throughout the test. Further explanation of the creep data can be found in section 4.7.1. A complete listing creep data is shown in Appendix$\mathrm{F}$, in terms of microstrains.

\section{ABS:}

- For ABS specimens without fibers at 16 days duration and $\approx 50 \%$ sustained load, the creep values are $0.609,0.681$, and 0.405 for the virgin, $100 \%$ recycled, and blend respectively. For 90 days duration and $\approx 20 \%$ sustained load, the creep values are $0.812,0.541$, and 0.762 for the virgin, $100 \%$ recycled, and blend respectively.

- For ABS specimens with fibers at 145 days duration and $\approx 50 \%$ sustained load, the creep values are $0.472,0.861$, and 0.710 for the virgin, $100 \%$ recycled, and blend respectively. For 90 days duration and $\approx 20 \%$ sustained load, the creep values are $0.221,0.222$, and 0.291 for the virgin, $100 \%$ recycled, and blend respectively.

- Recycled polymers and their blends showed creep-life of about $40 \%$ of those of virgin polymers without fibers at a high-sustained load of $50 \%$. These results are based on single specimen tests and further tests need to be carried out with additional samples. 
- For sustained load applications, fibers have to be used to reduce creep strain rate and enhance rupture of the specimen.

- Virgin polymers have a better creep-life compared to recycled polymers and their blends due to fewer impurities in the specimens.

- Recycled polymers and their blends showed creep-life of about $40 \%$ of those of virgin polymers without fibers at a high-sustained load of $50 \%$. These results are based on single specimen tests and further tests need to be carried out with additional samples.

The following is a summary of the creep test data of PC specimens under sustained loads of $50 \%$ and $20 \%$ of the maximum. Tables 4.23 and 4.24 show creep coefficients for various intervals throughout the test. Further explanation of the creep data can be found in section 4.7.2. A complete listing creep data is shown in Appendix$\mathrm{F}$, in terms of microstrains.

\section{PC:}

- For PC specimens without fibers at 16 days duration and $\approx 50 \%$ sustained load, the creep values are $0.612,0.539$, and 0.610 for the virgin, $100 \%$ recycled, and blend respectively. For 16 days duration and $\approx 20 \%$ sustained load, the creep values are $0.471,0.537$, and 0.329 for the virgin, $100 \%$ recycled, and blend respectively.

- For PC specimens with fibers at 16 days duration and $\approx 50 \%$ sustained load, the creep values are $0.253,0.333$, and 0.290 for the virgin, $100 \%$ recycled, and blend respectively. For 16 days duration and $\approx 20 \%$ sustained load, the creep values are $0.139,0.185$, and 0.148 for the virgin, $100 \%$ recycled, and blend respectively. 
- For both $50 \%$ and $20 \%$ sustained loading, the ABS specimens exhibited lower creep values than those of the PC at a 16 day duration in all cases except for the P3 specimen at 50\% ultimate loading. In this case the creep value of the ABS was 0.681 at 16 days whereas the PC was 0.539 .

- Further testing is necessary in order to determine if the PC specimens will continue to exhibit higher creep values than the ABS specimens for extended duration's.

- The higher creep values for PC compared to ABS at the 16 day interval is most likely attributed to the temperature at the time of measurement. The 16 day interval for the ABS polymer was during the winter months (average temperature of $32^{\circ} \mathrm{F}$ ), whereas the PC polymer's 16 day interval was during the summer months (average temperature of $75^{\circ} \mathrm{F}$ ). Because the testing facility is unable to control the temperature fluctuation within the building, the higher temperature had more effect on the PC polymer and thus allowed it to creep more than that of the ABS polymer.

- Polymers alone, i.e., without glass fibers, are not suitable for high-sustained load applications. Fibers are essential to control creep of polymers for sustained load applications.

\subsection{Conclusions}

Results of this study indicate the potential of using recycled polymers for infrastructure and automotive applications. Use of $100 \%$ recycled ABS polymers resulted in tensile, bending and compressive strength and stiffness reduction on an average of about $10 \%$ and a maximum of $15 \%$. Reduction in impact strength of the blend and 
recycled polymers was more than the reductions in tensile, bending and compressive stresses in ABS polymers. Compared to virgin ABS polymers with and without fibers, impact strength of the blended polymers with and without fibers was less by 24.1 and $31.8 \%$, respectively. Maximum impact strength reductions up to $39.2 \%$ were observed in $100 \%$ recycled ABS polymer. Hardness values of the blended and $100 \%$ recycled ABS polymers were within $2.8 \%$ when compared to virgin PC polymer with and without fibers. The use of fibers is essential to control the creep of different types of ABS virgin and recycled polymers for sustained load applications.

For PC polymers, use of $100 \%$ recycled polymers resulted in tensile, bending, and compressive strength and stiffness reduction within $13 \%$. Reduction in impact strength of the blended and recycled PC polymers was more than the reductions in tensile, bending and compressive stresses. Compared to virgin PC polymers with and without fibers, impact strengths of the blended polymers with and without fibers was less than $11.3 \%$ and $4.5 \%$, respectively. Maximum impact strength reductions up to $39.9 \%$ were observed in $100 \%$ recycled PC polymers. Hardness values of the blend and $100 \%$ recycled PC polymers were within $0.9 \%$ when compared to virgin PC polymer with and without fibers. Use of fibers is essential to control creep in virgin and recycled PC polymers, as in ABS, for sustained load applications.

Throughout the testing, virgin ABS and PC specimens with and without fibers consistently performed better than the blended and $100 \%$ recycled polymeric materials. Several factors contribute to lower mechanical properties in the blended and $100 \%$ recycled specimens. These factors effect the molecular structure of the material and include physical effects such as ultraviolet radiation and thermal differences. Other 
factors include chemical effects such as water absorption, which can lead to hydration and oxidation in PC materials and cross-linking in the ABS material. As the ABS and PC materials are recycled several times, i.e. 4 or 5 times, these factors will further degrade the material to a point where the mechanical properties are inadequate for usage in the infrastructure or automotive fields (Liang 2000).

Throughout the research, bending stresses were found to be higher than those in tension. There are many different failure modes that are identified in the literature to establish failure stress. Obviously the bending failure mode is more complex than tension because non-uniform stress distribution, shear stress, and secondary effects from axial stresses are induced under three-point bending loads. Therefore such theories as Tsai-Wu and Tsai-Hill may better fit and provide a better correlation between bending and tension than the failure theories corresponding to the principal stress theory.

During testing, the impact test results did not follow the same trend as found with tension, bending, compression, and hardness tests. The large differences in impact results of the blended and $100 \%$ recycled materials, when compared to the virgin material, are attributed to more impurities found within these materials. With the introduction of fibers into the blended and 100\% recycled materials, impact values are much lower than those without fibers because of stress concentrations effects caused by the fibers as well as impurities in recycled products. During a static test, such as tension, bending, compression, and hardness, the load is applied in a gradual manner, thus allowing the energy within the system to go around the impurities, whereas in dynamic tests, such as impact, kinetic energy is applied to the specimen at high velocities. The high velocity stress wave transmittal does not provide sufficient time for stresses to pass around the 
impurities, but develops high stresses near impurities through the propagating wave resulting in failure at lower values than those corresponding to the virgin materials. In order to achieve better results for recycled resins under impact, rubber must be added to the test specimens in addition to chopped fibers.

Based on the data from this research, recycled ABS and PC polymers in relation to virgin resins were found to retain at least $85 \%$ of their tensile, bending and compressive strength and stiffness properties. Proper design of recycled polymer blends with and without glass fibers has significant potential for nonstructural composite applications in infrastructure and automotive applications.

The results attained through this research are based on a first time recycling operation of the ABS and PC resins. The mechanical properties of these materials do change with additional recycling operations. Furthermore, aging and exposure to moisture during service of recycled polymers would further reduce these mechanical properties.

\section{What Have We Learned?}

- During creep testing, the blended and $100 \%$ recycled ABS specimen failed much sooner than the virgin specimen under identical sustained stresses. This is attributed to the fact that through the recycling operation, cross-linking within the ABS occurred along with the introduction of impurities into the material. Thus, ABS has become stiffer than the virgin resins, resulting in lower load to failure.

- Impurities within the blend and $100 \%$ recycled materials reduce the impact values significantly. As stated previously, addition of rubber along with fibers will 
reduce the effects of these impurities and allow the recycled material to produce better impact results compared to the virgin material.

- Virgin and first time recycled resins achieved similar results in tension, bending, compression, and hardness testing. Additional recycling operations will reduce the mechanical properties of the recycled resins due to factors such as water absorption, cross-linking, and oxidation of the ABS and PC polymers.

- First time recycling of ABS and PC polymers have similar mechanical properties in tension, bending, compression, and hardness as virgin materials. Therefore, these recycled ABS and PC resins would be suitable to replace virgin materials in automobile and infrastructure applications where color consistency is not a concern.

\subsection{Recommendations}

- The use of unidirectional fibers and effect of fiber volume fraction should be studied to characterize the increase in strength, stiffness and other mechanical properties of recycled ABS and PC.

- Further study is necessary for establishing a theoretical equation for the compressive modulus of random short-fiber composites using varying fiber volume fractions to validate the result..

- Care in manufacturing methods and sizing selection along with better processing, curing, and fiber compatibility need to be addressed in order to achieve better mechanical properties.

- Additional creep tests need to be conducted on both ABS and PC specimens to achieve a more precise creep coefficient of virgin, blend, and 100\% recycled 
specimens with and without fibers in terms of fiber volume fraction and fiber architecture.

- Further study is needed to determine the fatigue behavior of recycled plastics with and without fibers.

- Automotive applications require a class "A" glossy finish; therefore achieving the same with recycled plastics needs to be studied.

- Additional testing of recycled plastics in terms of crash-worthiness (Automobile 5 mph bumper impact tests) is needed.

- Further investigation is needed to develop mathematical models for predicting failure modes of recycled composites with and without fibers having different types of fillers (e.g. nanomers) and additives (e.g. fire retardants).

- The effect of secondary and tertiary recycling of plastics and its effect on mechanical properties needs additional study.

- Further evaluation of economical and environmental benefits in terms of lifecycle costs for recycled plastics is needed.

- Further study is necessary to determine the effects on the molecular and mechanical properties of recycling a material over and over. 


\section{REFERENCES}

1. Agarwal, B.D., Broutman, L.J., (1980), "Analysis and Performance of Fiber Composites," John Wiley \& Sons, NY.

2. Barbero, E.J., (1999), "Introduction to Composite Materials Design," Taylor \& Francis, Inc., PA.

3. BLI Series Operation Manual for Impact Testing (1999)

4. Durotronic Model 2000 Operating Manual (1999)

5. Eriksson, A., Boydell, P., Manson, A.E., Albertsson, C., (1997), "Durability Study of Recycled Glass-Fiber-Reinforced Polyamide 66 in a Service-Related Environment," Journal of Applied Polymer Science, Vol. 65, No. 8, Aug. 22, 1997.

6. Hibbler, R.C., (1994), "Mechanics of Materials," Prentice-Hall, Inc., NJ.

7. http://www.geplastics.com/resins/product/cycolac.html (2000)

8. http://www.geplastics.com/resins/product/lexan.html (2000)

9. Instron Series 8500 Two-Column Load Frame Operating Manual (1999)

10. Jones, R.M. (1999), "Mechanics of Composite Materials," Taylor \& Francis, Inc., PA.

11. Journal of Reinforced Plastics and Composites (Aug. 1992), Compressive Strength of Unidirectional Composites," p. 838-896.

12. "Just say no to e-waste: background document on hazards and waste from computers," Available: http://www.svtc.org/cleancc/eccc.htm

13. Liang, R. (1999), "Recycling of polymers," Literature Review, WVU.

14. Liang, R., West Virginia University, Personal Communication (2000) 
15. Mallick, P.K., (1993), "Fiber-Reinforced Composites Materials, Manufacturing, and Design," Marcel Dekker, Inc., NY

16. Modern Plastics (Jan. 2000) "For Tier 1 auto supplier, give and take is key to success," p. 160.

17. Modern Plastics (Jan. 2000) "Partnership helps injection molder penetrate new market segments," p. 32-33.

18. Powelson, D., Powelson, M. (1992) "The recycler's manual for business, government, and the environmental community," Van Nostrand Reinhold, New York.

19. Schweizer, B., Owens Corning Company, Personal Communication (2000)

20. Swartzbaugh, J., (1993) "Recycling equipment and technology for municipal solid waste: material recovery facilities," Noyes Data Corporation, Park Ridge, N.J.

21. Tall, S., Karlsson, S., Albertson, A. (1998) "Improvements in the properties of mechanically recycled thermoplastics," Polymer \& Polymer Composites, Vol. 6, No. $5,1998$.

22. Vijay, P.V., GangaRao, H.V.S., Bargo, J.E., (2000), "Mechanical Characterization of Recycled Thermoplastic Polymers for Infrastructure Applications," $3^{\text {rd }}$ International Conference on Advanced Composite Materials in Bridges and Structures, August 2000 


\section{APPENDIX-A}

\section{TENSION TEST RESULTS}

Table A-1 Tension Test Results for Virgin ABS

\begin{tabular}{|c|c|c|c|c|c|}
\hline Specimen & $\begin{array}{c}\text { Maximum } \\
\text { Load }\end{array}$ & $\begin{array}{c}\text { Maximum } \\
\text { Stress }\end{array}$ & $\begin{array}{c}\text { Strain @ } \\
\text { Max. Load }\end{array}$ & $\begin{array}{c}\text { Max. Strain } \\
\text { @ Failure }\end{array}$ & $\begin{array}{c}\text { Slope of the stress-strain } \\
\text { curve (Stiffness, E) }\end{array}$ \\
\hline & Ibs. & psi & $\%$ & $\%$ & psi \\
\hline TA1-1 & 391.17 & 6258.72 & 2.70 & 3.31 & $0.316 \mathrm{E}+06$ \\
\hline TA1-2 & 387.66 & 6202.56 & 2.86 & 5.36 & $0.319 \mathrm{E}+06$ \\
\hline TA1-3 & 385.44 & 6167.04 & 2.91 & 4.80 & $0.330 \mathrm{E}+06$ \\
\hline TA1-4 & 385.79 & 6172.64 & 2.99 & 4.81 & $0.320 \mathrm{E}+06$ \\
\hline TA1-5 & 379.36 & 6069.76 & 2.88 & 6.17 & $0.323 \mathrm{E}+06$ \\
\hline Average & $\mathbf{3 8 5 . 8 8}$ & $\mathbf{6 1 7 4 . 1 4}$ & $\mathbf{2 . 8 7}$ & $\mathbf{4 . 8 9}$ & $\mathbf{0 . 3 2 1 \mathrm { E } + \mathbf { 0 6 }}$ \\
\hline Std. Dev. & 4.30 & 68.76 & 0.11 & 1.05 & $0.551 \mathrm{E}+04$ \\
\hline
\end{tabular}

Table A-2 Tension Test Results for Virgin ABS with 25\% by Weight of Chopped Fibers

\begin{tabular}{|c|c|c|c|c|c|}
\hline Specimen & $\begin{array}{c}\text { Maximum } \\
\text { Load }\end{array}$ & $\begin{array}{c}\text { Maximum } \\
\text { Stress }\end{array}$ & $\begin{array}{c}\text { Strain @ } \\
\text { Max. Load }\end{array}$ & $\begin{array}{c}\text { Max. Strain } \\
\text { @ Failure }\end{array}$ & $\begin{array}{c}\text { Slope of the stress-strain } \\
\text { curve (Stiffness, E) }\end{array}$ \\
\hline & Ibs. & psi & $\%$ & $\%$ & psi \\
\hline TA2-1 & 624.80 & 9996.80 & 1.31 & 1.31 & $0.924 \mathrm{E}+06$ \\
\hline TA2-2 & 624.59 & 9993.44 & 1.31 & 1.69 & $0.966 \mathrm{E}+06$ \\
\hline TA2-3 & 646.96 & 10351.36 & 1.29 & 1.43 & $1.020 \mathrm{E}+06$ \\
\hline TA2-4 & 662.77 & 10604.32 & 1.42 & 1.67 & $0.979 \mathrm{E}+06$ \\
\hline TA2-5 & 659.45 & 10551.20 & 1.43 & 1.43 & $0.993 \mathrm{E}+06$ \\
\hline \hline Average & $\mathbf{6 4 3 . 7 1}$ & $\mathbf{1 0 2 9 9 . 4 2}$ & $\mathbf{1 . 3 5}$ & $\mathbf{1 . 5 1}$ & $\mathbf{0 . 9 7 6 E + 0 6}$ \\
\hline Std. Dev. & 18.34 & 293.37 & 0.07 & 0.17 & $3.530 \mathrm{E}+04$ \\
\hline
\end{tabular}

Table A-3 Tension Test Results for 100\% Recycled ABS

\begin{tabular}{|c|c|c|c|c|c|}
\hline Specimen & $\begin{array}{c}\text { Maximum } \\
\text { Load }\end{array}$ & $\begin{array}{c}\text { Maximum } \\
\text { Stress }\end{array}$ & $\begin{array}{c}\text { Strain @ } \\
\text { Max. Load }\end{array}$ & $\begin{array}{l}\text { Max. Strain } \\
\text { @ Failure }\end{array}$ & $\begin{array}{c}\text { Slope of the stress-strain } \\
\text { curve (Stiffness, E) }\end{array}$ \\
\hline & lbs. & psi & $\%$ & $\%$ & psi \\
\hline TA3-1 & 354.64 & 5674.24 & 2.83 & 5.02 & $0.348 \mathrm{E}+06$ \\
\hline TA3-2 & 347.97 & 5567.52 & 2.91 & 6.49 & $0.338 \mathrm{E}+06$ \\
\hline TA3-3 & 347.86 & 5565.76 & 2.82 & 5.37 & $0.338 \mathrm{E}+06$ \\
\hline TA3-4 & 347.15 & 5554.40 & 3.02 & 7.42 & $0.329 \mathrm{E}+06$ \\
\hline TA3-5 & 345.77 & 5532.32 & 2.68 & 8.09 & $0.314 \mathrm{E}+06$ \\
\hline Average & 348.68 & 5578.85 & 2.85 & 6.48 & $0.333 E+06$ \\
\hline Std. Dev. & 3.45 & 55.14 & 0.13 & 1.31 & $1.274 \mathrm{E}+04$ \\
\hline
\end{tabular}


Table A-4 Tension Test Results for $100 \%$ Recycled ABS with $25 \%$ by Weight of Chopped Fibers

\begin{tabular}{|c|c|c|c|c|c|}
\hline Specimen & $\begin{array}{c}\text { Maximum } \\
\text { Load }\end{array}$ & $\begin{array}{l}\text { Maximum } \\
\text { Stress }\end{array}$ & $\begin{array}{c}\text { Strain @ } \\
\text { Max. Load }\end{array}$ & $\begin{array}{l}\text { Max. Strain } \\
\text { @ Failure }\end{array}$ & $\begin{array}{c}\text { Slope of the stress-strain } \\
\text { curve (Stiffness, E) }\end{array}$ \\
\hline & Ibs. & psi & $\%$ & $\%$ & psi \\
\hline TA4-1 & 515.56 & 8248.96 & 1.06 & 1.06 & $0.926 \mathrm{E}+06$ \\
\hline TA4-2 & 563.76 & 9020.16 & 1.20 & 1.20 & $0.926 \mathrm{E}+06$ \\
\hline TA4-3 & 548.06 & 8768.96 & 1.10 & 1.10 & $0.964 \mathrm{E}+06$ \\
\hline TA4-4 & 563.87 & 9021.92 & 1.13 & 1.13 & $1.020 \mathrm{E}+06$ \\
\hline TA4-5 & 558.92 & 8942.72 & 1.13 & 1.13 & $0.984 \mathrm{E}+06$ \\
\hline Average & 550.03 & 8800.54 & $\overline{1.12}$ & 1.12 & $0.964 E+06$ \\
\hline Std. Dev. & 20.32 & 325.07 & 0.05 & 0.05 & $4.018 \mathrm{E}+04$ \\
\hline
\end{tabular}

Table A-5 Tension Test Results for ABS Polymer Blend

\begin{tabular}{|c|c|c|c|c|c|}
\hline Specimen & $\begin{array}{c}\text { Maximum } \\
\text { Load }\end{array}$ & $\begin{array}{c}\text { Maximum } \\
\text { Stress }\end{array}$ & $\begin{array}{c}\text { Strain @ } \\
\text { Max. Load }\end{array}$ & $\begin{array}{c}\text { Max. Strain } \\
\text { @ Failure }\end{array}$ & $\begin{array}{c}\text { Slope of the stress-strain } \\
\text { curve (Stiffness, E) }\end{array}$ \\
\hline & Ibs. & psi & $\%$ & $\%$ & psi \\
\hline TA5-1 & 384.18 & 6146.88 & 2.53 & 2.64 & $0.404 \mathrm{E}+06$ \\
\hline TA5-2 & 369.58 & 5913.28 & 2.77 & 4.03 & $0.371 \mathrm{E}+06$ \\
\hline TA5-3 & 363.50 & 5816.00 & 2.99 & 6.10 & $0.336 \mathrm{E}+06$ \\
\hline TA5-4 & 361.86 & 5789.76 & 2.85 & 7.50 & $0.336 \mathrm{E}+06$ \\
\hline TA5-5 & 369.61 & 5913.76 & 2.67 & 6.38 & $0.349 \mathrm{E}+06$ \\
\hline \hline Average & $\mathbf{3 6 9 . 7 5}$ & $\mathbf{5 9 1 5 . 9 4}$ & $\mathbf{2 . 7 6}$ & $\mathbf{5 . 3 3}$ & $\mathbf{0 . 3 5 9 E + 0 6}$ \\
\hline Std. Dev. & 8.80 & 140.76 & 0.17 & 1.96 & $2.874 \mathrm{E}+04$ \\
\hline
\end{tabular}

Table A-6 Tension Test Results for ABS Polymer Blend with 25\% by Weight of Chopped Fibers

\begin{tabular}{|c|c|c|c|c|c|}
\hline Specimen & $\begin{array}{l}\text { Maximum } \\
\text { Load }\end{array}$ & $\begin{array}{l}\text { Maximum } \\
\text { Stress }\end{array}$ & $\begin{array}{l}\text { Strain @ } \\
\text { Max. Load }\end{array}$ & $\begin{array}{l}\text { Max. Strain } \\
\text { @ Failure }\end{array}$ & $\begin{array}{l}\text { Slope of the stress-strain } \\
\text { curve (Stiffness, E) }\end{array}$ \\
\hline & Ibs. & psi & $\%$ & $\%$ & psi \\
\hline TA6-1 & 565.20 & 9043.20 & 1.27 & 1.27 & $0.885 \mathrm{E}+06$ \\
\hline TA6-3 & 516.54 & 8264.64 & 1.20 & 1.20 & $0.848 \mathrm{E}+06$ \\
\hline TA6-4 & 556.12 & 8897.92 & 1.20 & 1.20 & $0.907 \mathrm{E}+06$ \\
\hline TA6-5 & 576.83 & 9229.28 & 1.12 & 1.12 & $1.014 \mathrm{E}+06$ \\
\hline TA6-6 & 570.12 & 9121.92 & 1.10 & 1.10 & $1.048 \mathrm{E}+06$ \\
\hline Average & 556.96 & 8911.39 & 1.18 & 1.18 & 0.941E+06 \\
\hline Std. Dev. & 23.82 & 381.19 & 0.07 & 0.07 & $8.609 \mathrm{E}+04$ \\
\hline
\end{tabular}


Table A-7 Tension Test Results for Virgin PC

\begin{tabular}{|c|c|c|c|c|c|c|}
\hline Specimen & $\begin{array}{c}\text { Maximum } \\
\text { Load }\end{array}$ & $\begin{array}{c}\text { Maximum } \\
\text { Stress }\end{array}$ & $\begin{array}{c}\text { Strain @ } \\
\text { Max. Load }\end{array}$ & $\begin{array}{c}\text { Max. Strain } \\
\text { @ Failure }\end{array}$ & \multicolumn{2}{c|}{$\begin{array}{c}\text { Slope of the stress-strain } \\
\text { curve (Stiffness, E) }\end{array}$} \\
\hline & Ibs. & psi & $\%$ & $\%$ & \multicolumn{2}{|c|}{ psi } \\
\hline & & & & & E1 & E2 \\
\hline TP1-1 & 560.40 & 8730.06 & 7.50 & 10.75 & $0.300 \mathrm{E}+06$ & $0.146 \mathrm{E}+06$ \\
\hline TP1-2 & 555.16 & 8648.43 & 7.32 & 9.97 & $0.305 \mathrm{E}+06$ & $0.147 \mathrm{E}+06$ \\
\hline TP1-3 & 553.52 & 8622.88 & 7.22 & 10.39 & $0.297 \mathrm{E}+06$ & $0.145 \mathrm{E}+06$ \\
\hline TP1-4 & 555.86 & 8659.33 & 7.31 & 8.00 & $0.299 \mathrm{E}+06$ & $0.147 \mathrm{E}+06$ \\
\hline TP1-5 & 556.10 & 8663.07 & 7.00 & 10.50 & $0.298 \mathrm{E}+06$ & $0.148 \mathrm{E}+06$ \\
\hline \hline Average & $\mathbf{5 5 6 . 2 1}$ & $\mathbf{8 6 6 4 . 7 6}$ & $\mathbf{7 . 2 7}$ & $\mathbf{9 . 9 2}$ & $\mathbf{0 . 3 0 0 E + 0 6}$ & $\mathbf{0 . 1 4 7 E + 0 6}$ \\
\hline Std. Dev. & 2.55 & 39.74 & 0.18 & 1.11 & $0.321 \mathrm{E}+04$ & $0.114 \mathrm{E}+04$ \\
\hline
\end{tabular}

Table A-8 Tension Test Results for Virgin PC with $25 \%$ by Weight of Chopped Fibers

\begin{tabular}{|c|c|c|c|c|c|c|}
\hline Specimen & $\begin{array}{c}\text { Maximum } \\
\text { Load }\end{array}$ & $\begin{array}{c}\text { Maximum } \\
\text { Stress }\end{array}$ & $\begin{array}{c}\text { Strain @ } \\
\text { Max. Load }\end{array}$ & $\begin{array}{c}\text { Max. Strain } \\
\text { @ Failure }\end{array}$ & \multicolumn{2}{c|}{$\begin{array}{c}\text { Slope of the stress-strain } \\
\text { curve (Stiffness, E) }\end{array}$} \\
\hline & Ibs. & psi & $\%$ & $\%$ & \multicolumn{2}{|c|}{ psi } \\
\hline & & & & & E1 & E2 \\
\hline TP2-2 & 1062.49 & 16551.75 & 2.96 & 3.11 & $1.063 \mathrm{E}+06$ & $0.450 \mathrm{E}+06$ \\
\hline TP2-3 & 1058.43 & 16488.50 & 3.28 & 3.33 & $1.007 \mathrm{E}+06$ & $0.420 \mathrm{E}+06$ \\
\hline TP2-4 & 1057.02 & 16466.54 & 3.12 & 3.23 & $1.009 \mathrm{E}+06$ & $0.424 \mathrm{E}+06$ \\
\hline TP2-5 & 1055.00 & 16435.07 & 3.13 & 3.23 & $1.037 \mathrm{E}+06$ & $0.428 \mathrm{E}+06$ \\
\hline TP2-6 & 1056.18 & 16453.45 & 3.21 & 3.25 & $1.031 \mathrm{E}+06$ & $0.435 \mathrm{E}+06$ \\
\hline Average & $\mathbf{1 0 5 7 . 8 2}$ & $\mathbf{1 6 4 7 9 . 0 6}$ & $\mathbf{3 . 1 4}$ & $\mathbf{3 . 2 3}$ & $\mathbf{1 . 0 2 9 E + 0 6}$ & $\mathbf{0 . 4 3 1 E + 0 6}$ \\
\hline Std. Dev. & 2.89 & 45.06 & 0.12 & 0.08 & $2.267 \mathrm{E}+04$ & $1.178 \mathrm{E}+04$ \\
\hline
\end{tabular}

Table A-9 Tension Test Results for $100 \%$ Recycled PC

\begin{tabular}{|c|c|c|c|c|c|c|}
\hline Specimen & $\begin{array}{c}\text { Maximum } \\
\text { Load }\end{array}$ & $\begin{array}{c}\text { Maximum } \\
\text { Stress }\end{array}$ & $\begin{array}{c}\text { Strain @ } \\
\text { Max. Load }\end{array}$ & $\begin{array}{c}\text { Max. Strain } \\
\text { @ Failure }\end{array}$ & $\begin{array}{c}\text { Slope of the stress-strain } \\
\text { curve (Stiffness, E) }\end{array}$ \\
\hline & Ibs. & psi & $\%$ & $\%$ & \multicolumn{2}{|c|}{ psi } \\
\hline & & & & & E1 & E2 \\
\hline TP3-1 & 550.91 & 8582.22 & 7.58 & 8.89 & $0.291 \mathrm{E}+06$ & $0.137 \mathrm{E}+06$ \\
\hline TP3-2 & 550.48 & 8575.52 & 7.33 & 9.85 & $0.288 \mathrm{E}+06$ & $0.138 \mathrm{E}+06$ \\
\hline TP3-3 & 548.60 & 8546.24 & 7.61 & 9.82 & $0.291 \mathrm{E}+06$ & $0.140 \mathrm{E}+06$ \\
\hline TP3-4 & 550.45 & 8575.06 & 6.91 & 9.63 & $0.307 \mathrm{E}+06$ & $0.138 \mathrm{E}+06$ \\
\hline TP3-5 & 548.92 & 8551.22 & 7.23 & 9.53 & $0.289 \mathrm{E}+06$ & $0.141 \mathrm{E}+06$ \\
\hline \hline Average & $\mathbf{5 4 9 . 8 7}$ & $\mathbf{8 5 6 6 . 0 5}$ & $\mathbf{7 . 3 3}$ & $\mathbf{9 . 5 4}$ & $\mathbf{0 . 2 9 3 E + 0 6}$ & $\mathbf{0 . 1 3 9 E + 0 6}$ \\
\hline Std. Dev. & 1.04 & 16.16 & 0.29 & 0.39 & $0.792 \mathrm{E}+04$ & $0.164 \mathrm{E}+04$ \\
\hline
\end{tabular}


Table A-10 Tension Test Results for $100 \%$ Recycled ABS with $25 \%$ by Weight of Chopped Fibers

\begin{tabular}{|c|c|c|c|c|c|c|}
\hline Specimen & $\begin{array}{c}\text { Maximum } \\
\text { Load }\end{array}$ & $\begin{array}{c}\text { Maximum } \\
\text { Stress }\end{array}$ & $\begin{array}{c}\text { Strain @ } \\
\text { Max. Load }\end{array}$ & $\begin{array}{c}\text { Max. Strain } \\
\text { @ Failure }\end{array}$ & $\begin{array}{c}\text { Slope of the stress-strain } \\
\text { curve (Stiffness, E) }\end{array}$ \\
\hline & lbs. & psi & $\%$ & $\%$ & \multicolumn{2}{|c|}{ psi } \\
\hline & & & & & E1 & E2 \\
\hline TP4-1 & 978.29 & 15240.06 & 2.80 & 2.85 & $0.967 \mathrm{E}+06$ & $0.422 \mathrm{E}+06$ \\
\hline TP4-2 & 976.94 & 15219.03 & 2.66 & 3.11 & $1.008 \mathrm{E}+06$ & $0.433 \mathrm{E}+06$ \\
\hline TP4-3 & 973.31 & 15162.48 & 2.61 & 2.97 & $0.987 \mathrm{E}+06$ & $0.408 \mathrm{E}+06$ \\
\hline TP4-4 & 977.41 & 15226.35 & 2.68 & 2.71 & $1.007 \mathrm{E}+06$ & $0.412 \mathrm{E}+06$ \\
\hline TP4-5 & 976.97 & 15219.50 & 2.63 & 3.15 & $0.997 \mathrm{E}+06$ & $0.411 \mathrm{E}+06$ \\
\hline Average & $\mathbf{9 7 6 . 5 8}$ & $\mathbf{1 5 2 1 3 . 4 8}$ & $\mathbf{2 . 6 8}$ & $\mathbf{2 . 9 6}$ & $\mathbf{0 . 9 9 3 E + 0 6}$ & $\mathbf{0 . 4 1 7 E + 0 6}$ \\
\hline Std. Dev. & 1.91 & 29.75 & 0.07 & 0.18 & $1.694 \mathrm{E}+04$ & $1.028 \mathrm{E}+04$ \\
\hline
\end{tabular}

Table A-11 Tension Test Results for PC Polymer Blend

\begin{tabular}{|c|c|c|c|c|c|c|}
\hline Specimen & $\begin{array}{c}\text { Maximum } \\
\text { Load }\end{array}$ & $\begin{array}{c}\text { Maximum } \\
\text { Stress }\end{array}$ & $\begin{array}{c}\text { Strain @ } \\
\text { Max. Load }\end{array}$ & $\begin{array}{c}\text { Max. Strain } \\
\text { @ Failure }\end{array}$ & \multicolumn{2}{c|}{$\begin{array}{c}\text { Slope of the stress-strain } \\
\text { curve (Stiffness, E) }\end{array}$} \\
\hline & Ibs. & psi & $\%$ & $\%$ & \multicolumn{2}{|c|}{ psi } \\
\hline & & & & & E1 & E2 \\
\hline TP5-1 & 573.71 & 8937.41 & 6.79 & 8.20 & $0.350 \mathrm{E}+06$ & $0.172 \mathrm{E}+06$ \\
\hline TP5-2 & 570.93 & 8894.10 & 7.34 & 9.35 & $0.313 \mathrm{E}+06$ & $0.165 \mathrm{E}+06$ \\
\hline TP5-3 & 573.16 & 8928.84 & 6.98 & 9.19 & $0.323 \mathrm{E}+06$ & $0.166 \mathrm{E}+06$ \\
\hline TP5-4 & 573.39 & 8932.42 & 7.07 & 9.18 & $0.327 \mathrm{E}+06$ & $0.171 \mathrm{E}+06$ \\
\hline TP5-5 & 573.84 & 8939.43 & 6.99 & 9.30 & $0.330 \mathrm{E}+06$ & $0.172 \mathrm{E}+06$ \\
\hline Average & $\mathbf{5 7 3 . 0 1}$ & $\mathbf{8 9 2 6 . 4 4}$ & $\mathbf{7 . 0 3}$ & $\mathbf{9 . 0 4}$ & $\mathbf{0 . 3 2 9 E + 0 6}$ & $\mathbf{0 . 1 6 9 E + 0 6}$ \\
\hline Std. Dev. & 1.19 & 18.55 & 0.20 & 0.48 & $1.360 \mathrm{E}+04$ & $0.342 \mathrm{E}+04$ \\
\hline
\end{tabular}

Table A-12 Tension Test Results for PC Polymer Blend with 25\% by Weight of Chopped Fibers

\begin{tabular}{|c|c|c|c|c|c|c|}
\hline Specimen & $\begin{array}{c}\text { Maximum } \\
\text { Load }\end{array}$ & $\begin{array}{c}\text { Maximum } \\
\text { Stress }\end{array}$ & $\begin{array}{c}\text { Strain @ } \\
\text { Max. Load }\end{array}$ & $\begin{array}{c}\text { Max. Strain } \\
\text { @ Failure }\end{array}$ & $\begin{array}{c}\text { Slope of the stress-strain } \\
\text { curve (Stiffness, E) }\end{array}$ \\
\hline & lbs. & psi & $\%$ & $\%$ & \multicolumn{2}{|c|}{ psi } \\
\hline & & & & & E1 & E2 \\
\hline TP6-1 & 1059.03 & 16497.85 & 2.88 & 2.94 & $1.077 \mathrm{E}+06$ & $0.489 \mathrm{E}+06$ \\
\hline TP6-2 & 1065.02 & 16591.16 & 3.11 & 3.43 & $1.025 \mathrm{E}+06$ & $0.478 \mathrm{E}+06$ \\
\hline TP6-3 & 1064.92 & 16589.61 & 2.98 & 3.04 & $1.031 \mathrm{E}+06$ & $0.492 \mathrm{E}+06$ \\
\hline TP6-4 & 1061.61 & 16538.04 & 2.83 & 3.53 & $1.048 \mathrm{E}+06$ & $0.501 \mathrm{E}+06$ \\
\hline TP6-5 & 1063.14 & 16561.88 & 2.94 & 3.37 & $1.052 \mathrm{E}+06$ & $0.489 \mathrm{E}+06$ \\
\hline Average & $\mathbf{1 0 6 2 . 7 4}$ & $\mathbf{1 6 5 5 5 . 7 1}$ & $\mathbf{2 . 9 5}$ & $\mathbf{3 . 2 6}$ & $\mathbf{1 . 0 4 6 \mathrm { E } + 0 6}$ & $\mathbf{0 . 4 9 0 \mathrm { E } + 0 6}$ \\
\hline Std. Dev. & 2.51 & 39.06 & 0.11 & 0.26 & $2.039 \mathrm{E}+04$ & $0.823 \mathrm{E}+04$ \\
\hline
\end{tabular}




\section{APPENDIX-B}

\section{BENDING TEST RESULTS}

Table B-1 Bending Test Results for Virgin ABS

\begin{tabular}{|c|c|c|c|c|c|}
\hline Specimen & $\begin{array}{c}\text { Maximum } \\
\text { Load }\end{array}$ & $\begin{array}{c}\text { Maximum } \\
\text { Stress }\end{array}$ & $\begin{array}{c}\text { Deflection @ } \\
\text { Max. Stress }\end{array}$ & $\begin{array}{c}\text { Max. Deflection } \\
\text { Recorded }\end{array}$ & Stiffness, E \\
\hline & Ibs. & psi & in. & in. & psi \\
\hline BA1-12 & 10.54 & 7588.80 & 0.62 & 1.30 & \multirow{2}{*}{$0.42 \mathrm{E}+06$} \\
\hline BA1-13 & 13.35 & 9612.00 & 0.72 & 1.42 & \multirow{2}{*}{$0.38 \mathrm{E}+06$} \\
\hline BA1-14 & 13.58 & 9777.60 & 0.71 & 1.42 & \\
\hline BA1-15 & 13.25 & 9540.00 & 0.68 & 1.16 & \\
\hline BA1-17 & 11.47 & 8258.40 & 0.67 & 1.40 & \\
\hline BA1-18 & 12.53 & 9021.60 & 0.64 & 1.42 & \multirow{2}{*}{$\mathbf{0 . 4 0 E + 0 6}$} \\
\hline BA1-19 & 13.56 & 9763.20 & 0.69 & 1.22 & - \\
\hline \hline Average & $\mathbf{1 2 . 6 1}$ & $\mathbf{9 0 8 0 . 2 3}$ & $\mathbf{0 . 6 7}$ & - & - \\
\cline { 1 - 4 } Std. Dev. & 1.09 & 788.32 & 0.04 & - & \\
\hline
\end{tabular}

Table B-2 Bending Test Results for Virgin ABS with $25 \%$ by Weight of Chopped Fibers

\begin{tabular}{|c|c|c|c|c|c|}
\hline Specimen & $\begin{array}{l}\text { Maximum } \\
\text { Load }\end{array}$ & $\begin{array}{l}\text { Maximum } \\
\text { Stress }\end{array}$ & $\begin{array}{l}\text { Deflection @ } \\
\text { Max.Stress }\end{array}$ & $\begin{array}{l}\text { Max. Deflection } \\
\text { Recorded }\end{array}$ & Stiffness, E \\
\hline & Ibs. & psi & in. & in. & psi \\
\hline BA2-11 & 24.94 & 17956.80 & 0.45 & 0.47 & \multirow{5}{*}{$\begin{array}{l}1.05 \mathrm{E}+06 \\
0.99 \mathrm{E}+06\end{array}$} \\
\hline BA2-12 & 25.06 & 18043.20 & 0.49 & 0.52 & \\
\hline BA2-13 & 24.00 & 17280.00 & 0.51 & 0.51 & \\
\hline BA2-16 & 24.82 & 17870.40 & 0.50 & 0.52 & \\
\hline BA2-17 & 24.59 & 17704.80 & 0.53 & 0.54 & \\
\hline Average & 24.68 & 17771.04 & 0.50 & - & $1.02 \mathrm{E}+06$ \\
\hline Std. Dev. & 0.37 & 269.80 & 0.03 & - & - \\
\hline
\end{tabular}

Table B-3 Bending Test Results for 100\% Recycled ABS

\begin{tabular}{|c|c|c|c|c|c|}
\hline Specimen & $\begin{array}{c}\text { Maximum } \\
\text { Load }\end{array}$ & $\begin{array}{c}\text { Maximum } \\
\text { Stress }\end{array}$ & $\begin{array}{c}\text { Deflection @ } \\
\text { Max. Stress }\end{array}$ & $\begin{array}{c}\text { Max. Deflection } \\
\text { Recorded }\end{array}$ & Stiffness, E \\
\hline & Ibs. & psi & in. & in. & psi \\
\hline BA3-12 & 13.93 & 10029.60 & 0.70 & 1.41 & \multirow{2}{*}{$0.42 \mathrm{E}+06$} \\
\hline BA3-13 & 14.40 & 10368.00 & 0.84 & 1.48 & $0.38 \mathrm{E}+06$ \\
\hline BA3-15 & 11.12 & 8006.40 & 0.62 & 1.38 & \\
\hline BA3-17 & 11.47 & 8258.40 & 0.57 & 1.39 & \\
\hline BA3-18 & 12.88 & 9273.60 & 0.70 & 1.48 & \multirow{2}{*}{$\mathbf{0 . 4 0 E + 0 6}$} \\
\hline Average & $\mathbf{1 2 . 7 6}$ & $\mathbf{9 1 8 7 . 2 0}$ & $\mathbf{0 . 6 9}$ & - & - \\
\hline Std. Dev. & 2.43 & 1749.19 & 0.10 & - & \\
\hline
\end{tabular}


Table B-4 Bending Test Results for $100 \%$ Recycled ABS with $25 \%$ by Weight of Chopped Fibers

\begin{tabular}{|c|c|c|c|c|c|}
\hline Specimen & $\begin{array}{l}\text { Maximum } \\
\text { Load }\end{array}$ & $\begin{array}{l}\text { Maximum } \\
\text { Stress }\end{array}$ & $\begin{array}{l}\text { Deflection @ } \\
\text { Max.Stress }\end{array}$ & $\begin{array}{l}\text { Max. Deflection } \\
\text { Recorded }\end{array}$ & Stiffness, E \\
\hline & Ibs. & psi & in. & in. & psi \\
\hline BA4-11 & 21.54 & 15508.80 & 0.51 & 0.51 & \multirow{5}{*}{$\begin{array}{l}1.11 \mathrm{E}+06 \\
1.04 \mathrm{E}+06\end{array}$} \\
\hline BA4-12 & 24.59 & 17704.80 & 0.49 & 0.49 & \\
\hline BA4-13 & 23.65 & 17028.00 & 0.46 & 0.46 & \\
\hline BA4-16 & 21.89 & 15760.80 & 0.46 & 0.48 & \\
\hline BA4-17 & 24.58 & 17697.60 & 0.49 & 0.50 & \\
\hline Average & 23.25 & 16740.00 & 0.48 & - & $1.08 \mathrm{E}+06$ \\
\hline Std. Dev. & 1.46 & 1049.46 & 0.02 & - & - \\
\hline
\end{tabular}

Table B-5 Bending Test Results for ABS Polymer Blend

\begin{tabular}{|c|c|c|c|c|c|}
\hline Specimen & $\begin{array}{c}\text { Maximum } \\
\text { Load }\end{array}$ & $\begin{array}{c}\text { Maximum } \\
\text { Stress }\end{array}$ & $\begin{array}{c}\text { Deflection @ } \\
\text { Max. Stress }\end{array}$ & $\begin{array}{c}\text { Max. Deflection } \\
\text { Recorded }\end{array}$ & Stiffness, E \\
\hline & lbs. & psi & in. & in. & psi \\
\hline BA5-11 & 12.41 & 8935.20 & 0.70 & 1.38 & $0.43 E+06$ \\
\hline BA5-12 & 13.58 & 9777.60 & 0.68 & 1.43 & $0.38 \mathrm{E}+06$ \\
\hline BA5-13 & 13.82 & 9950.40 & 0.68 & 1.47 & \\
\hline BA5-16 & 13.46 & 9691.20 & 0.73 & 1.41 & \\
\hline BA5-17 & 13.11 & 9439.20 & 0.69 & 1.37 & \\
\hline \hline Average & $\mathbf{1 3 . 2 8}$ & $\mathbf{9 5 5 8 . 7 2}$ & $\mathbf{0 . 7 0}$ & - & $\mathbf{0 . 4 0 E + 0 6}$ \\
\hline Std. Dev. & 0.55 & 394.31 & 0.02 & - & - \\
\hline
\end{tabular}

Table B-6 Bending Test Results for ABS Polymer Blend with 25\% by Weight of Chopped Fibers

\begin{tabular}{|c|c|c|c|c|c|}
\hline Specimen & $\begin{array}{l}\text { Maximum } \\
\text { Load }\end{array}$ & $\begin{array}{l}\text { Maximum } \\
\text { Stress }\end{array}$ & $\begin{array}{c}\text { Deflection @ } \\
\text { Max.Stress }\end{array}$ & $\begin{array}{l}\text { Max. Deflection } \\
\text { Recorded }\end{array}$ & Stiffness, E \\
\hline & Ibs. & psi & in. & in. & psi \\
\hline BA6-11 & 21.08 & 15177.60 & 0.49 & 0.49 & \multirow{6}{*}{$\begin{array}{l}1.15 \mathrm{E}+06 \\
1.08 \mathrm{E}+06\end{array}$} \\
\hline BA6-12 & 22.95 & 16524.00 & 0.44 & 0.44 & \\
\hline BA6-13 & 23.88 & 17193.60 & 0.55 & 0.56 & \\
\hline BA6-15 & 23.42 & 16862.40 & 0.47 & 0.48 & \\
\hline BA6-17 & 23.77 & 17114.40 & 0.45 & 0.46 & \\
\hline BA6-18 & 22.48 & 16185.60 & 0.45 & 0.46 & \\
\hline Average & 22.93 & 16509.60 & 0.47 & - & 1.11E+06 \\
\hline Std. Dev. & 1.05 & 753.33 & 0.04 & - & - \\
\hline
\end{tabular}


Table B-7 Bending Test Results for Virgin PC

\begin{tabular}{|c|c|c|c|c|c|}
\hline Specimen & $\begin{array}{c}\text { Maximum } \\
\text { Load } \\
\text { Ibs. }\end{array}$ & $\begin{array}{c}\text { Maximum } \\
\text { Stress } \\
\text { psi }\end{array}$ & $\begin{array}{c}\text { Deflection @ } \\
\text { Max. Stress }\end{array}$ & $\begin{array}{c}\text { Max. Deflection } \\
\text { in. }\end{array}$ & Stiffness, E \\
\hline & 13.70 & 9864.00 & 0.81 & 1.43 & psi \\
\hline BP1-6 & 13.19 & 10216.80 & 0.94 & 1.21 & $0.329 \mathrm{E}+06$ \\
\hline BP1-7 & 14.19 & 0.94 & 1.16 & $0.345 \mathrm{E}+06$ \\
\hline BP1-8 & 13.98 & 10065.60 & 0.83 & 1.34 & $0.355 \mathrm{E}+06$ \\
\hline BP1-9 & 15.04 & 10828.80 & 0.83 & $0.329 \mathrm{E}+06$ \\
\hline BP1-10 & 14.22 & 10238.40 & 0.81 & 1.29 & $\mathbf{0 . 3 3 2 E + 0 6}$ \\
\hline Average & $\mathbf{1 4 . 2 3}$ & $\mathbf{1 0 2 4 2 . 7 2}$ & $\mathbf{0 . 8 7}$ & - & $2.022 \mathrm{E}+04$ \\
\hline Std. Dev. & 0.50 & 360.20 & 0.07 & - & \\
\hline
\end{tabular}

Table B-8 Bending Test Results for Virgin PC with $25 \%$ by Weight of Chopped Fibers

\begin{tabular}{|c|c|c|c|c|c|}
\hline Specimen & $\begin{array}{l}\text { Maximum } \\
\text { Load }\end{array}$ & $\begin{array}{l}\text { Maximum } \\
\text { Stress }\end{array}$ & $\begin{array}{l}\text { Deflection @ } \\
\text { Max.Stress }\end{array}$ & $\begin{array}{l}\text { Max. Deflection } \\
\text { Recorded }\end{array}$ & Stiffness, E \\
\hline & Ibs. & psi & in. & in. & psi \\
\hline BP2-6 & 33.90 & 24408.00 & 0.73 & 0.80 & $0.929 \mathrm{E}+06$ \\
\hline BP2-7 & 34.69 & 24976.80 & 0.78 & 0.82 & $1.009 \mathrm{E}+06$ \\
\hline BP2-8 & 34.22 & 24638.40 & 0.79 & 0.82 & $0.956 \mathrm{E}+06$ \\
\hline BP2-9 & 34.07 & 24530.40 & 0.84 & 0.84 & $0.981 E+06$ \\
\hline BP2-10 & 33.72 & 24278.40 & 0.75 & 0.79 & $0.961 E+06$ \\
\hline Average & 34.12 & 24566.40 & 0.78 & - & $0.967 E+06$ \\
\hline Std. Dev. & 0.37 & 265.96 & 0.04 & - & $2.974 \mathrm{E}+04$ \\
\hline
\end{tabular}

Table B-9 Bending Test Results for 100\% Recycled PC

\begin{tabular}{|c|c|c|c|c|c|}
\hline Specimen & $\begin{array}{c}\text { Maximum } \\
\text { Load }\end{array}$ & $\begin{array}{c}\text { Maximum } \\
\text { Stress }\end{array}$ & $\begin{array}{c}\text { Deflection @ } \\
\text { Max. Stress }\end{array}$ & $\begin{array}{c}\text { Max. Deflection } \\
\text { Recorded }\end{array}$ & Stiffness, E \\
\hline & Ibs. & psi & in. & in. & psi \\
\hline BP3-6 & 14.28 & 10281.60 & 0.87 & 1.26 & $0.302 \mathrm{E}+06$ \\
\hline BP3-7 & 14.10 & 10152.00 & 0.77 & 1.28 & $0.289 \mathrm{E}+06$ \\
\hline BP3-8 & 14.99 & 10792.80 & 0.73 & 1.47 & $0.297 \mathrm{E}+06$ \\
\hline BP3-9 & 14.75 & 10620.00 & 0.93 & 1.44 & $0.281 \mathrm{E}+06$ \\
\hline BP3-10 & 13.85 & 9972.00 & 0.73 & 1.33 & $0.286 \mathrm{E}+06$ \\
\hline \hline Average & $\mathbf{1 4 . 3 9}$ & $\mathbf{1 0 3 6 3 . 6 8}$ & $\mathbf{0 . 8 1}$ & - & $\mathbf{0 . 2 9 1 E + 0 6}$ \\
\hline Std. Dev. & 0.47 & 337.20 & 0.09 & - & $0.860 \mathrm{E}+04$ \\
\hline
\end{tabular}


Table B-10 Bending Test Results for $100 \%$ Recycled PC with $25 \%$ by Weight of Chopped Fibers

\begin{tabular}{|c|c|c|c|c|c|}
\hline Specimen & $\begin{array}{c}\text { Maximum } \\
\text { Load }\end{array}$ & $\begin{array}{c}\text { Maximum } \\
\text { Stress }\end{array}$ & $\begin{array}{c}\text { Deflection @ } \\
\text { Max. Stress }\end{array}$ & $\begin{array}{c}\text { Max. Deflection } \\
\text { Recorded }\end{array}$ & Stiffness, E \\
\hline & Ibs. & psi & in. & in. & psi \\
\hline BP4-6 & 32.55 & 23436.00 & 0.66 & 0.67 & $0.864 \mathrm{E}+06$ \\
\hline BP4-7 & 32.17 & 23162.40 & 0.65 & 0.69 & $0.909 \mathrm{E}+06$ \\
\hline BP4-8 & 32.50 & 23400.00 & 0.68 & 0.71 & $0.958 \mathrm{E}+06$ \\
\hline BP4-9 & 32.03 & 23061.60 & 0.67 & 0.73 & $0.928 \mathrm{E}+06$ \\
\hline BP4-10 & 31.85 & 22932.00 & 0.66 & 0.70 & $0.924 \mathrm{E}+06$ \\
\hline \hline Average & $\mathbf{3 2 . 2 2}$ & $\mathbf{2 3 1 9 8 . 4 0}$ & $\mathbf{0 . 6 6}$ & - & $\mathbf{0 . 9 1 6 E + 0 6}$ \\
\hline Std. Dev. & 0.30 & 216.84 & 0.01 & - & $3.424 \mathrm{E}+04$ \\
\hline
\end{tabular}

Table B-11 Bending Test Results for PC Polymer Blend

\begin{tabular}{|c|c|c|c|c|c|}
\hline Specimen & $\begin{array}{c}\text { Maximum } \\
\text { Load } \\
\text { Ibs. }\end{array}$ & $\begin{array}{c}\text { Maximum } \\
\text { Stress }\end{array}$ & $\begin{array}{c}\text { Deflection @ } \\
\text { Max. Stress }\end{array}$ & $\begin{array}{c}\text { Max. Deflection } \\
\text { Recorded }\end{array}$ & Stiffness, E \\
\hline & 14.81 & 10663.20 & 0.79 & in. & psi \\
\hline BP5-6 & 15.25 & 10980.00 & 0.95 & 1.31 & $0.303 \mathrm{E}+06$ \\
\hline BP5-7 & 15.43 & 11109.60 & 0.79 & 1.38 & $0.338 \mathrm{E}+06$ \\
\hline BP5-8 & 16.27 & 11714.40 & 0.99 & 1.47 & $0.343 \mathrm{E}+06$ \\
\hline BP5-9 & 15.80 & 11376.00 & 0.96 & 1.43 & $0.326 \mathrm{E}+06$ \\
\hline BP5-10 & $\mathbf{1 1 1 6 8 . 6 4}$ & $\mathbf{0 . 9 0}$ & - & $0.326 \mathrm{E}+06$ \\
\hline \hline Average & $\mathbf{1 5 . 5 1}$ & $\mathbf{1 1 1}$ & $\mathbf{0 . 3 2 7 \mathrm { E } + 0 6}$ \\
\hline Std. Dev. & 0.55 & 398.56 & 0.10 & - & $1.545 \mathrm{E}+04$ \\
\hline
\end{tabular}

Table B-12 Bending Test Results for PC Polymer Blend with 25\% by Weight of Chopped Fibers

\begin{tabular}{|c|c|c|c|c|c|}
\hline Specimen & $\begin{array}{c}\text { Maximum } \\
\text { Load } \\
\text { Ibs. }\end{array}$ & $\begin{array}{c}\text { Maximum } \\
\text { Stress }\end{array}$ & $\begin{array}{c}\text { Deflection @ } \\
\text { Max. Stress }\end{array}$ & $\begin{array}{c}\text { Max. Deflection } \\
\text { Recorded }\end{array}$ & Stiffness, E \\
\hline & 34.90 & 25128.00 & 0.66 & in. & psi \\
\hline BP6-6 & 33.95 & 24444.00 & 0.66 & 0.75 & $1.000 \mathrm{E}+06$ \\
\hline BP6-7 & 35.79 & 25768.80 & 0.72 & 0.79 & $0.991 \mathrm{E}+06$ \\
\hline BP6-8 & 34.85 & 25092.00 & 0.67 & 0.75 & $1.026 \mathrm{E}+06$ \\
\hline BP6-9 & 34.85 & 0.80 & $0.999 \mathrm{E}+06$ \\
\hline BP6-10 & 33.33 & 23997.60 & 0.73 & 0.73 & $0.950 \mathrm{E}+06$ \\
\hline \hline Average & $\mathbf{3 4 . 5 6}$ & $\mathbf{2 4 8 8 6 . 0 8}$ & $\mathbf{0 . 6 9}$ & - & $\mathbf{0 . 9 9 3 E + 0 6}$ \\
\hline Std. Dev. & 0.95 & 682.82 & 0.03 & - & $2.752 \mathrm{E}+04$ \\
\hline
\end{tabular}




\section{APPENDIX-C}

\section{COMPRESSION TEST RESULTS}

Table C-1 Compression Test Results for Virgin ABS

\begin{tabular}{|c|c|c|c|c|c|}
\hline Specimen & $\begin{array}{l}\text { Maximum } \\
\text { Load }\end{array}$ & $\begin{array}{l}\text { Maximum } \\
\text { Stress }\end{array}$ & $\begin{array}{c}\text { Reduction in Length } \\
\text { @ Max. Stress }\end{array}$ & Stiffness, E & Stiffness, E \\
\hline & Ibs. & psi & in. & psi & psi \\
\hline CA1-1 & 1127.47 & 9019.76 & 0.041 & $0.22 \mathrm{E}+06$ & \multirow{5}{*}{$0.34 \mathrm{E}+06$} \\
\hline CA1-2 & 1079.71 & 8637.68 & 0.044 & $0.21 \mathrm{E}+06$ & \\
\hline CA1-3 & 1108.39 & 8867.12 & 0.049 & $0.23 E+06$ & \\
\hline CA1-4 & 1133.32 & 9066.56 & 0.035 & $0.23 E+06$ & \\
\hline CA1-5 & 1154.87 & 9238.96 & 0.039 & $0.24 \mathrm{E}+06$ & \\
\hline "Average & $\overline{1120.75}$ & $\overline{c 8966.02}$ & 0.042 & (0.23E+06 & $0.34 \mathrm{E}+06$ \\
\hline Std. Dev. & 28.30 & 226.43 & 0.01 & $1.21 \mathrm{E}+04$ & $\frac{-}{-6+100}$ \\
\hline
\end{tabular}

Table C-2 Compression Test Results for Virgin ABS with 25\% by Weight of Chopped Fibers

\begin{tabular}{|c|c|c|c|c|c|}
\hline Specimen & $\begin{array}{l}\text { Maximum } \\
\text { Load }\end{array}$ & $\begin{array}{l}\text { Maximum } \\
\text { Stress }\end{array}$ & $\begin{array}{c}\text { Reduction in Length } \\
\text { @ Max. Stress }\end{array}$ & Stiffness, E & Stiffness, E \\
\hline & Ibs. & psi & in. & psi & psi \\
\hline CA2-1 & 1929.22 & 15433.76 & 0.032 & $0.45 \mathrm{E}+06$ & \multirow{8}{*}{$0.91 E+06$} \\
\hline CA2-2 & 1352.89 & 10823.12 & 0.037 & $0.32 E+06$ & \\
\hline CA2-3 & 1413.83 & 11310.64 & 0.034 & $0.33 \mathrm{E}+06$ & \\
\hline CA2-4 & 1526.10 & 12208.80 & 0.034 & $0.34 \mathrm{E}+06$ & \\
\hline CA2-5 & 1908.93 & 15271.44 & 0.035 & $0.44 \mathrm{E}+06$ & \\
\hline CA2-6 & 1734.02 & 13872.16 & 0.031 & $0.40 \mathrm{E}+06$ & \\
\hline CA2-7 & 1812.90 & 14503.20 & 0.033 & $0.44 \mathrm{E}+06$ & \\
\hline CA2-8 & 1457.33 & 11658.64 & 0.038 & $0.33 \mathrm{E}+06$ & \\
\hline Average & 1641.90 & 13135.22 & 0.034 & $0.38 \mathrm{E}+06$ & $0.91 \mathrm{E}+06$ \\
\hline Std. Dev. & 231.33 & 1850.66 & 0.002 & $5.80 \mathrm{E}+04$ & - \\
\hline
\end{tabular}

Table C-3 Compression Test Results for 100\% Recycled ABS

\begin{tabular}{|c|c|c|c|c|c|}
\hline Specimen & $\begin{array}{c}\text { Maximum } \\
\text { Load }\end{array}$ & $\begin{array}{l}\text { Maximum } \\
\text { Stress }\end{array}$ & $\begin{array}{c}\text { Reduction in Length } \\
\text { @ Max. Stress }\end{array}$ & Stiffness, E & Stiffness, E \\
\hline & Ibs. & psi & in. & psi & psi \\
\hline CA3-1 & 1098.21 & 8785.68 & 0.038 & $0.23 \mathrm{E}+06$ & \multirow{5}{*}{$0.42 \mathrm{E}+06$} \\
\hline CA3-2 & 1109.34 & 8874.72 & 0.040 & $0.23 \mathrm{E}+06$ & \\
\hline CA3-3 & 1094.00 & 8752.00 & 0.041 & $0.22 \mathrm{E}+06$ & \\
\hline CA3-4 & 1102.08 & 8816.64 & 0.038 & $0.24 \mathrm{E}+06$ & \\
\hline CA3-5 & 1091.54 & 8732.32 & 0.038 & $0.23 E+06$ & \\
\hline Average & 1099.03 & 8792.27 & 0.039 & $0.23 E+06$ & $0.42 \mathrm{E}+06$ \\
\hline Std. Dev. & 7.03 & 56.24 & 0.001 & $5.31 \mathrm{E}+04$ & - \\
\hline
\end{tabular}


Table C-4 Compression Test Results for $100 \%$ Recycled ABS with $25 \%$ by Weight of Chopped Fibers

\begin{tabular}{|c|c|c|c|c|c|}
\hline Specimen & $\begin{array}{c}\text { Maximum } \\
\text { Load }\end{array}$ & $\begin{array}{c}\text { Maximum } \\
\text { Stress }\end{array}$ & $\begin{array}{c}\text { Reduction in Length } \\
\text { @ Max. Stress }\end{array}$ & Stiffness, E & Stiffness, E \\
\hline & lbs. & psi & in. & psi & psi \\
\hline CA4-1 & 1849.32 & 14794.56 & 0.037 & $0.43 \mathrm{E}+06$ & \multirow{2}{*}{$0.92 \mathrm{E}+06$} \\
\hline CA4-2 & 1710.23 & 13681.84 & 0.032 & $0.39 \mathrm{E}+06$ & \\
\hline CA4-3 & 1681.42 & 13451.36 & 0.034 & $0.39 \mathrm{E}+06$ & \multirow{2}{*}{} \\
\hline CA4-4 & 1988.06 & 15904.48 & 0.034 & $0.46 \mathrm{E}+06$ & \\
\hline CA4-5 & 1984.89 & 15879.12 & 0.034 & $0.45 \mathrm{E}+06$ & \multirow{2}{*}{$\mathbf{0 . 9 2 E + 0 6}$} \\
\hline CA4-6 & 1954.34 & 15634.72 & 0.035 & $0.46 \mathrm{E}+06$ & - \\
\hline \hline Average & $\mathbf{1 8 6 1 . 3 8}$ & $\mathbf{1 4 8 9 1 . 0 1}$ & $\mathbf{0 . 0 3 4}$ & $\mathbf{0 . 4 3 E + 0 6}$ & \\
\hline Std. Dev. & 138.07 & 1104.59 & 0.002 & $3.22 \mathrm{E}+04$ & \\
\hline
\end{tabular}

Table C-5 Compression Test Results for ABS Polymer Blend

\begin{tabular}{|c|c|c|c|c|c|}
\hline Specimen & $\begin{array}{c}\text { Maximum } \\
\text { Load }\end{array}$ & $\begin{array}{c}\text { Maximum } \\
\text { Stress }\end{array}$ & $\begin{array}{c}\text { Reduction in Length } \\
\text { @ Max. Stress }\end{array}$ & Stiffness, E & Stiffness, E \\
\hline & Ibs. & psi & in. & psi & psi \\
\hline CA5-1 & 1124.22 & 8993.76 & 0.038 & $0.22 \mathrm{E}+06$ & \multirow{2}{*}{$0.41 \mathrm{E}+06$} \\
\hline CA5-2 & 1119.07 & 8952.56 & 0.045 & $0.22 \mathrm{E}+06$ & \\
\hline CA5-3 & 1090.27 & 8722.16 & 0.037 & $0.23 \mathrm{E}+06$ & \multirow{2}{*}{} \\
\hline CA5-4 & 1098.35 & 8786.80 & 0.042 & $0.23 \mathrm{E}+06$ & \\
\hline CA5-5 & 1175.85 & 9406.80 & 0.031 & $0.25 \mathrm{E}+06$ & $\mathbf{0 . 4 1 E + 0 6}$ \\
\hline \hline Average & $\mathbf{1 1 2 1 . 5 5}$ & $\mathbf{8 9 7 2 . 4 2}$ & $\mathbf{0 . 0 4}$ & $\mathbf{0 . 2 3 E + 0 6}$ & - \\
\hline Std. Dev. & 33.46 & 267.68 & $\mathbf{0 . 0 0 5}$ & $1.20 \mathrm{E}+04$ & \\
\hline
\end{tabular}

Table C-6 Compression Test Results for ABS Polymer Blend with $25 \%$ by Weight of Chopped Fibers

\begin{tabular}{|c|c|c|c|c|c|}
\hline Specimen & $\begin{array}{l}\text { Maximum } \\
\text { Load }\end{array}$ & $\begin{array}{l}\text { Maximum } \\
\text { Stress }\end{array}$ & $\begin{array}{c}\text { Reduction in Length } \\
@ \text { Max. Stress }\end{array}$ & Stiffness, E & Stiffness, E \\
\hline & Ibs. & psi & in. & psi & psi \\
\hline CA6-1 & 1850.19 & 14801.52 & 0.033 & $0.45 \mathrm{E}+06$ & \multirow{6}{*}{$1.02 E+06$} \\
\hline CA6-2 & 1848.79 & 14790.32 & 0.032 & $0.46 \mathrm{E}+06$ & \\
\hline CA6-3 & 1881.33 & 15050.64 & 0.031 & $0.45 \mathrm{E}+06$ & \\
\hline CA6-4 & 1356.63 & 10853.04 & 0.036 & $0.34 \mathrm{E}+06$ & \\
\hline CA6-5 & 1791.07 & 14328.56 & 0.033 & $0.44 \mathrm{E}+06$ & \\
\hline CA6-6 & 1712.40 & 13699.20 & 0.030 & $0.41 \mathrm{E}+06$ & \\
\hline Average & 1740.07 & 13920.55 & 0.033 & $0.42 E+06$ & $1.02 E+06$ \\
\hline Std. Dev. & 197.13 & 1577.01 & 0.002 & $4.34 \mathrm{E}+04$ & - \\
\hline
\end{tabular}


Table C-7 Compression Test Results for Virgin ABS

\begin{tabular}{|c|c|c|c|c|c|}
\hline Specimen & $\begin{array}{c}\text { Maximum } \\
\text { Load } \\
\text { Ibs. }\end{array}$ & $\begin{array}{c}\text { Maximum } \\
\text { Stress }\end{array}$ & $\begin{array}{c}\text { Reduction in Length } \\
\text { @ Max. Stress }\end{array}$ & $\begin{array}{c}\text { Recorded } \\
\text { Stiffness, E }\end{array}$ & $\begin{array}{c}\text { Corrected } \\
\text { Stiffness, E }\end{array}$ \\
\hline in. & psi & psi \\
\hline CP1-1 & 1294.30 & 10354.40 & 0.050 & $0.19 \mathrm{E}+06$ & $0.36 \mathrm{E}+06$ \\
\hline CP1-2 & 1317.36 & 10538.88 & 0.045 & $0.22 \mathrm{E}+06$ & $0.42 \mathrm{E}+06$ \\
\hline CP1-3 & 1288.79 & 10310.32 & 0.040 & $0.22 \mathrm{E}+06$ & $0.42 \mathrm{E}+06$ \\
\hline CP1-4 & 1301.90 & 10415.20 & 0.039 & $0.21 \mathrm{E}+06$ & $0.41 \mathrm{E}+06$ \\
\hline CP1-5 & 1312.44 & 10499.52 & 0.043 & $0.22 \mathrm{E}+06$ & $0.43 \mathrm{E}+06$ \\
\hline Average & $\mathbf{1 3 0 2 . 9 6}$ & $\mathbf{1 0 4 2 3 . 6 6}$ & $\mathbf{0 . 0 4 3}$ & $\mathbf{0 . 2 1 E + 0 6}$ & $\mathbf{0 . 4 1 E + 0 6}$ \\
\hline Std. Dev. & 11.98 & 95.84 & $\mathbf{0 . 0 0 4}$ & $1.43 \mathrm{E}+04$ & $2.79 \mathrm{E}+04$ \\
\hline
\end{tabular}

Table C-8 Compression Test Results for Virgin ABS with 25\% by Weight of Chopped Fibers

\begin{tabular}{|c|c|c|c|c|c|}
\hline Specimen & $\begin{array}{c}\text { Maximum } \\
\text { Load }\end{array}$ & $\begin{array}{c}\text { Maximum } \\
\text { Stress }\end{array}$ & $\begin{array}{c}\text { Reduction in Length } \\
\text { @ Max. Stress }\end{array}$ & Stiffness, E & Stiffness, E \\
\hline & lbs. & psi & in. & psi & psi \\
\hline CP2-1 & 2654.60 & 21236.80 & 0.043 & $0.38 \mathrm{E}+06$ & $0.75 \mathrm{E}+06$ \\
\hline CP2-2 & 2431.77 & 19454.16 & 0.038 & $0.41 \mathrm{E}+06$ & $0.80 \mathrm{E}+06$ \\
\hline CP2-3 & 2564.28 & 20514.24 & 0.037 & $0.41 \mathrm{E}+06$ & $0.80 \mathrm{E}+06$ \\
\hline CP2-4 & 2536.19 & 20289.52 & 0.038 & $0.42 \mathrm{E}+06$ & $0.82 \mathrm{E}+06$ \\
\hline CP2-5 & 2580.91 & 20647.28 & 0.036 & $0.42 \mathrm{E}+06$ & $0.82 \mathrm{E}+06$ \\
\hline CP2-6 & 2481.87 & 19854.96 & 0.045 & $0.39 \mathrm{E}+06$ & $0.76 \mathrm{E}+06$ \\
\hline \hline Average & $\mathbf{2 5 4 1 . 6 0}$ & $\mathbf{2 0 3 3 2 . 8 3}$ & $\mathbf{0 . 0 4 0}$ & $\mathbf{0 . 4 1 E + 0 6}$ & $\mathbf{0 . 8 0 E}+\mathbf{0 6}$ \\
\hline Std. Dev. & 78.09 & 624.70 & 0.004 & $1.58 \mathrm{E}+04$ & $3.07 \mathrm{E}+04$ \\
\hline
\end{tabular}

Table C-9 Compression Test Results for $100 \%$ Recycled ABS

\begin{tabular}{|c|c|c|c|c|c|}
\hline Specimen & $\begin{array}{c}\text { Maximum } \\
\text { Load } \\
\text { Ibs. }\end{array}$ & $\begin{array}{c}\text { Maximum } \\
\text { Stress }\end{array}$ & $\begin{array}{c}\text { Reduction in Length } \\
\text { @ Max. }\end{array}$ & Stiffness, E & Stiffness, E \\
\hline & 1302.14 & 10471.12 & 0.043 & psi & psi \\
\hline CP3-1 & 1294.06 & 10352.48 & 0.044 & $0.19 \mathrm{E}+06$ & $0.37 \mathrm{E}+06$ \\
\hline CP3-2 & 129.06 & $0.20 \mathrm{E}+06$ & $0.38 \mathrm{E}+06$ \\
\hline CP3-3 & 1290.90 & 10327.20 & 0.045 & $0.20 \mathrm{E}+06$ & $0.40 \mathrm{E}+06$ \\
\hline CP3-4 & 1264.21 & 10113.68 & 0.051 & $0.18 \mathrm{E}+06$ & $0.34 \mathrm{E}+06$ \\
\hline CP3-5 & 1276.97 & 10215.76 & 0.039 & $0.21 \mathrm{E}+06$ & $0.42 \mathrm{E}+06$ \\
\hline CP3-6 & 1305.18 & 10441.44 & 0.039 & $0.21 \mathrm{E}+06$ & $0.42 \mathrm{E}+06$ \\
\hline \hline Average & $\mathbf{1 2 8 8 . 9 1}$ & $\mathbf{1 0 3 1 1 . 2 8}$ & $\mathbf{0 . 0 4 4}$ & $\mathbf{0 . 2 0 E}+\mathbf{0 6}$ & $\mathbf{0 . 3 9 E}+\mathbf{0 6}$ \\
\hline Std. Dev. & 15.64 & 125.11 & 0.004 & $1.49 \mathrm{E}+05$ & $2.90 \mathrm{E}+05$ \\
\hline
\end{tabular}


Table C-10 Compression Test Results for $100 \%$ Recycled ABS with $25 \%$ by Weight of Chopped Fibers

\begin{tabular}{|c|c|c|c|c|c|}
\hline Specimen & $\begin{array}{c}\text { Maximum } \\
\text { Load }\end{array}$ & $\begin{array}{c}\text { Maximum } \\
\text { Stress }\end{array}$ & $\begin{array}{c}\text { Reduction in Length } \\
\text { @ Max. Stress }\end{array}$ & Stiffness, E & Stiffness, E \\
\hline & lbs. & psi & in. & psi & psi \\
\hline CP4-1 & 2643.83 & 21150.64 & 0.044 & $0.42 \mathrm{E}+06$ & $0.82 \mathrm{E}+06$ \\
\hline CP4-2 & 2533.38 & 20267.04 & 0.034 & $0.42 \mathrm{E}+06$ & $0.82 \mathrm{E}+06$ \\
\hline CP4-3 & 2520.74 & 20165.92 & 0.033 & $0.43 \mathrm{E}+06$ & $0.84 \mathrm{E}+06$ \\
\hline CP4-4 & 2651.26 & 21210.08 & 0.038 & $0.42 \mathrm{E}+06$ & $0.83 \mathrm{E}+06$ \\
\hline CP4-5 & 2637.21 & 21097.68 & 0.038 & $0.44 \mathrm{E}+06$ & $0.85 \mathrm{E}+06$ \\
\hline CP4-6 & 2574.00 & 20592.00 & 0.033 & $0.44 \mathrm{E}+06$ & $0.86 \mathrm{E}+06$ \\
\hline \hline Average & $\mathbf{2 5 9 3 . 4 0}$ & $\mathbf{2 0 7 4 7 . 2 3}$ & $\mathbf{0 . 0 3 7}$ & $\mathbf{0 . 4 3 E + 0 6}$ & $\mathbf{0 . 8 4 E + 0 6}$ \\
\hline Std. Dev. & 58.43 & 467.42 & 0.004 & $0.76 \mathrm{E}+04$ & $1.47 \mathrm{E}+04$ \\
\hline
\end{tabular}

Table C-11 Compression Test Results for ABS Polymer Blend

\begin{tabular}{|c|c|c|c|c|c|}
\hline Specimen & $\begin{array}{c}\text { Maximum } \\
\text { Load }\end{array}$ & $\begin{array}{c}\text { Maximum } \\
\text { Stress }\end{array}$ & $\begin{array}{c}\text { Reduction in Length } \\
\text { @ Max. Stress }\end{array}$ & Stiffness, E & Stiffness, E \\
\hline & Ibs. & psi & in. & psi & psi \\
\hline CP5-1 & 1314.55 & 10516.40 & 0.045 & $0.20 \mathrm{E}+06$ & $0.40 \mathrm{E}+06$ \\
\hline CP5-2 & 1324.74 & 10597.92 & 0.048 & $0.21 \mathrm{E}+06$ & $0.42 \mathrm{E}+06$ \\
\hline CP5-3 & 1310.23 & 10481.84 & 0.043 & $0.21 \mathrm{E}+06$ & $0.41 \mathrm{E}+06$ \\
\hline CP5-4 & 1317.95 & 10543.60 & 0.046 & $0.21 \mathrm{E}+06$ & $0.41 \mathrm{E}+06$ \\
\hline CP5-5 & 1309.99 & 10479.92 & 0.040 & $0.21 \mathrm{E}+06$ & $0.42 \mathrm{E}+06$ \\
\hline \hline Average & $\mathbf{1 3 1 5 . 4 9}$ & $\mathbf{1 0 5 2 3 . 9 4}$ & $\mathbf{0 . 0 4 4}$ & $\mathbf{0 . 2 1 E + 0 6}$ & $\mathbf{0 . 4 1 E + 0 6}$ \\
\hline Std. Dev. & 6.13 & 49.06 & $\mathbf{0 . 0 0 3}$ & $0.44 \mathrm{E}+04$ & $0.85 \mathrm{E}+04$ \\
\hline
\end{tabular}

Table C-12 Compression Test Results for ABS Polymer Blend with 25\% by Weight of Chopped Fibers

\begin{tabular}{|c|c|c|c|c|c|}
\hline Specimen & $\begin{array}{c}\text { Maximum } \\
\text { Load }\end{array}$ & $\begin{array}{c}\text { Maximum } \\
\text { Stress }\end{array}$ & $\begin{array}{c}\text { Reduction in Length } \\
\text { @ Max. Stress }\end{array}$ & Stiffness, E & Stiffness, $\mathbf{E}$ \\
\hline & lbs. & psi & in. & psi & psi \\
\hline CP6-1 & 2580.67 & 20645.36 & 0.039 & $0.41 \mathrm{E}+06$ & $0.80 \mathrm{E}+06$ \\
\hline CP6-2 & 2642.83 & 21142.64 & 0.037 & $0.44 \mathrm{E}+06$ & $0.87 \mathrm{E}+06$ \\
\hline CP6-3 & 2624.49 & 20995.92 & 0.037 & $0.41 \mathrm{E}+06$ & $0.81 \mathrm{E}+06$ \\
\hline CP6-4 & 2722.51 & 21780.08 & 0.040 & $0.44 \mathrm{E}+06$ & $0.86 \mathrm{E}+06$ \\
\hline CP6-5 & 2642.54 & 21140.32 & 0.039 & $0.43 \mathrm{E}+06$ & $0.83 \mathrm{E}+06$ \\
\hline CP6-6 & 2540.35 & 20322.80 & 0.038 & $0.41 \mathrm{E}+06$ & $0.80 \mathrm{E}+06$ \\
\hline CP6-7 & 2730.23 & 21841.84 & 0.038 & $0.44 \mathrm{E}+06$ & $0.86 \mathrm{E}+06$ \\
\hline \hline Average & $\mathbf{2 6 4 0 . 5 2}$ & $\mathbf{2 1 1 2 4 . 1 4}$ & $\mathbf{0 . 0 3 8}$ & $\mathbf{0 . 4 3 E + 0 6}$ & $\mathbf{0 . 8 3 E + 0 6}$ \\
\hline Std. Dev. & 69.10 & 552.84 & 0.001 & $1.56 \mathrm{E}+04$ & $3.04 \mathrm{E}+04$ \\
\hline
\end{tabular}




\section{APPENDIX-D}

\section{IMPACT TEST RESULTS}

Table D-1 Impact Test Results for Virgin ABS

\begin{tabular}{|c|c|c|c|c|}
\hline Specimen & $\begin{array}{c}\text { Indicated } \\
\text { Impact Strength }\end{array}$ & $\begin{array}{c}\text { Corrected } \\
\text { Impact Strength }\end{array}$ & Impact Strength & Failure Type \\
\hline & $\mathrm{ft}-l \mathrm{bs}_{\mathrm{f}}$ & $\mathrm{ft}-\mathrm{lbs}_{\mathrm{f}}$ & $\mathrm{ft}_{\mathrm{f}} \mathrm{lbs} \mathrm{f}_{\mathrm{f}} / \mathrm{in}$ & \\
\hline $\mathrm{IA} 1-2$ & 0.46 & 0.42 & 3.36 & $\mathrm{H}$ \\
\hline $\mathrm{IA} 1-3$ & 0.48 & 0.44 & 3.52 & $\mathrm{H}$ \\
\hline $\mathrm{IA} 1-4$ & 0.46 & 0.42 & 3.36 & $\mathrm{H}$ \\
\hline $\mathrm{IA} 1-5$ & 0.49 & 0.45 & 3.60 & $\mathrm{H}$ \\
\hline IA1-6 & 0.49 & 0.45 & 3.60 & $\mathrm{H}$ \\
\hline \hline Average & $\mathbf{0 . 4 8}$ & $\mathbf{0 . 4 4}$ & $\mathbf{3 . 4 9}$ & - \\
\hline Std. Dev. & 0.02 & 0.02 & 0.12 & - \\
\hline
\end{tabular}

Table D-2 Impact Test Results for Virgin ABS with $25 \%$ by Weight of Chopped Fibers

\begin{tabular}{|c|c|c|c|c|}
\hline Specimen & $\begin{array}{c}\text { Indicated } \\
\text { Impact Strength }\end{array}$ & $\begin{array}{c}\text { Corrected } \\
\text { Impact Strength }\end{array}$ & Impact Strength & Failure Type \\
\hline & $\mathrm{ft}-l \mathrm{bs}_{\mathrm{f}}$ & $\mathrm{ft}-l \mathrm{bS}_{\mathrm{f}}$ & $\mathrm{ft}-\mathrm{lbs} / \mathrm{in}$ & \\
\hline $\mathrm{IA} 2-2$ & 0.25 & 0.20 & 1.60 & $\mathrm{C}$ \\
\hline $\mathrm{IA} 2-3$ & 0.25 & 0.20 & 1.60 & $\mathrm{C}$ \\
\hline $\mathrm{IA} 2-4$ & 0.25 & 0.20 & 1.60 & $\mathrm{C}$ \\
\hline $\mathrm{IA} 2-5$ & 0.24 & 0.19 & 1.52 & $\mathrm{C}$ \\
\hline IA2-6 & 0.25 & 0.20 & 1.60 & $\mathrm{C}$ \\
\hline \hline Average & $\mathbf{0 . 2 5}$ & $\mathbf{0 . 2 0}$ & $\mathbf{1 . 5 8}$ & - \\
\hline Std. Dev. & 0.00 & 0.00 & 0.04 & - \\
\hline
\end{tabular}

Table D-3 Impact Test Results for 100\% Recycled ABS

\begin{tabular}{|c|c|c|c|c|}
\hline Specimen & $\begin{array}{c}\text { Indicated } \\
\text { Impact Strength }\end{array}$ & $\begin{array}{c}\text { Corrected } \\
\text { Impact Strength }\end{array}$ & Impact Strength & Failure Type \\
\hline & ${\mathrm{ft}-l \mathrm{bS}_{\mathrm{f}}}^{\mathrm{ft}-\mathrm{bs}_{\mathrm{f}}}$ & $\mathrm{ft}-\mathrm{Ibs}_{\mathrm{f}} / \mathrm{in}$ & \\
\hline IA3-2 & 0.32 & 0.28 & 2.24 & $\mathrm{H}$ \\
\hline IA3-3 & 0.30 & 0.26 & 2.04 & $\mathrm{H}$ \\
\hline IA3-4 & 0.30 & 0.26 & 2.08 & $\mathrm{H}$ \\
\hline IA3-5 & 0.32 & 0.28 & 2.24 & $\mathrm{H}$ \\
\hline IA3-6 & 0.32 & 0.28 & 2.24 & - \\
\hline Average & $\mathbf{0 . 3 1}$ & $\mathbf{0 . 2 7}$ & $\mathbf{2 . 1 7}$ & - \\
\hline Std. Dev. & 0.01 & 0.01 & 0.10 & \\
\hline
\end{tabular}


Table D-4 Impact Test Results for 100\% Recycled ABS with 25\% by Weight of Chopped Fibers

\begin{tabular}{|c|c|c|c|c|}
\hline Specimen & $\begin{array}{c}\text { Indicated } \\
\text { Impact Strength }\end{array}$ & $\begin{array}{c}\text { Corrected } \\
\text { Impact Strength }\end{array}$ & Impact Strength & Failure Type \\
\hline & $\mathrm{ft}-l \mathrm{bs}_{\mathrm{f}}$ & ${\mathrm{ft}-l \mathrm{bs}_{\mathrm{f}}}$ & $\mathrm{ft}-\mathrm{lbs} \mathrm{s}_{\mathrm{f}} / \mathrm{in}$ & \\
\hline $\mathrm{IA} 4-2$ & 0.17 & 0.12 & 0.96 & $\mathrm{C}$ \\
\hline $\mathrm{IA} 4-3$ & 0.17 & 0.12 & 0.96 & $\mathrm{C}$ \\
\hline $\mathrm{IA} 4-4$ & 0.18 & 0.13 & 1.06 & $\mathrm{C}$ \\
\hline IA4-5 & 0.16 & 0.11 & 0.88 & $\mathrm{C}$ \\
\hline IA4-6 & 0.17 & 0.12 & 0.96 & $\mathrm{C}$ \\
\hline \hline Average & $\mathbf{0 . 1 7}$ & $\mathbf{0 . 1 2}$ & $\mathbf{0 . 9 6}$ & - \\
\hline Std. Dev. & 0.01 & 0.01 & 0.06 & - \\
\hline
\end{tabular}

Table D-5 Impact Test Results for ABS Polymer Blend

\begin{tabular}{|c|c|c|c|c|}
\hline Specimen & $\begin{array}{c}\text { Indicated } \\
\text { Impact Strength }\end{array}$ & $\begin{array}{c}\text { Corrected } \\
\text { Impact Strength }\end{array}$ & Impact Strength & Failure Type \\
\hline & $\mathrm{ft}-l \mathrm{bs}_{\mathrm{f}}$ & $\mathrm{ft}-\mathrm{lbs}_{\mathrm{f}}$ & $\mathrm{ft}_{\mathrm{fbs}} / \mathrm{in}$ & \\
\hline IA5-2 & 0.28 & 0.23 & 1.84 & $\mathrm{H}$ \\
\hline IA5-3 & 0.30 & 0.26 & 2.08 & $\mathrm{C}$ \\
\hline IA5-4 & 0.36 & 0.32 & 2.56 & $\mathrm{C}$ \\
\hline IA5-5 & 0.36 & 0.32 & 2.56 & $\mathrm{H}$ \\
\hline IA5-6 & 0.40 & 0.36 & 2.85 & - \\
\hline \hline Average & $\mathbf{0 . 3 4}$ & $\mathbf{0 . 3 0}$ & $\mathbf{2 . 3 8}$ & - \\
\hline Std. Dev. & 0.05 & 0.05 & 0.41 & - \\
\hline
\end{tabular}

Table D-6 Impact Test Results for ABS Polymer Blend with 25\% by Weight of Chopped Fibers

\begin{tabular}{|c|c|c|c|c|}
\hline Specimen & $\begin{array}{c}\text { Indicated } \\
\text { Impact Strength }\end{array}$ & $\begin{array}{c}\text { Corrected } \\
\text { Impact Strength }\end{array}$ & Impact Strength & Failure Type \\
\hline & $\mathrm{ft}-\mathrm{Ibs}_{\mathrm{f}}$ & $\mathrm{ft}-\mathrm{Ibs}_{\mathrm{f}}$ & $\mathrm{ft}-\mathrm{lbs} / / \mathrm{in}$ & \\
\hline IA6-2 & 0.19 & 0.14 & 1.12 & C \\
\hline IA6-3 & 0.20 & 0.15 & 1.20 & $C$ \\
\hline IA6-4 & 0.20 & 0.15 & 1.20 & $\mathrm{C}$ \\
\hline IA6-5 & 0.20 & 0.15 & 1.20 & C \\
\hline IA6-6 & 0.21 & 0.16 & 1.28 & C \\
\hline Average & 0.20 & 0.15 & 1.20 & - \\
\hline Std. Dev. & 0.01 & 0.01 & 0.06 & - \\
\hline
\end{tabular}


Table D-7 Impact Test Results for Virgin PC

\begin{tabular}{|c|c|c|c|c|}
\hline Specimen & $\begin{array}{c}\text { Indicated } \\
\text { Impact Strength }\end{array}$ & $\begin{array}{c}\text { Corrected } \\
\text { Impact Strength }\end{array}$ & Impact Strength & Failure Type \\
\hline & $\mathrm{ft}-\mathrm{lbs}_{\mathrm{f}}$ & $\mathrm{ft}-\mathrm{Ibs}_{\mathrm{f}}$ & $\mathrm{ft}-\mathrm{lbs} / \mathrm{in}$ & \\
\hline IP1-2 & 1.82 & 1.80 & 14.40 & $P$ \\
\hline IP1-3 & 1.74 & 1.72 & 13.76 & $P$ \\
\hline IP1-4 & 1.81 & 1.79 & 14.32 & $\mathrm{P}$ \\
\hline IP1-5 & 1.79 & 1.77 & 14.16 & $P$ \\
\hline IP1-6 & 1.75 & 1.73 & 13.84 & $P$ \\
\hline IP1-7 & 1.82 & 1.80 & 14.40 & $\mathrm{P}$ \\
\hline Average & 1.79 & 1.77 & 14.15 & - \\
\hline Std. Dev. & 0.04 & 0.35 & 0.28 & - \\
\hline
\end{tabular}

Table D-8 Impact Test Results for Virgin PC with 25\% by Weight of Chopped Fibers

\begin{tabular}{|c|c|c|c|c|}
\hline Specimen & $\begin{array}{c}\text { Indicated } \\
\text { Impact Strength }\end{array}$ & $\begin{array}{c}\text { Corrected } \\
\text { Impact Strength }\end{array}$ & Impact Strength & Failure Type \\
\hline & $\mathrm{ft}^{-\mathrm{lbs}_{\mathrm{f}}}$ & $\mathrm{ft}_{\mathrm{fbs}}$ & $\mathrm{ft}_{\mathrm{f}}-\mathrm{lbs}_{\mathrm{f}} / \mathrm{in}$ & \\
\hline $\mathrm{IP2} 2$ & 0.41 & 0.37 & 2.96 & $\mathrm{C}$ \\
\hline $\mathrm{IP2}-3$ & 0.42 & 0.38 & 3.04 & $\mathrm{C}$ \\
\hline $\mathrm{IP2}-4$ & 0.42 & 0.38 & 3.04 & $\mathrm{C}$ \\
\hline $\mathrm{IP2}-5$ & 0.41 & 0.37 & 2.96 & $\mathrm{C}$ \\
\hline IP2-6 & 0.42 & 0.38 & 3.04 & $\mathrm{H}$ \\
\hline \hline Average & $\mathbf{0 . 4 2}$ & $\mathbf{0 . 3 8}$ & $\mathbf{3 . 0 1}$ & - \\
\hline Std. Dev. & 0.01 & 0.01 & 0.04 & - \\
\hline
\end{tabular}

Table D-9 Impact Test Results for 100\% Recycled PC

\begin{tabular}{|c|c|c|c|c|}
\hline Specimen & $\begin{array}{c}\text { Indicated } \\
\text { Impact Strength }\end{array}$ & $\begin{array}{c}\text { Corrected } \\
\text { Impact Strength }\end{array}$ & Impact Strength & Failure Type \\
\hline & $\mathrm{ft}^{-l \mathrm{bS}_{\mathrm{f}}}$ & $\mathrm{ft}-\mathrm{lbs}_{\mathrm{f}}$ & $\mathrm{ft}-\mathrm{Ibs}_{\uparrow} / \mathrm{in}$ & \\
\hline IP3-2 & 1.70 & 1.68 & 13.44 & $P$ \\
\hline IP3-3 & 1.70 & 1.68 & 13.44 & $P$ \\
\hline IP3-4 & 1.57 & 1.54 & 12.32 & $\mathrm{P}$ \\
\hline IP3-5 & 1.79 & 1.77 & 14.16 & $P$ \\
\hline IP3-6 & 1.74 & 1.72 & 13.76 & $P$ \\
\hline IP3-7 & 1.75 & 1.73 & 13.84 & $\mathrm{P}$ \\
\hline IP3-8 & 1.74 & 1.72 & 13.76 & $\mathrm{P}$ \\
\hline Average & 1.71 & 1.69 & 13.53 & 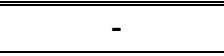 \\
\hline Std. Dev. & 0.07 & 0.07 & 0.59 & - \\
\hline
\end{tabular}


Table D-10 Impact Test Results for $100 \%$ Recycled PC with $25 \%$ by Weight of Chopped Fibers

\begin{tabular}{|c|c|c|c|c|}
\hline Specimen & $\begin{array}{c}\text { Indicated } \\
\text { Impact Strength }\end{array}$ & $\begin{array}{c}\text { Corrected } \\
\text { Impact Strength }\end{array}$ & Impact Strength & Failure Type \\
\hline & $\mathrm{ft}-l \mathrm{bs}_{\mathrm{f}}$ & ${\mathrm{ft}-l \mathrm{bs}_{\mathrm{f}}}$ & $\mathrm{ft}-\mathrm{lbs} / \mathrm{in}$ & \\
\hline $\mathrm{IP} 4-2$ & 0.26 & 0.22 & 1.76 & $\mathrm{C}$ \\
\hline $\mathrm{IP} 4-3$ & 0.29 & 0.25 & 2.00 & $\mathrm{C}$ \\
\hline $\mathrm{IP} 4-4$ & 0.26 & 0.22 & 1.76 & $\mathrm{C}$ \\
\hline $\mathrm{IP} 4-5$ & 0.25 & 0.21 & 1.68 & $\mathrm{C}$ \\
\hline IP4-6 & 0.27 & 0.23 & 1.84 & $\mathrm{C}$ \\
\hline \hline Average & $\mathbf{0 . 2 7}$ & $\mathbf{0 . 2 3}$ & $\mathbf{1 . 8 1}$ & - \\
\hline Std. Dev. & 0.02 & 0.02 & 0.12 & - \\
\hline
\end{tabular}

Table D-11 Impact Test Results for PC Polymer Blend

\begin{tabular}{|c|c|c|c|c|}
\hline Specimen & $\begin{array}{c}\text { Indicated } \\
\text { Impact Strength }\end{array}$ & $\begin{array}{c}\text { Corrected } \\
\text { Impact Strength }\end{array}$ & Impact Strength & Failure Type \\
\hline & $\mathrm{ft}^{-\mathrm{lbs}_{\mathrm{f}}}$ & $\mathrm{ft}_{\mathrm{lbs}}$ & $\mathrm{ft}-\mathrm{lbs}_{\mathrm{f}} / \mathrm{in}$ & \\
\hline IP5-2 & 1.87 & 1.85 & 14.80 & $\mathrm{P}$ \\
\hline IP5-3 & 1.87 & 1.85 & 14.80 & $\mathrm{P}$ \\
\hline IP5-4 & 1.86 & 1.84 & 14.72 & $\mathrm{P}$ \\
\hline IP5-5 & 1.87 & 1.85 & 14.80 & $\mathrm{P}$ \\
\hline IP5-6 & 1.88 & 1.86 & 14.88 & - \\
\hline \hline Average & $\mathbf{1 . 8 7}$ & $\mathbf{1 . 8 5}$ & $\mathbf{1 4 . 8 0}$ & - \\
\hline Std. Dev. & 0.01 & 0.01 & 0.06 & \\
\hline
\end{tabular}

Table D-12 Impact Test Results for PC Polymer Blend with 25\% by Weight of Chopped Fibers

\begin{tabular}{|c|c|c|c|c|}
\hline Specimen & $\begin{array}{c}\text { Indicated } \\
\text { Impact Strength }\end{array}$ & $\begin{array}{c}\text { Corrected } \\
\text { Impact Strength }\end{array}$ & Impact Strength & Failure Type \\
\hline & $\mathrm{ft}-\mathrm{Ibs}_{\mathrm{f}}$ & $\mathrm{ft}-\mathrm{Ibs}_{\mathrm{f}}$ & $\mathrm{ft}-\mathrm{lbs} / / \mathrm{in}$ & \\
\hline IP6-2 & 0.37 & 0.33 & 2.64 & C \\
\hline IP6-3 & 0.36 & 0.32 & 2.56 & $C$ \\
\hline IP6-4 & 0.37 & 0.33 & 2.64 & $\mathrm{C}$ \\
\hline IP6-5 & 0.38 & 0.34 & 2.72 & C \\
\hline IP6-6 & 0.39 & 0.35 & 2.80 & C \\
\hline Average & 0.37 & 0.33 & 2.67 & - \\
\hline Std. Dev. & 0.01 & 0.01 & 0.09 & - \\
\hline
\end{tabular}




\section{APPENDIX-E}

\section{HARDNESS TEST RESULTS}

Table E-1 Hardness Test Results for Virgin ABS

\begin{tabular}{|c|c|c|}
\hline Specimen & Without Weight & With 626g Weight \\
\hline & & \\
\hline HA1-1 & 11.0 & 25.5 \\
\hline HA1-2 & 11.0 & 25.0 \\
\hline HA1-3 & 10.7 & 26.0 \\
\hline HA1-4 & 10.6 & 26.0 \\
\hline HA1-5 & 11.0 & 25.8 \\
\hline HA1-6 & 10.9 & 26.0 \\
\hline HA1-7 & 11.0 & 25.8 \\
\hline HA1-8 & 10.9 & 25.8 \\
\hline Average & $\mathbf{1 0 . 9}$ & $\mathbf{2 5 . 7}$ \\
\hline Std. Dev. & 0.2 & 0.3 \\
\hline
\end{tabular}

Table E-2 Hardness Test Results for Virgin ABS with $25 \%$ by Weight of Chopped Fibers

\begin{tabular}{|c|c|c|}
\hline Specimen & Without Weight & With 626g Weight \\
\hline & & \\
\hline HA2-1 & 11.3 & 25.9 \\
\hline HA2-2 & 11.3 & 25.8 \\
\hline HA2-3 & 11.3 & 25.6 \\
\hline HA2-4 & 11.2 & 25.8 \\
\hline HA2-5 & 11.2 & 25.8 \\
\hline HA2-6 & 11.2 & 25.9 \\
\hline HA2-7 & 11.2 & 25.8 \\
\hline HA2-8 & 11.3 & 25.7 \\
\hline Average & $\mathbf{1 1 . 3}$ & $\mathbf{2 5 . 8}$ \\
\hline Std. Dev. & 0.1 & 0.1 \\
\hline
\end{tabular}


Table E-3 Hardness Test Results for $100 \%$ Recycled ABS

\begin{tabular}{|c|c|c|}
\hline Specimen & Without Weight & With 626g Weight \\
\hline & & \\
\hline HA3-1 & 11.2 & 25.6 \\
\hline HA3-2 & 11.1 & 25.6 \\
\hline HA3-3 & 11.1 & 25.8 \\
\hline HA3-4 & 10.9 & 25.5 \\
\hline HA3-5 & 11.1 & 25.5 \\
\hline HA3-6 & 11.2 & 25.5 \\
\hline HA3-7 & 11.2 & 25.4 \\
\hline HA3-8 & 11.2 & 25.5 \\
\hline \hline Average & $\mathbf{1 1 . 1}$ & $\mathbf{2 5 . 6}$ \\
\hline Std. Dev. & 0.1 & 0.1 \\
\hline
\end{tabular}

Table E-4 Hardness Test Results for $100 \%$ Recycled ABS with $25 \%$ by Weight of Chopped Fibers

\begin{tabular}{|c|c|c|}
\hline Specimen & Without Weight & With 626g Weight \\
\hline & & \\
\hline HA4-1 & 11.2 & 25.8 \\
\hline HA4-2 & 11.1 & 25.7 \\
\hline HA4-3 & 11.2 & 25.7 \\
\hline HA4-4 & 11.2 & 25.7 \\
\hline HA4-5 & 11.2 & 25.4 \\
\hline HA4-6 & 11.2 & 25.8 \\
\hline HA4-7 & 11.1 & 25.6 \\
\hline HA4-8 & 11.2 & 25.7 \\
\hline Average & $\mathbf{1 1 . 2}$ & $\mathbf{2 5 . 7}$ \\
\hline Std. Dev. & 0.0 & 0.1 \\
\hline
\end{tabular}

Table E-5 Hardness Test Results for ABS Polymer Blend

\begin{tabular}{|c|c|c|}
\hline Specimen & Without Weight & With 626g Weight \\
\hline & & \\
\hline HA5-1 & 11.3 & 25.7 \\
\hline HA5-2 & 11.0 & 25.9 \\
\hline HA5-3 & 11.3 & 25.7 \\
\hline HA5-4 & 11.3 & 26.0 \\
\hline HA5-5 & 11.2 & 26.1 \\
\hline HA5-6 & 11.3 & 25.8 \\
\hline HA5-7 & 11.3 & 25.8 \\
\hline HA5-8 & 11.0 & 25.8 \\
\hline \hline Average & $\mathbf{1 1 . 2}$ & $\mathbf{2 5 . 9}$ \\
\hline Std. Dev. & 0.1 & 0.1 \\
\hline
\end{tabular}


Table E-6 Hardness Test Results for ABS Polymer Blend with 25\% by Weight of Chopped Fibers

\begin{tabular}{|c|c|c|}
\hline Specimen & Without Weight & With 626g Weight \\
\hline & & \\
\hline HA6-1 & 11.2 & 25.9 \\
\hline HA6-2 & 11.2 & 25.9 \\
\hline HA6-3 & 11.1 & 25.8 \\
\hline HA6-4 & 11.1 & 25.9 \\
\hline HA6-5 & 11.3 & 25.8 \\
\hline HA6-6 & 11.2 & 25.7 \\
\hline HA6-7 & 11.2 & 25.8 \\
\hline HA6-8 & 11.1 & 25.8 \\
\hline Average & $\mathbf{1 1 . 2}$ & $\mathbf{2 5 . 8}$ \\
\hline Std. Dev. & 0.1 & 0.1 \\
\hline
\end{tabular}

Table E-7 Hardness Test Results for Virgin PC

\begin{tabular}{|c|c|c|}
\hline Specimen & Without Weight & With 626g Weight \\
\hline & & \\
\hline HP1-1 & 10.6 & 25.3 \\
\hline HP1-2 & 10.6 & 25.3 \\
\hline HP1-3 & 10.6 & 25.3 \\
\hline HP1-4 & 10.6 & 25.1 \\
\hline HP1-5 & 10.6 & 25.3 \\
\hline HP1-6 & 10.7 & 25.1 \\
\hline HP1-7 & 10.6 & 25.3 \\
\hline HP1-8 & 10.6 & 25.3 \\
\hline \hline Average & $\mathbf{1 0 . 6}$ & $\mathbf{2 5 . 3}$ \\
\hline Std. Dev. & 0.0 & 0.1 \\
\hline
\end{tabular}

Table E-8 Hardness Test Results for Virgin PC with $25 \%$ by Weight of Chopped Fibers

\begin{tabular}{|c|c|c|}
\hline Specimen & Without Weight & With 626g Weight \\
\hline & & \\
\hline HP2-1 & 10.7 & 25.2 \\
\hline HP2-2 & 10.7 & 25.6 \\
\hline HP2-3 & 10.6 & 25.5 \\
\hline HP2-4 & 10.7 & 25.2 \\
\hline HP2-5 & 10.6 & 25.2 \\
\hline HP2-6 & 10.7 & 25.4 \\
\hline HP2-7 & 10.7 & 25.3 \\
\hline HP2-8 & 10.6 & 25.2 \\
\hline \hline Average & $\mathbf{1 0 . 7}$ & $\mathbf{2 5 . 3}$ \\
\hline Std. Dev. & 0.1 & 0.2 \\
\hline
\end{tabular}


Table E-9 Hardness Test Results for 100\% Recycled PC

\begin{tabular}{|c|c|c|}
\hline Specimen & Without Weight & With 626g Weight \\
\hline & & \\
\hline HP3-1 & 10.7 & 25.4 \\
\hline HP3-2 & 10.8 & 25.5 \\
\hline HP3-3 & 10.6 & 25.5 \\
\hline HP3-4 & 10.7 & 25.3 \\
\hline HP3-5 & 10.6 & 25.4 \\
\hline HP3-6 & 10.6 & 25.4 \\
\hline HP3-7 & 10.5 & 25.3 \\
\hline HP3-8 & 10.6 & 25.5 \\
\hline \hline Average & $\mathbf{1 0 . 6}$ & $\mathbf{2 5 . 4}$ \\
\hline Std. Dev. & 0.1 & 0.1 \\
\hline
\end{tabular}

Table E-10 Hardness Test Results for 100\% Recycled PC with 25\% by Weight of Chopped Fibers

\begin{tabular}{|c|c|c|}
\hline Specimen & Without Weight & With 626g Weight \\
\hline & & \\
\hline HP4-1 & 10.7 & 25.3 \\
\hline HP4-2 & 10.6 & 25.4 \\
\hline HP4-3 & 10.6 & 25.4 \\
\hline HP4-4 & 10.7 & 25.5 \\
\hline HP4-5 & 10.8 & 25.2 \\
\hline HP4-6 & 10.7 & 25.3 \\
\hline HP4-7 & 10.7 & 25.3 \\
\hline HP4-8 & 10.8 & 25.2 \\
\hline Average & $\mathbf{1 0 . 7}$ & $\mathbf{2 5 . 3}$ \\
\hline Std. Dev. & 0.1 & 0.1 \\
\hline
\end{tabular}

Table E-11 Hardness Test Results for PC Polymer Blend

\begin{tabular}{|c|c|c|}
\hline Specimen & Without Weight & With 626g Weight \\
\hline & & \\
\hline HP5-1 & 10.8 & 25.6 \\
\hline HP5-2 & 10.6 & 25.4 \\
\hline HP5-3 & 10.7 & 25.5 \\
\hline HP5-4 & 10.8 & 25.6 \\
\hline HP5-5 & 10.6 & 25.4 \\
\hline HP5-6 & 10.7 & 25.4 \\
\hline HP5-7 & 10.8 & 25.5 \\
\hline HP5-8 & 10.7 & 25.6 \\
\hline Average & $\mathbf{1 0 . 7}$ & $\mathbf{2 5 . 5}$ \\
\hline Std. Dev. & 0.1 & 0.1 \\
\hline
\end{tabular}


Table E-12 Hardness Test Results for PC Polymer Blend with 25\% by Weight of Chopped Fibers

\begin{tabular}{|c|c|c|}
\hline Specimen & Without Weight & With 626g Weight \\
\hline & & \\
\hline HP6-1 & 10.7 & 25.4 \\
\hline HP6-2 & 10.6 & 25.4 \\
\hline HP6-3 & 10.8 & 25.6 \\
\hline HP6-4 & 10.7 & 25.3 \\
\hline HP6-5 & 10.8 & 25.4 \\
\hline HP6-6 & 10.8 & 25.5 \\
\hline HP6-7 & 10.7 & 25.4 \\
\hline HP6-8 & 10.8 & 25.6 \\
\hline \hline Average & $\mathbf{1 0 . 7}$ & $\mathbf{2 5 . 5}$ \\
\hline Std. Dev. & 0.1 & 0.1 \\
\hline
\end{tabular}




\section{APPENDIX-F}

\section{CREEP TEST RESULTS}

Table F-1 Creep Test Results for $100 \%$ Recycled and Blend ABS without Fibers at $\approx 20 \%$ Sustained Loading (Values in Microstrains)

\begin{tabular}{|c|c|c|c|}
\hline Date & Time & A3 & A5 \\
\hline \multirow[t]{8}{*}{$1 / 31 / 11$} & 11:00 AM & 4116 & 3130 \\
\hline & 12:00 PM & 4137 & 3201 \\
\hline & 1:00 PM & 4142 & 3229 \\
\hline & 2:00 PM & 4147 & 3242 \\
\hline & 3:00 PM & 4151 & 3249 \\
\hline & 4:00 PM & 4153 & 3252 \\
\hline & 6:00 PM & 4153 & 3259 \\
\hline & 9:00 PM & 4162 & 3276 \\
\hline \multirow[t]{7}{*}{$2 / 1 / 00$} & $12: 00 \mathrm{AM}$ & 4187 & 3313 \\
\hline & $6: 00$ AM & 4188 & 3313 \\
\hline & 9:00 AM & 4187 & 3314 \\
\hline & 12:00 PM & 4190 & 3315 \\
\hline & 3:00 PM & 4238 & 3362 \\
\hline & 6:00 PM & 4235 & 3362 \\
\hline & 9:00 PM & 4231 & 3361 \\
\hline \multirow[t]{5}{*}{$2 / 2 / 00$} & 12:00 AM & 4242 & 3374 \\
\hline & 6:00 AM & 4232 & 3369 \\
\hline & 9:00 AM & 4230 & 3363 \\
\hline & 3:00 PM & 4190 & 3332 \\
\hline & 9:00 PM & 4253 & 3389 \\
\hline \multirow[t]{6}{*}{ 2/3/00 } & 6:00 AM & 4251 & 3385 \\
\hline & 9:00 AM & 4192 & 3371 \\
\hline & 12:00 PM & 4293 & 3445 \\
\hline & 3:00 PM & 4357 & 3506 \\
\hline & 6:00 PM & 4359 & 3511 \\
\hline & 9:00 PM & 4364 & 3518 \\
\hline \multirow[t]{6}{*}{$2 / 4 / 00$} & 6:00 AM & 4384 & 3530 \\
\hline & 9:00 AM & 4388 & 3533 \\
\hline & 12:00 PM & 4319 & 3479 \\
\hline & 3:00 PM & 4384 & 3545 \\
\hline & 6:00 PM & 4387 & 3545 \\
\hline & 9:00 PM & 4365 & 3517 \\
\hline \multirow[t]{5}{*}{$2 / 5 / 00$} & 6:00 AM & 4372 & 3528 \\
\hline & 9:00 AM & 4374 & 3531 \\
\hline & 12:00 PM & 4369 & 3521 \\
\hline & 6:00 PM & 4406 & 3546 \\
\hline & 9:00 PM & 4402 & 3545 \\
\hline
\end{tabular}




$\begin{array}{llll}2 / 6 / 00 & 9: 00 \mathrm{AM} & 4391 & 3544 \\ & 3: 00 \mathrm{PM} & 4409 & 3569 \\ & 9: 00 \mathrm{PM} & 4417 & 3578 \\ 2 / 7 / 00 & 9: 00 \mathrm{AM} & 4426 & 3586 \\ & 3: 00 \mathrm{PM} & 4465 & 3631 \\ & 9: 00 \mathrm{PM} & 4481 & 3634 \\ 2 / 8 / 00 & 9: 00 \mathrm{AM} & 4451 & 3610 \\ & 3: 00 \mathrm{PM} & 4504 & 3669 \\ & 9: 00 \mathrm{PM} & 4519 & 3675 \\ 2 / 9 / 00 & 9: 00 \mathrm{AM} & 4511 & 3667 \\ & 3: 00 \mathrm{PM} & 4572 & 3718 \\ & 9: 00 \mathrm{PM} & 4568 & 3717 \\ 2 / 10 / 00 & 9: 00 \mathrm{AM} & 4550 & 3709 \\ & 3: 00 \mathrm{PM} & 4604 & 3769 \\ & 9: 00 \mathrm{PM} & 4639 & 3810 \\ 2 / 11 / 00 & 9: 00 \mathrm{AM} & 4654 & 3810 \\ & 3: 00 \mathrm{PM} & 4645 & 3804 \\ & 9: 00 \mathrm{PM} & 4658 & 3810 \\ 2 / 12 / 00 & 9: 00 \mathrm{AM} & 4620 & 3774 \\ & 3: 00 \mathrm{PM} & 4637 & 3796 \\ & 9: 00 \mathrm{PM} & 4662 & 3828 \\ 2 / 13 / 00 & 9: 00 \mathrm{AM} & 4645 & 3805 \\ & 3: 00 \mathrm{PM} & 4696 & 3853 \\ & 9: 00 \mathrm{PM} & 4721 & 3884 \\ 2 / 14 / 00 & 3: 00 \mathrm{PM} & 4761 & 3927 \\ & 9: 00 \mathrm{PM} & 4758 & 3927 \\ 2 / 15 / 00 & 9: 00 \mathrm{AM} & 4758 & 3928 \\ & 9: 00 \mathrm{PM} & 4768 & 3941 \\ 2 / 16 / 00 & 3: 00 \mathrm{PM} & 4782 & 3945 \\ & 9: 00 \mathrm{PM} & 4804 & 3974 \\ 2 / 17 / 00 & 3: 00 \mathrm{PM} & 4885 & 4085 \\ & 9: 00 \mathrm{PM} & 4870 & 4081 \\ 2 / 18 / 00 & 9: 00 \mathrm{PM} & 4874 & 4035 \\ 2 / 19 / 00 & 3: 00 \mathrm{PM} & 4836 & 4006 \\ & 9: 00 \mathrm{PM} & 4849 & 4029 \\ 2 / 20 / 00 & 3: 00 \mathrm{PM} & 4837 & 4002 \\ & 9: 00 \mathrm{PM} & 4827 & 3990 \\ 2 / 21 / 00 & 3: 00 \mathrm{PM} & 4871 & 4045 \\ & 9: 00 \mathrm{PM} & 4897 & 4059 \\ 2 / 22 / 00 & 9: 00 \mathrm{PM} & 4965 & 4145 \\ 2 / 23 / 00 & 9: 00 \mathrm{PM} & 5090 & 4276 \\ 2 / 24 / 00 & 9: 00 \mathrm{PM} & 5182 & 4345 \\ 2 / 25 / 00 & 9: 00 \mathrm{PM} & 5279 & 4431 \\ 2 / 26 / 00 & 9: 00 \mathrm{PM} & 5332 & 4502 \\ 2 / 27 / 00 & 9: 00 \mathrm{PM} & 5370 & 4536 \\ & & & \\ & & \end{array}$




$\begin{array}{cccc}\text { 2/28/00 } & \text { 9:00 PM } & 5335 & 4513 \\ \text { 2/29/00 } & 9: 00 \mathrm{PM} & 5305 & 4478 \\ 3 / 1 / 00 & 9: 00 \mathrm{PM} & 5346 & 4503 \\ 3 / 2 / 00 & 9: 00 \mathrm{PM} & 5305 & 4470 \\ 3 / 3 / 00 & 9: 00 \mathrm{PM} & 5305 & 4469 \\ 3 / 4 / 00 & 9: 00 \mathrm{PM} & 5301 & 4465 \\ 3 / 5 / 00 & 9: 00 \mathrm{PM} & 5302 & 4472 \\ 3 / 6 / 00 & 9: 00 \mathrm{PM} & 5350 & 4529 \\ 3 / 7 / 00 & 9: 00 \mathrm{PM} & 5432 & 4609 \\ 3 / 8 / 00 & 9: 00 \mathrm{PM} & 5630 & 4816 \\ 3 / 9 / 00 & 9: 00 \mathrm{PM} & 5684 & 4864 \\ 3 / 10 / 00 & 9: 00 \mathrm{PM} & 5520 & 4706 \\ 3 / 11 / 00 & 9: 00 \mathrm{PM} & 5555 & 4766 \\ 3 / 12 / 00 & 9: 00 \mathrm{PM} & 5480 & 4630 \\ 3 / 13 / 00 & 9: 00 \mathrm{PM} & 5470 & 4645 \\ 3 / 14 / 00 & 9: 00 \mathrm{PM} & 5465 & 4639 \\ 3 / 15 / 00 & 9: 00 \mathrm{PM} & 5539 & 4718 \\ 3 / 16 / 00 & 9: 00 \mathrm{PM} & 5592 & 4773 \\ 3 / 17 / 00 & 9: 00 \mathrm{PM} & 5491 & 4682 \\ 3 / 18 / 00 & 9: 00 \mathrm{PM} & 5470 & 4651 \\ 3 / 19 / 00 & 9: 00 \mathrm{PM} & 5478 & 4667 \\ 3 / 20 / 00 & 9: 00 \mathrm{PM} & 5516 & 4705 \\ 3 / 21 / 00 & 3: 00 \mathrm{PM} & 5562 & 4739 \\ 3 / 22 / 00 & 3: 00 \mathrm{PM} & 5670 & 4845 \\ 3 / 23 / 00 & 3: 00 \mathrm{PM} & 5773 & 4955 \\ 3 / 24 / 00 & 3: 00 \mathrm{PM} & 5863 & 5052 \\ 3 / 25 / 00 & 3: 00 \mathrm{PM} & 5830 & 5020 \\ 3 / 26 / 00 & 3: 00 \mathrm{PM} & 5743 & 4945 \\ 3 / 27 / 00 & 3: 00 \mathrm{PM} & 5752 & 4950 \\ 3 / 29 / 00 & 3: 00 \mathrm{PM} & 5700 & 4901 \\ 3 / 30 / 00 & 3: 00 \mathrm{PM} & 5694 & 4890 \\ 3 / 31 / 00 & 3: 00 \mathrm{PM} & 5690 & 4885 \\ 4 / 3 / 00 & 3: 00 \mathrm{PM} & 5978 & 5175 \\ 4 / 5 / 00 & 3: 00 \mathrm{PM} & 5896 & 5080 \\ \text { 4/7/00 } & 3: 00 \mathrm{PM} & 5993 & 5168 \\ 4 / 10 / 00 & 3: 00 \mathrm{PM} & 5920 & 5107 \\ 4 / 11 / 00 & 3: 00 \mathrm{PM} & 5902 & 5090 \\ 4 / 13 / 00 & 3: 00 \mathrm{PM} & 5971 & 5195 \\ 4 / 14 / 00 & 3: 00 \mathrm{PM} & 6034 & 5231 \\ 4 / 17 / 00 & 3: 00 \mathrm{PM} & 6082 & 5262 \\ 4 / 18 / 00 & 3: 00 \mathrm{PM} & 6117 & 5295 \\ 4 / 20 / 00 & 3: 00 \mathrm{PM} & 6363 & 5574 \\ 4 / 21 / 00 & 3: 00 \mathrm{PM} & 6432 & 5626 \\ 4 / 24 / 00 & 3: 00 \mathrm{PM} & 6224 & 5407 \\ 4 / 26 / 00 & 3: 00 \mathrm{PM} & 6217 & 5412 \\ 4 / 28 / 00 & 3: 00 \mathrm{PM} & 6256 & 5454\end{array}$




$\begin{array}{cccc}\text { 5/1/00 } & \text { 3:00 PM } & 6365 & 5565 \\ \text { 5/3/00 } & 3: 00 \mathrm{PM} & 6453 & 5640 \\ 5 / 5 / 00 & 3: 00 \mathrm{PM} & 6755 & 5946 \\ 5 / 8 / 00 & 3: 00 \mathrm{PM} & 7072 & 6253 \\ 5 / 10 / 00 & 3: 00 \mathrm{PM} & 6980 & 6130 \\ 5 / 12 / 00 & 3: 00 \mathrm{PM} & 7089 & 6251 \\ 5 / 15 / 00 & 3: 00 \mathrm{PM} & 6800 & 5983 \\ 5 / 17 / 00 & 3: 00 \mathrm{PM} & 6955 & 6122 \\ 5 / 19 / 00 & 3: 00 \mathrm{PM} & 7009 & 6140 \\ 5 / 22 / 00 & 3: 00 \mathrm{PM} & 7030 & 6150 \\ 5 / 26 / 00 & 3: 00 \mathrm{PM} & 7193 & 6316 \\ 5 / 30 / 00 & 3: 00 \mathrm{PM} & 7076 & 6201 \\ 6 / 1 / 00 & 3: 00 \mathrm{PM} & 7579 & 6709 \\ 6 / 2 / 00 & 3: 00 \mathrm{PM} & 7720 & 6845 \\ 6 / 5 / 00 & 3: 00 \mathrm{PM} & 7497 & 6636 \\ 6 / 7 / 00 & 3: 00 \mathrm{PM} & 7346 & 6450 \\ 6 / 9 / 00 & 3: 00 \mathrm{PM} & 7665 & 6829\end{array}$

Table F-2 Creep Test Results for Virgin ABS without Fibers; Virgin, Blend, and $100 \%$ Recycled with Fibers at $\approx 20 \%$ Sustained Loading (Values in Microstrains)

$\begin{array}{cccccc}\text { Date } & \text { Time } & \text { A1 } & \text { A2 } & \text { A4 } & \text { A6 } \\ \text { 2/28/00 } & 11: 30 \text { AM } & & & & \\ & 12: 00 \mathrm{PM} & 3270 & & & 1980 \\ & 12: 30 \mathrm{PM} & 3304 & 2750 & & 2400 \\ & 1: 00 \mathrm{PM} & 3332 & 2777 & & 2411 \\ & 2: 00 \mathrm{PM} & 3364 & 2788 & & 2415 \\ & 3: 00 \mathrm{PM} & 3379 & 2813 & & 2424 \\ & 4: 00 \mathrm{PM} & 3391 & 2826 & & 2426 \\ & 5: 00 \mathrm{PM} & 3397 & 2831 & & 2426 \\ & 7: 00 \mathrm{PM} & 3411 & 2840 & & 2429 \\ & 9: 00 \mathrm{PM} & 3424 & 2841 & & 2432 \\ 2 / 29 / 00 & 12: 00 \mathrm{AM} & 3424 & 2839 & & 2431 \\ & \text { 8:00 AM } & 3430 & 2840 & & 2429 \\ & 11: 00 \mathrm{AM} & 3440 & 2839 & 3400 & 2433 \\ & 12: 00 \mathrm{PM} & & & 3428 & \\ & 1: 00 \mathrm{PM} & 3451 & 2854 & 3432 & 2440 \\ & 2: 00 \mathrm{PM} & & & 3440 & \\ & 3: 00 \mathrm{PM} & 3461 & 2857 & 3442 & 2434 \\ & 4: 00 \mathrm{PM} & & & 3442 & \\ & 5: 00 \mathrm{PM} & 3460 & 2857 & 3441 & 2434 \\ & 7: 00 \mathrm{PM} & 3471 & 2871 & 3453 & 2444 \\ 3 / 1 / 00 & \text { 9:00 PM } & 3481 & 2863 & 3451 & 2443 \\ & 12: 00 \mathrm{AM} & 3472 & 2856 & 3451 & 2442\end{array}$




\begin{tabular}{|c|c|c|c|c|c|}
\hline & 9:00 AM & 3460 & 2847 & 3449 & 2440 \\
\hline & 11:00 AM & 3483 & 2847 & 3456 & 2444 \\
\hline & 1:00 PM & 3512 & 2843 & 3469 & 2454 \\
\hline & 3:00 PM & 3517 & 2842 & 3469 & 2454 \\
\hline & 7:00 PM & 3551 & 2843 & 3482 & 2464 \\
\hline & 9:00 PM & 3556 & 2853 & 3482 & 2467 \\
\hline \multirow[t]{5}{*}{$3 / 2 / 00$} & 9:00 AM & 3549 & 2874 & 3482 & 2467 \\
\hline & 11:00 AM & 3573 & 2881 & 3508 & 2467 \\
\hline & 1:00 PM & 3592 & 2886 & 3508 & 2467 \\
\hline & 3:00 PM & 3592 & 2886 & 3507 & 2466 \\
\hline & 9:00 PM & 3573 & 2888 & 3507 & 2462 \\
\hline \multirow[t]{4}{*}{$3 / 3 / 00$} & 9:00 AM & 3568 & 2886 & 3504 & 2456 \\
\hline & 1:00 PM & 3568 & 2894 & 3506 & 2458 \\
\hline & 5:00 PM & 3584 & 2901 & 3508 & 2460 \\
\hline & 9:00 PM & 3598 & 2905 & 3508 & 2470 \\
\hline \multirow[t]{2}{*}{$3 / 4 / 00$} & 1:00 PM & 3592 & 2901 & 3505 & 2465 \\
\hline & 9:00 PM & 3603 & 2905 & 3512 & 2468 \\
\hline 3/5/00 & 9:00 PM & 3660 & 2918 & 3526 & 2479 \\
\hline $3 / 6 / 00$ & 9:00 PM & 3718 & 2928 & 3540 & 2495 \\
\hline $3 / 7 / 00$ & 9:00 PM & 3816 & 2941 & 3568 & 2521 \\
\hline $3 / 8 / 00$ & 9:00 PM & 4027 & 2990 & 3619 & 2579 \\
\hline $3 / 9 / 00$ & 9:00 PM & 4126 & 3007 & 3649 & 2601 \\
\hline $3 / 10 / 00$ & 9:00 PM & 4002 & 2993 & 3620 & 2564 \\
\hline $3 / 11 / 00$ & 9:00 PM & 4008 & 2981 & 3627 & 2571 \\
\hline $3 / 12 / 00$ & 9:00 PM & 3942 & 2976 & 3607 & 2547 \\
\hline $3 / 13 / 00$ & 9:00 PM & 3942 & 2987 & 3607 & 2550 \\
\hline $3 / 14 / 00$ & 9:00 PM & 3939 & 2987 & 3607 & 2553 \\
\hline $3 / 15 / 00$ & 9:00 PM & 4014 & 2998 & 3629 & 2575 \\
\hline $3 / 16 / 00$ & 9:00 PM & 4078 & 2955 & 3644 & 2594 \\
\hline $3 / 17 / 00$ & 9:00 PM & 4019 & 3008 & 3631 & 2572 \\
\hline $3 / 18 / 00$ & 9:00 PM & 3975 & 3008 & 3623 & 2561 \\
\hline $3 / 19 / 00$ & 9:00 PM & 3995 & 3000 & 3624 & 2568 \\
\hline $3 / 20 / 00$ & 9:00 PM & 4049 & 2991 & 3635 & 2577 \\
\hline $3 / 21 / 00$ & 3:00 PM & 4065 & 2991 & 3645 & 2594 \\
\hline $3 / 22 / 00$ & 3:00 PM & 4173 & 2996 & 3676 & 2617 \\
\hline $3 / 23 / 00$ & 3:00 PM & 4289 & 3043 & 3702 & 2648 \\
\hline $3 / 24 / 00$ & 3:00 PM & 4387 & 3033 & 3730 & 2675 \\
\hline $3 / 25 / 00$ & 3:00 PM & 4383 & 3029 & 3730 & 2670 \\
\hline $3 / 26 / 00$ & 3:00 PM & 4300 & 3000 & 3715 & 2651 \\
\hline $3 / 27 / 00$ & 3:00 PM & 4302 & 3048 & 3713 & 2651 \\
\hline $3 / 29 / 00$ & 3:00 PM & 4300 & 3063 & 3709 & 2650 \\
\hline $3 / 30 / 00$ & 3:00 PM & 4300 & 3078 & 3703 & 2651 \\
\hline $3 / 31 / 00$ & 3:00 PM & 4300 & 3075 & 3702 & 2652 \\
\hline $4 / 3 / 00$ & 3:00 PM & 4527 & 3100 & 3768 & 2715 \\
\hline 4/5/00 & 3:00 PM & 4475 & 3109 & 3760 & 2700 \\
\hline 4/7/00 & 3:00 PM & 4572 & 3045 & 3779 & 2716 \\
\hline
\end{tabular}




$\begin{array}{cccccc}4 / 10 / 00 & 3: 00 \text { PM } & 4501 & 3068 & 3772 & 2705 \\ 4 / 11 / 00 & 3: 00 \text { PM } & 4483 & 3064 & 3760 & 2702 \\ 4 / 13 / 00 & 3: 00 \text { PM } & 4563 & 3076 & 3774 & 2721 \\ 4 / 14 / 00 & 3: 00 \text { PM } & 4640 & 3085 & 3797 & 2734 \\ 4 / 17 / 00 & 3: 00 \text { PM } & 4680 & 3084 & 3824 & 2742 \\ 4 / 18 / 00 & 3: 00 \text { PM } & 4702 & 3084 & 3844 & 2770 \\ 4 / 20 / 00 & 3: 00 \text { PM } & 4990 & 3130 & 3895 & 2827 \\ 4 / 21 / 00 & 3: 00 \text { PM } & 5057 & 3131 & 3909 & 2846 \\ 4 / 24 / 00 & 3: 00 \text { PM } & 4831 & 3122 & 3861 & 2796 \\ 4 / 26 / 00 & 3: 00 \text { PM } & 4859 & 3199 & 3861 & 2798 \\ 4 / 28 / 00 & 3: 00 \text { PM } & 4901 & 3190 & 3867 & 2805 \\ 5 / 1 / 00 & 3: 00 \text { PM } & 5015 & 3203 & 3895 & 2830 \\ 5 / 3 / 00 & 3: 00 \text { PM } & 5116 & 3205 & 3915 & 2850 \\ 5 / 5 / 00 & 3: 00 \text { PM } & 5390 & 3214 & 3990 & 2930 \\ 5 / 8 / 00 & 3: 00 \text { PM } & 5730 & 3325 & 4083 & 3013 \\ 5 / 10 / 00 & 3: 00 \text { PM } & 5652 & 3297 & 4074 & 2983 \\ 5 / 12 / 00 & 3: 00 \text { PM } & 5732 & 3266 & 4081 & 3003 \\ 5 / 15 / 00 & 3: 00 \text { PM } & 5469 & 3312 & 4029 & 2953 \\ 5 / 17 / 00 & 3: 00 \text { PM } & 5596 & 3304 & 4056 & 2975 \\ 5 / 19 / 00 & 3: 00 \text { PM } & 5674 & 3300 & 4085 & 2978 \\ 5 / 22 / 00 & 3: 00 \text { PM } & 5750 & 3315 & 4106 & 3009 \\ 5 / 26 / 00 & 3: 00 \text { PM } & 5910 & 3376 & 4158 & 3048 \\ 5 / 30 / 00 & 3: 00 \text { PM } & 5964 & 3335 & 4140 & 3026 \\ 6 / 1 / 00 & 3: 00 \text { PM } & 6236 & 3409 & 4242 & 3140 \\ 6 / 2 / 00 & 3: 00 \text { PM } & 6379 & 3473 & 4273 & 3170 \\ 6 / 5 / 00 & 3: 00 \text { PM } & 6167 & 3423 & 4221 & 3116 \\ 6 / 7 / 00 & 3: 00 \text { PM } & 6047 & 3418 & 4197 & 3081 \\ 6 / 9 / 00 & 3: 00 \text { PM } & 6361 & 3484 & 4269 & 3160\end{array}$

Table F-3 Creep Test Results for $100 \%$ Recycled and Blend ABS without Fibers at $\approx 50 \%$ Sustained Loading (Values in Microstrains)

$\begin{array}{cccc}\text { Date } & \text { Time } & \text { A3 } & \text { A5 } \\ \text { 2/28/00 } & 10: 30 \mathrm{AM} & 9265 & 8770 \\ & 11: 30 \mathrm{AM} & 9605 & 9497 \\ & 12: 30 \mathrm{PM} & 9801 & 9680 \\ & 1: 00 \mathrm{PM} & 9876 & 9756 \\ & 2: 00 \mathrm{PM} & 10022 & 9896 \\ & 3: 00 \mathrm{PM} & 10166 & 10034 \\ & 4: 00 \mathrm{PM} & 10272 & 10133 \\ & 5: 00 \mathrm{PM} & 10341 & 10183 \\ & \text { 7:00 PM } & 10450 & 10324 \\ & \text { 9:00 PM } & 10623 & 10482 \\ 2 / 29 / 00 & 12: 00 \mathrm{AM} & 10801 & 10651\end{array}$




\begin{tabular}{|c|c|c|c|}
\hline & $8: 00 \mathrm{AM}$ & 11020 & 10871 \\
\hline & $11: 00 \mathrm{AM}$ & 11143 & 10999 \\
\hline & 1:00 PM & 11239 & 11082 \\
\hline & 3:00 PM & 11285 & 1119 \\
\hline & 5:00 PM & 11331 & 11162 \\
\hline & 7:00 PM & 11441 & 11264 \\
\hline & 9:00 PM & 11471 & 11308 \\
\hline \multirow[t]{7}{*}{$3 / 1 / 00$} & $12: 00 \mathrm{AM}$ & 11573 & 11402 \\
\hline & 9:00 AM & 11719 & 11554 \\
\hline & $11: 00 \mathrm{AM}$ & 11758 & 11608 \\
\hline & 1:00 PM & 11877 & 11703 \\
\hline & 3:00 PM & 11882 & 11732 \\
\hline & 7:00 PM & 12014 & 11865 \\
\hline & 9:00 PM & 12048 & 11911 \\
\hline \multirow[t]{5}{*}{$3 / 2 / 00$} & $9: 00 \mathrm{AM}$ & 12146 & 12102 \\
\hline & $11: 00 \mathrm{AM}$ & 12183 & 12143 \\
\hline & 1:00 PM & 12236 & 12189 \\
\hline & 3:00 PM & 12236 & 12189 \\
\hline & 9:00 PM & 12279 & 12260 \\
\hline \multirow[t]{4}{*}{$3 / 3 / 00$} & 9:00 AM & 12401 & 12396 \\
\hline & 1:00 PM & 12458 & 12470 \\
\hline & 5:00 PM & 12548 & 12554 \\
\hline & 9:00 PM & 12584 & 12608 \\
\hline \multirow[t]{2}{*}{$3 / 4 / 00$} & 1:00 PM & 12711 & 12748 \\
\hline & 9:00 PM & 12842 & 12884 \\
\hline $3 / 5 / 00$ & 9:00 PM & 13067 & 13172 \\
\hline \multirow[t]{2}{*}{$3 / 6 / 00$} & $12: 00 \mathrm{PM}$ & 13193 & 13310 \\
\hline & 9:00 PM & 13339 & 13474 \\
\hline \multirow[t]{2}{*}{$3 / 7 / 00$} & 3:00 PM & 13525 & 13670 \\
\hline & 9:00 PM & 13656 & 13821 \\
\hline \multirow[t]{2}{*}{$3 / 8 / 00$} & 2:00 PM & 13926 & 14140 \\
\hline & 9:00 PM & 14117 & 14402 \\
\hline \multirow[t]{2}{*}{$3 / 9 / 00$} & 2:00 PM & 14298 & 14651 \\
\hline & 9:00 PM & 14455 & 14882 \\
\hline \multirow[t]{2}{*}{ 3/10/00 } & 1:00 PM & 14463 & 14955 \\
\hline & 9:00 PM & 14493 & 14979 \\
\hline \multirow[t]{2}{*}{$3 / 11 / 00$} & 1:00 PM & 14568 & 15088 \\
\hline & 9:00 PM & 14688 & 15210 \\
\hline \multirow[t]{2}{*}{ 3/12/00 } & 2:00 PM & 14706 & 15240 \\
\hline & 9:00 PM & 14708 & 15251 \\
\hline \multirow[t]{2}{*}{ 3/13/00 } & 3:00 PM & 14781 & 15352 \\
\hline & 9:00 PM & 14848 & 15413 \\
\hline \multirow[t]{2}{*}{$3 / 14 / 00$} & 3:00 PM & 14849 & 15413 \\
\hline & 9:00 PM & 14967 & 15558 \\
\hline \multirow[t]{2}{*}{$3 / 15 / 00$} & 3:00 PM & 15080 & 15692 \\
\hline & 9:00 PM & 15163 & 15781 \\
\hline
\end{tabular}




$\begin{array}{ccrc}\text { 3/16/00 } & 3: 00 \text { PM } & 15319 & 15922 \\ & 9: 00 \text { PM } & 15367 & 15991 \\ \text { 3/17/00 } & 9: 00 \text { PM } & 15370 & 16025 \\ \text { 3/18/00 } & 9: 00 \text { PM } & 15397 & 16061 \\ \text { 3/19/00 } & 9: 00 \text { PM } & 15506 & 16192 \\ 3 / 20 / 00 & 9: 00 \text { PM } & 15639 & 16350 \\ 3 / 21 / 00 & 3: 00 \text { PM } & 15879 & 16565 \\ \text { 3/22/00 } & 3: 00 \text { PM } & 16085 & 16810 \\ 3 / 23 / 00 & 3: 00 \text { PM } & 16310 & 17069 \\ 3 / 24 / 00 & 3: 00 \text { PM } & 16558 & 17345 \\ 3 / 25 / 00 & 3: 00 \text { PM } & 16666 & 17525 \\ 3 / 26 / 00 & 3: 00 \text { PM } & 16675 & 17541 \\ 3 / 27 / 00 & 3: 00 \text { PM } & 16800 & 17672 \\ 3 / 29 / 00 & 3: 00 \text { PM } & 16891 & 17773 \\ 3 / 30 / 00 & 3: 00 \text { PM } & 16922 & 17821 \\ 3 / 31 / 00 & 3: 00 \text { PM } & 16921 & 17833 \\ 4 / 3 / 00 & 3: 00 \text { PM } & 17540 & 18536 \\ 4 / 5 / 00 & 3: 00 \text { PM } & 17672 & 18764 \\ 4 / 7 / 00 & 3: 00 \text { PM } & 17957 & 19087 \\ & & \text { Failure } & \text { Failure }\end{array}$

Table F-4 Creep Test Results for Virgin ABS without Fibers; Virgin, Blend, and $100 \%$ Recycled with Fibers at $\approx 50 \%$ Sustained Loading (Values in Microstrains)

\begin{tabular}{|c|c|c|c|c|c|}
\hline \multirow{20}{*}{$\begin{array}{c}\text { Date } \\
1 / 11 / 00\end{array}$} & Time & A1 & A2 & A4 & A6 \\
\hline & 9:30 AM & 9490 & & 3759 & 4102 \\
\hline & $10: 00 \mathrm{AM}$ & 9899 & & 3929 & 4265 \\
\hline & $10: 30 \mathrm{AM}$ & 10012 & & 3948 & 4253 \\
\hline & 11:00 AM & 10136 & & 3963 & 4302 \\
\hline & 11:30 AM & 10230 & & 3994 & 4320 \\
\hline & 12:00 PM & 10288 & & 4009 & 4336 \\
\hline & $12: 30 \mathrm{PM}$ & 10379 & & 4023 & 4349 \\
\hline & 1:00 PM & 10418 & & 4032 & 4353 \\
\hline & 2:00 PM & 10493 & & 4035 & 4361 \\
\hline & 2:30 PM & 10510 & & 4050 & 4372 \\
\hline & 3:00 PM & 10559 & & 4060 & 4379 \\
\hline & 3:30 PM & 10610 & & 4068 & 4382 \\
\hline & 4:00 PM & 10612 & & 4069 & 4387 \\
\hline & 4:30 PM & 10667 & & 4081 & 4396 \\
\hline & 5:00 PM & 10740 & & 4073 & 4398 \\
\hline & 5:30 PM & 10754 & & 4081 & 4416 \\
\hline & 6:00 PM & 10807 & & 4098 & 4416 \\
\hline & 8:00 PM & 10924 & & 4122 & 4443 \\
\hline & 10:00 PM & 11024 & & 4140 & 4457 \\
\hline
\end{tabular}




\begin{tabular}{|c|c|c|c|c|c|}
\hline$/ 12 / 00$ & $12: 00$ AM & 11123 & & 4150 & 4471 \\
\hline & $6: 00$ AM & 11352 & & 4177 & 4497 \\
\hline & 8:00 AM & 11432 & & 4205 & 4505 \\
\hline & 9:00 AM & 11469 & & 4215 & 4515 \\
\hline & 10:00 AM & 11492 & & 4223 & 4521 \\
\hline & 11:00 AM & 11528 & & 4228 & 4563 \\
\hline & 12:00 PM & 11580 & & 4228 & 4554 \\
\hline & 1:00 PM & 11640 & & 4236 & 4228 \\
\hline & 2:00 PM & 11661 & 6197 & 4246 & \\
\hline & 3:00 PM & 11698 & 6313 & 4251 & 42 \\
\hline & 4:00 PM & 11745 & 6377 & 4254 & 42 \\
\hline & 5:00 PM & 11760 & 6440 & 4262 & 4232 \\
\hline & 6:00 PM & 11812 & 6461 & 4267 & 4257 \\
\hline & 7:00 PM & 11852 & 6479 & 4274 & 42 \\
\hline & 8:00 PM & 11888 & 6480 & 4279 & 42 \\
\hline & 9:00 PM & 11910 & 6481 & 4283 & 42 \\
\hline & 10:00 PM & 11918 & 6480 & 4285 & 4276 \\
\hline $1 / 13 / 00$ & $12: 00$ AM & 11972 & 6514 & 4293 & 427 \\
\hline & 8:00 AM & 12162 & 6541 & 4309 & 42 \\
\hline & 9:00 AM & 12198 & 6550 & 4312 & \\
\hline & 10:00 AM & 12240 & 6583 & 4318 & 4300 \\
\hline & 11:00 AM & 12260 & 6642 & 4320 & 4304 \\
\hline & $12: 00$ PM & 12293 & 6603 & 4331 & 4308 \\
\hline & 1:00 PM & 12339 & 6668 & 4331 & 4319 \\
\hline & 2:00 PM & 12344 & 6681 & 4337 & 4319 \\
\hline & 4:00 PM & 12361 & 6692 & 4339 & 431 \\
\hline & 6:00 PM & 12386 & 6693 & 4343 & 43 \\
\hline & 8:00 PM & 12428 & 6692 & 4360 & 4337 \\
\hline & 10:00 PM & 12459 & 6695 & 4362 & 43 \\
\hline $1 / 14 / 00$ & $12: 00$ AM & 12483 & 6691 & 4363 & 434 \\
\hline & 6:00 AM & 12516 & 6693 & 4365 & 434 \\
\hline & 10:00 AM & 12548 & 6695 & 4368 & 4345 \\
\hline & 2:00 PM & 12643 & 6693 & 4386 & 4361 \\
\hline & 6:00 PM & 12712 & 6696 & 4395 & 4366 \\
\hline & 10:00 PM & 12739 & 6692 & 4396 & 4370 \\
\hline $1 / 15 / 00$ & $6: 00$ AM & 12778 & 6694 & 4397 & 4372 \\
\hline & 10:00 AM & 12824 & 6698 & 4405 & 437 \\
\hline & 2:00 PM & 12892 & 6713 & 4418 & 4390 \\
\hline & 6:00 PM & 12993 & 6734 & 4437 & 4405 \\
\hline & 10:00 PM & 13065 & 6755 & 4450 & 4418 \\
\hline $1 / 16 / 00$ & $6: 00$ AM & 13171 & 6768 & 4462 & 4428 \\
\hline & 10:00 AM & 13237 & 6779 & 4475 & 444 \\
\hline & 3:00 PM & 13310 & 6797 & 4490 & 445 \\
\hline & 7:00 PM & 13328 & 6800 & 4491 & 445 \\
\hline & 11:00 PM & 13328 & 6800 & 4491 & 445 \\
\hline $1 / 17 / 00$ & 6:00 AM & 13323 & 6790 & 4477 & 443 \\
\hline
\end{tabular}




\begin{tabular}{|c|c|c|c|c|c|}
\hline & $\begin{array}{c}\text { 10:00 AM } \\
\text { 6:00 PM }\end{array}$ & $\begin{array}{l}13335 \\
13527\end{array}$ & $\begin{array}{l}6791 \\
6832\end{array}$ & $\begin{array}{l}4478 \\
4517\end{array}$ & $\begin{array}{l}4442 \\
4477\end{array}$ \\
\hline & 10:00 PM & 13517 & 6832 & 4517 & 4477 \\
\hline \multirow[t]{3}{*}{$1 / 18 / 00$} & 6:00 AM & 13577 & 6838 & 4518 & 4477 \\
\hline & 2:00 PM & 13658 & 6857 & 4536 & 4491 \\
\hline & 10:00 PM & 13789 & 6879 & 4556 & 4513 \\
\hline \multirow[t]{3}{*}{$1 / 19 / 00$} & $6: 00$ AM & 13899 & 6896 & 4573 & 4528 \\
\hline & 2:00 PM & 14015 & 6919 & 4593 & $454 \varepsilon$ \\
\hline & 10:00 PM & 14099 & 6935 & 4607 & 4559 \\
\hline \multirow{3}{*}{$1 / 20 / 00$} & $6: 00$ AM & 14159 & 6946 & 4617 & $456 \varepsilon$ \\
\hline & 2:00 PM & 14237 & 6955 & 4628 & 4578 \\
\hline & 10:00 PM & 14293 & 6965 & 4635 & 458 \\
\hline \multirow[t]{3}{*}{$1 / 21 / 00$} & 6:00 AM & 14308 & 6967 & 4636 & 4581 \\
\hline & 2:00 PM & 14390 & 6978 & 4649 & 4593 \\
\hline & 10:00 PM & 14473 & 6991 & 4660 & 4605 \\
\hline \multirow[t]{3}{*}{$1 / 22 / 00$} & 6:00 AM & 14519 & 6995 & 4666 & 4612 \\
\hline & 2:00 PM & 14599 & 7013 & 4680 & 4623 \\
\hline & 10:00 PM & 14675 & 7025 & 4684 & 4627 \\
\hline \multirow[t]{3}{*}{$1 / 23 / 00$} & 6:00 AM & 14712 & 7031 & 4694 & 4636 \\
\hline & 2:00 PM & 14805 & 7054 & 4715 & 466 \\
\hline & 10:00 PM & 14851 & 7056 & 4723 & 4663 \\
\hline \multirow[t]{3}{*}{$1 / 24 / 00$} & $6: 00$ AM & 14909 & 7067 & 4730 & 4673 \\
\hline & 2:00 PM & 15025 & 7088 & 4747 & 4688 \\
\hline & 10:00 PM & 15040 & 7091 & 4748 & 4689 \\
\hline \multirow[t]{3}{*}{$1 / 25 / 00$} & $6: 00$ AM & 15105 & 7098 & 4758 & 4698 \\
\hline & 2:00 PM & 15045 & 7078 & 4740 & 4680 \\
\hline & 10:00 PM & 15094 & 7090 & 4751 & 4690 \\
\hline \multirow[t]{3}{*}{$1 / 26 / 00$} & 6:00 AM & 15131 & 7096 & 4755 & 4694 \\
\hline & 2:00 PM & 15287 & 7120 & 4777 & 4714 \\
\hline & 10:00 PM & 15266 & 7113 & 4771 & 4707 \\
\hline \multirow{3}{*}{$1 / 27 / 00$} & $6: 00$ AM & 15291 & 7122 & 4777 & 4715 \\
\hline & 2:00 PM & 15329 & 7132 & 4787 & 4720 \\
\hline & 9:00 PM & 15368 & 7132 & 4787 & 4720 \\
\hline \multirow[t]{2}{*}{$1 / 28 / 00$} & 9:00 AM & 15367 & 7124 & 4779 & 471 \\
\hline & 9:00 PM & 15527 & 7157 & 4808 & 4741 \\
\hline \multirow[t]{2}{*}{$1 / 29 / 00$} & 9:00 AM & 15505 & 7150 & 4800 & 473 \\
\hline & 9:00 PM & 15643 & 7176 & 4826 & 475 \\
\hline \multirow[t]{2}{*}{$1 / 30 / 00$} & 9:00 AM & 15749 & 7197 & 4845 & 4775 \\
\hline & 9:00 PM & 15831 & 7211 & 4861 & 478 \\
\hline \multirow[t]{2}{*}{$1 / 31 / 00$} & 9:00 AM & 15889 & 7217 & 4868 & 479 \\
\hline & 9:00 PM & 15986 & 7237 & 4886 & 481 \\
\hline \multirow[t]{2}{*}{ 2/1/00 } & 9:00 AM & 16021 & 7239 & 4891 & 4820 \\
\hline & 9:00 PM & 16093 & 7253 & 4901 & 482 \\
\hline \multirow{2}{*}{$2 / 2 / 00$} & 9:00 AM & 16106 & 7252 & 4899 & 482 \\
\hline & 9:00 PM & 16162 & 7260 & 4909 & 4833 \\
\hline 2/3/00 & 9:00 AM & 16132 & 7240 & 4898 & 481 \\
\hline
\end{tabular}




\begin{tabular}{|c|c|c|c|c|c|}
\hline & 9:00 PM & 16342 & 7295 & 4945 & 486 \\
\hline \multirow[t]{2}{*}{$2 / 4 / 00$} & $9: 00 \mathrm{AM}$ & 16416 & 7307 & 4956 & 487 \\
\hline & 9:00 PM & 16424 & 7306 & 4955 & 487 \\
\hline \multirow[t]{2}{*}{$2 / 5 / 00$} & $9: 00$ AM & 16459 & 7308 & 4959 & 487 \\
\hline & 9:00 PM & 16505 & 7309 & 4960 & $4 \varepsilon$ \\
\hline \multirow[t]{2}{*}{ 2/6/00 } & 9:00 AM & 16538 & 7317 & 4970 & $4 \varepsilon$ \\
\hline & 9:00 PM & 16615 & 7331 & 4983 & 49 \\
\hline \multirow[t]{2}{*}{ 2/7/00 } & 9:00 AM & 16652 & 7337 & 4991 & 49 \\
\hline & 9:00 PM & 16734 & 7355 & 5002 & 48 \\
\hline \multirow[t]{2}{*}{ 2/8/00 } & 9:00 AM & 16748 & 7352 & 5000 & \\
\hline & 9:00 PM & 16860 & 7374 & 5022 & \\
\hline \multirow[t]{2}{*}{ 2/9/00 } & 9:00 AM & 16873 & 7374 & 5022 & 49 \\
\hline & 9:00 PM & 16952 & 7387 & 5039 & \\
\hline \multirow[t]{2}{*}{$2 / 10 / 00$} & 9:00 AM & 17000 & 7392 & 5045 & $4 S$ \\
\hline & 9:00 PM & 17147 & 7423 & 5074 & \\
\hline \multirow[t]{2}{*}{$2 / 11 / 00$} & 9:00 AM & 17200 & 7431 & 5081 & 48 \\
\hline & 9:00 PM & 17273 & 7440 & 5093 & \\
\hline \multirow[t]{2}{*}{$2 / 12 / 00$} & 9:00 AM & 17264 & 7430 & 5083 & 49 \\
\hline & 9:00 PM & 17347 & 7447 & 5101 & 50 \\
\hline \multirow[t]{2}{*}{$2 / 13 / 00$} & $9: 00$ AM & 17350 & 7444 & 5097 & 50 \\
\hline & 9:00 PM & 17484 & 7472 & 5126 & 50 \\
\hline $2 / 14 / 00$ & 9:00 PM & 17624 & 7493 & 5151 & 50 \\
\hline \multirow[t]{2}{*}{$2 / 15 / 00$} & 9:00 AM & 17661 & 7495 & 5151 & 50 \\
\hline & 9:00 PM & 17735 & 7508 & 5163 & 50 \\
\hline 2/16/00 & 9:00 PM & 17845 & 7526 & 5182 & 50 \\
\hline 2/17/00 & 9:00 AM & 17844 & 7521 & 5179 & 50 \\
\hline \multirow[t]{2}{*}{$2 / 18 / 00$} & 9:00 AM & 17945 & 7533 & 5188 & 50 \\
\hline & 9:00 PM & 18075 & 7557 & 5215 & \\
\hline $2 / 19 / 00$ & 9:00 PM & 18158 & 7567 & 5227 & 51 \\
\hline 2/20/00 & 9:00 PM & 18188 & 7561 & 5226 & 51 \\
\hline $2 / 21 / 00$ & 9:00 PM & 18324 & 7587 & 5247 & 51 \\
\hline 2/22/00 & 9:00 PM & 18490 & 7622 & 5283 & 51 \\
\hline $2 / 23 / 00$ & 9:00 PM & 18720 & 7666 & 5328 & 52 \\
\hline $2 / 24 / 00$ & 9:00 PM & 18938 & 7698 & 5363 & 52 \\
\hline 2/25/00 & 9:00 PM & Failure & 7778 & 5433 & 53 \\
\hline $2 / 26 / 00$ & 9:00 PM & & 7821 & 5498 & 537 \\
\hline 2/27/00 & 9:00 PM & & 7826 & 5500 & 537 \\
\hline $2 / 28 / 00$ & 9:00 PM & & 7820 & 5492 & 536 \\
\hline $2 / 29 / 00$ & 9:00 PM & & 7818 & 5493 & 53 \\
\hline $3 / 1 / 00$ & 9:00 PM & & 7838 & 5513 & 53 \\
\hline $3 / 2 / 00$ & 9:00 PM & & 7836 & 5515 & 538 \\
\hline $3 / 3 / 00$ & 9:00 PM & & 7844 & 5517 & 538 \\
\hline $3 / 4 / 00$ & 9:00 PM & & 7846 & 5524 & 539 \\
\hline $3 / 5 / 00$ & 9:00 PM & & 7858 & 5534 & 540 \\
\hline $3 / 6 / 00$ & 9:00 PM & & 7879 & 5559 & 542 \\
\hline $3 / 7 / 00$ & 9:00 PM & & 7909 & 5590 & 54 \\
\hline
\end{tabular}




\begin{tabular}{|c|c|c|c|c|}
\hline $3 / 8 / 00$ & 9:00 PM & 7971 & 5650 & 5513 \\
\hline $3 / 9 / 00$ & 9:00 PM & 8000 & 5687 & 5546 \\
\hline $3 / 10 / 00$ & 9:00 PM & 7976 & 5656 & 5520 \\
\hline $3 / 11 / 00$ & 9:00 PM & 7986 & 5678 & 5533 \\
\hline $3 / 12 / 00$ & 9:00 PM & 7968 & 5657 & 5515 \\
\hline $3 / 13 / 00$ & 9:00 PM & 7974 & 5664 & 5521 \\
\hline $3 / 14 / 00$ & 9:00 PM & 7974 & 5668 & 5520 \\
\hline $3 / 15 / 00$ & 9:00 PM & 8004 & 5695 & 5546 \\
\hline $3 / 16 / 00$ & 9:00 PM & 8029 & 5720 & 5569 \\
\hline $3 / 17 / 00$ & 9:00 PM & 8010 & 5701 & 5550 \\
\hline $3 / 18 / 00$ & 9:00 PM & 8005 & 5696 & 5545 \\
\hline $3 / 19 / 00$ & 9:00 PM & 8015 & 5707 & 5546 \\
\hline $3 / 20 / 00$ & 9:00 PM & 8032 & 5724 & 5573 \\
\hline $3 / 21 / 00$ & 3:00 PM & 8054 & 5751 & 5599 \\
\hline $3 / 22 / 00$ & 3:00 PM & 8086 & 5783 & 5629 \\
\hline $3 / 23 / 00$ & 3:00 PM & 8122 & 5820 & 5663 \\
\hline $3 / 24 / 00$ & 3:00 PM & 8157 & 5854 & 5696 \\
\hline $3 / 25 / 00$ & 3:00 PM & 8155 & 5857 & 5697 \\
\hline $3 / 26 / 00$ & 3:00 PM & 8143 & 5845 & 5683 \\
\hline $3 / 27 / 00$ & 3:00 PM & 8150 & 5856 & 5694 \\
\hline $3 / 29 / 00$ & 3:00 PM & 8147 & 5856 & 5688 \\
\hline $3 / 30 / 00$ & 3:00 PM & 8144 & 5854 & 5686 \\
\hline $3 / 31 / 00$ & 3:00 PM & 8138 & 5849 & 5679 \\
\hline $4 / 3 / 00$ & 3:00 PM & 8246 & 5960 & 5787 \\
\hline $4 / 5 / 00$ & 3:00 PM & 8241 & 5958 & 5782 \\
\hline $4 / 7 / 00$ & 3:00 PM & 8274 & 5994 & 5814 \\
\hline $4 / 10 / 00$ & 3:00 PM & 8277 & 6000 & 5814 \\
\hline $4 / 11 / 00$ & 3:00 PM & 8279 & 6003 & 5814 \\
\hline $4 / 13 / 00$ & 3:00 PM & 8304 & 6038 & 5841 \\
\hline $4 / 14 / 00$ & 3:00 PM & 8327 & 6053 & 5862 \\
\hline $4 / 17 / 00$ & 3:00 PM & 8340 & 6082 & 5896 \\
\hline $4 / 18 / 00$ & 3:00 PM & 8396 & 6136 & 5936 \\
\hline $4 / 20 / 00$ & 3:00 PM & 8480 & 6219 & 6015 \\
\hline $4 / 21 / 00$ & 3:00 PM & 8502 & 6242 & 6038 \\
\hline $4 / 24 / 00$ & 3:00 PM & 8460 & 6207 & 6004 \\
\hline $4 / 26 / 00$ & 3:00 PM & 8472 & 6218 & 6007 \\
\hline $4 / 28 / 00$ & 3:00 PM & 8489 & 6234 & 6024 \\
\hline $5 / 1 / 00$ & 3:00 PM & 8542 & 6278 & 6064 \\
\hline $5 / 3 / 00$ & 3:00 PM & 8564 & 6312 & 6102 \\
\hline $5 / 5 / 00$ & 3:00 PM & 8671 & 6426 & 6209 \\
\hline $5 / 8 / 00$ & 3:00 PM & 8780 & 6558 & 6324 \\
\hline $5 / 10 / 00$ & 3:00 PM & 8790 & 6582 & 6335 \\
\hline $5 / 12 / 00$ & 3:00 PM & 8843 & 6644 & 6390 \\
\hline $5 / 15 / 00$ & 3:00 PM & 8817 & 6637 & 6363 \\
\hline $5 / 17 / 00$ & 3:00 PM & 8857 & 6674 & 6405 \\
\hline $5 / 19 / 00$ & 3:00 PM & 8890 & 6715 & 6443 \\
\hline
\end{tabular}




$\begin{array}{ccccc}\text { 5/22/00 } & \text { 3:00 PM } & 8925 & 6765 & 6480 \\ \text { 5/26/00 } & \text { 3:00 PM } & 8969 & 6809 & 6525 \\ \text { 5/30/00 } & \text { 3:00 PM } & 8962 & 6814 & 6526 \\ \text { 6/1/00 } & \text { 3:00 PM } & 9106 & 6959 & 6661 \\ \text { 6/2/00 } & \text { 3:00 PM } & 9153 & 7009 & 6713 \\ \text { 6/5/00 } & \text { 3:00 PM } & 9124 & 6997 & 6685 \\ \text { 6/7/00 } & \text { 3:00 PM } & 9096 & 6970 & 6658 \\ 6 / 9 / 00 & \text { 3:00 PM } & 9185 & 7065 & 6688\end{array}$

Table F-5 Creep Test Results for Virgin, Blend, and 100\% Recycled PC with and without Fibers at $\approx \mathbf{2 0} \%$ Sustained Loading (Values in Microstrains)

\begin{tabular}{|c|c|c|c|c|c|c|c|}
\hline Date & Time & P1 & P2 & P3 & P4 & P5 & P6 \\
\hline $5 / 25 / 00$ & 11:30 AM & 4151 & & 2980 & & & \\
\hline & 12:30 PM & 4402 & & 3128 & & 4640 & \\
\hline & 1:00 PM & 4430 & & 3151 & 2870 & 4701 & \\
\hline & 2:00 PM & 4480 & & 3176 & 3005 & 4794 & \\
\hline & 3:00 PM & 4538 & 3050 & 3235 & 3012 & 4891 & 2902 \\
\hline & 4:00 PM & 4648 & 3105 & 3325 & 3019 & 4998 & 2953 \\
\hline & 5:00 PM & 4672 & 3116 & 3348 & 3028 & 5028 & 2962 \\
\hline & 6:00 PM & 4740 & 3133 & 3408 & 3042 & 5092 & 2981 \\
\hline & 7:00 PM & 4782 & 3144 & 3444 & 3053 & 5122 & 2991 \\
\hline & 8:00 PM & 4817 & 3151 & 3464 & 3061 & 5150 & 2998 \\
\hline & 9:00 PM & 4855 & 3160 & 3500 & 3069 & 5183 & 3006 \\
\hline & 10:00 PM & 4892 & 3168 & 3529 & 3074 & 5214 & 3014 \\
\hline & 11:00 PM & 4905 & 3172 & 3538 & 3083 & 5228 & 3019 \\
\hline $5 / 26 / 00$ & $12: 00 \mathrm{AM}$ & 4921 & 3176 & 3544 & 3088 & 5232 & 3021 \\
\hline & 6:00 AM & 4955 & 3181 & 3560 & 3093 & 5239 & 3029 \\
\hline & 7:00 AM & 4970 & 3183 & 3567 & 3091 & 5245 & 3035 \\
\hline & 9:00 AM & 4991 & 3168 & 3594 & 3104 & 5278 & 3041 \\
\hline & 10:00 AM & 5030 & 3195 & 3624 & 3106 & 5286 & 3044 \\
\hline & $11: 00$ AM & 5032 & 3199 & 3632 & 3110 & 5305 & 3050 \\
\hline & 12:00 PM & 5049 & 3203 & 3643 & 3115 & 5319 & 3052 \\
\hline & 1:00 PM & 5054 & 3205 & 3646 & 3116 & 5321 & 3052 \\
\hline & 2:00 PM & 5071 & 3208 & 3658 & 3120 & 5338 & 3055 \\
\hline & 3:00 PM & 5086 & 3211 & 3677 & 3121 & 5350 & 3063 \\
\hline & 4:00 PM & 5094 & 3213 & 3683 & 3124 & 5353 & 3062 \\
\hline & 5:00 PM & 5106 & 3213 & 3698 & 3126 & 5367 & 3082 \\
\hline & 6:00 PM & 5130 & 3220 & 3713 & 3130 & 5380 & 3068 \\
\hline & 7:00 PM & 5133 & 3221 & 3713 & 3132 & 5381 & 3068 \\
\hline & 8:00 PM & 5132 & 3223 & 3717 & 3133 & 5380 & 3068 \\
\hline & 9:00 PM & 5133 & 3221 & 3713 & 3132 & 5382 & 3067 \\
\hline & 10:00 PM & 5162 & 3228 & 3742 & 3138 & 5403 & 3076 \\
\hline & 11:00 PM & 5168 & 3228 & 3747 & 3141 & 5402 & 3075 \\
\hline
\end{tabular}




\begin{tabular}{|c|c|c|c|c|c|c|c|}
\hline \multirow[t]{4}{*}{$5 / 27 / 00$} & $12: 00 \mathrm{AM}$ & 5170 & 3230 & 3748 & 3141 & 5408 & 3076 \\
\hline & 12:00 PM & 5260 & 3255 & 3821 & 3167 & 5467 & 3102 \\
\hline & 4:00 PM & 5281 & 3258 & 3834 & 3173 & 5477 & 3107 \\
\hline & 8:00 PM & 5307 & 3265 & 3851 & 3180 & 5487 & 3112 \\
\hline \multirow{4}{*}{$5 / 28 / 00$} & 12:00 AM & 5312 & 3266 & 3857 & 3183 & 5495 & 3116 \\
\hline & 12:00 PM & 5361 & 3281 & 3900 & 3195 & 5524 & 3128 \\
\hline & 4:00 PM & 5386 & 3286 & 3922 & 3203 & 5544 & 3138 \\
\hline & 8:00 PM & 5409 & 3292 & 3945 & 3209 & 5563 & 3143 \\
\hline \multirow[t]{7}{*}{$5 / 29 / 00$} & $12: 00 \mathrm{AM}$ & 5421 & 3295 & 3949 & 3213 & 5569 & 3146 \\
\hline & 6:00 AM & 5416 & 3290 & 3937 & 3208 & 5554 & 3143 \\
\hline & 9:00 AM & 5421 & 3289 & 3938 & 3208 & 5554 & 3143 \\
\hline & 12:00 PM & 5430 & 3295 & 3950 & 3208 & 5560 & 3146 \\
\hline & 3:00 PM & 5453 & 3301 & 3971 & 3213 & 5581 & 3151 \\
\hline & 6:00 PM & 5455 & 3301 & 3983 & 3213 & 5591 & 3150 \\
\hline & 9:00 PM & 5452 & 3301 & 3981 & 3213 & 5592 & 3150 \\
\hline \multirow[t]{6}{*}{$5 / 30 / 00$} & 12:00 AM & 5452 & 3295 & 3955 & 3208 & 5566 & 3145 \\
\hline & $7: 00$ AM & 5415 & 3288 & 3927 & 3201 & 5525 & 3135 \\
\hline & $11: 00$ AM & 5435 & 3300 & 3960 & 3210 & 5558 & 3149 \\
\hline & 3:00 PM & 5444 & 3300 & 3960 & 3210 & 5575 & 3150 \\
\hline & 6:00 PM & 5477 & 3308 & 4000 & 3219 & 5608 & 3156 \\
\hline & 9:00 PM & 5494 & 3311 & 4008 & 3222 & 5610 & 3160 \\
\hline \multirow{4}{*}{$5 / 31 / 00$} & $11: 00 \mathrm{AM}$ & 5508 & 3315 & 4020 & 3230 & 5619 & 3165 \\
\hline & 3:00 PM & 5594 & 3340 & 4105 & 3253 & 5709 & 3187 \\
\hline & 6:00 PM & 5623 & 3349 & 4135 & 3259 & 5735 & 3196 \\
\hline & 9:00 PM & 5650 & 3350 & 4153 & 3268 & 5759 & 3200 \\
\hline \multirow[t]{5}{*}{$6 / 1 / 00$} & 9:00 AM & 5707 & 3367 & 4200 & 3283 & 5788 & 3218 \\
\hline & 12:00 PM & 5756 & 3375 & 4250 & 3296 & 5844 & 3230 \\
\hline & 3:00 PM & 5793 & 3384 & 4297 & 3306 & 5888 & 3237 \\
\hline & 6:00 PM & 5829 & 3389 & 4319 & 3314 & 5915 & 3245 \\
\hline & 9:00 PM & 5864 & 3399 & 4350 & 3324 & 5930 & 3253 \\
\hline \multirow[t]{5}{*}{ 6/2/00 } & 9:00 AM & 5846 & 3399 & 4318 & 3330 & 5932 & 3260 \\
\hline & 12:00 PM & 5942 & 3419 & 4383 & 3340 & 5956 & 3267 \\
\hline & 3:00 PM & 5962 & 3422 & 4443 & 3352 & 6013 & 3278 \\
\hline & 6:00 PM & 6040 & 3426 & 4485 & 3356 & 6033 & 3275 \\
\hline & 9:00 PM & 5942 & 3404 & 4393 & 3352 & 5993 & 3275 \\
\hline \multirow[t]{4}{*}{ 6/3/00 } & 9:00 AM & 5943 & 3407 & 4413 & 3346 & 5992 & 3275 \\
\hline & $12: 00 \mathrm{PM}$ & 5943 & 3412 & 4429 & 3340 & 5992 & 3275 \\
\hline & 3:00 PM & 5946 & 3410 & 4434 & 3356 & 6020 & 3200 \\
\hline & 9:00 PM & 5932 & 3402 & 4407 & 3331 & 5980 & 3260 \\
\hline \multirow[t]{3}{*}{$6 / 4 / 00$} & 12:00 PM & 5903 & 3402 & 4370 & 3325 & 5950 & 3255 \\
\hline & 3:00 PM & 5915 & 3409 & 4396 & 3330 & 5959 & 3262 \\
\hline & 7:00 PM & 5935 & 3412 & 4418 & 3336 & 5978 & 3267 \\
\hline \multirow[t]{4}{*}{$6 / 5 / 00$} & 9:00 AM & 5932 & 3411 & 4403 & 3335 & 5956 & 3265 \\
\hline & 12:00 PM & 5918 & 3409 & 4387 & 3334 & 5946 & 3265 \\
\hline & 3:00 PM & 5960 & 3420 & 4434 & 3345 & 5998 & 3277 \\
\hline & 6:00 PM & 5915 & 3397 & 4363 & 3319 & 5902 & 3248 \\
\hline
\end{tabular}




$\begin{array}{lccccccc} & 9: 00 \mathrm{PM} & 5979 & 3425 & 4442 & 3350 & 6004 & 3280 \\ 6 / 6 / 00 & 9: 00 \mathrm{AM} & 5970 & 3425 & 4437 & 3352 & 5995 & 3281 \\ & 12: 00 \mathrm{PM} & 5969 & 3425 & 4438 & 3350 & 5991 & 3281 \\ 6 / 7 / 00 & 3: 00 \mathrm{PM} & 5960 & 3423 & 4433 & 3349 & 5981 & 3281 \\ & 9: 00 \mathrm{AM} & 5870 & 3401 & 4341 & 3330 & 5886 & 3260 \\ & 12: 00 \mathrm{PM} & 5864 & 3400 & 4342 & 3321 & 5875 & 3257 \\ & 3: 00 \mathrm{PM} & 5885 & 3404 & 4360 & 3327 & 5910 & 3265 \\ & 6: 00 \mathrm{PM} & 5900 & 3406 & 4380 & 3326 & 5925 & 3263 \\ 6 / 8 / 00 & 9: 00 \mathrm{PM} & 5911 & 3408 & 4383 & 3333 & 5939 & 3265 \\ & 9: 00 \mathrm{AM} & 5902 & 3408 & 4372 & 3331 & 5914 & 3263 \\ & 12: 00 \mathrm{PM} & 5925 & 3414 & 4399 & 3336 & 5945 & 3270 \\ & 3: 00 \mathrm{PM} & 5968 & 3426 & 4440 & 3346 & 5994 & 3289 \\ 6 / 9 / 00 & 6: 00 \mathrm{PM} & 5975 & 3427 & 4450 & 3350 & 6002 & 3281 \\ & 9: 00 \mathrm{PM} & 5992 & 3432 & 4468 & 3353 & 6021 & 3286 \\ & 9: 00 \mathrm{AM} & 5902 & 3407 & 4354 & 3336 & 5928 & 3264 \\ & 12: 00 \mathrm{PM} & 5970 & 3429 & 4448 & 3346 & 5979 & 3285 \\ & 3: 00 \mathrm{PM} & 6074 & 3452 & 4549 & 3377 & 6094 & 3305 \\ & 6: 00 \mathrm{PM} & 6077 & 3454 & 4550 & 3380 & 6105 & 3305 \\ 6 / 10 / 00 & 9: 00 \mathrm{PM} & 6095 & 3457 & 4568 & 3382 & 6126 & 3318 \\ & 10: 00 \mathrm{AM} & 6133 & 3467 & 4602 & 3397 & 6147 & 3323 \\ & 3: 00 \mathrm{PM} & 6166 & 3474 & 4642 & 3404 & 6184 & 3333\end{array}$

Table F-6 Creep Test Results for Virgin, Blend, and 100\% Recycled PC with and without Fibers at $\approx \mathbf{5 0 \%}$ Sustained Loading (Values in Microstrains)

$\begin{array}{cccccccc}\text { Date } & \text { Time } & \text { P1 } & \text { P2 } & \text { P3 } & \text { P4 } & \text { P5 } & \text { P6 } \\ \text { 5/25/00 } & \text { 11:30 AM } & & & & & 12503 & \\ & 12: 30 \text { PM } & 11950 & & 12820 & & 13636 & \\ & 2: 00 \text { PM } & 13270 & 7990 & 14380 & 6450 & 14002 & 7520 \\ & 3: 00 \text { PM } & 13540 & 8340 & 14680 & 6725 & 14283 & 7875 \\ & 4: 00 \text { PM } & 13889 & 8488 & 15066 & 6897 & 14649 & 8006 \\ & 5: 00 \text { PM } & 14066 & 8533 & 15386 & 6950 & 14797 & 8056 \\ & 6: 00 \text { PM } & 14285 & 8599 & 15425 & 7027 & 14976 & 8125 \\ \text { 7:00 PM } & 14482 & 8650 & 15601 & 7083 & 15121 & 8175 \\ & \text { 8:00 PM } & 14591 & 8687 & 15725 & 7120 & 15223 & 8210 \\ \text { 9:00 PM } & 14779 & 8736 & 15890 & 7172 & 15371 & 8258 \\ & 10: 00 \text { PM } & 14918 & 8770 & 15999 & 7205 & 15488 & 8291 \\ & 11: 00 \text { PM } & 14997 & 8793 & 16074 & 7229 & 15574 & 8313 \\ \text { 12:00 AM } & 15060 & 8816 & 16160 & 7250 & 15660 & 8335 \\ & 6: 00 \text { AM } & 15497 & 8917 & 16498 & 7368 & 16050 & 8453 \\ & 7: 00 \text { AM } & 15523 & 8927 & 16516 & 7373 & 16075 & 8460 \\ & 9: 00 \text { AM } & 15658 & 8962 & 16642 & 7408 & 16185 & 8483 \\ & 10: 00 \text { AM } & 15703 & 8973 & 16689 & 7420 & 16218 & 8496 \\ & 11: 00 \text { AM } & 15752 & 8985 & 16735 & 7433 & 16259 & 8508\end{array}$




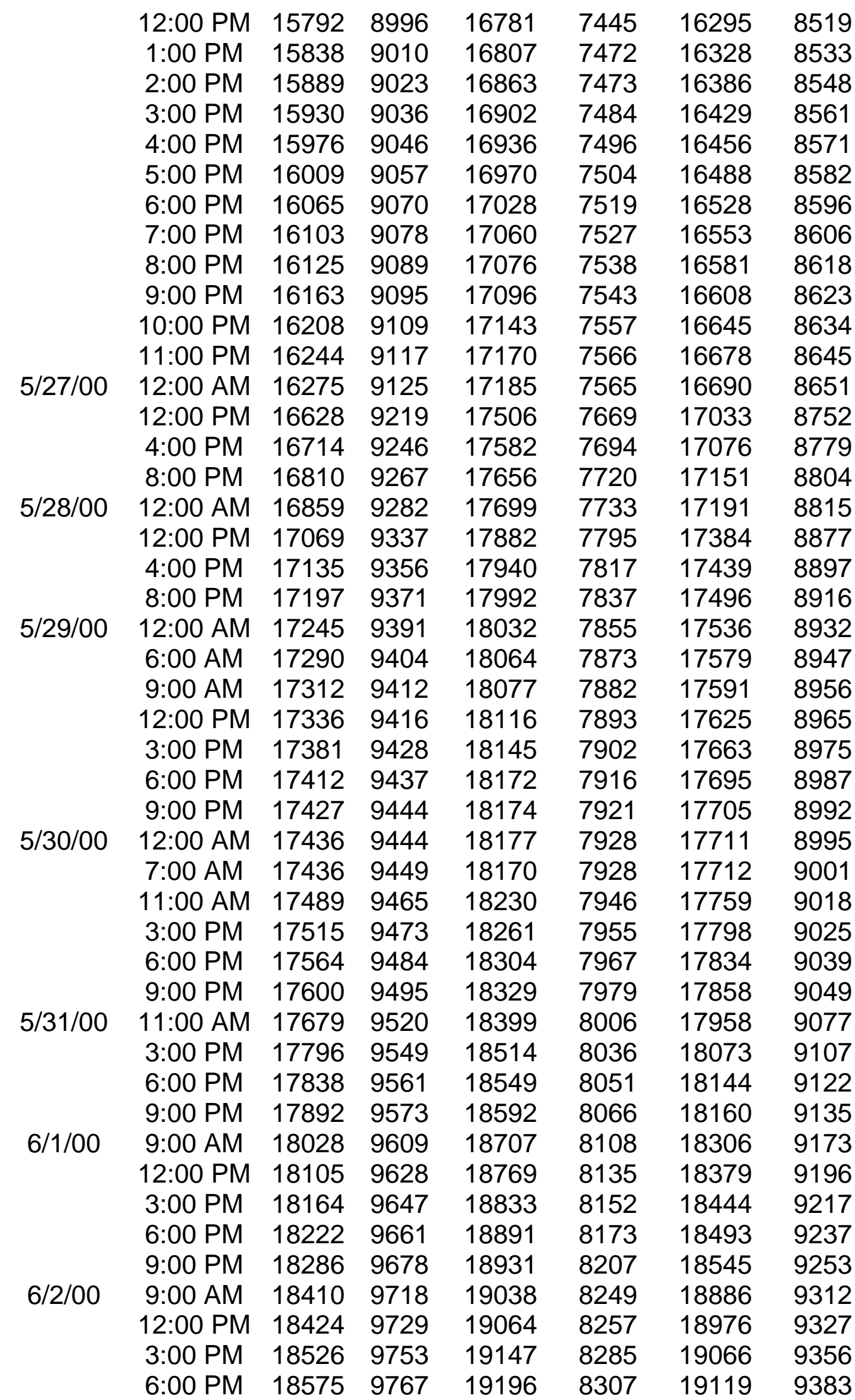




\begin{tabular}{|c|c|c|c|c|c|c|c|}
\hline & 9:00 PM & 18525 & 9750 & 19111 & 8294 & 19053 & 9372 \\
\hline \multirow{4}{*}{$6 / 3 / 00$} & 9:00 AM & 18601 & 9772 & 19184 & 8332 & 19134 & 9409 \\
\hline & 12:00 PM & 18637 & 9793 & 19230 & 8349 & 19177 & \\
\hline & 3:00 PM & 18659 & 9819 & 19241 & 8353 & 19381 & 9402 \\
\hline & 9:00 PM & 18673 & 9810 & 19240 & 8367 & 19399 & 9460 \\
\hline \multirow[t]{3}{*}{$6 / 4 / 00$} & 12:00 PM & 18681 & 9820 & 19249 & 8380 & 19424 & 9476 \\
\hline & 3:00 PM & 18714 & 9833 & 19283 & 8392 & 19465 & 940 \\
\hline & 7:00 PM & 18758 & 9840 & 19320 & 8401 & 19515 & 9500 \\
\hline \multirow[t]{5}{*}{$6 / 5 / 00$} & $9: 00 \mathrm{AM}$ & 18798 & 9853 & 19336 & 8414 & 19551 & 9518 \\
\hline & 12:00 PM & 18796 & 9855 & 19339 & 8419 & 19554 & 9520 \\
\hline & 3:00 PM & 18850 & 9870 & 19394 & 8434 & 24 & 9537 \\
\hline & 6:00 PM & 18848 & 9862 & 19410 & 8436 & 27 & 953 \\
\hline & & 18889 & 9895 & 19431 & 8438 & 19521 & gue \\
\hline \multirow[t]{3}{*}{$6 / 6 / 00$} & 9:00 AM & 18930 & 9895 & 19450 & 8455 & 19689 & 9566 \\
\hline & $12: 0$ & 18931 & 9895 & 19455 & 8463 & & 9570 \\
\hline & 3:0 & 18932 & 9594 & 194 & 8464 & 97 & 9569 \\
\hline \multirow[t]{5}{*}{$6 / 7 / 00$} & 9:00 AM & 18845 & 9885 & 19404 & 8455 & 19650 & 9564 \\
\hline & 12:00 PM & 18883 & 9885 & 19402 & 8456 & 19653 & 9565 \\
\hline & $3: 00$ & 18904 & 9893 & 19430 & 8465 & 19698 & 9573 \\
\hline & 6:00 PM & 18921 & 9896 & 19440 & 8466 & 19712 & 9576 \\
\hline & 9:00 PM & 18940 & 9902 & 19459 & 8470 & 19727 & 9580 \\
\hline \multirow[t]{5}{*}{$6 / 8 / 00$} & $9: 00 \mathrm{AM}$ & 18960 & 9909 & 19460 & 8480 & 19740 & 9594 \\
\hline & 12:00 PM & 18985 & 9916 & 19494 & 8488 & 19769 & 9598 \\
\hline & 3:00 PM & 19032 & 9928 & 195 & 8501 & & 960 \\
\hline & $6: 0$ & 19050 & 9932 & 19554 & 8503 & 19842 & 9613 \\
\hline & 9:00 PM & 19063 & 9936 & 19568 & 8510 & 19859 & 9617 \\
\hline \multirow[t]{5}{*}{$6 / 9 / 00$} & 9:00 AM & 18998 & 9928 & 19486 & 8498 & 19810 & 9605 \\
\hline & 12:00 PM & 19077 & 9946 & 19588 & 8519 & 19875 & 9632 \\
\hline & 3:00 PM & 19189 & 9971 & & 8545 & & 965 \\
\hline & 6:00 PM & 19223 & 9974 & 19693 & 8610 & 20027 & 9659 \\
\hline & 9:00 PM & 19221 & 9979 & 19718 & 8657 & 20032 & 9663 \\
\hline \multirow[t]{2}{*}{$6 / 10 / 00$} & $10: 00$ AM & 19306 & 10004 & 19790 & 8585 & 20113 & 9690 \\
\hline & 3:00 PM & 19345 & 10015 & 19832 & 8601 & 20166 & 970 \\
\hline
\end{tabular}

